

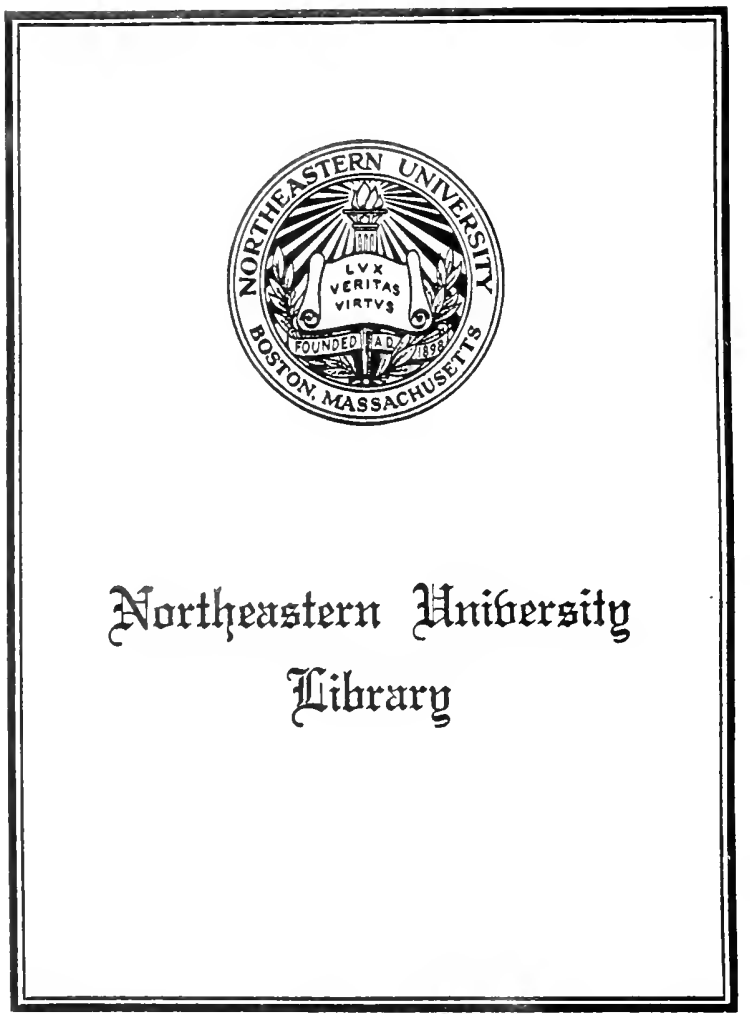




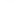




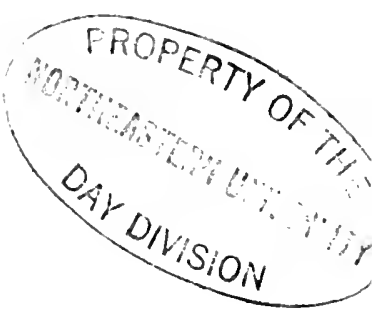

ENGLISH AND AMERICAN TOOL BUILDERS 


$$
\text { . }
$$




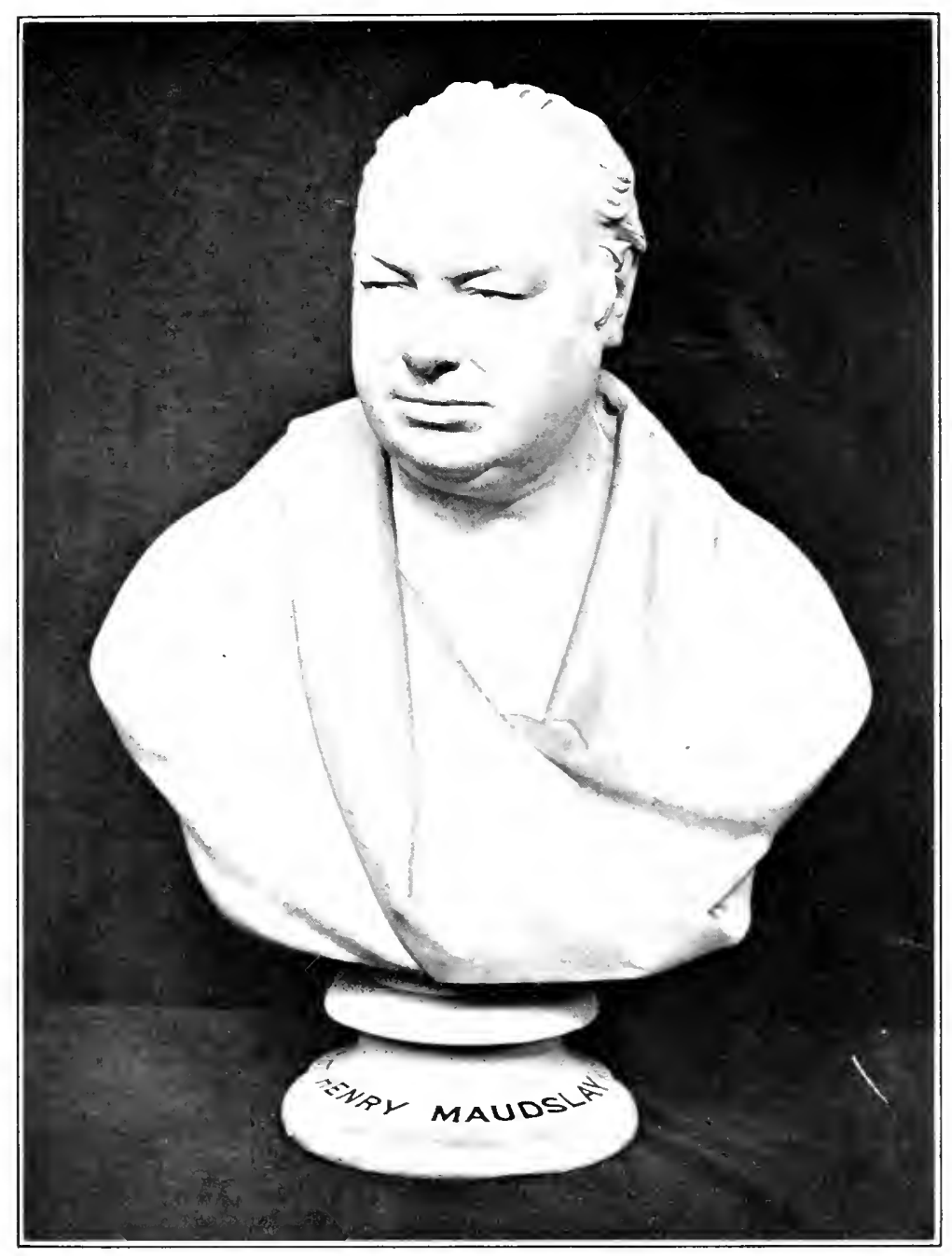

HENRY MATDELAY 


\title{
ENGLISH AND AMERICAN TOOL BUILDERS
}

\author{
$\mathrm{BY}$ \\ JOSEPH WICKHAM ROE \\ Museum of the Peaceful Arts, City of New York, \\ Professor of Industrial Engineering, \\ New York University
}

First Printed in 1916

REPRINTED IN 1926

McGRAW-HILL BOOK COMPANY, INC.

NEW YORK: 370 SEVENTH AVENUE

LONDON: 6 \& 8 BOUVERIE ST., E. C. 4

1926 
COPYright, I9I 6

BY

Joseph Wickham RoE

First published May, I9I6

Republished March, 1926 
"Man is a Tool-using Animal. Weak in himself, and of small stature, he stands on a basis, at most for the flattestsoled, of some half-square foot, insecurely enough; has to straddle out his legs, lest the very wind supplant him. Feeblest of bipeds! Three quintals are a crushing load for him; the steer of the meadow tosses him aloft, like a waste rag. Nevertheless he can use Tools, can devise Tools: with these the granite mountain melts into light dust before him; seas are his smooth highway, winds and fire his unwearying steeds. Nowhere do you find him without Tools; without Tools he is nothing, with Tools he is all."

Carlyle: "Sartor Resartus," Chap. IV. 



\section{PREFACE}

The purpose of this book is to bring out the importance of the work and influence of the great tool builders. Few realize that their art is fundamental to all modern industrial arts. Without machine tools modern machinery could not be built. Little is known by the general public as to who the great tool builders were, and less is known of their lives and work.

History takes good care of soldiers, statesmen and authors. It is even kind to engineers like Watt, Fulton and Stephenson, who have conspicuously and directly affected society at large. But little is known, even among mechanies, of the men whose work was mainly within the engineering profession, and who served other engineers rather than the general public. The lives and the personalities of men like Maudslay, Nasmyth and Eli Whitney, can hardly fail of interest to the mechanic of today. They were busy men and modest, whose records are mainly in iron and steel, and in mechanical devices which are used daily with little thought of their origin.

In following the history of English and American tool builders, the query arises as to whether there might not have been important contributions to tool building from other countries. Others have contributed to some degree, but practically all of the creative work in tool building has been done in these two countries. Although the French were pioneers in many mechanical improvements, they have always shown an aptitude for refinements and ingenious novelties rather than for commercial production on a large scale. They have 
influenced other nations more through their ideas than through their machinery. The Swiss are clever artisans, particularly in fine work, but they have excelled in personal skill, operating on a small scale, rather than in manufacturing. Germany has, under the Empire, developed splendid mechanics, but the principal machine tools had taken shape before 1870 , when the Empire began. The history of English and American tool building, therefore, covers substantially the entire history of the art.

Almost the only book upon tool builders and their work is Samuel Smiles' "Industrial Biography,' which is out of print and little known. It is an admirable and interesting book, and a mine of information upon the English tool builders down to about 1850. The writer has used it freely and would urge those who are interested in the subject to go to it for further information on the early mechanics. It was written, however, over fifty years ago and contains nothing about modern developments or about the American tool builders who have contributed so much.

The writer has tried to trace the origin and rise of tool building in America and to give something of its spread in recent years. The industrial life of the United States is so vast that a comprehensive history of even a single industry, such as tool building, would run far beyond the limits of one volume. This book, therefore, is confined to the main lines of influence in tool building and to the personalities and cities which have been most closely identified with it. The later history of American tool building has never been written. For this the writer has had to rely largely upon personal information from those who are familiar with it, and who have had a part in it. 
Part of the material contained in this book has appeared from time to time in the American Machinist, and the writer would acknowledge his indebtedness most of all to Mr. L. P. Alford, the editor of that journal. His help and counsel have given these pages much of such value as they possess. So many have helped with information, corrections and suggestions that acknowledgments can be made only to a few. The writer would particularly thank Mr. L. D. Burlingame, Mr. Ned Lawrence, Mr. James Hartness, Mr. Coleman Sellers and Mr. Clarence Bement.

If these pages serve to stimulate interest in the lives and work of the tool builders, to whom we owe much, they will fulfill the hope of the writer.

Sheffield Scientific School,

Yale University,

October, 1915.

\section{AUTHOR'S NOTE}

In reprinting this book certain minor corrections have been made. In the later chapters references occur here and there to the "present" condition of various plants and firms. After careful consideration, it seems wise to let these statements stand as they were written in 1915. Interest in this subject centers chiefly on the early history of the plants and firms rather than on recent changes. To revise the statements, bringing them up to date, would add little. With the ever shifting status of a live industry, the statements, so revised, would remain correct for only a short time. Therefore, when a reference is made to present condi- 
tions it should be understood to cover those at the beginning of the World War, which is a natural dividing point in our industrial history.

The general predictions made in the last two paragraphs of the book have been borne out by the developments in American toolbuilding since that time. Museum of the Peaceful Arts,

City of New York, February, 1926. 


\section{TABLE OF CONTENTS}

PAGE

Chapter I. Influence of the Early Tool Builders . 1

Chapter II. Wilkinson and Bramah . . . . . 11

Chapter III. Bentham and Bruncl . . . . . . 22

Chapter IV. Henry Maudslay . . . . . . . 33

Chapter V. Inventors of the Planer . . . . . 50

Chapter VI. Gearing and Millwork . . . . . 63

Chapter VII. Fairbairn and Bodmer . . . . . 71

Chapter VIII. James Nasmyth . . . . . . . 81

Chapter IX. Whitworth . . . . . . . . . 98

Chapter X. Early American Mechanics . . . . 109

Chapter XI. The Rise of Interchangeable Manufacture . . . . . . . . . . 128

Chapter XII. Whitney and North . . . . . 145

Chapter XIII. The Colt Armory . . . . . . . 164

Chapter XIV. The Colt Workman-Pratt \& Whitney 173

Chapter XV. Robbins \& Lawrence . . . . . . 186

Chapter XVI. The Brown \& Sharpe Manufacturing

Company . . . . . . . . 202

Chapter XVII. Central New England . . . . . 216

Chapter XVIII. The Naugatuck Valley . . . . . 231

Chapter XIX. Philadelphia . . . . . . . . 239

Chapter XX. The Western Tool Builders . . . . 261

Appendix A . . . . . . . . . 281

Appendix B, The Jennings Gun . . 292

A Partial Bibliography on Tool Building . . . . . . . 295 



\section{LIST OF ILLUSTRATIONS}

Henry Maudslay

Frontispiece

Fig. 1. Smeaton's Boring Machine, Carron Iron Works, 1769 . . . Facing page 2

Fig. 2. French Lathes of about 1772 . . Facing page 2

Fig. 3. French Slide-Rest, 1772 . . . Facing page 6

Fig. 4. French Lathe for Turning Ovals, 1772 . . . . . . . . Facing page 6

Fig. 5. Genealogy of the Early English Tool Builders . . . . . P page 7

Fig. 6. John Wilkinson . . . . . Facing page 14

Fig. 7. Wilkinson's Boring Machine . Facing page 14

Fig. 8. Eminent Men of Science Living in 1807-8 . . . . . . . Facing page 20

Fig. 9. Sir Samuel Bentham . . . . Facing page 22

Fig. 10. Sir Mare Isambard Brunel . . Facing page 26

Fig. 11. Brunel's Mortising Machine . . Facing page 30

Fig. 12. Brunel's Shaping Machine . . Facing page 30

Fig. 13. French Screw-Cutting Lathe, Previous to 1569 . . . . . page 37

Fig. 14. French Screw-Cutting Lathe, about 1740 . . . . . . page 37

Fig. 15. Maudslay's Screw-Cutting Lathe, about 1797 . . . . . Facing page

Fig. 16. Maudslay's Screw-Cutting Lathe, about 1800 . . . . . Facing page

Fig. 17. French Planing Machine by Nicholas Forq, 1751 . . . Facing page 50

Fig. 18. Matthew Murray . . . . . Facing page 58

Fig. 19. Richard Roberts . . . . . Facing page 58

Fig. 20. Roberts' Planer, Built in 1817 . Facing page 60

Fig. 21. Roberts' Back-Geared Lathe . . Facing page 60

Fig. 22. James Nasmyth . . . . . Facing page 82 
Fig. 23. First Sketch of the Steam Hammer, November 24, 1839

Facing page 94

Fig. 24. Model of the First Steam Hammer

Fig. 25. Sir Joseph Whitworth

Facing page 94

Fig. 26. Samuel Slater Facing page 102 Facing page 122

Fig. 27. Genealogy of the New England Gun Makers .

page 139

Fig. 28. The First Milling Machine, Built by Eli Whitney about 1818

Fig. 29. B l a $\mathrm{n}$ ch ard "Gun-Stocking", Lathe, Built in 1818 for the Springfield Armory . . .

Fig. 30. Eli Whitney . . . . . .

Fig. 31. Samuel Colt

Fig. 32. The Colt Armory .

Fig. 33. Root's Chucking Lathe, about 1855

Facing page

Facing page 142

Facing page 152

Facing page 164

Facing page 168

Facing page 170

Fig. 34. Root's Splining Machine, about 1855

Fig. 35. Francis A. Pratt

Fig. 36. Amos Whitney

Facing page 170

Facing page 178

Facing page 178

Fig. 37. Genealogy of the Robbins \& Lawrence Shop

page 187

Fig. 38. Robbins \& Lawrence Armory, Windsor, Vt.

Facing page 190

Fig. 39. Frederick W. Howe . . . . Facing page 196

Fig. 40. Richard S. Lawrence . . . . Facing page 196

Fig. 41. James Hartness . . . . . Facing page 198

Fig. 42. Joseph R. Brown . . . . . Facing page 202

Fig. 43. First Universal Milling Machine, 1862

Facing page 208

Fig. 44. Early Micrometer Calipers . . Facing page 212

Fig. 45. Genealogy of the Worcester Tool

$$
\text { Builders }
$$

page

223

Fig. 46. Lucius W. Pond . . . . . Facing page 228

Fig. 47. Salmon W. Putnam . . . . Facing page 228 
Fig. 48. Hiram W. Hayden . . . . Facing page 232

Fig. 49. Israel Holmes . . . . . . Facing page 232

Fig. 50. Genealogy of the Naugatuck

Brass Industry . . . . . page 235

Fig. 51. William Sellers . . . . . Facing page 248

Fig. 52. Coleman Sellers ¿. . . . . Facing page 252

Fig. 53. William B. Bement . . . . Facing page 252

Fig. 54. Worcester R. Warner . . . . Facing page 262

Fig. 55. Ambrose Swasey . . . . . Facing page 262

Fig. 56. The "Mult-au-matic" Lathe, 1914 . . . . . . . . Facing page 276

Fig. 57. Machine Tool Building Area of the United States, 1915 . . p page 279 

ENGLISH AND AMERICAN TOOL BUILDERS 


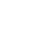




\section{CHAPTER I}

\section{INFLUENCE OF THE EARLY TOOL BUILDERS}

Well-informed persons are aware of the part which machinery in general has had on modern industrial life. But the profound influence which machine tools have had in that development is scarcely realized, even by tool builders themselves.

Three elements came into industrial life during the latter part of the eighteenth century. First, the development of modern banking and the stock company brought out the small private hoards from their hiding places, united them, and made them available for industrial undertakings operating on the scale called for by modern requirements. Second, Watt's development of the steam engine and its application to the production of continuous rotative motion gave the requisite source of power. But neither the steam engine itself nor the machinery of production was possible until the third element, modern machine tools, supplied the means of working metals accurately and economically.

It is well to glance for a moment at the problems which were involved in building the first steam engine. Watt had been working for several years on the steam engine when the idea of the separate condenser came to him on that famous Sunday afternoon walk on the Glasgow Green, in the spring of 1765 , and, to use his own words, "in the course of one or two days the invention was thus far (that is, as a pumping engine) complete in 
my mind." He was a skilled instrument maker and his first small model was fairly successful, but when he undertook "the practice of mechanics in great," his skill and all the skill of those about him was incapable of boring satisfactorily a cylinder 6 inches in diameter and 2 feet long; and he had finally to resort to one which was hammered. For ten weary years he struggled to realize his plans in a full-sized engine, unable to find either the workmen or the tools which could make it a commercial success. His chief difficulty lay in keeping the piston tight. He "wrapped it around with cork, oiled rags, tow, old hats, paper, and other things, but still there were open spaces left, sufficient to let the air in and the steam out."' Small wonder! for we find him complaining that in an 18-inch diameter cylinder, "at the worst place the long diameter exceeded the short by three-eighths of an inch." When Smeaton first saw the engine he reported to the Society of Engineers that "neither the tools nor the workmen existed that could manufacture so complex a machine with sufficient precision.",3

Smeaton himself had designed a boring machine in 1769 for the Carron Iron Works for machining cannon, an illustration of which is given in Fig. 1. ${ }^{4}$ It consisted of a head with inserted cutters mounted on a long, light, overhung boring bar. The work was forced forward on a rude carriage, as shown. The method of supporting the cutter head, indicated in the section, shows an ingenious attempt to obtain a movable support from an inaccurate surface. One need hardly say that the work resulting was inaccurate.

Fortunately, in 1774, John Wilkinson, of Bersham, hit

I Smiles: "Boulton \& Watt," pp. 97, 98. London, 1904.

2 Ibid., p. 114.

3 Ibid., p. 186.

4 "Engineer," London, March 4, 1910; p. 217. Drawn from the description given in Farey's "Treatise on the Steam Engine." 


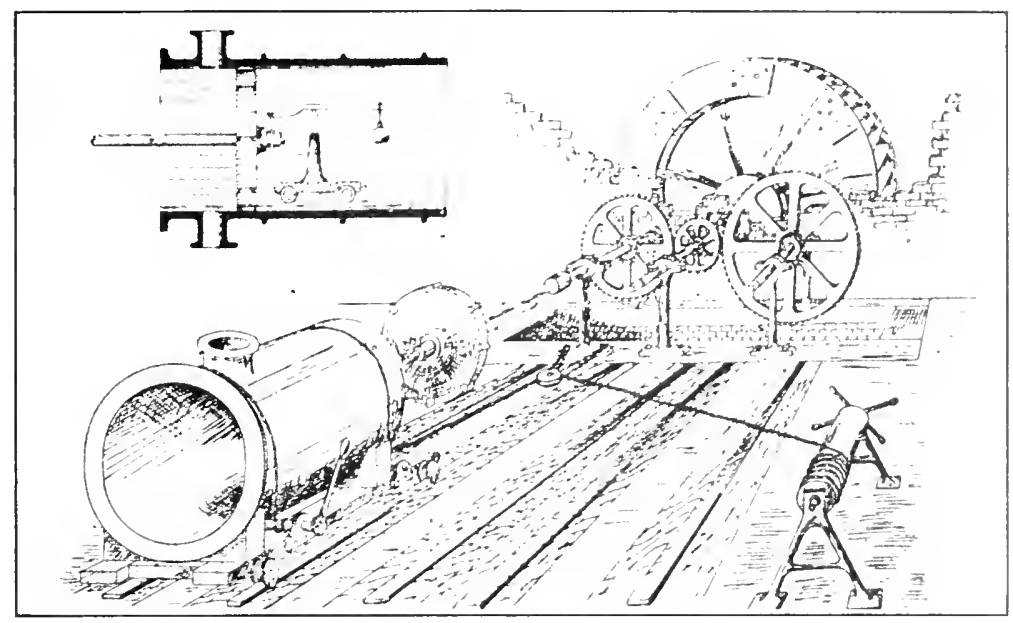

Figure 1. Sueaton's Boring Machine

Carrox Iron Works, 1769

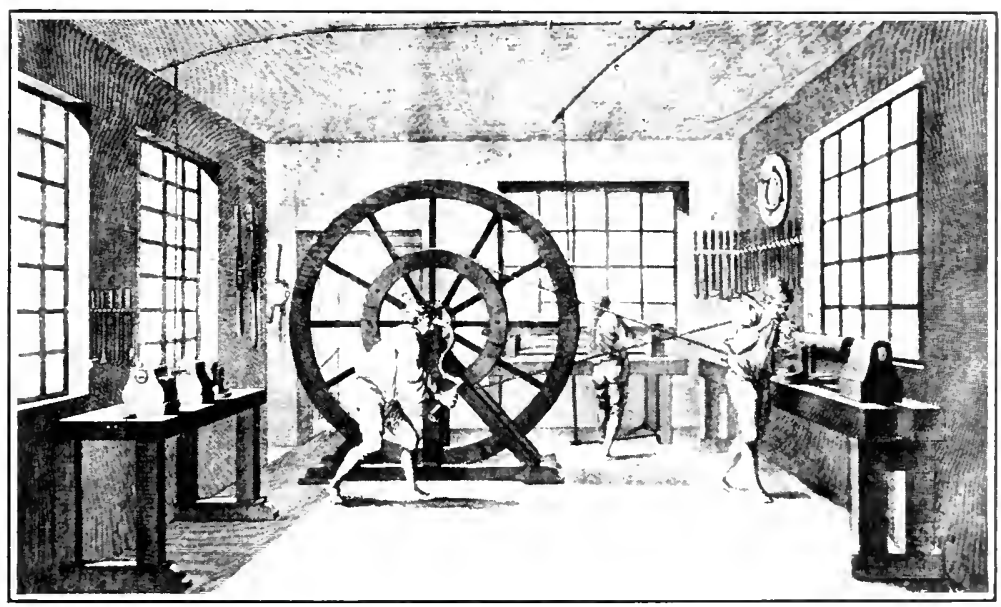

Figure 2. Frexch lathes of abodt $17 \% 2$ 
upon the idea, which had escaped both Smeaton and Watt, of making the boring bar heavier, running it clear through the cylinder and giving it a fixed support at the outboard end as shown in Fig. 7. The superiority of this arrangement was at once manifest, and in 1776 Boulton wrote that "Mr. Wilkinson has bored us several cylinders almost without error; that of 50 inches diameter, which we have put up at Tipton, does not err the thickness of an old shilling in any part." ${ }^{5}$ For a number of years, Wilkinson cast and bored all the cylinders for Boulton \& Watt.

The importance to Boulton \& Watt of the timely aid of Wilkinson's boring machine can hardly be overestimated. It made the steam engine a commercial success, and was probably the first metal-working tool capable of doing large, heavy work with anything like present-day accuracy. ${ }^{\circ}$

We hardly realize the crudity of the tools available in the eighteenth century. In all machinery the principal members were of wood, as that could be worked by the hand tools then in use. The fastenings and smaller parts only were of metal, and consisted of castings and forgings fitted by hand. There were some lathes of the very simplest type. Most of them were "pole" lathes, operated by a cord reaching from a foot treadle, around the work itself, and up to a pole or wooden spring attacked to the ceiling. The work rotated alternately forward and backward, and was caught with a hand tool each time as it came forward. Two are shown in Fig. 2, one at the back and one at the left. Only the very best forms had continuous motion from a direct drive on the

- Farey: “'Treatise on the Steam Engine," p. 328. 1827.

6 Watt's beautiful parallel motion, invented in 1785, was made necessary by the fact that there were no planers to machine a crosshead and guides. Planers were not developed until thirty years later. 
live spindle, as shown at the right of the same figure. This figure is reproduced from the French Dictionnaire des Sciences, published in 1772. Such lathes were almost useless for metal cutting, as they lacked both the necessary power and a holding device strong enough and accurate enough to guide a tool. The slide-rest, while it had been invented, had not been put into practical form or come into general use. There were a few rude drilling and boring machines, but no planing machines, either for metal or wood. The tool equipment of the machinist, or "'millwright," as he was called, consisted chiefly of a hammer, chisel and file. The only measuring devices were calipers and a wooden rule, with occasional reference perhaps to "the thickness of an old shilling," as above. Hand forging was probably as good as or better than that of today. Foundry work had come up to at least the needs of the time. But the appliances for cutting metal were little better than those of the Middle Ages.

Such was the mechanical equipment in 1775 ; practically what it had been for generations. By 1850 it was substantially that of today. In fact, most of this change came in one generation, from about 1800 to 1840 . Since that time there have been many improvements and refinements, but the general principles remain little changed. With so wonderful a transformation in so short a time, several questions arise almost inevitably: Where did this development take place, who brought it about, and why was it so rapid?

The first question is fairly simple. England and America produced the modern machine tool. In the period mentioned, England developed most of the general machine tools of the present day; the boring machine, engine lathe, planer, shaper, the steam hammer and standard taps and dies. Somewhat later, but partially coincident with this, America developed the special 
machine tool, the drop hammer, automatic lathes, the widespread commercial use of limit gauges, and the interchangeable system of manufacture.

In a generalization such as this, the broad lines of influence must be given the chief consideration. Some of the most valuable general tools, such as the universal miller and the grinder, and parts of the standard tools, as the apron in the lathe, are of American origin. But, with all allowances, most of the general machine tools were developed in England and spread from there throughout the world either by utilization of their design or by actual sale. On the other hand, the interchangeable system of manufacture, in a well-developed form, was in operation in England in the manufacture of ships' blocks at Portsmouth shortly after 1800; and yet this block-making machinery had been running for two generations with little or no influence on the general manufacturing of the country, when England, in 1855, imported from America the Enfield gun machinery and adopted what they themselves styled the "American" interchangeable system of gun making. ${ }^{\text {? }}$

The second question as to who brought this change about is not so simple. It is not easy to assign the credit of an invention. Mere priority of suggestion or even of experiment seems hardly sufficient. Nearly every great improvement has been invented independently by a nurnber of men, sometimes almost simultaneously, but often in widely separated times and places. Of these, the man who made it a success is usually found to have united to the element of invention a superior mechanical skill. $\mathrm{He}$ is the one who first embodied the invention in such proportions and mechanical design as to make it commercially available, and from him its permanent influence spreads. The chief credit is due to

7 See page 139. 
him because he impressed it on the world. Some examples may illustrate this point.

Leonardo da Vinci in the fifteenth century anticipated many of the modern tools. ${ }^{8}$ His sketches are fascinating and show a wonderful and fertile ingenuity, but, while we wonder, we smile at their proportions. Had not a later generation of mechanics arisen to re-invent and re-design these tools, mechanical engineering would still be as unknown as when he died.

Take the slide-rest. It is clearly shown in the French encyclopedia of 1772, see Fig. 3, and even in an edition of 1717. Bramah, Bentham and Brunel, in England, and Sylvanus Brown, ${ }^{9}$ in America, are all said to have invented it. David Wilkinson, of Pawtucket, R. I., was granted a patent for it in $1798 .{ }^{10}$ But the invention has been, and will always be, credited to Henry Maudslay, of London. It is right that it should be, for he first designed and built it properly, developed its possibilities, and made it generally useful. The modern slide-rest is a lineal descendant from his.

Blanchard was by no means the first to turn irregular forms on a lathe. The old French rose engine lathe, shown in Fig. 4, embodied the idea, but Blanchard accomplished it in a way more mechanical, of a far wider range of usefulness, and his machine is in general use to this day.

To the third question as to why this development when once begun should have been so rapid, there are probably two answers. First, an entirely new demand for accurate tools arose during these years, springing from the inventions of Arkwright, Whitney, Watt, Fulton, Stephenson and others. The textile industries, the steam engine,

8 American Machinist, Vol. 32, Part 2, pp. 821 and 868.

9Goodrich: "History of Pawtucket,"' pp. 47-48. Pawtucket, 1876.

10 Ibid., p. 51. 


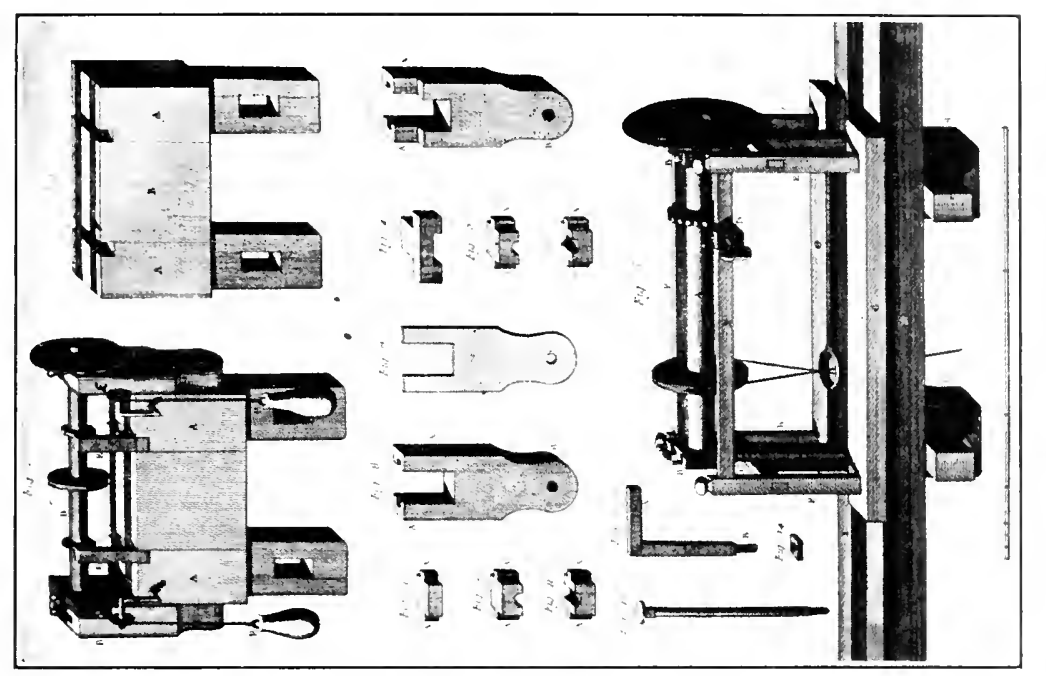

2
2
0

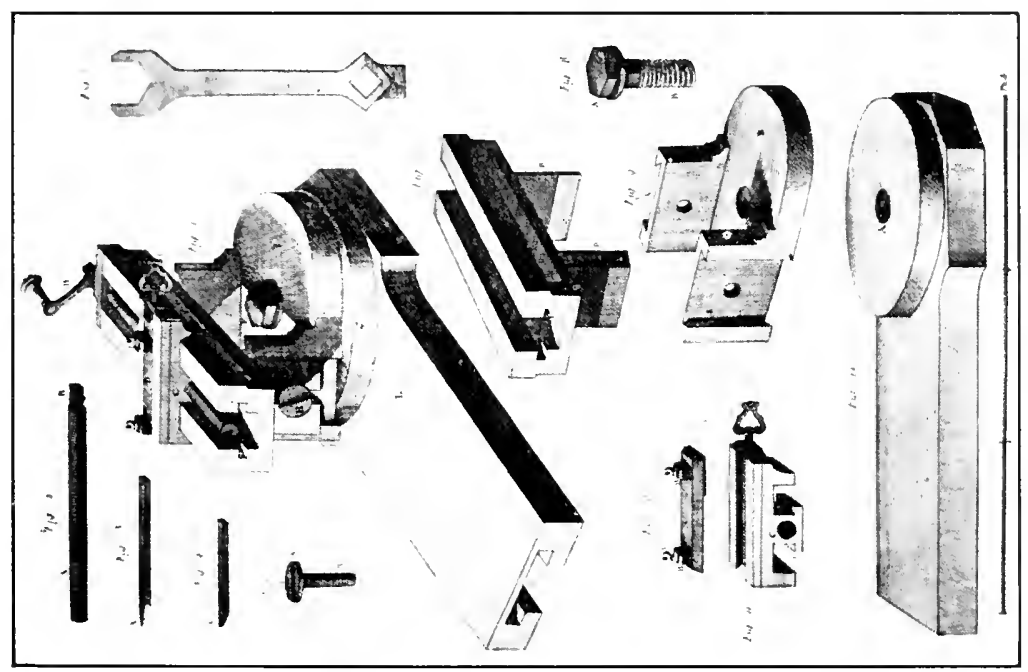

售 


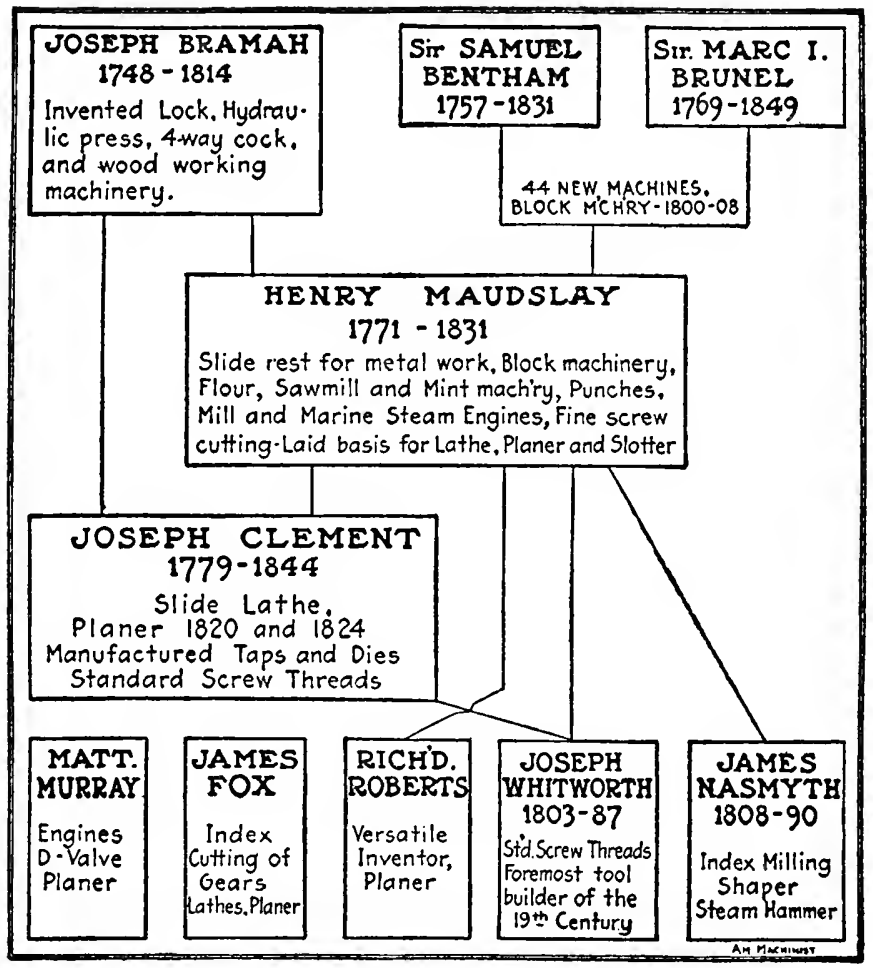

Figdre 5. Genealogy of the Early English Tool Builders 
railways, and the scores of industries they called into being, all called for better and stronger means of production. While the rapidity of the development was due partly to the pressure of this demand, a second element, that of cumulative experience, was present, and can be clearly traced. Wilkinson was somewhat of an exception, as he was primarily an iron master and not a tool builder, so his relationship to other tool builders is not so direct or clear. But the connection between Bramah, Maudslay, Clement, Whitworth and Nasmyth, is shown in the "genealogical" table in Fig. 5.

Bramah had a shop in London where, for many years, he manufactured locks and built hydraulic machinery and woodworking tools. Maudslay, probably the finest mechanician of his day, went to work for Bramah when only eighteen years old and became his foreman in less than a year. He left after a few years and started in for himself, later taking Field into partnership, and Maudslay \& Field's became one of the most famous shops in the world.

Sir Samuel Bentham, who was inspector general of the British navy, began the design of a set of machines for manufacturing pulley blocks at the Portsmouth navy yard. He soon met Marc Isambard Brunel, a brilliant young Royalist officer, who had been driven out of France during the Revolution, and had started working on block machinery through a conversation held at Alexander Hamilton's dinner table while in America a few years before. Bentham saw the superiority of Brunel's plans, substituted them for his own, and commissioned him to go ahead.

In his search for someone to build the machinery, Brunel was referred to Maudslay, then just starting in for himself. Maudslay built the machines, forty-four in all, and they were a brilliant success. There has been 
considerable controversy as to whether Bentham or Brunel designed them. While Maudslay's skill appears in the practical details, the general scheme was undoubtedly Brunel's. In a few of the machines Bentham's designs seem to have been used, but he was able enough and generous enough to set aside most of his own designs for the better ones of Brunel.

Of the earlier tool builders, Maudslay was the greatest. He, more than any other, developed the slide-rest and he laid the basis for the lathe, planer and slotter. His powerful personality is brought out in Nasmyth's autobiography written many years later. Nasmyth was a young boy, eager, with rare mechanical skill and one ambition, to go to London and work for the great Mr. Maudslay. He tells of their meeting, of the interest aroused in the older man, and of his being taken into Maudslay's personal office to work beside him. It is a pleasing picture, the young man and the older one, two of the best mechanics in all England, working side by side, equally proud of each other.

Joseph Clement came to London and worked for Bramah as chief draftsman and as superintendent of his works. After Bramah's death he went to Maudslay's and later went into business for himself. He was an exquisite draftsman, a fertile inventor, and had a very important part in the development of the screw-cutting lathe and planer. Joseph Whitworth, the most influential tool builder of the nineteenth century, worked for Maudslay and for Clement and took up their work at the point where they left off. Under his influence machine tools were given a strength and precision which they had never had before. Richard Roberts was another pupil of Maudslay's whose influence, though important, was not so great as that of the others.

We have an excellent example of what this succession 
meant. Nasmyth tells of the beautiful set of taps and dies which Maudslay made for his own use, and that he standardized the screw-thread practice of his own shop. Clement carried this further. He established a definite number of threads per inch for each size, extended the standardization of threads, and began the regular manufacture of dies and taps. He fluted the taps by means of milling cutters and made them with small shanks, so that they might drop through the tapped hole. Whitworth, taking up Clement's work, standardized the screw threads for all England and brought order out of chaos.

Some account of the growth of machine tools in the hands of these men will be given later. Enough has been said here to show the cumulative effect of their experience, and its part in the industrial advance of the first half of the nineteenth century. Similar successions of American mechanics will be shown later.

Writing from the standpoint of fifty years ago, Smiles quotes Sir William Fairbairn: " "The mechanical operations of the present day could not have been accomplished at any cost thirty years ago; and what was then considered impossible is now performed with an exactitude that never fails to accomplish the end in view.' For this we are mainly indebted to the almost creative power of modern machine tools, and the facilities which they present for the production and reproduction of other machines." "11

11 Smiles: "Industrial Biography," p. 399. 


\section{CHAPTER II \\ WILKINSON AND BRAMAH}

In the previous chapter it was stated that John Wilkinson, of Bersham, made the steam engine commercially possible by first boring Watt's cylinders with the degree of accuracy necessary, and that his boring machine was probably the first metal-cutting tool capable of doing large work with anything like modern accuracy. Although Wilkinson was not primarily a tool builder but an iron master, this achievement alone is sufficient to make him interesting to the tool builders of today.

He was born in 1728. His father made his financial start by manufacturing a crimping iron for ironing the fancy ruffles of the day. John Wilkinson first started a blast furnace at Belston and later joined his father in an iron works the latter had built at Bersham, near Chester. By developing a method of smelting and puddling iron with coal instead of wood-charcoal, he obtained an immense commercial advantage over his rivals and soon became a powerful factor in the iron industry. Later, he built other works, notably one at Broseley, near Coalbrookdale on the Severn.

One of the important branches of his work was the casting and finishing of cannon. It was in connection with this that he invented the boring machine referred to. He bored the first cylinder for Boulton \& Watt in 1775. Farey, in his "History of the Steam Engine," says : 
In the old method, the borer for cutting the metal was not guided in its progress, ${ }^{2}$ and therefore followed the incorrect form given to the cylinder in casting it; it was scarcely insured that every part of the cylinder should be circular; and there was no certainty that the cylinder would be straight. This method was thought sufficient for old engines; but Mr. Watt's engines required greater precision.

Mr. Wilkinson's machine, which is now the common boringmachine, has a straight central bar of great strength, which occupies the central axis of the cylinder, during the operation of boring; and the borer, or cutting instrument, is accurately fitted to slide along this bar, which, being made perfectly straight, serves as a sort of ruler, to give a rectilinear direction to the borer in its progress, so as to produce a cylinder equally straight in the length, and circular in the circumference. This method insures all the accuracy the subject is capable of ; for if the cylinder is cast ever so crooked, the machine will bore it straight and true, provided there is metal enough to form the required cylinder by cutting away the superfluities. ${ }^{2}$

Wilkinson's relations with Boulton \& Watt became very intimate. He showed his confidence in the new engine by ordering the first one built at Soho to blow the bellows of his iron works at Broseley. Great interest was felt in the success of this engine. Other iron manufacturers suspended their building operations to see what the engine could do and Watt himself superintended every detail of its construction and erection. Before it was finished Boulton wrote to Watt:

Pray tell Mr. Wilkinson to get a dozen cylinders cast and bored from 12 to 50 inches in diameter, and as many condensers of suitable sizes; the latter must be sent here, as we will keep them ready fitted up, and then an engine can be turned out of

1 See Fig. 1.

2 Farey: "Treatise on the Steam Engine," p. 326. 1827. 
hand in two or three weeks. I have fixed my mind upon making from 12 to 15 reciprocating, and 50 rotative engines per annum. ${ }^{3}$

This letter is interesting as showing Boulton's clear grasp of the principles of manufacturing. Later, when Boulton \& Watt were hard pressed financially, Wilkinson took a considerable share in their business and when the rotative engine was developed he ordered the first one. He consequently has the honor of being the purchaser of the first reciprocating and the first rotary engine turned out by Watt. Later, when Watt was educating his son to take up his work, he sent him for a year to Wilkinson's iron works at Bersham, to learn their methods.

Fig. 7, taken from an old encyclopedia of manufacturing and engineering, shows the boring machine used for boring Watt's steam cylinders.

On two oaken stringers $S S$, frames $F F$ were mounted which carried a hollow boring bar $A$ driven from the end. The cylinder to be bored was clamped to saddles, as shown. The cutters were carried on a head which rotated with the bar and was fed along it by means of an internal feed-rod and rack. In the machine shown the feeding was done by a weight and lever which actuated a pinion gearing with the rack $R$, but later a positive feed, through a train of gears operated by the main boring-bar, was used. Two roughing cuts and a finishing cut were used, and the average feed is given as $1 / 16$ inch per revolution. While this machine may seem crude, a comparison with Smeaton's boring machine, Fig. 1, will show how great an advance it was over the best which preceded it.

Wilkinson was a pioneer in many lines. He built and 3 Smiles: "Boulton \& Watt," p. 185. London, 1904. 
launched the first iron vessel and in a letter dated July 14,1787 , says :

Yesterday week my iron boat was launched. It answers all my expectations, and has convinced the unbelievers who were 999 in a thousand. It will be only a nine days wonder, and then be like Columbus's egg. ${ }^{*}$

In another letter written a little over a year later, he says :

There have been launched two Iron Vessels in my service since Sept. 1st: one is a canal boat for this [i.e., Birmingham] navigation, the other a barge of 40 tons for the River Severn. The last was floated on Monday and is, I expect, at Stourport with a loading of bar iron. My clerk at Broseley advises me that she swims remarkably light and exceeds my expectations. ${ }^{5}$

In 1788 William Symington built and ran a steamoperated boat on Dalswinton Loch in Scotland, which was a small, light craft with two hulls, made of tinned sheetiron plates. ${ }^{6}$ It has been erroneously claimed that this was the first iron boat. It was at best the second. Although of no commercial importance, it is of very great historical interest as it antedated Fulton's "Clermont" by many years.

Twenty-three years later, in 1810, Onions \& Son of Broseley built the next iron boats, also for use upon the Severn. Five years later Mr. Jervons of Liverpool built a small iron boat for use on the Mersey. In 1821 an iron vessel was built at the Horsley works in Staffordshire, which sailed from London to Havre and went up the Seine to Paris. ${ }^{7}$ Iron vessels were built from time to

4"Beiträge zur Geschichte der Technil und Industrie," 3 Band. S. 227. Berlin, 1911.

- Ibid., 3 Band. S. 227.

- Autobiography of James Nasmyth, p. 30. London, 1883.

7 Smiles: "Men of Invention and Industry," pp. 51-52. New York, 1885 . 


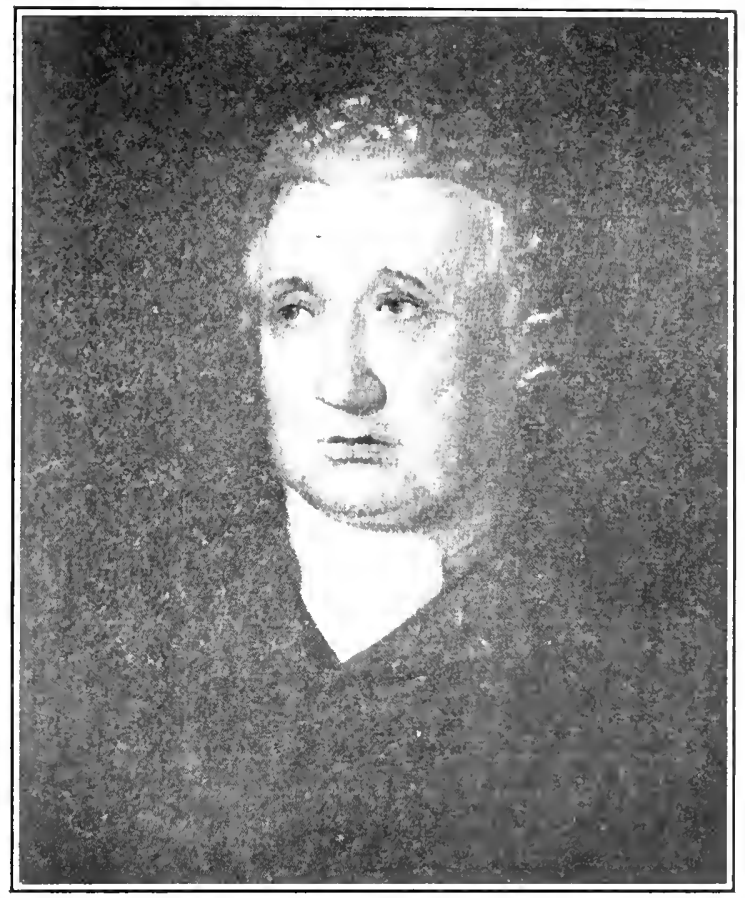

Figure 6. JOHN WILKINSON

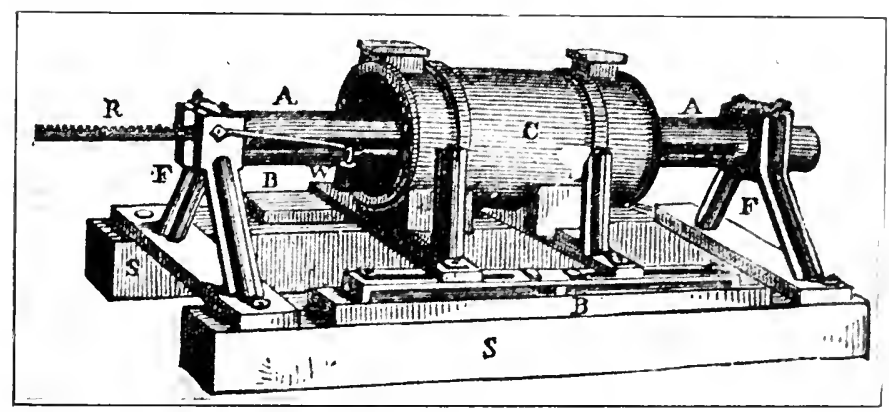

Figure 7. Wilkinson's Borixg Machine

Ĺsed for Machining the Cyliyders of Watt Exgines 
time after that, but it was fully twenty-five years before they came into general use.

With Abraham Darby, 3d, Wilkinson has the honor of having built, in 1779, the first iron bridge, which spanned the Severn at Broseley. This bridge had a span of 100 feet 6 inches, and a clear height of 48 feet, and is standing today as good as ever. ${ }^{8}$ He invented also the method of making continuous lead pipe.

He was a man of great ability, strong and masterful. Boulton wrote of him to Watt:

I can't say but that I admire John Wilkinson for his decisive, clear, and distinct character, which is, I think, a first-rate one of its kind. ${ }^{9}$

There is a note of qualification in the last clause. With all his admirable qualities Wilkinson was not always amiable and he was in constant feud with the other members of his family. He became very wealthy, but his large estate was dissipated in a famous lawsuit between his heirs.

Forceful and able as Wilkinson was, another man, Joseph Bramah, living in London about the same time, had a much more direct influence on tool building. Bramah was a Yorkshire farmer's boy, born in 1748, and lame. ${ }^{10}$ As he could not work on the farm he learned the cabinet maker's trade, went to London, and, in the course of his work which took him into the well-to-do houses about town, he made his first successful invention-the modern water-closet. He patented it in 1778 and 1783 , and it continues to this day in substantially the

8 Smiles: “Industrial Biography," p. 119. Boston, 1864. Also, Beiträge, etc., 3 Band. S. 226.

9 Smiles: “'Boulton \& Watt," p. 438. London, 1904.

10 The best account of Bramah is given in Smiles" "Industrial Biography," pp. 228-244. Boston, 1864. 
same form. In 1784 he patented a lock, which was an improvement on Barron's, invented ten years before, and was one of the most successful ever invented. For many years it had the reputation of being absolutely unpickable. Confident of this, Bramah placed a large padlock on a board in his shop window in Piccadilly and posted beneath it the following notice:

"The artist who can make an instrument that will pick or open this lock shall receive two hundred guineas the moment it is produced.",

Many tried to open it. In one attempt made in 1817 , a elever mechanic named Russell spent a week on it and gave it up in despair. In 1851 Alfred C. Hobbs, an American, mastered it and won the money. He was allowed a month in which to work and the Committee of Referees in their report stated that he spent sixteen days, and an actual working time of fifty-one hours, in doing it. This gave Hobbs a great reputation, which he enhanced by picking every other lock well known in England at that time, and then showing how it was done.

This started up the liveliest kind of a controversy and gave everyone a chance to write to the Times. They all began first picking, then tearing each other's locks. Headlines of "Love (Hobbs?) Laughs at Locksmiths," "Equivocator'" and other like terms appeared."1

It was finally recognized that any lock could be picked by a skillful mechanic with a knowledge of locks, if he were given time enough. The old Bramah lock, made, by the way, by Henry Maudslay himself, did not fare so badly. Hobbs had unmolested access to it for days with any tools he could bring or devise; and though he finally opened it, a lock probably sixty years old which could 11 Price: "Fire and Thief-proof Depositories, and Locks and Keys." 
stand such an assault for fifty hours was secure for all ordinary purposes. ${ }^{12}$

When Bramah began manufacturing the locks he found almost immediately that they called for a better quality of workmanship than was available, with even the best manual skill about him. A series of machine tools had to be devised if they were to be made in the quantities and of the quality desired. He turned first to an old German in Moodie's shop who had the reputation of being the most ingenious workman in London; but while he, with Bramah, saw the need, he could not meet it. One of his shopmates, however, suggested a young man at the Woolwich Arsenal named Henry Maudslay, then only eighteen years old.

Bramah sent for him and Maudslay soon became his right-hand man, and was made superintendent of the works at nineteen. The work of these two men in developing the tools needed laid the foundation for the standard metal-cutting tools of today. The most important improvement was the slide-rest. Nasmyth later said that he had seen the first one, made by Maudslay, running in Bramah's shop and that "in it were all those arrangements which are to be found in the most modern sliderest of our own day" (i.e., fifty years later). Other parts of the metal-cutting lathe also began to take shape; it has been said that parts of the lock were milled on a lathe with rotary cutters, and that the beginnings of the planer were made. How much of this work was Bramah's and how much Maudslay's it would be hard to say. Bramah was a fertile, clever inventor; but Maudslay was

12 Anyone who is interested can find an account of the affair in Price's "Fire and Thief-proof Depositories, and Locks and Keys," published in 1856, and Mr. Hobbs has given his own personal account of it, explaining how the work was done, in the Trans. of the A. S. M. E., Vol. VT, pp. 248253. 
the better general mechanic, had a surer judgment and a greater influence on subsequent tool design.

About this time Bramah invented the hydraulic press. As he first built it, the ram was packed with a stuffingbox and gland. This gripped the ram, retarded the return stroke, and gave him a lot of trouble until Maudslay substituted the self-tightening cup-leather packing for the stuffing-box, an improvement which made the device a success.

Bramah's restless ingenuity was continually at work. He invented a very successful beer-pump in 1797, the four-way cock, a quill sharpener which was in general use until quills were superseded by steel pens, and he dabbled with the steam engine. He was a bitter opponent of Watt and testified against him in the famous suit of Boulton \& Watt against Hornblower. He maintained the superiority of the old Newcomen engines and said that the principle of the separate condenser was fallacious, that Watt had added nothing new which was not worthless, and that his so-called improvements were "monstrous stupidity."

In 1802 Bramah obtained a patent for woodworking machinery second only in importance to that granted Bentham in 1791. Like Bentham, he aimed to replace manual labor "for producing straight, smooth, and parallel surfaces on wood and other materials requiring truth, in a manner much more expeditious and perfect than can be performed by the use of axes, saws, planes, and other cutting instruments used by hand in the ordinary way." His tools were carried in fixed frames and driven by machinery. In his planing machine, one of which was running in the Woolwich Arsenal for fifty years, the cutter-head, which carried twenty-eight tools, was mounted on a vertical shaft and swept across the work in a horizontal plane. He used this same method 
in planing the metal parts for his locks, which corresponds, of course, to our modern face-milling. He provided for cutting spherical and concave surfaces and used his device for making wooden bowls.

In 1806 he devised an automatic machine which the Bank of England used many years in numbering their banknotes, eliminating error and saving the labor of many clerks.

Maudslay was in his employ from 1789 to 1797 . He was getting as superintendent 30 s. (\$7.50) a week. A growing family and "the high cost of living" rendered this insufficient and he applied for more. He was refused so curtly that he gave up his position and started in for himself in a small workshop on Oxford Street in London. Later he took Field in as partner under the firm name of Maudslay \& Field.

In 1813 Bramah engaged another man who later had a great influence, Joseph Clement. Clement soon became his chief draftsman and superintendent. Salaries had gone up somewhat by that time and he had an agreement for five years starting on the basis of three guineas a week with an advance of four shillings each year. At Bramah's death not long after, his sons took charge of the business, and soon grew jealous of Clement's influence. By mutual consent the contract was terminated and he went at once to Maudslay \& Field as their chief draftsman. Later he, too, set up for himself and had an important part in the development of the screw-cutting lathe, the planer and standard screw threads. Whitworth was one of his workmen and Clement's work on taps and dies formed the basis of the Whitworth thread.

Bramah died in 1814, at the age of sixty-six. He was a man of widely recognized influence, a keen and independent thinker, a good talker, and, though it might not appear from what has been said, a cheery and always 
welcome companion. He left a reputation for absolute business integrity and the quality of his workmanship was unrivaled until his later years, when he was equaled only by those he had himself trained. He gave the world some great and valuable devices and paved the way for others. His influence on modern tools can probably never be accurately judged, but Smiles' tribute to him is as true today as when it was written, two generations ago :

From his shops at Pimlico came Henry Maudslay, Joseph Clement, and many more first-class mechanics, who carried the mechanical arts to still higher perfection, and gave an impulse to mechanical engineering the effects of which are still felt in every branch of industry. ${ }^{13}$

Bramah had an invincible dislike for sitting for his portrait and consequently none exists. A death-mask was made by Sir Francis Chantrey, who executed the Watt statue in Westminster Abbey, but it was unfortunately destroyed by Lady Chantrey. The complete cata$\log$ of the National Portrait Gallery in London ${ }^{14}$ gives Bramah's name. The reference, however, directs one to Walker's famous engraving of the "Eminent Men of Science Living in 1807-1808,"' which shows about fifty distinguished scientists and engineers grouped in the Library of the Royal Institution. This engraving is the result of four years' careful study. It was grouped by Sir John Gilbert, drawn by John Skill, and finished by William Walker and his wife. Bramah's figure, No. 6, appears in this group, but with his back turned, the only one in that position. It is a singular tribute to Bramah's influence among his generation of scientists that this picture would have been considered incomplete without him.

13 Smiles: "Industrial Biography," p. 244.

14 Cust's. 


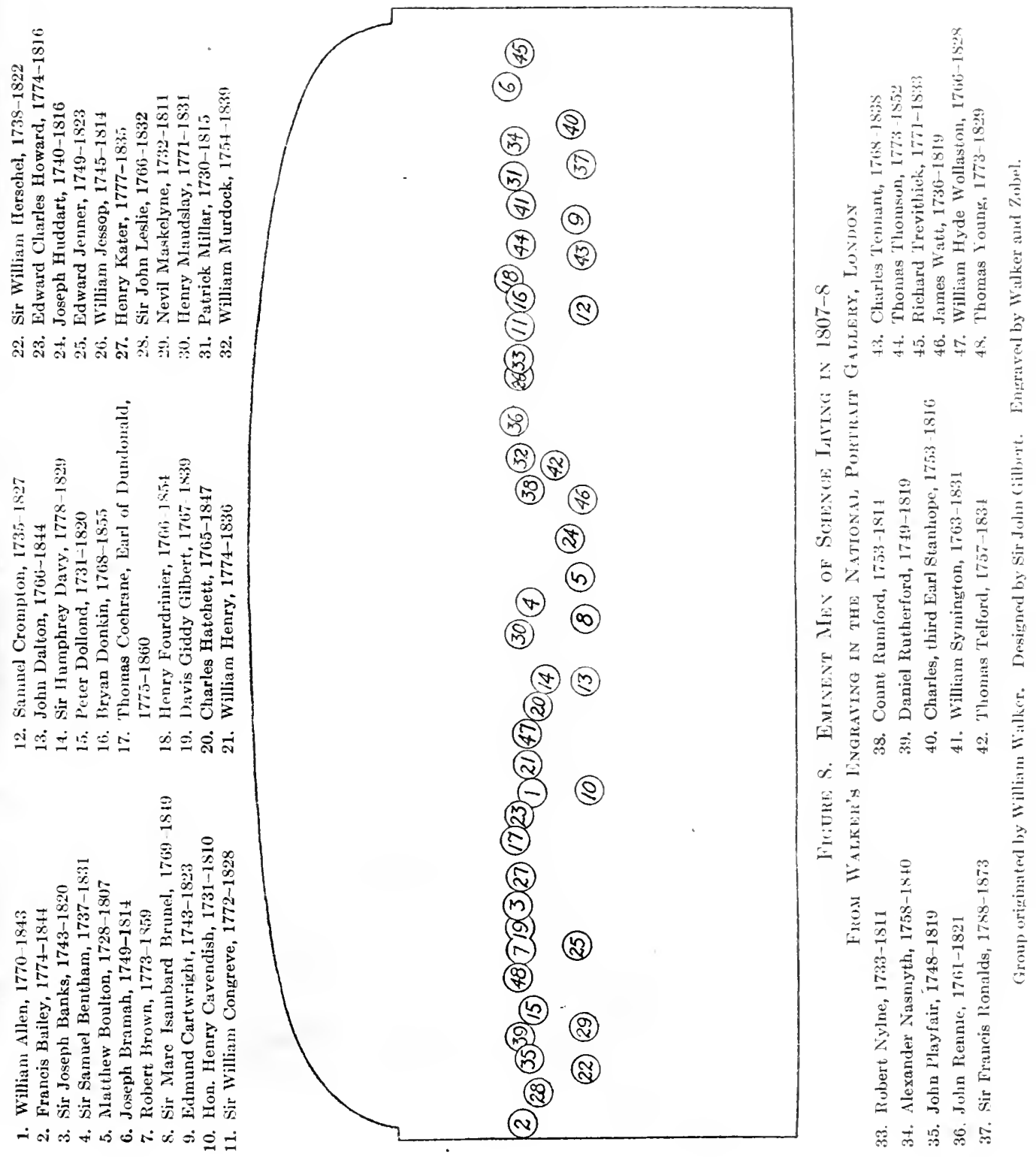




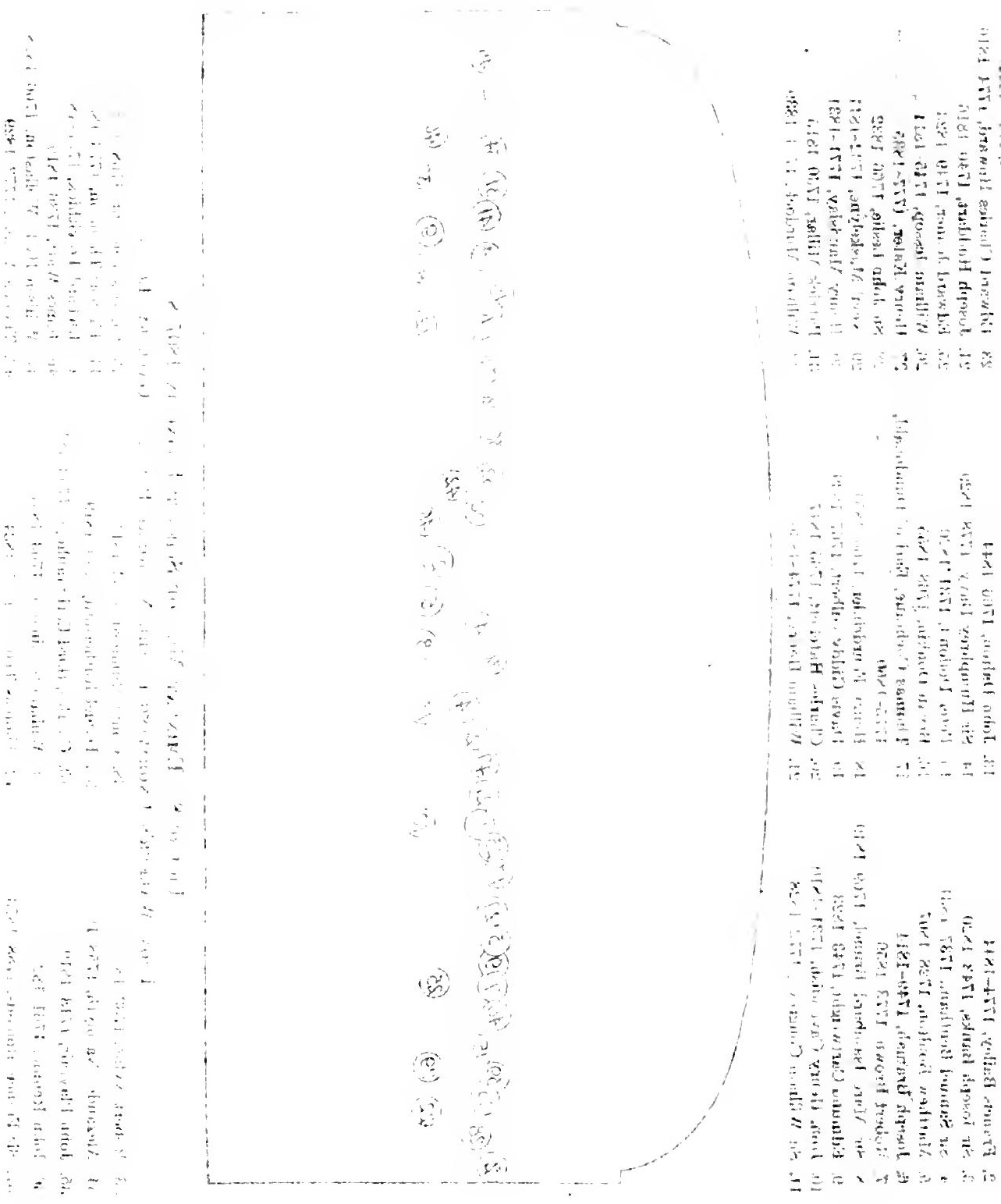




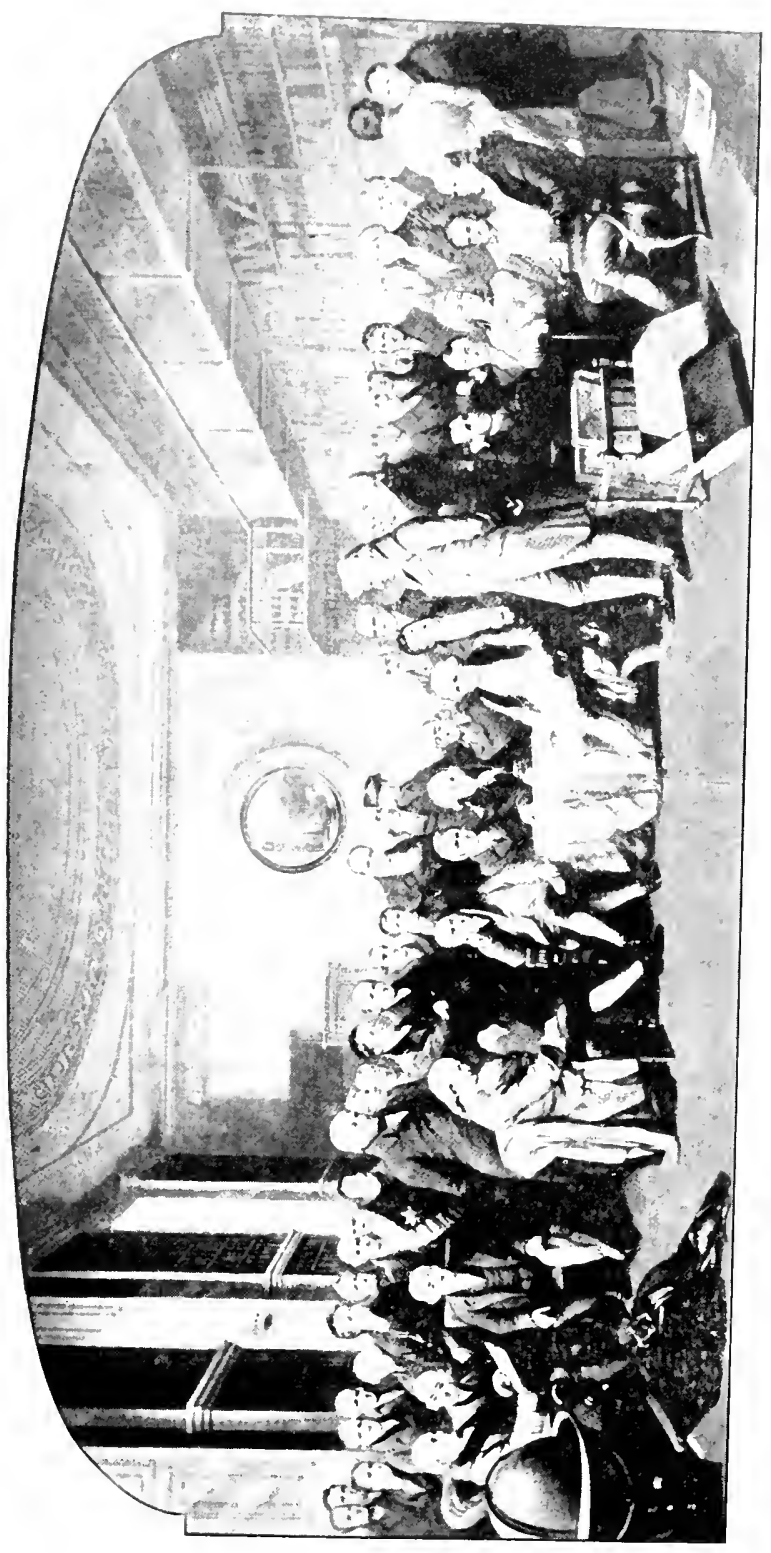



As no portrait of him existed he was included, but with his face turned away. The figure was drawn in accordance with a description furnished by Bramah's grandson, E. H. Bramah.

The engraving includes many other men of interest whose names are indicated. Some of them have already been considered; others, while famous as engineers, worked in fields other than the one we are considering. 


\section{CHAPTER III \\ BENTHAM AND BRUNEL}

In the genealogical table shown in Fig. 5, Sir Samuel Bentham and Sir Marc I. Brunel are indicated as having originated the famous "Portsmouth Block Machinery," which was built by Maudslay and which first gave him his reputation as a tool builder. While Bentham was primarily a naval administrator and Brunel a civil engineer, they were among the first to grasp the principles of modern manufacturing and embody them successfully. Both were men of distinction and each had an interesting career.

Samuel Bentham, Fig. 9, was a brother of Jeremy Bentham, the famous English publicist and writer on economics, and a step-brother of Charles Abbott, speaker of the House of Commons. He was born in 1757, went to the Westminster School, and later was a naval apprentice in the Woolwich Arsenal. His tastes and his training led him toward the administrative and constructive work of the navy, and for this he had the best education available at that time. He went to sea after a final year at the Naval College at Portsmouth; and in 1780, in consequence of his abilities, was sent by Earl Howe, then first Lord of the Admiralty, to visit the various ports of northern Europe. He went through the great ports of Holland and the Baltic, eastward to St. Petersburg, and was introduced at the Russian court by the British ambassador.

The Russians took to him kindly, as he was handsome, 


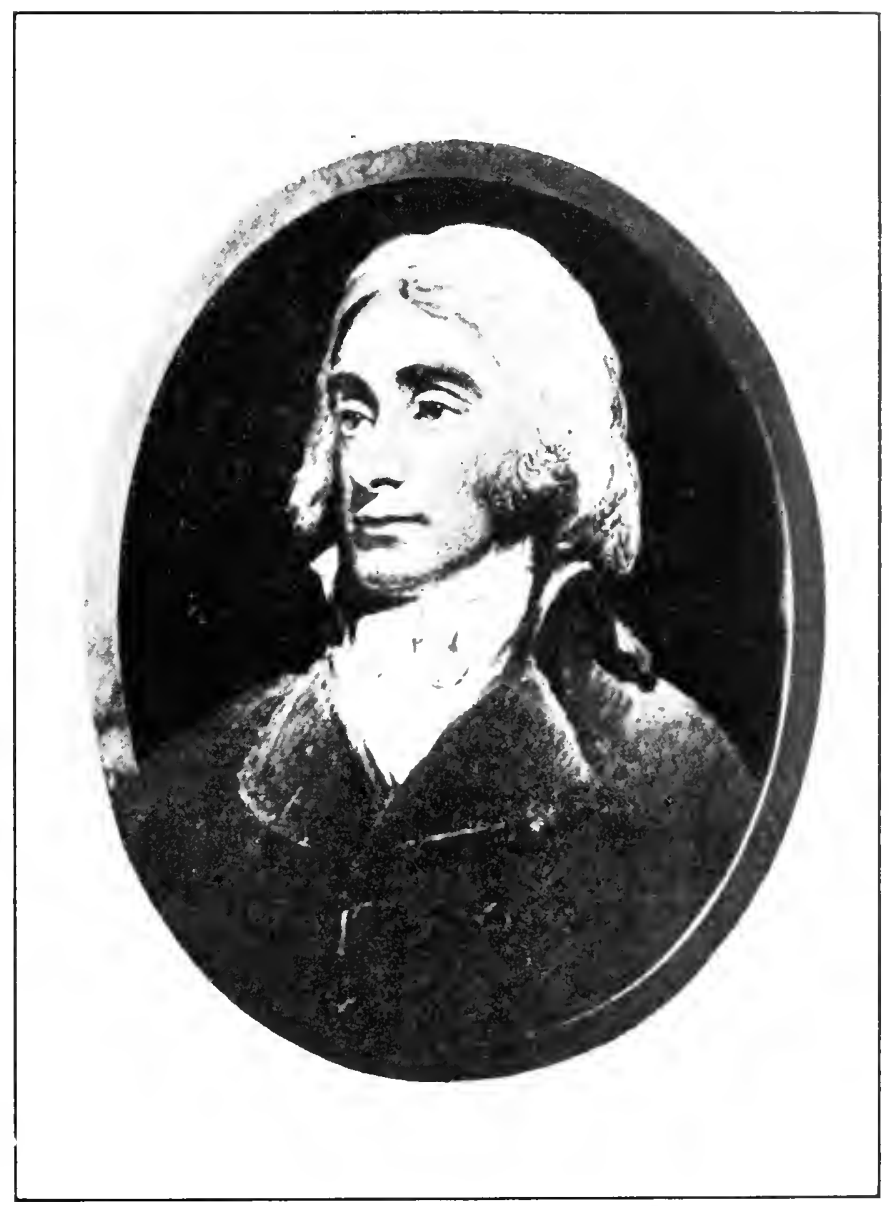

Figure 9, Sir Samuel Bentham From an Old Miniatere 
tall, and distinguished in manner, inspired confidence, and made and held friends. He was well received by the Empress Catherine, and soon became a favorite of Prince Potemkin. He traveled over a greater part of the empire from the Black Sea to the Arctic and as far east as China, examining mining and engineering works. On his return to St. Petersburg he fell in love with a wealthy heiress of the nobility. The parents objected; but though the empress, who was interested, advised an elopement, he gave it up as dishonorable and went away to Critcheff in southern Russia as a lieutenant-colonel of engineers in the Russian army. While there be took charge of Potemkin's grossly mismanaged factories in order to put them on a sound basis, an undertaking suggestive of the twentieth-century efficiency engineer. In this he was not wholly successful. In 1787 he built and equipped a flotilla of ships, and in the following year distinguished himself in a naval battle with the Turks, in which John Paul Jones was also engaged. One of the vital elements in the fight was the use of the large guns built by Bentham, which fired shells for the first time in naval warfare. Nine Turkish ships were burned or sunk and 8000 men were killed or taken prisoners. For his part in this battle Bentham was knighted and made a brigadier-general.

There were few skilled artisans in Russia and almost none available in the southern provinces-a Danish brass founder, an English watchmaker and two or three sergeants who could write and draw were all he had. This set Bentham at work on the problem of "transferring skill" by means of machines, so that unskilled workmen might be made to produce the same results as skilled labor.

While Bramah and Maudslay were working in Lon- 
don on their metal-cutting tools for making locks, Bentham, in Russia, was thinking out substantially the same problem in woodworking machinery. He returned to England in 1791 and that year took out his first patent. Certain suggestions which he made to the Admiralty about the introduction of machinery into the dockyards led to his making an extended inspection of the dockyards throughout the kingdom, and he reported that immense savings were possible. The office of inspector general was created for him and authority given him to put his recommendations into effect.

For the next eighteen years he served the British navy. When he took hold it was honeycombed with inefficiency and worse. His business-like methods, his skill as an engineer and naval designer, and his fearless integrity were elements in the preparedness of the British navy in the Napoleonic wars. He was an intrepid enemy of red tape and graft and soon made cordial enemies; but he was a good fighter, with no weak spots in his armor, and it took many years to bring him down. In 1805 he was sent to St. Petersburg, and kept there on various pretexts for two years. It was remarked by some about the Admiralty office, that so high was their opinion of his talents they would be glad to give him $£ 6000$ ( $\$ 30$,000) a year if by that means they would never see him again. He returned in 1807 to find his office abolished and its functions transferred to a board, of which he was made a member at an increased salary. Here his power was diluted somewhat, but even this solution was too strong and he was retired on a pension in 1812. For the next fifteen years he lived in retirement in France. The years abroad softened the rancor of his enemies and from his return to England in 1827 until his death, Bentham was in frequent and friendly consultation with the 
navy officials. Bentham may well be considered as one of the first and greatest of "efficiency experts."

The patent of 1791 referred to is not important, but it was followed by another in 1793 in which was set forth the whole scheme of woodworking machinery which had been maturing in Bentham's mind. This has been characterized as one of the most remarkable patents ever issued by the British Patent Office. More than fifty years after, one of the Crown judges said of it in summing up a case before him involving woodworking machinery, that "the specification of his (i.e., Bentham's) patent of 1793 is a perfect treatise on the subject; indeed, the only one worth quoting that has to this day been written on the subject."

Jeremy Bentham had revolutionized the prison system of England, and had introduced the system of labor in penitentiaries which has become an essential element in all modern penal systems. Woodworking was the most available field of work, but the greater part of the prisoners were of course unskilled, and Samuel Bentham was called upon to devise machines to meet the need. The two brothers established a factory and began making woodworking machinery for the prisons and dockyards.

The work for the dockyards soon took definite form. Pulley blocks formed one of the important supplies of the navy. A single full-rigged frigate used about 1500 and the Admiralty were purchasing at that time about 100,000 yearly. This formed a large business in itself and one in which the interchangeability that Bentham

1 See the biography of Bentham, by William Lucas Sargant: "Essays of a Birmingham Manufacturer," Vol. I, No. V. London, 1869. Also, "Memoirs of the late Brigadier-General Sir Samuel Bentham," by Mary S. Bentham, in "Papers and Practical Illustrations of Public Works." London, 1856. 
was continually urging was especially desirable. On Bentham's recommendation, a government factory organized on a manufacturing basis and utilizing machinery had been begun at Portsmouth and a few machines of his design already installed, when Brunel, who hnd been working independently on block machinery, was introduced to him.

Marc Isambard Brunel, Fig. 10, was a Norman Frenchman, born in 1769, who was the despair of his father because he would not study to be a priest and would persist in drawing and in making things. As a family compromise he received a naval training and served as an officer for six years. In 1793, his ship being paid off, he was in Paris. His outspoken loyalty in one of the cafés on the very day when Louis XVI was sentenced to the guillotine brought down upon him the anger of the republicans present. He escaped in the confusion, spent the night in hiding, and leaving Paris early the next morning, made his way to Rouen. Here he hid for a time with M. Carpentier, the American consul, in whose home he met a young English girl whom he afterwards married. Six months later he sailed from Havre on a forged passport, under the nose of a frigate searching for suspects, and landed in New York only to find a French republican squadron lying in port. As he was personally known to many of the officers and in danger of being recognized, arrested and condemned as a deserter, he left the city at once and went to Albany in the vague hope of finding $M$. Pharoux, a friend who was undertaking the survey of a large tract of wild land in the Black River valley, east of Lake Ontario. Brunel found him by good chance, joined the party, and soon became its real leader. They showed the capacity, which the French have always had, of working in friendly relationship with the Indians, and their work was suc- 


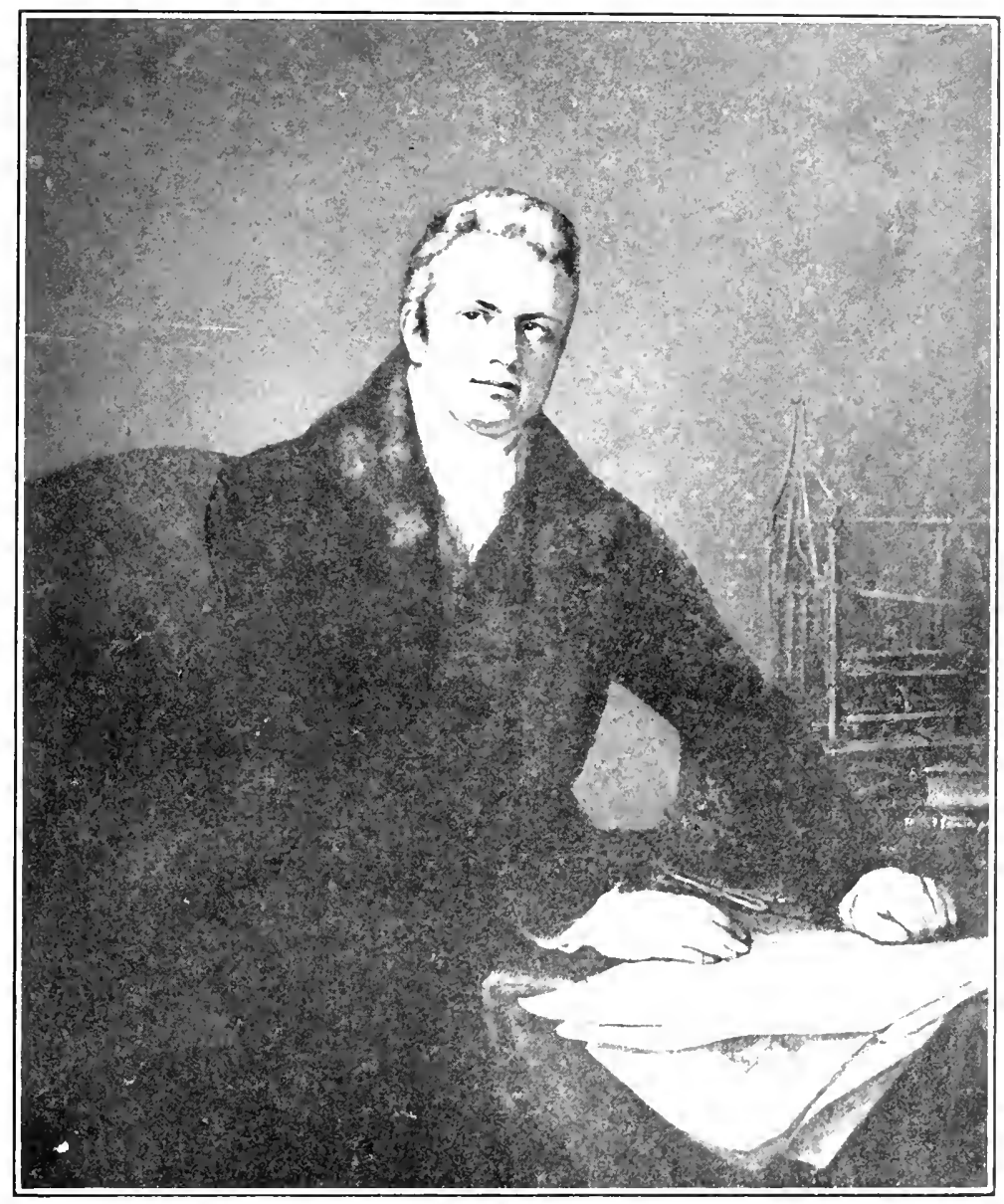

Figere 10. Sir Mare Isiabard Brovel

From a Photociraph by Waker, latd., gf the Portrat ix the Nitional Gialeri, Londoy 
cessfully accomplished. Fifty years later there were still traditions among Indians in the valley of a wonderful white man named "Bruné."

Brunel remained in America for over five years and was naturalized as a citizen in 1796. During this time he was engaged on the Hudson-Champlain canal and various river improvements. $\mathrm{He}$ was a friend of Major L'Enfant, who planned the city of Washington and he submitted one of the competitive designs for the original Capitol. He also designed and built the old Park Theater in New York, which was burned in 1821. He was appointed chief engineer of New York, built a cannon foundry and had a part in planning the fortifications of the Narrows in New York harbor.

He was gay, refined and a favorite among the emigrés who enlivened New York society in the closing years of the eighteenth century. It was at Alexander Hamilton's dinner table that the first suggestion of the block machinery came to him. He had been invited to meet a M. Delabigarre, who had just arrived from England. M. Delabigarre had been describing the method of making ship's blocks and spoke of their high and increasing cost. Brunel listened with attention and then pointed out what he considered the defects of the method and suggested that the mortises might be cut by machinery, two or three at a time. The shaping machine he afterward used was conceived while he was at Fort Montgomery in the highlands of the Hudson. Brunel left America for England early in 1799 and remained in England the rest of his life. His marriage soon after his arrival to Miss Kingdom, the girl whom he had met at Rouen, doubtless gives the reason for this change. Two months after reaching England. he took out a patent for a writing and duplicating machine and he also invented a machine for twisting cotton thread. Mean- 
time he was working on the drawings for a complete set of block machinery, and by 1801 he had made a working model of the mortising and boring machines. He offered his plans to Fox \& Taylor, who held the navy contract for blocks. Mr. Taylor wrote in reply that his father had spent many years developing their existing methods of manufacture and they were perfectly satisfied with them. He added, "I have no hope of anything better ever being discovered, and I am convinced there cannot."

Brunel, through introductions brought from America, then laid his plans before Lord Spencer, of the Admiralty, and Sir Samuel Bentham. Bentham, as we have seen, was already working on the same problem. He saw at once the superiority of Brunel's plans and, with the freedom from jealousy and self-interest which characterized his whole career, he recommended their adoption, with the result that Brunel was commissioned to build and install his machines.

About sixty years ago there was a sharp controversy over the origin of this Portsmouth machinery. Partisans of Bentham and Brunel each claimed the entire credit for all of it. The fact is that some of Bentham's machines were used for the roughing out, but all the finishing work was done on Brunel's, and there is little doubt that the definite plan of operations and all the more intricate machines were his. Bentham conceived the enterprise and had it well under way. His broadminded and generous substitution of Brunel's plans for his own was quite as creditable to him as the execution of the whole work would have been.

While Brunel was a clever and original designer, he was not a skilled mechanic. His plans called for a large number of refined and intricate machines which were wholly new and he no sooner began actual work than he felt the need of a mechanic capable of building them. 
Maudslay had just started in for himself and was working in his little shop on Oxford Street, with one helper. M. Bacquancourt, a friend of Brunel's, passed his door every day and was interested in the beautiful pieces of workmanship he used to see from time to time in the shop window. At his suggestion Brunel went to Maudslay, explained to him his designs, and secured his help. There could hardly have been a better combination than these two men. Maudslay's wonderful skill as a mechanic and his keen, practical intuition supplied the one element needed and together they executed the entire set of machines, forty-four in all. ${ }^{2}$

The machinery was divided into four classes.

First. Sawing machines, both reciprocating and circular, for roughing out the blocks.

Second. Boring, mortising, shaping and "scoring" machines for finishing the blocks.

Third. Machines for turning and boring the sheaves, for riveting the brass liner and finish-facing the sides. In the larger sizes small holes were drilled on the joint and short wire pins riveted in to prevent slipping between the liner and block.

Fourth. The iron pins on which the sheaves turned were hand forged in dies, turned and polished.

In addition to these there were several machines for forming "dead eyes," or solid blocks without sheaves, used in the fixed rigging. A detailed description of the entire set would be too long. A brief description of one or two of the machines will serve to give some idea of the others,

2 For a description of the Portsmouth Block Machinery, see Tomlinson's "Cyclopedia of Useful Arts," Vol. I, pp. 139-146. London, 1852. Also, Ure's "Dictionary of Arts, Manufactures, and Mines," Vol. I, pp. 398-402 ; Seventh Edition. London, 1875; and Rees' "Cyclopedia," article " Machinery for Manufacturing Ship's Blocks." 
Fig. 11 is taken from an old wood-cut of the mortising machine. ${ }^{3}$ A model of it is shown in the background of the portrait of Brunel in the National Gallery, reproduced opposite page 26. A pulley and flywheel are connected by a cone clutch $M$ to a shaft $D$. At the front end of this a crank and connecting-rod drive the reciprocating cutter head from a point $a$. The chuck carrying the block, movable forward and backward on guides, was operated by the feed screw $R$, a cam, and the ratchet motion shown. A system of stops and weighted levers on the side threw out the ratchet feed at the end of the cut, and the carriage was returned by hand, using the crank $r$. The crosshead had two guiding points, a double one below the driving point and a single one above it at $F$, and made 150 strokes per minute. The chuck could take either one or two blocks at a time.

Fig. 12 shows the shaping machine. ${ }^{4}$ Ten blocks were chucked between two large, circular frames, the same working points being used as in the last machine. The principle of establishing and adhering to working points seems to have been clearly recognized. A cutter $g$ was moved across the face of the blocks as they revolved, its motion being governed by the handles $l$ and $G$ and a former $i$. One side of each of the ten blocks was thus finished at a time. The blocks were then indexed $90^{\circ}$ by revolving the bevel $K$, which turned the wormshafts $d$ and rotated all the chucks simultaneously. The blocks were then faced again in their new positions and the operation continued until the four sides were finished. The strong curved bars at the top were provided to protect the workman in case one of the blocks should let go. As the momentum of the frame and blocks was con-

3 Tomlinson: "Cyclopedia,", Vol. I, p. 141.

4 Ibid., Vol. I, p. 144. 


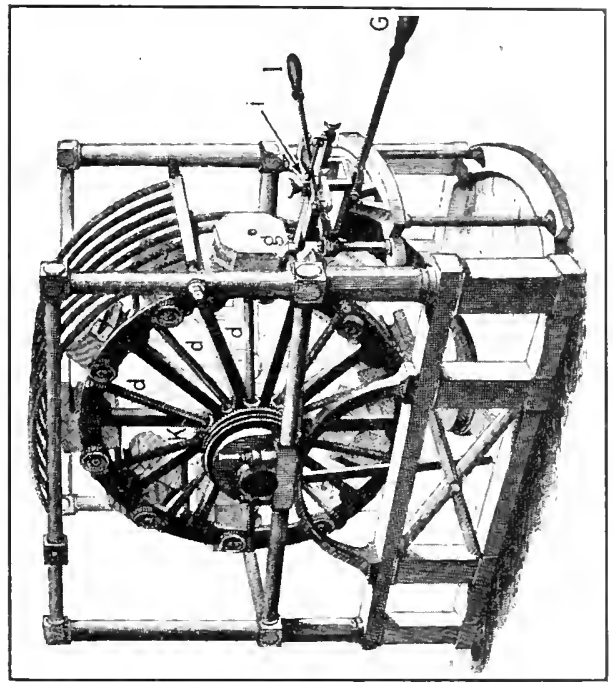

要

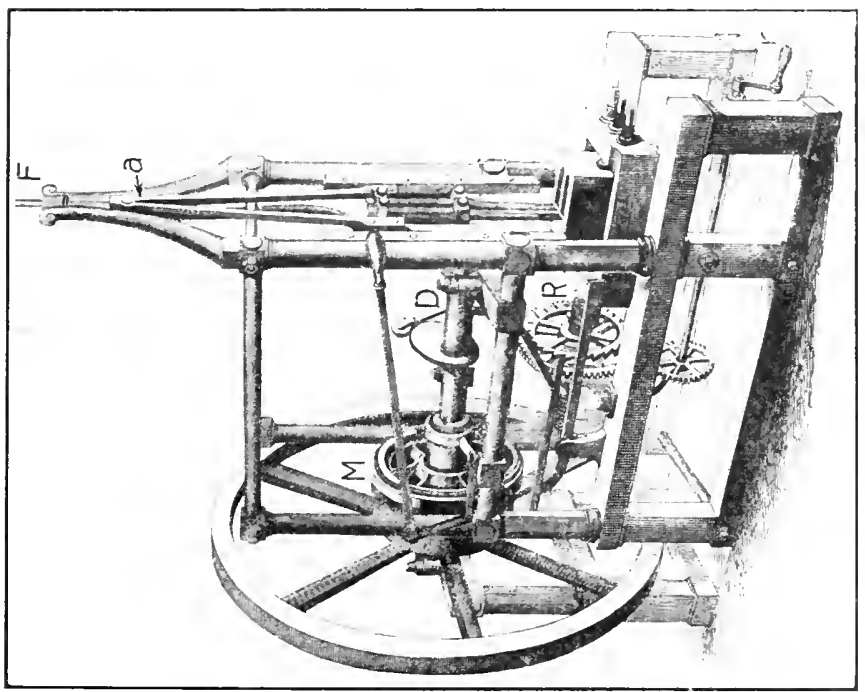

焉焉 
siderable, a spring brake was provided between the bearing and bevel-gear to bring them to rest quickly.

Another well-designed machine "scored" the outside of the blocks for the ropes or straps. Two disks with inserted steel cutters grooved the blocks which were chucked on a swinging frame. The depth and path of cut were governed by a steel former against which a roller on the cutter shaft bore. In the metal working machines, under the fourth group, cutters were used in which a short, round bar of tempered steel was held by a binding screw in a holder of the lathe-tool type. From the sketch of it shown by Holtzapffel, the whole device might almost be used as an advertisement for a modern tool-holder for high-speed steel cutters.

Enough has been said to show that these machines were thoroughly modern in their conception and constituted a complete range of tools, each performing its part in a definite series of operations. By this machinery ten unskilled men did the work of 110 skilled workmen. When the plant was in full running order in 1808 the output was over 130,000 blocks per year, with a valne of over $\$ 250,000$, an output greater than that previously supplied by the six largest dockyards. It continued for many years to supply all the blocks used by the Royal Navy, and was in fact superseded only when wooden blocks themselves largely made way for iron and steel ones.

Brunel devised other woodworking tocls, but none so successful as these. He started a mill at Battersea which burned down; his finances became involved and he was thrown into prison for debt. $\mathrm{He}$ was freed through a grant of $\$ 25,000$ which friends secured from the government. His later work was in the field of civil engineering - the most famous work being the Thames 
tunnel. He was given the Legion of Honor in 1829, was knighted in 1841 , and died in $1849 .^{5}$

His son, Sir Isambard K. Brunel, was also one of the foremost engineers of England, a bridge and ship builder, railway engineer and rival of Robert Stephenson. At the age of twenty-seven he was chief engineer of the Great Western Railway, and built the steamer "Great Western" to run from Bristol to New York as an extension of that railway system. This was the first large iron ship, the first regular transatlantic liner, and the first large steamship using the screw propeller. Its success led to the building of the "Great Eastern" from his designs. This ship was about 700 feet long and for nearly fifty years was the largest one built. She was a disastrous failure financially and after a varied career, which included the laying of the first transatlantic cable, she was finally broken up. Brunel was a strong advocate of the broad gauge and built the Great Western system with a 7 -foot gauge, which was ultimately changed to standard gauge. While a number of his undertakings were failures financially, his chief fault seems to have been that he was in advance of his generation.

5 For fuller information, see the biography of Sir Marc Isambard Brunel by Richard Beamish, F.R.S. London, 1862 . 


\section{CHAPTER IV}

\section{HENRY MAUDSLAY}

We have mentioned Henry Maudslay frequently. In fact, it is hard to go far in any historical study of machine tools without doing so. ${ }^{1}$

Maudslay was born in Woolwich in 1771 . He was the son of an old soldier working in the arsenal, and had but little schooling. At twelve he was at work in the arsenal, first as a "powder monkey" filling cartridges, later in the carpenter shop and smithy. Young as he was, he soon became the leader among the workmen. He was a born craftsman and his skill was soon the pride of the whole shop. To dexterity he added an intuitive power of mechanical analysis and a sense of proportion possessed by few men, and from the beginning he showed a genius for choosing the most direct and simple means for accomplishing his purpose. He was a great favorite among his fellows from his fine personal appearance, his open-heartedness and complete freedom from conceit.

In the chapter on Bramah we have seen how Bramah, seeking someone to help him devise tools to manufacture his locks, turned first to an old German mechanic in Moodie's shop. One of the hammer men in Moodie's shop suggested Maudslay, apologizing for his youth, but adding that "nothing bet him." When Bramah saw Maudslay, who was only eighteen, he was almost ashamed to lay his case before him. Maudslay's suggestions,

I For best accounts of Maudslay, see Smiles' "Industrial Biography," Chap. XII, and "Autobiography of James Nasmyth." 
however, were so keen and to the point that the older man had to admit that the boy's head at least was old enough. He adopted the suggestions and offered him a job in his shop at Pimlico, which Maudslay gladly accepted. As he had served no apprenticeship, the foreman had doubts of his ability to work among experienced hands. Without a moment's hesitation Maudslay pointed to a worn-out bench vice and asked whether he could take his rank among the other workmen if he could fix it as good as new before the end of the day. He was told to go ahead. He resteeled and trued the jaws, filed them up, recut and hardened them, and before the time set had it together, trimmer and in better shape than any of its neighbors. It was examined, admired and accepted as his diploma as a journeyman.

His advancement was rapid, and in about a year, while still only nineteen, he was made general foreman and maintained his leadership without the slightest difficulty. He remained with Bramah for eight years, during which time the two laid the foundation for many of the modern machine tools, more especially the slide-rest and screwcutting lathe. We have already considered Maudslay's work done in connection with Bramah and little need be added here in regard to it. During this time Bramah invented the hydraulic press, but the cup-leather packing which is so essential a part of it was suggested by Maudslay.

He left the Pimlico shop because Bramah would not give him more than 30 shillings $(\$ 7.50)$ a week, and with a single helper started a little blacksmithing and jobbing shop on his own account near Wells and Oxford streets in London.

His first customer was an artist who gave him an order for an iron easel. Business prospered and he found plenty of work. His reputation was established, how- 
ever, in connection with the Portsmouth block machinery, which was described in the last chapter. The building of this machinery occupied about eight years, from 1800 to 1808 . The design was substantially Brunel's, but Mr. Nasmyth says that "every member of it was full of Maudslay's presence and the mechanical perfection of its details, its practicability and adaptability show his handiwork at every turn."

Soon after this work was undertaken, Maudslay moved his shop to Margaret Street, near Cavendish Square. During the building of the block machinery Maudslay had met Joshua Field, who had been engaged as a draftsman in the Portsmouth dockyards under Sir Samuel Bentham and had worked with him in the development of the machinery. Field was transferred to General Bentham's office at the Admiralty in 1804, and a year later joined Maudslay. Five years later they moved to Lambeth on the south side of the Thames and bought an old riding school on Westminster Road on what was formerly a swampy marsh. Here the firm of Maudslay \& Field continued its long and famous career. Few firms have influenced mechanical development more, and for many years it was one of the leading machine shops of the world. Here Maudslay did his life work as one of the leaders in the development not only of machine tools but of the steam engine, both stationary and marine. After his death in 1831 the business was continued by Mr. Field, who outlived him many years, and by Maudslay's son and grandson, both of whom were fine mechanics and men of great influence.

It was in connection with the slide-rest and screwcutting lathe that Maudslay is best known. Too much value cannot be placed on the slide-rest and its combination with a lead screw, operated by change gears. It is 
used in some form in almost every machine tool and is one of the great inventions of history.

Like most of the great inventions, it was the work of many men. In crude applications, parts of it date back to the Middle Ages. Leonardo da Vinci caught an inkling of it. French writers in the sixteenth and seventeenth centuries describe and illustrate devices which involve the parts of it. Fig. 13, reproduced from an illustration in the old work of Besson, first published in 1569,2 shows a lead screw. The copy from which this illustration was taken is printed in Latin and is in the Astor library, New York. The upper shaft had three drums; the middle one carried the rope which was manipulated by the operator. Of the drums at the ends, the one at the left operated a lead screw and the one on the right, the piece being cut. The two outer weights held the follower up against the lead screw. The cutting was, of course, intermittent, as in all the earlier types of lathes. The idea of the lead screw occurs in other French works of the seventeenth and eighteenth centuries. In the lathe shown in Fig. 14, from a French book published in $1741,{ }^{3}$ gears instead of ropes were used to connect the rotation of the lead screw with that of the work, but if the idea of change gears was contemplated, it was not developed.

The slide-rest was also known. An illustration of a French slide-rest, published long before Maudslay's time, is reproduced in Fig. 3. In Bramah's original "slide-tool," the tail-stock and slide-rest were com-

2 "Des Instruments Mathématiques et Méchaniques, \&c., Inventées par Jacques Besson." First Latin and French Edit., 1569. Plate 9. Two later editions were published at Lyons, one in 1578 and one in 1582 . The same copper plates were used in the three editions.

${ }^{3}$ Holtzapffel: "Turning and Mechanical Manipulation," Vol. II, p. 618. London, 1847. 


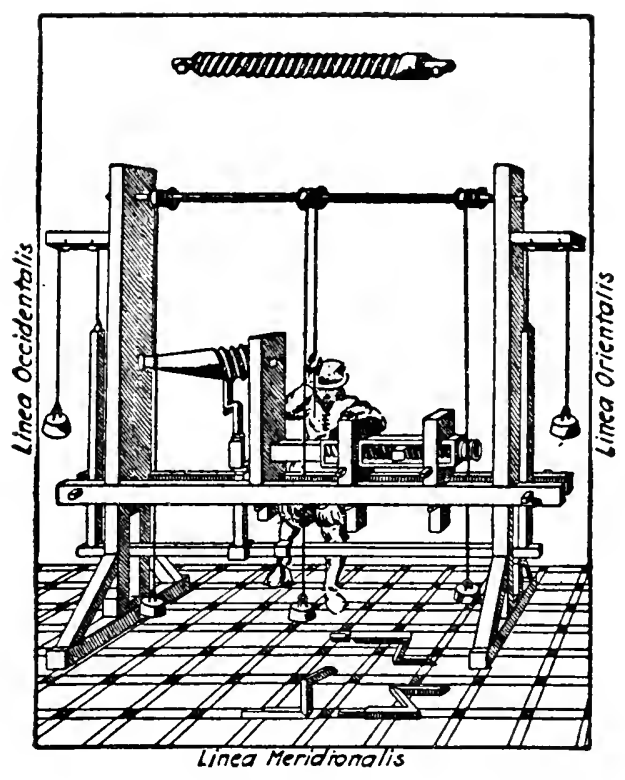

Figure 13. French Screw-Cutting

Lathe, Previous to 1569

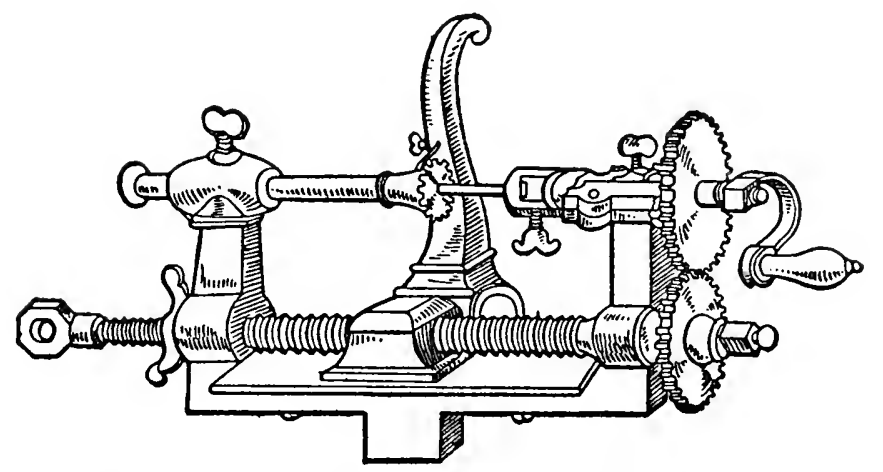

Figure 14. French Screw-Cutting Lathe, abott 1740 
bined.4 It was made about 1795 by Maudslay while still his foreman. How much of the design was Bramah's and how much Maudslay's we cannot tell. It was a light, flimsy affair and very different from the slide-rests Maudslay was making only a few years later.

In none of these was the slide-rest combined with change gears and a power-driven lead screw. It was this combination which formed Maudslay's great contribution, together with improvements in proportion and in mechanical design which raised the device from an ingenious but cumbersome mechanical movement to an instrument of precision and power. Jesse Ramsden, a famous instrument maker, is said to have made a small lathe in 1775 , which had change wheels and a sliding tool holder moved by a lead screw. The writer has been unable to find any illustration or description of it, and if such a lathe existed, it certainly did not exert a very wide influence. The combination was anticipated in Bentham's famous patent of 1793 . In this patent Bentham says: "When the motion is of a rotative kind, advancement (of the tool) may be provided by hand, yet regularity may be more effectually insured by the aid of mechanism. For this purpose one expedient is the connecting, for instance, by cogged wheels, of the advancing motion of the piece with the rotative motion of the tool.",5 This patent contained no drawings, and the suggestion was not, so far as is known, embodied in any definite construction.

Many men were working at the problem of generating an accurate screw thread. The use of dies was quite well known, but their design and workmanship was of the crudest order and their product of the same charac-

4 Buchanan: "Practical Essays on Mill Work and Other Machinery." London, 1841. Volume of Plates.

s See the British patent records. Patent No. 1951, dated April 23, 1793. 
ter; and they were inadequate for the making of any large threads. Holtzapffel's book on "Turning and Mechanical Manipulation,"' published in London, 1847, describes some of the attempts of the earlier mechanics to devise other means. ${ }^{\circ}$ At the famous Soho works in Birmingham a workman by the name of Anthony Robinson cut a screw 7 feet long and 6 inches in diameter with a square, triple thread. After the cylinder had been turned, paper was cut and fitted around it, removed, marked in ink with parallel oblique lines, then replaced on the cylinder and the lines were pricked through with a center punch. The paper was again removed and dots connected by fine lines with a file. The alternate spaces between the lines were then cut out with a chisel and hammer and smoothed by filing. A block of lead and tin, as a temporary guide nut, was then cast around the partially formed screw. Adjustable cutters were fixed upon this guide nut and it was used as a kind of tool-holding slide-rest, being rotated around the screw by hand levers, thereby cutting the finished thread. In other words, a lead screw was cut on the piece itself and the temporary nut was used as a tool holder to finish the work.

One method used for some purposes was to coil two wires around a core in close contact with each other. One of these was then removed, leaving a space corresponding to the hollow of the thread. The core and remaining wire were then dipped in melted tin and soldered together. In some cases they were actually used in this form as the desired screw thread. In others, the helical wire was used to guide a sleeve nut which controlled a tool used to cut a thread located farther up on the length of the core.

Another method resorted to was that of grooving a smooth cylinder by a sharp-edged cutter standing at the

${ }^{6}$ Holtzapffel. Vol. II, pp. 635.655. 
required pitch angle and relying on the contact of the knife-edge to produce the proper traverse along the cylinder as it was rotated, thus developing the screw. This method is not so crude as it seems and was one of those used by Maudslay himself. He also used a flat steel tape wound about a cylindrical bar, but he found the inclined knife method more satisfactory. The device which he used was a mechanism of considerable refinement. He employed cylinders of wood, tin, brass and other soft metals accurately mounted to revolve between centers. The hardened knife was crescent-shaped, nearly fitting the cylinder, and fixed at the required angle with great precision by means of a large graduated wheel and tangent screw. A chasing tool carried by a small, adjustable slide cut the thread as the stock moved forward under the incisive action of the inclined knife edge. Hundreds of screws, both right and left, were made by this device, and their agreement with each other is said to have been remarkable. This was the way in which Maudslay generated his first lead screws.

With the best of the screws so obtained Maudslay made the first screw-cutting lathe a few years prior to 1800, shown in Fig. 15,' which had two triangular bars for a bed, and was about three feet long. The headstock carried a live spindle, which was connected with a lead screw by a pair of gears, and a slide-rest ran upon the triangular bars under control of a lead screw having four square threads per inch. In this machine he at first used different lead screws for different pitches. The inner end of the lower spindle in the headstock had a two-jawed driving device, which might be disconnected and into which various lead screws might be fitted. Later he added change gear wheels.

$\tau$ No. 1601 in South Kensington Museum, London. Cat. M. E. Collection, Part II, p. 266. 
The great idea of using a single lead screw for various pitches, by means of change gears, was Maudslay's own. Fig. 16 shows how rapidly the idea was developed. 8 This machine, built about 1800 , is distinctly modern in appearance. It has a substantial, well-designed, cast-iron bed, a lead screw with 30 threads to the inch, a back rest for steadying the work, and was fitted with 28 change wheels with teeth varying in number from 15 to 50 . The intermediate wheel had a wide face and was carried on the swinging, adjustable arm in order to mesh with wheels of various diameters on the fixed centers. Sample screws having from 16 to 100 threads per inch are shown on the rack in front. Both of these lathes are now in the South Kensington Museum in London. With lathes of this design, Maudslay cut the best screws which had been made up to that time. One of these was 5 feet long, 2 inches in diameter, with 50 threads to the inch, and the nut fitted to it was 12 inches long, thus engaging 600 threads. "This screw was principally used for dividing scales for astronomical and other metrical purposes of the highest class. By its means divisions were produced with such minuteness that they could only be made visual by a microscope."

Some idea of how far Maudslay was in advance of his time is shown by the fact that the wooden pole-lathes in Fig. 2 represent fairly the state of the art at that time. This form had been in use in many countries for centuries. One of these wooden lathes, built in 1800 , the same year as Maudslay's lathe, Fig. 16, is also in the South Kensington Museum, and was in use as late as

8 No. 1602 in South Kensington Museum, London. Cat. M. E. Collection, Part II, pp. 266-267.

" "Autobiography of James Nasmyth" p. 140. London, 1883. 
1879. Similar lathes are said to be still used by chair makers in certain portions of England. ${ }^{10}$

About 1830, shortly before his death, Maudslay designed and constructed a lathe with a face-plate 9 feet in diameter operating over a pit 20 feet deep. This lathe had a massive bed and was used to turn flywheel rims. It was fitted with a boring bar and was capable of boring steam cylinders up to 10 feet in diameter. We regret that no picture of this lathe is available. It would be interesting as it would show in a striking way the development of the slide-rest and lathe in the hands of this great mechanic.

Maudslay's work on the screw thread was not confined to the lathe. He improved the system of taps and dies whereby they were made to cut the threads instead of squeezing them up, and he introduced the use of three or more cutting edges. ${ }^{11}$ He made the first move toward the systematizing of thread sizes and made a series of taps from 6 inches in diameter, for tapping steam pistons, down to the smallest sizes used in watch work. The diameters of these taps varied by eighths and sixteenths of an inch, and their threads were determined by the respective strengths of each screw. He established for his own use definite standard pitches. Many copies of these threads found their way to other shops and influenced the construction of similar tools elsewhere. In fact, Holtzapffel says: "I believe it may be fairly advanced, that during the period from 1800 to $1810, \mathrm{Mr}$. Maudslay effected nearly the entire change from the old, imperfect, accidental practice of screw making to the modern, exact, systematic mode now generally followed by engineers; and he pursued the subject of the screw

10 No. 1596 in South Kensington Museum, London. Cat. M. E. Collection, Part II, p. 264.

11 Holtzapffel, Vol. II, p. 646. 


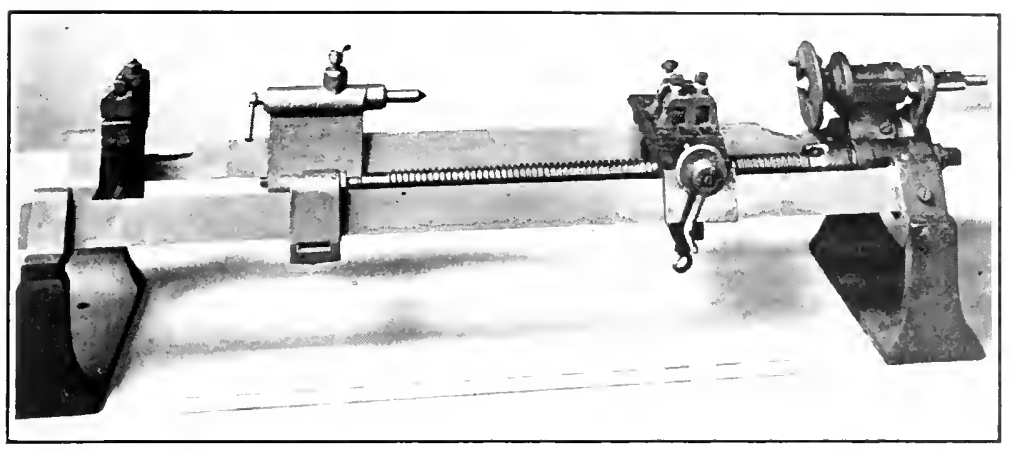

Figure 15. Maudslay's Sicrew-C'ctting Lathe

Abort 1797

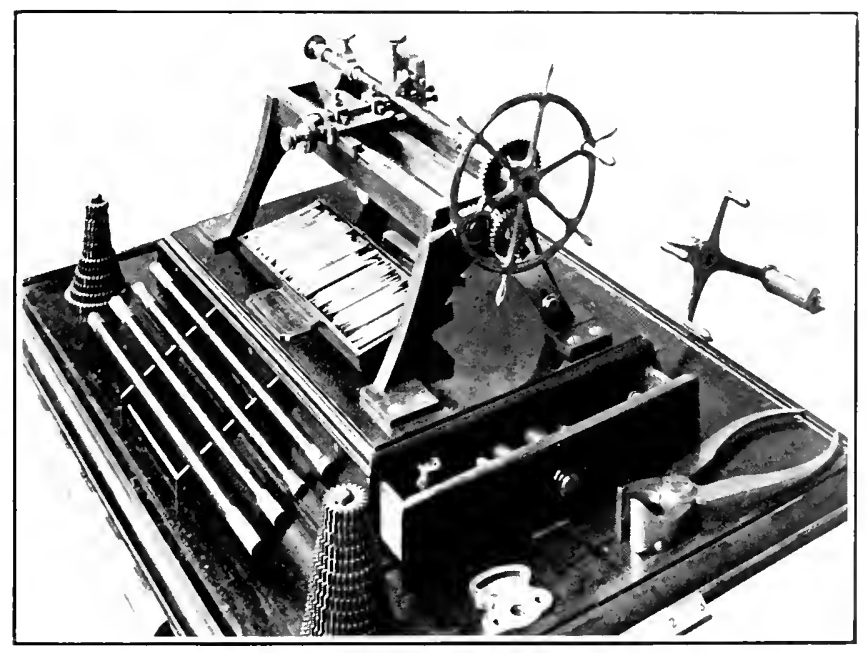

Figure 16. Maudahy's Screw-C'ttTing Lathe

ABOLt 1500 

with more or less ardour, and at an enormous expense, until his death." ${ }^{2}$

While we would not detract from the ingenuity of others who conceived the idea of the slide-rest and lead screw, enough has been given to show that no other mechanic of his day appreciated their possibilities as he did, and none embodied them in forms as useful. The fact that for many years the slide-rest was popularly known as "Maudslay's go-cart" indicates that his contemporaries recognized him as its originator.

The business at Lambeth grew steadily until it employed several hundred men, and embraced the making of saw- and flour-mills, mint machinery and steam engines of all kinds. With his keen mechanical intuition he saw that the cumbersome wooden walking beam characteristic of the Newcomen and Watt engines was unnecessary. He therefore dispensed with it and drove direct from the engine crosshead to the crank, thus making the first direct-acting engine, which held the market for a long time. He built the first marine engines in England, and his leadership in that field was unchallenged for many years. Another of his inventions was the punching machine for punching boiler plates and iron work. His influence was felt in many directions in the field of machine design. He was the first to point out the weakness of the clean, sharp corners in castings which were so prized at that time, and advocated the use of fillets, showing that they greatly increased the strength.

To the end of his life he retained his personal dexterity at both the anvil and the bench. One of his greatest delights was to go into the shop and "have a go" at a piece of work which his workmen found impossible to do. One of his old workmen, years afterward, 12 Ibid., Vol. II, p. 647. 
speaking in kindling pride of him, said: "It was a pleasure to see him handle a tool of any kind, but he was quite splendid with an 18-inch file." Nasmyth confirms this, saying: "To be permitted to stand by and observe the systematic way in which Mr. Maudslay would first mark or line out his work, and the masterly manner in which he would deal with his materials, and cause them to assume the desired forms, was a treat beyond all expression. Every stroke of the hammer, chisel, or file, told as an effective step towards the intended result. It was a never-to-be-forgotten lesson in workmanship, in the most exalted sense of the term. . . . No one that I ever met with could go beyond Henry Maudslay himself in his dexterous use of the file. By a few masterly strokes he could plane surfaces so true that when their accuracy was tested by a standard plane surface of absolute truth they were never found defective; neither convex nor concave nor 'cross-winding,'-that is, twisted." "13

Whitworth is usually credited with having been the originator of the method of making plane surfaces three at a time, using them to correct each other. Nasmyth, however, says that Maudslay used this method and that surface plates so made were in daily use in his shop. His testimony is so clear that it is given in full: "The importance of having Standard Planes caused him [i.e., Maudslay] to have many of them placed on the benches beside his workmen, by means of which they might at once conveniently test their work. Three of each were made at a time so that by the mutual rubbing of each on each the projecting surfaces were effaced. When the surfaces approached very near to the true plane, the still projecting minute points were carefully reduced by hard steel scrapers, until at last the standard plane surface was secured. When placed over each other they ${ }_{13}$ "Autobiography of James Nasmyth," pp. 147-148. London, 1883. 
would float upon the thin stratum of air between them until dislodged by time and pressure. When they adhered closely to each other, they could only be separated by sliding each off each. This art of producing absolutely plane surfaces is, I believe, a very old mechanical 'dodge.' But, as employed by Maudslay's men, it greatly contributed to the improvement of the work turned out. It was used for the surfaces of slide valves, or wherever absolute true plane surfaces were essential to the attainment of the best results, not only in the machinery turned out, but in educating the taste of his men towards first-class workmanship." ${ }^{14}$ Whitworth's later success with the generation of plane surfaces seems clearly to be a refinement and outgrowth of Maudslay's work.

Maudslay's standard of accuracy carried him beyond the use of ordinary calipers, and he had a bench micrometer of great accuracy which he kept in his own workshop and always referred to as "The Lord Chancellor." It was about 16 inches long and had two plane jaws and a horizontal screw. The scale was graduated to inches and tenths of an inch; and the index disk on the screw to one hundred equal parts. Speaking from the standpoint of fifty years ago, Nasmyth says: "Not only absolute measure could be obtained by this means, but also the amount of minute differences could be ascertained with a degree of exactness that went quite beyond all the requirements of engineering mechanism; such, for instance, as the thousandth part of an inch." ${ }^{15}$

Maudslay's record, as left behind him in steel and iron, would give him a secure place in engineering history, but his influence as a trainer of men is quite as great. He loved good work for its own sake and impressed that

14 Ibid., pp. 148-149.

15 Ibid., p. 150. 
standard on all in his employ. Clement, Roberts, Whitworth, Nasmyth, Seaward, Muir and Lewis worked for him, and all showed throughout their lives, in a marked way, his influence upon them. Other workmen, whose names are not so prominent, spread into the various shops of England the methods and standards of Maudslay \& Field (later Maudslay, Sons \& Field) and made English tool builders the leaders of the world for fifty years.

J. G. Moon, who afterwards became manager of James Watt \& Company of Soho, the successor of Boulton \& Watt, was apprenticed to Maudslay, Sons \& Field and gives the following picture of the shop at the zenith of its prosperity.

There were not more than perhaps a dozen lathes in use there, with cast-iron box beds such as we now know; but nearly all the lathes had been constructed by the firm itself and were made without a bed, the poppet or back center and the slide-rest being supported on a wrought-iron triangular bar, varying in size from, say, 3-in. to 6-in. side. This bar was supported on castiron standards, and reached from the fixed lathe head to the length required of the "bed." If the lathes were self-acting, there were two such triangular bars with the guide serew running between them. The advantage of these lathes was great, for if a large chuck job was on hand, the bars could be withdrawn from the fixed head, supported on standards, and anything that would miss the roof or swing in a pit beneath could be tackled.

There was one screwing machine or lathe which all apprentices in the vice loft (as the fitting shop in which the writer was apprenticed was called) had to work during their curriculumthis was a small double-bar lathe with a guide screw between. The fixed head was on the right of the operator, and the lathe was worked by hand by means of a wheel very much like a miniature ship's steering wheel. This wheel was about 2-ft. diameter, with handles round the rim, and we apprentices were 
put at this machine to develop the muscles of the right arm. The advantages of having the fixed head on the right (instead of on the left, as in an ordinary lathe) was that in cutting a righthand thread the tool receded away from the start and ran off the end, and thus prevented a "root in," which might happen if, whilst pulling at the wheel, you became absorbed in the discussion of the abilities of a music-hall "star" or other equally interesting topies with a fellow-apprentice.

The writer remembers using a pair of calipers at that time, whose "points" were about $1 / 2$ in. wide for measuring over the tops of a thread. These were stamped "J. Whitworth, 1830," and formerly belonged to the great screw-thread reformer. Nearly all the bar lathes were driven by gut bands, and one can remember gut bands of 1 -in. diameter being used.

Most of the planing machines were made and supplied by Joseph Whitworth \& Co., and the tool boxes were of the "Jim Crow" type, which used to make a half-turn round by means of a cord when the belt was shifted at the end of each stroke, thus cutting each way. The forerunner of this used to interest the writer-a machine in the vice loft that was variously called a shaping machine and a planing machine. It was driven by means of a disc about 3 -ft. diameter, with a slot down the disc for varying the stroke. A connecting rod from the disc to the tool box completed this portion of the machine. The tool box was supported and kept true by two cylindrical bars or guides on each side, so that the whole arrangement was like the crosshead of an engine worked by disc and connecting rod. On the top of the tool box was fixed a toothed sector of a wheel, and at the end of each stroke this sector engaged with a rack, and in this way the tool box took a half-turn and was ready for cutting on the return stroke. The writer understands that it was from this machine that Whitworth developed his "Jim Crow" tool box.

There was also a huge shaping machine, whose stroke was anything up to about $6 \mathrm{ft}$., which was simply a tool box fixed on the end of a large triangular bar of about 12 -in. side with the " $V$ " downwards. To the back of the bar was attached a rack, 
and this, gearing with a pinion, gave the motion. It was a great fascination to watch this ponderous bar with its tool box slowly coming forward out of its casing and taking immense cuts.

Another machine tool that also used to interest the writer was a machine for turning the crank pins of very large solid cranks, the crank pins being about 18 -in. to 20 -in. diameter, and the crank shafts about 24 -in. to 30 -in. diameter. These immense crank shafts used to be set in the center of the machine, and the tool would travel round the crank pin until the work was completed, the feed being worked by means of a ratchet actuated by leaden weights falling to and fro as the machines slowly revolved. ${ }^{16}$

Maudslay was a large man, over 6 feet 2 inches in height, with a large, round head, a wide forehead, a good-humored face, and keen, straightforward eyes. His ringing laugh and cordial manner made friends everywhere and his kindliness and unvarying integrity held them. It will repay anyone who cares to do so to look up the account of him as given in the "Autobiography of James Nasmyth," who went to Maudslay as a young man and worked beside him as his private assistant. In reading this affectionate account one can easily see why Maudslay influenced those about him so deeply and why he raised the standard of his craft. Like Nasmyth and many other great mechanics, Maudslay became interested in astronomy, and at the time of his death he was planning to build a 24 -inch reflecting telescope for his own use. He patented but few inventions, and relied rather upon his reputation and workmanship to protect him. He was full of quaint maxims and remarks, as true today as then, the outcome of keen observation and wide experience. He used to say: "First get a clear notion of what you desire to accomplish and then in all probability you will succeed in doing

16 Junior Institution of Engineers, pp. 167-168. London, 1914. 
it." "Keep a sharp lookout upon your material." "Get rid of every pound of material you can do without; put to yourself the question, "What business has this to be there?" "Avoid complexities. Make everything as simple as possible."

His shop was the pride of the country, and Nasmyth tells of the intimate visits of Faraday, Bentham, Brunel, Chantrey the sculptor, Barton of the Royal Mint, and Bryan Donkin the engineer, who used to call and chat with him while he worked at his bench.

No better tribute to Maudslay and his influence can be given than that of Nasmyth, who said that his "useful life was enthusiastically devoted to the great object of producing perfect workmanship and machinery; to him we are certainly indebted for the slide-rest and indirectly so for the vast benefits which have resulted from the introduction of so powerful an agent in perfecting our machinery and mechanism generally. The indefatigable care which he took in inculcating and diffusing among his workmen and mechanical men generally, sound ideas of practical knowledge and refined views of constructions, has and ever will continue to identify his name with all that is noble in the ambition of a lover of mechanical perfection. The vast results which have sprung from his admirable mind, are his best monument and eulogium." "17

17 T. Baker: "Elements of Mechanism," p. 232. Second Edition with remarks by James Nasmyth. London, 1858-1859. 


\section{CHAPTER V \\ INVENTORS OF THE PLANER}

In almost no case is the crediting of invention more difficult than in that of the planer. Not only was this tool the product of many men but no single man stands out clearly as Maudslay, for instance, does in the development of the lathe. The invention of the metal planer has been claimed in England on behalf of Spring of Aberdeen, James Fox, George Rennie, Matthew Murray, Joseph Clement and Richard Roberts. The planer was in use in the United States so early that it may also have been invented independently in this country, though, without doubt, later than in England.

With the planer as with the lathe, the French were the pioneers. Plumier, a French writer on mechanical subjects, published in 1754 a description of a machine which had been used for some years, consisting of two parallel bars of wood or iron connected at their extremities. The article to be planed was fixed between them, and a frame guided between the same bars was moved lengthwise by a long screw and carried a tool which took a planing cut from the work. The machine was intended for ornamenting the handles of knives and was said by Plumier to have been an English invention. A planing machine invented in 1751 by Nicholas Forq, a French clock maker, for the purpose of planing the pump barrels used in the Marly water works to supply the fountains at Versailles, is shown in Fig. 17. These pump barrels were made up of wrought iron staves bound together by hoops. There 


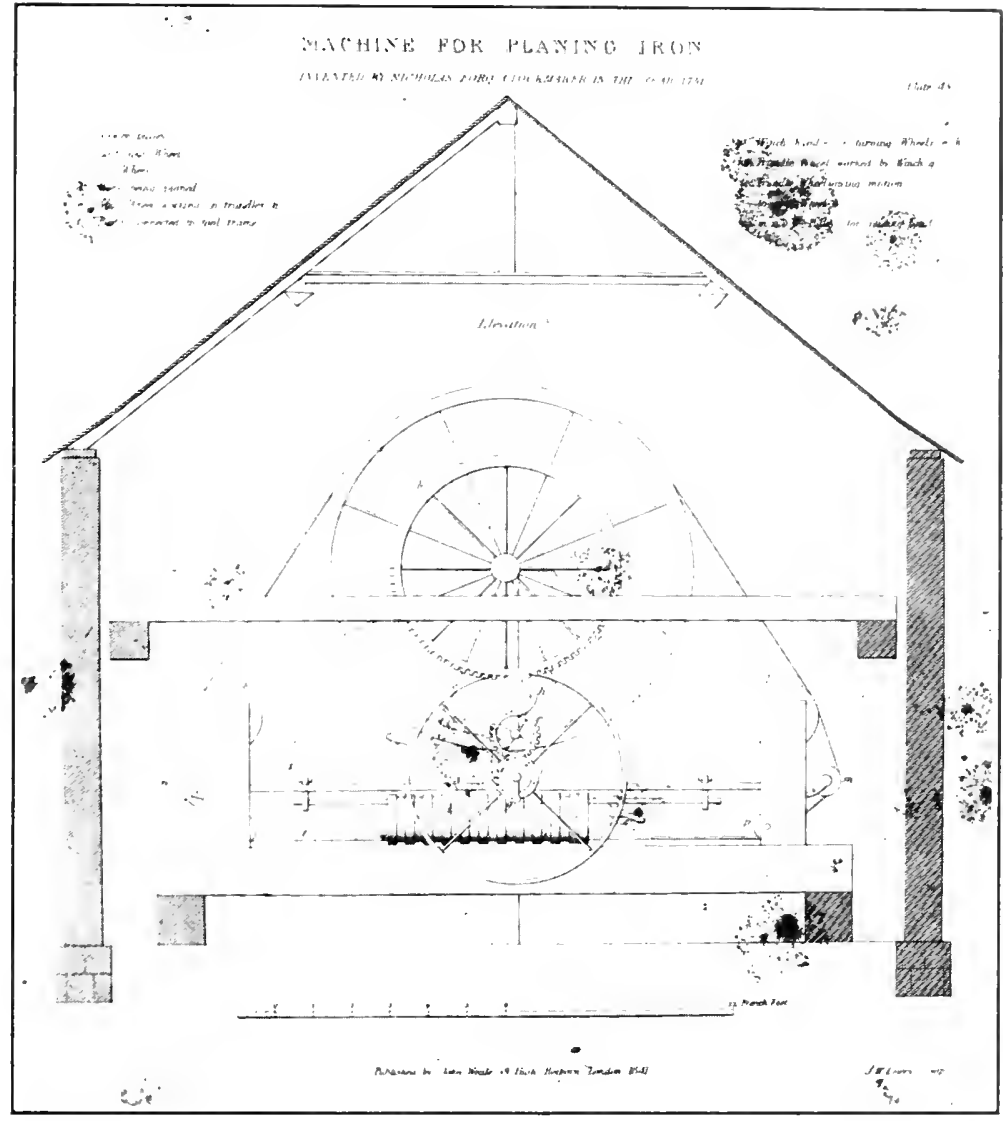

NOTE.-The spots on the photograph ufre the yellow stains of nge on the original plute

Figure 17. Frexch Plaxixg Machine by Nicholas Forq, 17,j1 

were quite a number of these barrels from 10 inches to 4 feet in diameter and from 7 feet to 10 feet long. The illustration, taken from Buchanan's "Mill Work," published in $1841,{ }^{1}$ is not complete, as it lacks the carriage carrying the planing tool which was not shown on the original drawing. The general construction of the machine however is quite clear. The built-up barrel is shown in place. The cutter was carried backward and forward between two parallel iron bars set horizontally through the cylinder. Either the tool or the pump barrel must have been given a rotative feed. Its action was therefore equivalent to planing on centers, and it is said to have done this fairly large work in a satisfactory manner.

Bentham described a planer in his well-known patent of 1793 and Bramah in his patent of 1802. Matthew Murray is said to have built one in 1814 to machine the faces of D-slide valves, which were originally invented by Murdock in 1786 but improved by Murray in 1802 . Richard Roberts built a planer in 1817 which is, without doubt, the earliest planer now in existence. It is in the South Kensington Museum in London and a picture of it is given in Fig. 20. ${ }^{2}$ It will be seen that the modern planer design was already beginning to take shape. The chisel and file marks on the bed and ways indicate that it was itself made without the use of a planer. It had verícal and horizontal feeds, an angular adjustment and separate tool-feed for the head, and a hinged clamp for the tool to allow it to lift on the return stroke. The table, which was hand-operated through a chain drive, was 52 inches long by 11 inches wide.

George Rennie built a planer in 1820 with a movable

1 Buchanan: "Practical Fssays on Mill Work and Other Machinery.' London, 1841. Volume of Plates.

2 No. 1619. Cat. M. E. Collection, Part II, p. 272. 
bed operated by a screw and furnished with a revolving cutting tool. ${ }^{3}$ James Fox built one in 1821, capable of planing work 10 feet, 6 inches long, 22 inches wide, and 12 inches deep, to plane the bars of lace machines. Joseph Clement made his first planer in 1820 to plane the triangular bars of lathes and the sides of weaving looms. Some years later he built his "great planer," a remarkable machine from both a mechanical and a financial standpoint. A very full description of it was given by Mr. Varley in the "Transactions of the Society of Arts" in London in 1832, ${ }^{4}$ illustrated by a set of copper plates made from Clement's own drawings. Clement's reputation of being the most expert draftsman of his day is well borne out by these drawings. In this planer two cutting tools were used, one for the forward and one for the return stroke. The bed ran on rollers, mounted on a concrete foundation, which were said to have been so true that "if you put a piece of paper under one of the rollers it would stop all the rest." It was fitted with centers and was used for planing circular, spiral and conical work as well as flat work. It took in work 6 feet square and was hand-driven. The cutting speed must have been low, for "the power of one man was sufficient to keep it in motion for ordinary work, though two were employed to make long and full cuts both ways." For more than ten years it was the only one of its size and it ran for many years night and day on jobbing work, its earnings forming Clement's principal income. Smiles says that his charge for planing was 18 shillings, or $\$ 4.32$, per square foot, which amounted to about $£ 10$ per day of twelve hours, or, with two shifts, to about $\$ 100$ a day. ${ }^{5}$ On this basis he must

3 Buchanan, p. xlii.

4 Vol. XLIX, p. 157.

5 Smiles: “Industrial Biography," p. 306. Boston, 1864. 
have machined an average of about 11 square feet in twelve hours.

By 1840 the design of the planer had become fairly well settled and its use general. In America, planers were built by Gay, Silver \& Company of North Chelmsford, Mass., as early as 1831. Pedrick \& Ayer of Philadelphia are also said to have built a planer at about the same time. The early American tool builders will be taken up in a later chapter.

Little is known of the personalities and histories of some of these men, such as Spring of Aberdeen. Spring's name is mentioned by Smiles in his "Industrial Biography"' as one of the inventors of the planer, but no further reference is made to him.

James Fox was the founder of a well-known firm of machine-tool builders in Derby. He was originally a butler, but his mechanical skill turned him toward the design and building of lace machinery. The gentleman in whose employ he had served furnished him with the means of beginning business on his own account, and he soon obtained work from the great firms of Arkwright and Strutt, the founders of modern cotton manufacture. His planer, built about 1814, was used in the manufacture of this machinery. It is described by Samuel Hall, a former workman under Fox, as follows: "It was essentially the same in principle as the planing machine now in goneral use, although differing in detail. It had a self-acting ratchet motion for moving the slides of a compound slide-rest, and a self-acting reversing tackle, consisting of three bevel wheels, one a stud, one loose on the driving shaft, and another on a socket, with a pinion on the opposite end of the driving shaft running on the socket. The other end was the place for the driving pulley. A clutch-box was placed between the

${ }^{6}$ p. 223. 
two opposite wheels, which was made to slide on a feather, so that by means of another shaft containing levers and a tumbling ball, the box on reversing was carried from one bevel-wheel to the opposite one." planer was in regular use as late as 1859 . The driving and reversing mechanism described above is almost exactly that used on Clement's great planer, built a dozen years later. Fox is said to have also invented a screwcutting machine, an automatic gear cutter and a selfacting lathe, but the evidence in regard to their dates is uncertain.

George Rennie was the brother of Sir John Rennie. They succeeded to the business founded by their father, the elder John Rennie, one of Watt's best-known workmen and next to Murdock the most important of his assistants, who built the Albion Flour Mills in Black Friars, where one of the first rotative engines was installed about 1788 . The mill was a great success until it burned down a few years later. John Rennie's connection with it established his reputation and he shortly after started out for himself as a millwright and founded the business which his two sons carried on for many years and which had a great influence throughout all England. Sir William Fairbairn was one of those who worked for George Rennie and furnishes another example of the cumulative influence of a succession of strong mechanics.

Matthew Murray was born at Stockton about 1765 . He was apprenticed to a blacksmith and soon became an expert mechanic. He married before his term of apprenticeship expired and as it was difficult to find sufficient work near Stockton, he left his wife behind him as soon as he was free and set out for Leeds with his bundle

7 Ibid., p. 315. 
on his back. He obtained employment with a John Marshall who had begun the manufacture of flax machinery near Adel. Murray suggested improvements which brought him a present of $£ 20$ and rapid promotion until he soon became the first mechanic in the shop. He sent for his wife and settled down in Leeds, remaining with Mr. Marshall for about twelve years. He formed a partnership with James Fenton and David Wood and started an engineering and machine-building factory at Leeds in 1795 . Here he began the manufacture of steam engines and soon established a high reputation, pushing Boulton \& Watt hard. Murdock was sent down to Leeds, called on Murray, was received cordially, and was shown freely over the entire work. On visiting the Soho works a short time afterward Murray was received cordially by Murdock, and was invited to dinner but was told that there was a rule against admitting anyone in the trade to the works. Under the circumstances Murray was indignant and declining the invitation to dinner left without further delay. A little later Boulton \& Watt attempted to "plug him up" by buying the property adjoining his factory, and this tract of land remained vacant for over 50 years. He improved the D-slide valve and did much work toward simplifying the design of the steam engine. The flat surfaces required in this type of valve led to the building of his planer. Mr. March, a well-known tool manufacturer of the next generation, went to work for Murray in 1814. Mr. March said the planer was in use at that time. "I recollect it very distinctly," he continues, "and even the sort of framing on which it stood. The machine was not patented, and like many inventions in those days it was kept as much a secret as possible, being locked up in a small room by itself, to which the ordinary workmen could not obtain access. The year in which $I$ remember it being in use was, so far as I am 
aware, long before any planing machine of a similar kind had been invented." "8

Like many of the owners of that time Murray lived directly opposite his works and he installed in his house a steam heating apparatus which excited much wonder and which must have been one of the first in use. $\mathrm{He}$ built the first locomotive which was put to successful commercial use. Trevithick had invented a steam roadengine with a single steam cylinder and a large flywheel, which had attracted considerable attention, but was wholly impracticable. It was important, however, as it had one of the first high-pressure engines, working above atmospheric pressure. In 1811 Blenkinsop of Leeds, taking his idea from Trevithick, had a number of locomotives built to operate a railway from the Middletown collieries to Leeds, a distance of $3 \frac{1}{2}$ miles. Blenkinsop was not a mechanic and the work was designed and executed by Matthew Murray. Murray used two steam cylinders instead of one, driving onto the same shaft with cranks set at right angles, and therefore introduced one of the most important features of modern locomotive design. These engines were in daily use for many years and were inspected by George Stephenson when he began his development of the locomotive. Murray's design formed the basis from which he started. The engines, however, were operated by a cog-wheel driving onto a continuous rack laid along the road bed. It was not until a number of years later that Hedley and Stephenson established the fact that the wheel friction of smooth drivers would furmish adequate tractive power. The old Blenkinsop engines, as they were called, hauled about thirty coal wagons at a speed of $3 \frac{1}{4}$ miles an hour.

Murray's most important inventions were connected with the flax industry and for these he obtained a gold 8 Ibid., p. 316. 
medal from the Society of Arts. At the time they were developed, the flax trade was dying. Their effect was to establish the British linen trade on a permanent and secure foundation. All the machine tools used in his establishment were designed and built by himself and among these was the planer which was unquestionably one of the earliest built. He made similar articles for other firms and started a branch of engineering for which Leeds became famous. He was a frank, open-hearted man, and one who contributed greatly to the industrial supremacy of England.

Joseph Clement was born in Westmoreland in $1779 .{ }^{\circ}$ His father was a weaver, a man of little education but of mental ability, a great lover of nature and something of a mechanic. Joseph Clement himself had only the merest elements of reading and writing. He started in life as a thatcher and slater, but picked up the rudiments of mechanics at the village blacksmith shop. Being grateful to the blacksmith, he repaid him by making for him a lathe which was a pretty creditable machine. On this he himself made flutes and fifes for sale and also a microscope for his father to use in his nature studies. As early as 1804 he began to work on screw cutting and made a set of die-stocks, although he had never seen any. He worked in several small country shops, then in Carlisle and in Glasgow, where he took lessons in drawing from a Peter Nicholson and became one of the most skillful draftsmen in England. Later he went to Aberdeen and was earning three guineas $(\$ 15)$ a week designing and fitting up power looms. By the end of 1813 he had saved $£ 100$. With this he went to London, meaning sooner or later to set up for himself. He first worked for an Alexander Galloway, a ward politician and trades-

9 The best information on Clement comes from Smiles' "Industrial Biography," Chap. XIII. 
man who owned a small shop. Galloway was a slovenly manager and left things to run themselves. When Clement started in he found the tools so poor that he could not do good work with them, and immediately set to work truing them up, to the surprise of his shopmates who had settled down to the slipshod standards of the shop. Seeing that Clement was capable of the highest grade work, one of his shopmates told him to go to Bramah's where such workmanship would be appreciated.

He saw Bramah and engaged to work for him for a month on trial. The result was so satisfactory that he signed an agreement for five years, dated April 1, 1814, under which he became chief draftsman and superintendent of the Pimlico works. Clement threw himself eagerly into the new work and took great satisfaction in the high quality of work which was the standard in Bramah's establishment. Bramah was greatly pleased with him and told him, "If I had secured your services five years since I would now have been a richer man by many thousands of pounds." Bramah died, however, within a year and his two sons returning from college took charge of the business. They soon became jealous of Clement's influence and by mutual consent the agreement signed with their father was terminated. Clement immediately went to Maudslay \& Field's as chief draftsman and assisted in the development of the early marine engines which they were building at that time. In 1817 he started in for himself in a small shop in Newington, with a capital of $£ 500$ and his work there until his death in 1844 is of great importance.

As already pointed out, he had been working for many years on the problem of screw cutting. Maudslay had carried this to a more refined point than any other mechanic. Profiting by Maudslay's experience, Clement began the regular manufacture of taps and dies in 1828, 


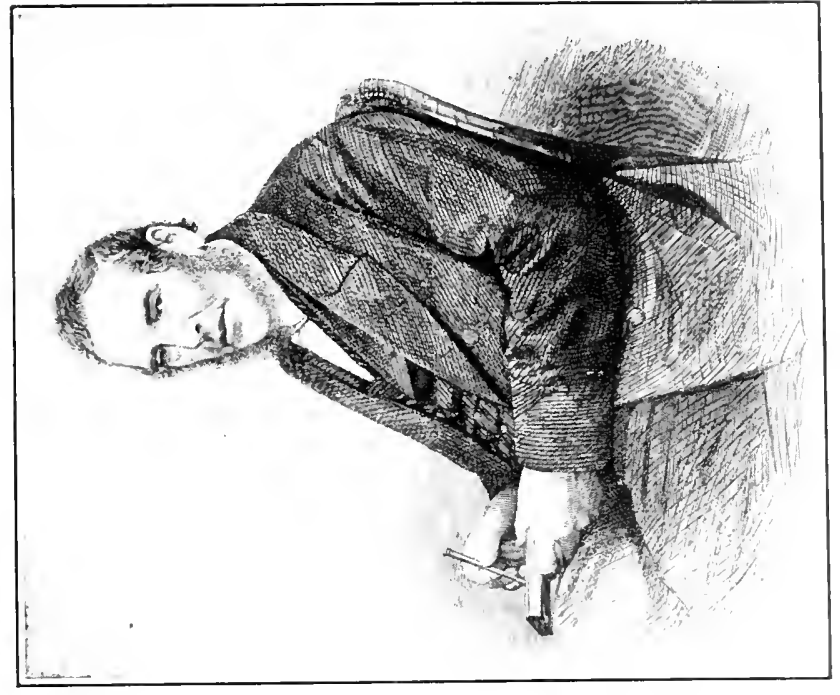

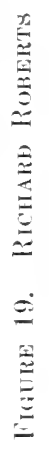

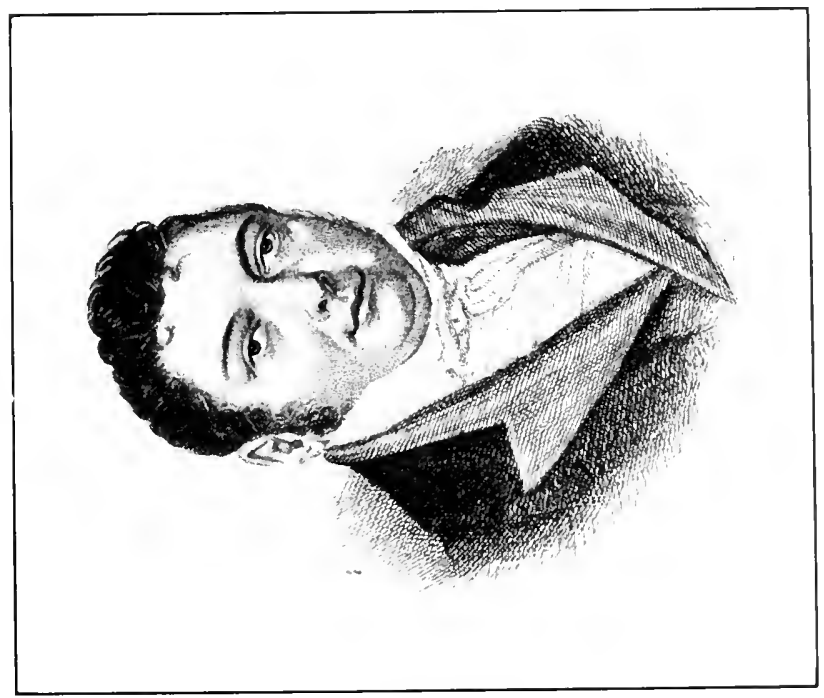

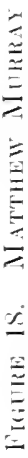



using the thread standards developed by Maudslay as his basis. He introduced the tap with a small squared shank which would fall through the threaded hole and save the time of backing out. He is said to have been one of the first in England to employ revolving cutters, using them to flute his taps. While he may have used such cutters, he was certainly not the first to do so, as they were in use in France at least thirty years earlier. $\mathrm{He}$ did important work in developing the screw-cutting lathe, again improving upon Maudslay's work and increasing the accuracy of the device. He was given a number of gold medals for various improvements in it, as well as for his work on the planer. We have already referred to his "great planer" and will only say here that of those who contributed to the early development of this machine none have had a greater influence. $\mathrm{He}$ executed the work on Charles Babbage's famous calculating machine, which attracted so much attention eighty years ago and was probably the most refined and intricate piece of mechanism constructed up to that time.

Clement was a rough and heavy-browed man, without polish, who retained until the last his strong Westmoreland dialect. At no time did he employ over thirty workmen in his factory, but they were all of the very highest class. Among them was Sir Joseph Whitworth, who continued his work on screw threads and brought about the ganeral use of what is now known as the Whitworth thread.

Richard Roberts, the last of those mentioned as inventors of the metal planer, was born in Wales in 1789 . Like most of the early mechanics he had little or no education, and as soon as he was strong enough he began work as a laborer in a quarry near his home. His mechanical aptitude led him into odd jobs and he soon became known for his dexterity. He finally determined 
to become a mechanic and worked in several shops in the neighborhood. He was employed for a time as pattern maker at John Wilkinson's works at Bradley, and is one of the few links between IVilkinson, who made the first modern metal-cutting tool-his boring machineand the later generation of tool builders.

He drifted about, a jack-of-all-trades-turner, millwright, pattern maker and wheelwright-to Birmingham, Liverpool, Manchester and finally up to London, where, after being with Holtzapffel for a short time, he found work with Maudslay in 1814 and remained with him several years. His experience here was valuable as he came in contact with the best mechanical practice. The memoir of Roberts in the "Transactions of the Institution of Civil Engineers" $"$ states that he worked on the Portsmouth block machinery, but this could hardly have been true, as that machinery was in operation by 1808. He ceased roving and did so well that he determined to return to the North and begin business for himself.

He started at Manchester in 1817 and there he spent the best years of his life. Few inventors have been more prolific or more versatile. Within a year or two he had made one of the first planers, already described; had invented the back-geared headstock, having the cone pulley running loose upon the main spindle, ${ }^{11}$ shown in Fig. 21, and made other improvements in the screw-cutting lathe; invented the first successful gas meter and built gear-cutting, broaching and slotting machines and an improved beam-scale. Holtzapffel says: "Probably no individual has originated so many useful varieties of drilling machines as Mr. Richard Roberts."' Throughout his book he frequently illustrates and describes tools

10 Vol. XXIV, p. 536. 1864.

11 Ibid., p. 537. 


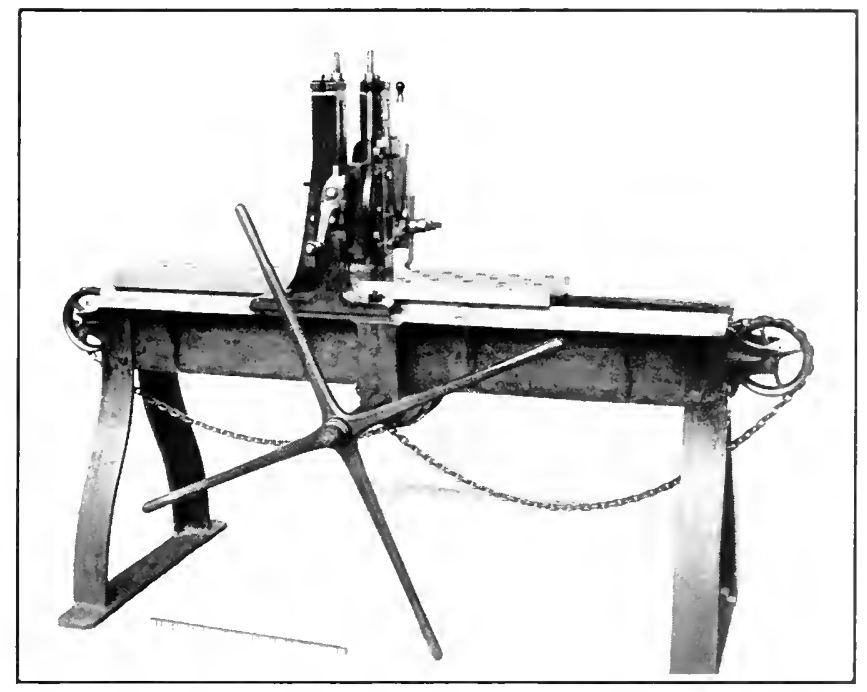

Figure 20. Roberts' Planer, Built ix 1817

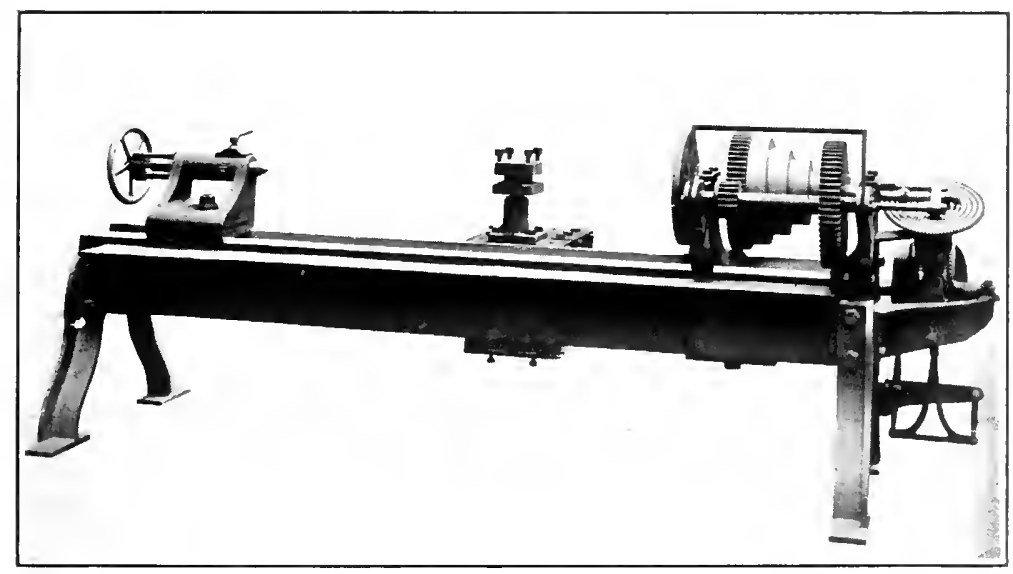

Figrre 21. Roberts' Back-Geared Lathe 
and machinery designed by Roberts, crediting him with the invention of the slotter and key-seater, which he thinks was an outgrowth of Brunel's mortising machine, Fig. 11. Roberts' punching and shearing machinery was the standard for that time. ${ }^{12}$

By 1825 his reputation had so increased that his firm, Sharp, Roberts \& Company, was asked by a committee of the cotton manufacturers of Manchester to undertake the development of an automatic spinning mule. The spinners were the highest paid labor in Lancashire textile industry, but they were difficult to work with and prone to strike on a moment's notice, closing the mills and throwing other workmen out of employment. The operators asked Roberts repeatedly to help them but he gave them no encouragement, as the problem was conceded to be difficult and he said he was not familiar with textile machinery. He had been thinking over the problem, however, and the third time they called on him he said that he now thought he conld construct the required machinery. The result was the invention in 1825 of his delicate and complex automatic spinning mule in which hundreds of spindles "run themselves" with only the attention of a few unskilled helpers to watch for broken threads and mend them. This was one of the great textile inventions and has had an enormous influence on the development of the cotton industry. The next year, 1826, he went to Mülhouse in Alsace and laid the foundation of modern French cotton manufacture. Later he invented and patented a number of other important textile machines.

With the development of the railway his firm began the manufacture of locomotives. They built more than 1500 , and established a reputation equal to that of Stephenson

12 Holtzapffel: “Turning and Mechanical Manipulation," Vol. II, pp. 568, 900, 920-922. London, 1847. 
\& Company in Newcastle. The engines were built interchangeably to templates and gauges, and Roberts' works were one of the first in England to grasp and use the modern system of interchangeable manufacture.

In addition to all that has been mentioned, he invented the iron billiard table, a successful punching and shearing machine, the most powerful electro-magnet then made, a turret clock, a cigar-making machine and a system of constructing steamships and equipping them with twin screws having independent engines.

With a wonderful mechanical genius, he was lacking in worldly wisdom and was a poor business man. He severed his connection with Sharp, Roberts \& Company, became involved financially and finally died at London in 1864 in poverty. At his death a popular subscription, headed by Sir William Fairbairn and many of the nobility, was started to provide for his only daughter as a memorial of the debt which England owed him. The memoir of him in the "Transactions of the Institution of Civil Engineers" closes with the following words: "The career of Mr. Roberts was remarkable, and it should be carefully written by some one who could investigate impartially the numerous inventions and improvements to which claim could justly be laid for him, and who, at the same time, would, with equal justice, show where his inventions have been pirated." It is a great pity that this was never done.

He was a rugged, straightforward, kindly man, of great inventive power. He improved nearly everything he touched or superseded it entirely by something better, and neither his name nor his work should be forgotten. 


\section{CHAPTER VI}

\section{GEARING AND MILLWORK}

By 1830 the use of machine tools was becoming general; they were being regularly manufactured and their design was crystallizing. It was the period of architectural embellishment when no tool was complete without at least a pair of Doric columns, and planers were furnished in the Greek or Gothic style. As the first machine frames were made of wood, much of the work probably being done by cabinet makers, it was natural that they should show the same influence that furniture did. It took several generations of mechanics to work out the simpler lines of the later machines.

The application of scientific forms for gear teeth came at about this time with the general development of the machine tool. The suggestion of the use of epicyclic and involute curves is much older than most of us realize. 'The first idea of them is ascribed to Roemer, a Danish mathematician, who is said to have pointed out the advantages of the epicyclic curve in 1674. De la Hire, a Frenchman, suggested it a few years later, and went further, showing how the direction of motion might be changed by toothed wheels. On the basis of this, the invention of the bevel-gear has been attributed to him. Willis, ${ }^{1}$ however, has pointed out that he missed the essential principle of rolling cones, as the conical lantern wheel which he used was placed the wrong way, its apex pointing away from, instead of coinciding with, the

1 "'Principles of Mechanism," p. 49. London, 1841. 
intersection of the axes. De la Hire also investigated the involute and considered it equally suitable for tooth outlines. Euler, in 1760, and Kaestner, in 1771, improved the method of applying the involute, and Camus, a French mathematician, did much to crystallize the modern principles of gearing. The two who had the most influence were Camus and Robert Willis, a professor of natural philosophy in Cambridge, whose name still survives in his odontograph and tables. All of the later writers base their work on the latter's essay on "The Teeth of Wheels," which appeared originally in the second volume of the "Transactions of the Institution of Civil Engineers," 1837. Willis' "Prineiples of Mechanism," published in 1841, which included the above, laid down the general principles of mechanical motion and transmission machinery. In fact, many of the figures used in his book are found almost unchanged in the text-books of today. Smeaton is said to have first introduced cast-iron gears in 1769 at the Carron Iron Works near Glasgow, and Arkwright used iron bevels in 1775. All of these, exeept the last two, were mathematicians; and no phase of modern machinery owes more to pure theory than the gearing practice of today.

Camus gave lectures on mathematics in Paris when he was twelve years old. At an early age he had attained the highest aeademie honors in his own and foreign countries, and had become examiner of engines and professor in the Royal Academy of Arehitecture in Paris. He published a "Course of Mathematics," in the second volume of which were two books, or sections, devoted to the consideration of the teeth of wheels, by far the fullest and clearest treatment of this subject then published. These were translated separately, the first English edition appearing in London in 1806, and the 
second in $1837 .^{2}$ In these the theory of spur-, bevel-, and pin-gearing is fully developed for epicycloidal teeth. In the edition of 1837, there is an appendix by John Hawkins, the translator, which is of unusual interest. $\mathrm{He}$ gives the result of an inquiry which he made in regard to the English gear practice at that time. ${ }^{3}$ As the edition is long since out of print and to be found only in the larger libraries, we give his findings rather fully. His inquiries were addressed to the principal manufacturers of machinery in which gearing was used, and included, among others, Maudslay \& Field, Rennie, Bramah, Clement, and Sharp, Roberts \& Company. To quote Hawkins :

A painful task now presents itself, which the editor would gladly avoid, if he could do so without a dereliction of duty; namely, to declare that there is a lamentable deficiency of the knowledge of principles, and of correct practice, in a majority of those most respectable houses in forming the teeth of their wheel-work.

Some of the engineers and millwrights said that they followed Camus, and formed their teeth from the epicycloid derived from the diameter of the opposite wheel. . . .

One said, "We have no method but the rule of thumb;" another, "We thumb out the figure;" by both which expressions may be understood that they left their workmen to take their own course.

Some set one point of a pair of compasses in the center of a tooth, at the primitive circle (pitch-circle), and with the other point describe a segment of a circle for the off side of the next tooth. . . . Others set the point of the compasses at different distances from the center of the tooth, nearer or farther off; also within or without the line of centers, each according to some inexplicable notion received from his grandfather or picked up by chance. It is said inexplicable, because no tooth bounded

2 "A Treatise on the Teeth of Wheels." Translated from the French of M. Camus by John Isaac Hawkins, C.E. London, 1837.

3 Ibid., p. 175. 
at the sides by segments of circles can work together without such friction as will cause an unnecessary wearing away.

It is admitted that with a certain number of teeth of a certain proportionate length as compared with the radii, there may be a segment of a circle drawn from some center which would give "very near" a true figure to the tooth; but "very near" ought to be expunged from the vocabulary of engineers and millwrights; for that "very near" will depend on the chance of hitting the right center and right radius, according to the diameter of the wheel, and the number of teeth; against which hitting, the odds are very great indeed.

Among the Mathematical Instrument Makers, Chronometer, Clock and Watch Makers, the answers to the inquiries were, by some, "We have no rule but the eye in the formation of the teeth of our wheels;" by others, "We draw the tooth correctly on a large scale to assist the eye in judging of the figure of the small teeth;" by another, "In Lancashire, they make the teeth of watch wheels of what is called the bay leaf pattern; they are formed altogether by the eye of the workman; and they would stare at you for a simpleton to hear you talk about the epicycloidal curve." Again, "The astronomical instrument makers hold the bay leaf pattern to be too pointed a form for smooth action; they make the end of the tooth more rounding than the figure of the bay leaf."'

It is curious to observe with what accuracy the practiced eye will determine forms. . . . How important it is, then, that these Lancashire bay leaf fanciers should be furnished with pattern teeth of large dimensions cut accurately in metal or at least in cardboard; and that they should frequently study them, and compare their work with the patterns. These Lancashire workmen are called bay leaf fanciers, because they cannot be bay leaf copiers; since it is notorious that there are not two bay leaves of the same figure.

Hawkins then describes a method of generating correctly curved teeth, or rather of truing them after they had been roughly formed, devised by Mr. Saxton of 
Philadelphia, "who is justly celebrated for his excessively acute feeling of the nature and value of accuracy in mechanism; and who is reputed not to be excelled by any man in Europe or America for exquisite nicety of workmanship." By this method the faces of the teeth were milled true by a cutter, the side of which lay in a plane through the axis of a describing circle which was rolled around a pitch circle clamped to the side of the gear being cut. It is by this general method that the most accurate gears and gear cutters are formed today.

While he by no means originated the system, Hawkins seems first to have grasped the practical advantages of the involute form of teeth. Breaking away from the influence of Camus, the very authority he was translating, who seems to have controlled the thought of everyone else, Hawkins writes the following rather remarkable words : ${ }^{4}$

Since M. Camus has treated of no other curve than the epicycloid, it would appear that he considered it to supersede all others for the figure of the teeth of wheels and pinions. And the editor must candidly acknowledge that he entertained the same opinion until after the greater part of the foregoing sheets were printed off; but on critically examining the properties of the involute with a view to the better explaining of its application to the formation of the teeth of wheels and pinions, the editor has discovered advantages which had before escaped his notice, owing, perhaps, to his prejudice in favor of the epicycloid, from having, during a long life, heard it extolled above all other curves; a prejudice strengthened too by the supremacy given to it by De la Hire, Doctor Robison, Sir David Brewster, Dr. Thomas Young, Mr. Thomas Reid, Mr. Buchannan, and many others, who have, indeed, described the involute as a curve by which equable motion might be communicated from wheel to wheel, but scarce any of whom have held it up as equally eligible

4 Ibid., pp. 160 et seq. 
with the epicycloid; and owing also to his perfect conviction, resulting from strict research, that a wheel and pinion, or two wheels, accurately formed according to the epicycloidal curve, would work with the least possible degree of friction, and with the greatest durability.

But the cditor had not sufficiently adverted to the case where one wheel or pinion drives, at the same time, two or more wheels or pinions of different diameters, for which purpose the epicycloid is not perfectly applicable, because the form of the tooth of the driving wheel cannot be gcnerated by a circle equal to the radius of more than one of the driven wheels or pinions. In considering this case, he found that the involute satisfies all the conditions of perfect figure, for wheels of any sizes, to work smoothly in wheels of any other sizes; although, perhaps, not equal to the epicycloid for pinions of few leaves.

With Joseph Clement, he experimented somewhat to determine the relative end-thrust of involute and cycloidal teeth, deciding that the advantage, if any, lay with the former. He details methods of laying out involute teeth and concludes:

Before dismissing the involute it may be well to remark that what has been said respecting that curve should be considered as a mere sketch, there appearing to be many very interesting points in regard to its application in the formation of the teeth of wheels which require strict investigation and experiment.

It is the editor's intention to pursue the inquiry and should he discover a clear theory and systematic practice in the use of the involute, he shall feel himself bound to give his views to the public in a scparate treatise. He thinks he perceives a wide field, but is free to confess that his vision is as yet obscure. What he has given on the involute is more than was due from him, as editor of Camus, who treated only of the epicycloid, but the zeal of a new convert to any doctrine is not easily restrained.

So far as the writer knows this is the first real appreciation of the value of the involute curve for tooth out- 
lines, and Hawkins should be given a credit which he has not received, ${ }^{5}$ especially as he points the way, for the first time, to the possibility of a set of gears any one of which will gear correctly with any other of the set. It was thought at that time that there should be two diameters of deseribing circles used in each pair of gears, each equal to the pitch radius of the opposite wheel or pinion. This gave radial flanks for all teeth, but made the faces different for each pair. The use of a single size of describing circle throughout an entire set of cycloidal gears, whereby they could be made to gear together in any combination, was not known until a little later.

Professor Willis seems to be the first to have pointed out the proper basis of this intereliangeability in cycloidal gearing. With the clearness which characterized all his work he states: "If for a set of wheels of the same pitch a constant describing circle be taken and employed to trace those portions of the teeth which project beyond each pitch line by rolling on the exterior cireumference, and those which lie within it by rolling on its interior circumferenee, then any two wheels of this set will work correctly together. . . . The diameter of the describing circle must not be made greater than the

5 John Isaac Hawkins was a member of the Institution of Civil Engineers. He was the son of a watch and clock maker and was born at Taunton, Somersetshire, in 1772. At an early age he rent to the United States and "entered college at Jersey, Pennsylvania, as a student of medieine," but did not follow it up. He was a fine musician and had a marked aptitude for mechanies. He returned to England, traveled a great deal on the Continent, and acquired a wide experience. He was consulted frequently on all kinds of engineering activities, one of them being the attempt, in 1808, to drive a tunnel under the Thames. For many years he practiced in London as a patent agent and consulting engineer. He went to the United States again in the prosecution of some of his inventions, and died in Elizabeth, N. J., in 1865. From a Memoir in the "Transactions of the Institution of Civil Engineers,"' Vol. XXV, p. 512. 1865. 
radius of the pitch-circle of any of the wheels. . . . On the contrary, when the describing circle is less in diameter than the radius of the pitch-circle, the root of the tooth spreads, and it acquires a very strong form. . . The best rule appears to be that the diameter of the constant describing circle in a given set of wheels shall be made equal to the least radius of the set." This practice is standard for cycloidal gearing to this day. In his "Principles of Mechanism," Willis did the work on involute gearing which Hawkins set before himself; and also describes "a different mode of sizing the teeth" which had "been adopted in Manchester," for which he suggests the name "diametral pitch."

6 Willis: "Principles of Mechanism," Articles 114-116. London, 1841. See also "Transactions of the Institution of Civil Engineers," Vol. II, p. 91.

7 Diametral pitch, which is eredited to John George Bodmer, was long known as "Manchester pitch.", 


\section{CHAPTER VII}

\section{FAIRBAIRN AND BODMER}

With the improvement in machinery came improvement in millwork and power transmission. We quote in the next chapter Nasmyth's description of the millwork of his boyhood. ${ }^{1}$ Two of the mechanics most influential in the change from these conditions were Sir William Fairbairn and his younger brother, Sir Peter Fairbairn. They were born in Scotland but spent their boyhood in poverty in the neighborhood of Newcastle, in the same village with George Stephenson.

Sir William Fairbairn went to London in 1811 and obtained work with the Rennies. The shop, however, was filled with union men who set their shoulders against all outsiders. After struggling for a foothold for six weeks, he was set adrift, almost penniless, and turned his face northward. He obtained odd jobs in Hertfordshire as a millwright, and returned again to London in a few weeks, where he finally found work and remained for two years, most of the time at Mr. Penn's engine shop in Greenwich. In the spring of 1813 he worked his way through southern England and Wales to Dublin, where he spent the summer constructing nail-making machinery for a Mr. Robinson, who had determined to introduce the industry into Ireland. The machinery, however, was never set at work owing to the opposition of the workmen, and the trade left Ireland permanently.

Fairbairn went from Dublin to Liverpool and pro-

1 See page 85. 
ceeded to Manchester, the city to which Nasmyth, Roberts, Whitworth and Bodmer all gravitated. He found work with an Adam Parkinson, remaining with him for two years as a millwright, at good wages. "In those days," wrote Fairbairn, "a good millwright was a man of large resources; he was generally well educated, and could draw out his own designs and work at the lathe; he had a knowledge of mill machinery, pumps, and cranes, could turn his hand to the bench or the forge with equal adroitness and facility. If hard pressed, as was frequently the case in country places far from towns, he could devise for himself expedients which enabled him to meet special requirements, and to complete his work without assistance. This was the class of men with whom I associated in early life,-proud of their calling, fertile in resources, and aware of their value in a country where the industrial arts were rapidly developing." ${ }_{2}$

In 1817 Fairbairn and James Lillie, a shopmate, started out as general millwrights. They hired a small shed for 12 shillings a week and equipped it with a lathe of their own making, to turn shafts, and "a strong Trishman to drive it." Their first order of importance came from Mr. Adam Murray, a large cotton spinner, who took them over his mill and asked them whether they were competent to renew his main drive. They boldly replied that they were willing and able to execute the work, but were more than apprehensive when Mr. Murray told them he would call the next day and look over their workshop to satisfy himself. He came, pondered over "the nakedness of the land," "sized up" the young partners and told them to go ahead. Although a rush job, the work was done on time and so well that Murray recommended the new firm to Mr. John Kennedy, 2 “Useful Information for Engineers, Second Series," p. 212. 
the largest cotton spinner in the kingdom. For his firm, MacConnel \& Kennedy, Fairbairn \& Lillie equipped a large, new mill in 1818, which was an immediate success and at once put the struggling partners in the front rank of engineering millwrights.

"They found the machinery driven by large, square cast-iron shafts on which huge wooden drums, some of them as much as four feet in diameter, revolved at the rate of about forty revolutions a minute; and the couplings were so badly fitted that they might be heard creaking and groaning a long way off. . . . Another serious defect lay in the construction of the shafts, and in the mode of fixing the couplings, which were constantly giving way, so that a week seldom passed without one or more breaks-down.", 3

Fairbairn remedied this by the introduction of wrought-iron shafts, driven at double or treble the speed, and by improving and standardizing the design of pulleys, hangers and couplings. In the course of a few years a revolution was effected, and by 1840 the shafting speeds in textile mills had risen to from 300 to 350 revolutions per minute.

William Fairbairn's influence was felt in many ways. His treatise on "Mills and Millwork" and numerous papers before the learned societies were authoritative for many years. He improved the design of waterwheels, and was one of the first to undertake iron shipbuilding as a special industry. He established a plant at Millwall, on the Thames, "where in the course of some fourteen years he built upwards of a hundred and twenty iron ships, some of them above two thousand tons burden. It was, in fact, the first great iron shipbuilding yard in Britain." "To facilitate the building

3 Smiles: “Industrial Biography," p. 389.

4 Ibid., p. 394. 
of his iron ships he invented, about 1839, improved riveting machinery. With Robert Stephenson he built the Conway and Britannia Tubular Bridges. Probably no man in England did so much to extend the use of iron into new fields, and his formulæ for the strength of boilers, tubing, shafting, etc., were standard for years. Like Nasmyth, William Fairbairn has left an autobiography which gives a full account of his career. It is not, however, so well written or so interesting. He died in 1874 , at the age of eighty-five, loaded with every honor the nation could bestow.

His younger brother, Sir Peter Fairbairn, of Leeds, was apprenticed to a millwright while William was a journeyman mechanic in London. A few years later he became foreman in a machine shop constructing cotton machinery, and for ten years he worked in England, Scotland and on the Continent, wholly on textile machinery. In 1828 he came to Leeds, in the first flush of its manufacturing prosperity. Mr. Marshall, who had helped Matthew Murray, gave him his start and encouraged him to take over the Wellington Foundry, which, under Fairbairn's management, was for thirty years one of the greatest machine shops in England. To the manufacture of textile machinery he added that of general machinery and large tools for cutting, boring, rifling, planing and slotting. He had a great reputation in his day, but his work seems to have been more that of a builder of standard tools than an originator of new tools and methods.

Charles Holtzapffel, another well-known engineer of that generation, was the son of a German mechanic who came to London in 1787 . He received a good education, theoretical as well as practical, and became a skilled mechanician and a tool builder of wide influence. His principal book, "Turning and Mechanical Manipula- 
tion," published in 1843 in three volumes, is an admirable piece of work. Covering a field much wider than its title indicates, it is the fullest and best statement of the art at that time; and scattered through it there is a large amount of very reliable mechanical history.

By 1840 the number of men engaged in tool building was increasing rapidly, and it is impossible to consider many English tool builders who were well known and who did valuable work, such as Lewis of Manchester, B. Hick \& Son of Bolton, and others. One noteworthy man, however, ought to be mentioned-John George Bodmer, who was neither an Englishman, nor, primarily, a tool builder. ${ }^{5}$ He was a Swiss who worked in Baden and Austria, as well as in England, and his fertile ingenuity covered so many fields that a list of the subjects covered by his patents occupy six pages in the "Transactions of the Institution of Civil Engineers.',

Bodmer was born at Zurich in 1786. After serving his apprenticeship he opened a small shop for millwright work near that city. A year or so later he formed a partnership with Baron d'Eichthal and with workmen brought from St. Etienne, France, he started a factory in an old convent at St. Blaise, in the Black Forest, first for the manufacture of textile machinery and later, in 1806 , of small arms.

"Instead of confining himself to the ordinary process of ginn-making by manual labour, Mr. Bodmer invented and successfully applied a series of special machines by which the various parts-more especially those of the lock-were shaped and prepared for immediate use, so as to insure perfect uniformity and to economise labour. Amongst these machines there was also a planing machine on a small scale; and Mr. Bodmer has been

5 For a "Memoir" of Bodmer see "Transactions of the Institution of Civil Engineers,"' Vol. XXVIII, p. 573. London, 1868. 
heard to observe how strange it was that it should not have occurred to him to produce a larger machine of the same kind, with a view to its use for general purposes." He does not seem to have used the process of milling until much later. Bodmer was thus among the first to discern and to realize many of the possibilities of interchangeable manufacture, Eli Whitney having begun the manufacture of firearms on the interchangeable basis at New Haven, Conn., about 1800, only a few years before. Why Bodmer's attempt should have failed of the influence which Whitney's had is not quite clear. A possible explanation may lie in the fact that the use of limit gauges does not seem to have been a part of Bodmer's plan. This use was recognized by the American gun makers as an essential element in the interchangeable system almost from the start.

Bodmer was appointed, by the Grand Duke of Baden, director of the iron works and military inspector with the rank of captain and for a number of years much of his energy was given to the development of small arms and field artillery. He invented and built a 12-pound breech-loading cannon in 1814, which he had tested by the French artillery officers. It failed to satisfy them, and was sent a few years later to England, where it was decently buried by the Board of Ordnance.

The following year he built a flour-mill at Zurich for his brother. Instead of each set of stones being driven by a small waterwheel, all the machinery connected with the mill was driven by a single large wheel through mill gearing. The millstones were arranged in groups of four. "Each set could be started and stopped separately, and was besides furnished with a contrivance for accurately adjusting the distance between the top and bottom stones. By means of a hoist of simple construction, con-

8 Ibid., p. 576. (The italics are ours.) 
sisting in fact only of a large and broad-flanged strappulley and a rope-drum, both mounted on the same spindle (the latter being hinged at one end, so that it could be raised and lowered by means of a rope), the sacks of grain or flour conld be made to ascend and to descend at pleasure, and the operatives themselves could pass from one floor to any other by simply tightening and releasing the rope. ${ }^{7}$ The shafting of this mill was made of wrought iron, and the wheels, pulleys, hangers, pedestals, frames, \&c., of cast iron, nuch in accordance with modern practice." "s This was several years before Fairbairn and Lillie began their improvements at Manchester.

Bodmer went to England for the first time in 1816 and visited all the principal machine shops, textile mills and iron works. He returned in 1824 and again in 1833, this time remaining many years. On his second trip he established a small factory for the manufacture of textile machinery at Bolton, in which was one of the first, if not the first, traveling crane. ${ }^{9}$ At the beginning of his last and long residence in England, Bodmer appointed Sharp, Roberts \& Company makers of his improved cotton machinery, which they also undertook to recommend and introduce. This arrangement was not successful, and a few years later, in partnership with Mr. H. H. Birley, Bodmer started a machine shop and foundry in Manchester for building machinery.

Nearly all of the machinery for the Manchester plant was designed and built by Bodmer himself and it forms the subject of two remarkable patents, granted, one in 1839 and the other in $1841 .{ }^{10}$ The two patents cover in

7 Apparently the modern belt conveyor.

8 "Memoir," p. 579.

9 Ibid., p. 581.

10 The first of these is described in the American Machinist of March 13, 1902, p. 369 . 
reality nearly forty distinct inventions in machinery and tools "for cutting, planing, turning, drilling, and rolling metal," and "screwing stocks, taps and dies, and certain other tools." "Gradually, nearly the whole of these tools were actually constructed and set to work. The small lathes, the large lathes, and the planing, drilling, and slotting machines were systematically arranged in rows, according to a carefully-prepared plan; the large lathes being provided, overhead, with small traveling cranes, fitted with pulley-blocks, for the purpose of enabling the workmen more economically and conveniently to set the articles to be operated upon in the lathes, and to remove them after being finished. Small cranes were also erected in sufficient numbers within easy reach of the planing machines, \&c., besides which several lines of rails traversed the shop from end to end for the easy conveyance on trucks of the parts of machinery to be operated upon." "11 There twere, in addition to these, however, "a large radial boring machine and a wheel-cutting machine capable of taking in wheels of 15 feet in diameter, and of splendid workmanship, especially in regard to the dividing wheel, and a number of useful break or gap-lathes, were also constructed and used with advantage. It is especially necessary to mention a number of small, 6-inch, screwing lathes, which, by means of a treadle acting upon the driving gear overhead, and a double slide-rest-one of the tools moving into cut as the other was withdrawn,-screw cutting could uninterruptedly proceed both in the forward and in the backward motion of the toolslide, and therefore a given amount of work accomplished in half the time which it would occupy by the use of the ordinary 11 "Memoir," p. 588. 
means. Some of the slide-lathes were also arranged for taking simultaneously a roughing and finishing cut." ${ }^{12}$

The latter part of Bodmer's life was spent in and near Vienna, working on engines and boilers, beet sugar machinery and ordnance; and at Zurich, where he died in 1864, in his seventy-ninth year.

Bodmer does not seem to have originated any new types of machine tools, with the exception of the vertical boring-mill, which he clearly describes, terming it a "circular planer." It was little used in England, and has been considered an American development.

It is hard now to determine how far Bodmer has influenced tool design. It was much, anyway. Speaking of the patent just referred to, John Richards, who has himself done so much for tool design, says, "Here was the beginning of the practice that endured." $\mathrm{He}$ has described some of Bodmer's tools in a series of articles which show a standard of design greatly in advance of the practice of his time. ${ }^{13}$ Another writer says of Bodmer, "He seems always to have thoroughly understood the problems he undertook to solve." "One is lost in admiration at the versatility of the inventive genius which could at any one time-and that so early in the history of machine design-evolve such excellent conceptions of what was needed in so many branches of the mechanics' art." ${ }^{14}$

Bodmer was elected a member of the Institution of Civil Engineers in 1835, and his standing among his contemporaries is shown by the fact that thirty-five pages in the "Transactions" of the Institution for 1868 are given to his memoir. For a foreigner to have won

12 Ibid., p. $597-598$.

13 American Machinist, Vol. XXII, pp. 352, 379, 402, 430, 457, 478, 507, $531,559,586,607,637$.

14 Ibid., Vol. XXV, p. 369. 
respect and distinction in the fields of textile machinery, machine tools and steam engines in England, where all three originated, was surely "carrying coals to Newcastle." Not only did he succeed in these fields, but he invented the traveling crane, the chain grate for boilers, the Meyer type of cut-off valve gear, the rolling of locomotive tires, and introduced the system of diametral pitch, which was long known as the "Manchester pitch," from its having originated in his plant at Manchester.

Though Bodmer was never regularly engaged in the building of machine tools, his contribution to that field is far too great to be forgotten. 


\section{CHAPTER VIII}

\section{JAMES NASMYTH}

We know more of the life of Nasmyth than of any of the other tool builders. Not only did Smiles give an account of him in "Industrial Biography," but fortunately Nasmyth was induced in later life to write his recollections, which were published in the form of an autobiography, edited by Smiles. ${ }^{2}$ With the exception of Sir William Fairbairn, he is the only great engineer who has done this. His intimate knowledge of the rise of tool building, the distinguished part he himself had in it, and his keen and generous appreciation of others, make his record valuable. We have already quoted him in connection with Maudslay, and wherever possible will let him tell his own story.

Unlike most of the early mechanies, James Nasmyth came from a family of distinction dating from the thirteenth century. They lost their property in the wars of the Covenanters and his direct ancestors took refuge in Edinburgh, leaving their impress on the city as the architects and builders of many of its most famous and beautiful buildings. Alexander Nasmyth, the father of James, was a well-known artist; the founder of the Scotch School of Landscape Painting, and a friend of Burns, Raeburn and Sir Walter Scott. He was a landscape architect and enough of an engineer to be included

1 "Industrial Biography," Chap. XV. Boston, 1864.

2 "'James Nasmyth, Engineer, An Autobiography," edited by Samuel Smiles. London, 1883. 
in Walker's engraving of "The Eminent Men of Science Living in 1807-1808,' reproduced in Fig. 8. He invented the "bow-string" truss in 1794, the first one of which was erected over a deep ravine in the island of St. Helena, and also the setting of rivets by pressure instead of hammering. This last, by the way, was the result of trying to do a surreptitious job on Sunday without outraging the fearsome Scotch "Sawbath." Alexander Nasmyth was one of the six men on the first trip made on Dalswinton Loch, October 14, 1788, by the steamboat built by Symington for Patrick Miller. This was the second trip of a steam-propelled vessel, the first one being that of John Fitch on the Delaware, August 22,1787 . It was an iron boat with double hulls and made about five miles an hour. It barely escaped being the first iron vessel, as Wilkinson's iron boat on the Severn was launched less than a year before. The picture of this trial trip which has come down to us was made by Alexander Nasmyth at the time. ${ }^{3}$

James Nasmyth was born in 1808, the tenth in a family of eleven children. Like all of his brothers and sisters, he inherited his father's artistic tastes. If he had not been an engineer he would probably have become distinguished as an artist. He was ambidextrous, and to the end of his life his skill with his pencil was a constant source of pleasure and convenience. The notebook in which the later record of his mathematical ideas is contained, is crowded with funny little sketches, landscapes, little devils and whimsical figures running in and out among the calculations. The leaf in this book on which he made his first memorandum of the steam hammer is shown in Fig. 23. In 1817, Watt, then in his eighty-first year, visited Edinburgh and was entertained at the Earl of Buchan's, where Alexander Nasmyth met him 3 Ibid., pp. 28-31. 


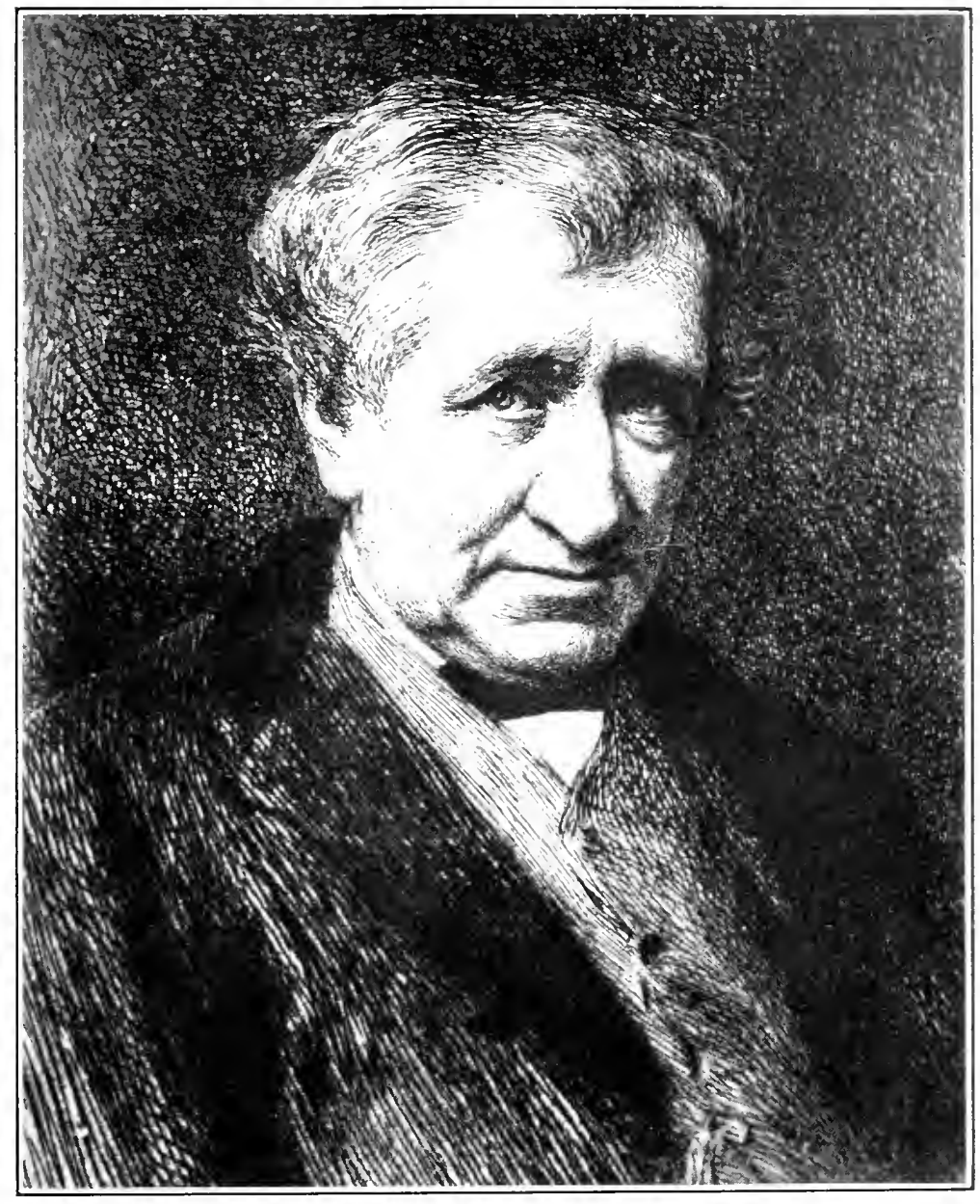

FigURE 22. JAMES NASMYTH

FROM AN ETCHING BY PACL RAJON 


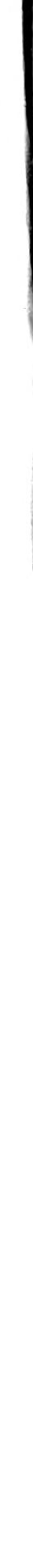


at dinner. Watt delighted all with his kindly talk, and astonished them with the extent and profundity of his information. The following day Watt visited Nasmyth to examine his artistic and other works. James Nasmyth, a nine-year-old boy, returning from school, met him at the doorstep as he was leaving, and never forgot the tall, bent figure of "the Great Engineer."

Nasmyth's father had a private workshop which was well equipped for those days. Nasmyth played there from childhood and had mastered the use of all the tools while still a schoolboy. "By means of my father's excellent foot lathe," he says, "I turned out spinning tops in eapital style, so much so that I became quite noted amongst my school companions. They would give any price for them. The peeries were turned with perfect accuracy, and the steel shod, or spinning pivot, was centered so as to correspond with the heaviest diameter at the top. They could spin twice as long as the bought peeries. When at full speed they would 'sleep' that is, turn round without a particle of waving. This was considered high art as regarded top-spinning." ${ }_{4} \mathrm{He}$ established a brisk business in these, in small brass cannon, and especially in large cellar keys, which he converted into a sort of hand cannon, with a small touchhole bored into the barrel and a sliding brass collar which allowed them to be loaded, primed, and then carriec around in the pocket.

He haunted all the shops and foundries in the neighborhood, making friends with the skilled workmen and absorbing the mysteries of foundry work, forging, hardening and tempering, and those arts which were handed down from man to man. Speaking of Patterson's old shop, Nasmyth says: "To me it was the most instructive school of practical mechanics. Although I

4 Ibid., p. 89. 
was only about thirteen at the time, I used to lend a hand, in which hearty zeal made up for want of strength. I look back on these days, especially to the Saturday afternoons spent in the workshops of this admirably conducted iron foundry, as a most important part of my education as a mechanical engineer. I did not read about such things; for words were of little use. But I saw and handled, and thus all the ideas in connection with them became permanently rooted in my mind. . . .

"One of these excellent men, with whom I was frequently brought into contact, was William Watson. $\mathrm{He}$ took special charge of all that related to the construction and repairs of steam engines, waterwheels, and millwork generally. He was a skillful designer and dranghtsman and an excellent pattern maker. His designs were drawn in a bold and distinct style, on large deal boards, and were passed into the hands of the mechanics to be translated by them into actual work."

After telling of various workmen, Násmyth says: "One of the most original characters about the foundry, however, was .Johnie Syme. He took charge of the old Boulton \& Watt steam engine, which gave motion to the machinery of the works. . . . Johnie was a complete incarnation of technical knowledge. He was the Jackof-all-trades of the establishment; and the standing counsel in every out-of-the-way case of managing and overcoming mechanical difficulties. He was the superintendent of the boring machines. In those days the boring of a steam engine cylinder was considered high art in excelsis! Patter'son's firm was celebrated for the accuracy of its boring.

"I owe Johnie Syme a special debt of gratitude, as it was he who first initiated me into that most important of all technical processes in practical mechanism-

ธIbid., p. 92. 
the art of hardening and tempering steel." ${ }^{\circ}$ From another of his friends, Tom Smith, Nasmyth picked up the rudiments of practical chemistry, as it was then understood.

Traveling with his father from time to time, he had good opportunities for meeting many distinguished engineers and of visiting the great iron works, the most "famous of which was the Carron Iron Works. "The Carron Iron Works," he writes, "are classic ground to engineers. They are associated with the memory of Roebuck, Watt, and Miller of Dalswinton. For there, Roebuck and Watt began the first working steam engine; Miller applied the steam engine to the purposes of navigation, and invented the Carronade gun. The works existed at an early period in the history of British iron manufacture. Much of the machinery continued to be of wood. Although effective in a general way it was monstrously cumbrous. It gave the idea of vast power and capability of resistance, while it was far from being so in reality. It was, however, truly imposing and impressive in its effect upon strangers. When seen partially lit up by the glowing masses of white-hot iron, with only the rays of bright sunshine gleaming through the holes in the roof, and the dark, black, smoky vaults in which the cumbrous machinery was heard rumbling away in the distance-while the moving parts were dimly seen through the murky atmosphere, mixed with the sounds of escaping steam and rushes of water; with the half-naked men darting about with masses of red-hot iron and ladles full of molten cast-iron-it made a powerful impression upon the mind."

By the time he was seventeen Nasmyth had become a skilled model maker. While he was still attending lec-

o Ibid., p. 93.

7 Ibid., p. 109, 
tures in the Edinburgh School of Arts and in the University, he had built up quite a brisk business in engine models, for which he charged $£ 10$ each. He made his brass castings in his own bedroom at night, arranging a furnace in his grate. He had a secret box of moulding sand and rammed his patterns gently so as not to awaken his father who slept below. In the morning the room would be-all clean and gave no indication that it was serving for a foundry as well as a bedroom, and by some miracle he managed to complete his practical education without burning down the house. In 1827, when he was nineteen, he built a steam road carriage which ran about the streets of Edinburgh for many months, but the condition of the Scotch roads was such as to make a machine of this kind almost useless. When he went to London he broke it up, and sold the engine and boiler for $£ 67$.

From inspecting the engines constructed by different makers, Nasmyth became impressed with the superiority of those turned out by the Carmichaels of Dundee. "I afterwards found," he writes, "that the Carmichaels were among the first of the Scottish engine makers who gave due attention to the employment of improved mechanical tools, with the object of producing accurate work with greater ease, rapidity, and economy, than could possibly be effected by the hand labor of even the most skillful workmen. I was told that the cause of the excellence of the Carmichaels' work was not only in the ability of the heads of the firm, but in their employment of the best engineers' tools. Some of their leading men had worked at Maudslay's machine shop in London, the fame of which had already reached Dundee, and Maudslay's system of employing machine tools had been imported into the northern steam factory.", These

s Ibid., p. 123. 
reports built up an ambition, which developed into a passion, to go to London and work in Maudslay's shop under "this greatest of mechanics."

Consequently, in the spring of 1829 , he went with his father to London and made application to Maudslay to work with him as an apprentice. Maudslay told them in the friendliest way, but unmistakeably, that he had had no satisfaction from gentleman apprentices and that he had definitely settled that he would never employ one again. He showed them about his shop, however, and began to melt when he saw the boy's keen interest and intelligent appreciation of everything about him. Nasmyth had brought with him some of his drawings and one of his engine models. At the end of the visit he mustered courage to ask Maudslay if he would look at them. The next day Maudslay and his partner looked them over. "I waited anxiously. Twenty long minutes passed. At last he entered the room, and from a lively expression in his countenance $I$ observed in a moment that the great object of my long cherished ambition had been attained! He expressed, in good round terms, his satisfaction at my practical ability as a workman engineer and mechanical draughtsman. Then, opening the door which led from his library into his beautiful private workshop, he said, 'This is where I wish you to work, beside me, as my assistant workman. From what I have seen, there is no need of an apprenticeship in your case."9

"Mr. Maudslay seemed at once to take me into his confidence. He treated me in the most kindly mannernot as a workman or an apprentice, but as a friend. I was an anxious listener to everything that he said; and it gave him pleasure to observe that I understood and valued his conversation. The greatest treat of all was in store for me. He showed me his exquisite collection

9 Ibid., p. 129. 
of taps and dies and screw-tackle, which he had made with the utmost care for his own service. They rested in a succession of drawers near to the bench where he worked. . .

"He proceeded to dilate upon the importance of the uniformity of screws. Some may call it an improvement, but it might almost be called a revolution in mechanical engineering which Mr. Maudslay introduced. Before his time no system had been followed in proportioning the number of threads of screws to their diameter. Every bolt and nut was thus a specialty in itself, and neither possessed nor admitted of any community with its neighbors. To such an extent had this practice been carried that all bolts and their corresponding nuts had to be specially marked as belonging to each other. . . .

"None but those who lived in the comparatively early days of machine manufacture can form an adequate idea of the annoyance, delay, and cost of this utter want of system, or can appreciate the vast services rendered to mechanical engineering by Mr. Maudslay, who was the first to introduce the practical measures necessary for its remedy.",10

There was no place in all England where Nasmyth could have learned more. He was in close personal contact with one of the best mechanics in the world. $\mathrm{He}$ had Maudslay's warmest personal interest and heard all the discussions of the engineers and famous men who used to come to the workshop. "Among Mr. Maudslay's most frequent visitors was Gen. Sir Samuel Benthan, Mr. Barton, director of the Royal Mint, Mr. Bryan Donkin, Mr. Faraday, and Mr. Chantrey, the sculptor. As Mr. Maudslay wished me to be at hand to give him any necessary assistance, I had the opportunity of 10 Ibid., pp. 131-132. 
listening to the conversation between him and these distinguished visitors. Sir Samuel Bentham called very often. He had been associated with Maudslay during the contrivance and construction of the block machinery. He was brother of the celebrated Jeremy Bentham, and he applied the same clear common sense to mechanical subjects which the other had done to legal, social and political questions.

"It was in the highest degree interesting and instructive to hear these two great pioneers in the history and application of mechanics discussing the events connected with the block-making machinery. In fact, Maudslay's connection with the subject had led to the development of most of our modern engineering tools. They may since have been somewhat altered in arrangement, but not in principle. Scarcely a week passed without a visit from the General. He sat in the beautiful workshop, where he always seemed so happy. It was a great treat to hear him and Maudslay fight their battles over again, in recounting the difficulties, both official and mechanical, over which they had so gloriously triumphed." 11

While with Maudslay, Nasmyth designed and built an index milling machine for finishing the sides of hexagon nuts. After Maudslay's death in 1831, he remained a few months with Mr. Field to finish some work in hand, and then left to start in business for himself. Nasmyth speaks in the kindliest terms of Mr. Field, and doubtless would have had more to say about him if his relationship with Maudslay had not been so close.

Joshua Field was a man to be appreciated. He was a draftsman at the Portsmouth dockyard when the block machinery was being built, and showed so clear a grasp of the work in hand that Bentham had him transferred to the Admiralty at Whitehall. In 1804 he left

11 Ibid., pp. 151-152. 
the service and went to Maudslay's, when he was at Margaret Street and employed about eighty men. $\mathrm{He}$ rose steadily, was taken into partnership in 1822, at the same time as Maudslay's eldest son, and was the senior partner after Maudslay's death when the firm was at the height of its long prosperity. He was one of those consulted in the laying of the Atlantic cable and in the designing of machinery for doing it.

"Mr. Field was one of the founders of the Institution of Civil Engineers, the origin of which was very humble. About the year 1816, Mr. Henry Robinson Palmer, who was then a pupil of the late Mr. Bryan Donkin, suggested to Mr. Field the idea of forming a society of young engineers, for their mutual improvement in mechanical and engineering science; and the earliest members were Mr. Henry Robinson Palmer, Mr. William Nicholson Maudslay, and Mr. Joshua Field. To these three were shortly added Mr. James Jones, Mr. Charles Collinge, and Mr. James Ashwell. They met occasionally in a room hired for the purpose, and to them were soon attracted others having the same objects in view. $\mathrm{Mr}$. Field was the first chairman of the Institution, being elected to that post on the sixth of January, 1818. Subsequently he became, in 1837 , a vice-president, an office he filled until he was elected president in 1848, and in 1849 , and he continued to the last to be an active member and warm supporter of the Institution." "12 Mr. Field did everything in his power to give Nasmyth a start, allowing him to make the castings for some machine tools which he proposed to finish later for use in his own plant.

Nasmyth returned to Edinburgh and took temporary quarters in a little outbuilding 16 feet by 24 feet, within a few minutes' walk of his father's home. He hired one

12 Memoir, in "'Transactions of the Institution of Civil Engineers," Vol. XXIII, p. 491. 1863. 
mechanic, Archie Torry, who remained with him the rest of his life and became one of his principal foremen. His power plant consisted of one husky laborer who turned a crank. Together they finished up the castings brought from Maudslay \& Field's; making first a lathe, then a planer 20 inches by 36 inches, and with these a few boring and drilling machines. He carried the expense of this by doing some work for an enthusiastic inventor of a wonderful rotary steam engine. Nasmyth honorably informed the inventor that his machine would not work, but as the inventor was bent on spending his money, Nasmyth executed the work for him, and the proceeds enabled him to build his machinery.

In a few months he was ready to begin. He went to Liverpool and Manchester looking for a location, and soon made many powerful friends in both cities. In 1831 he rented a single floor in Manchester, 27 feet by 130 feet, with power, and ten days later Archie followed with the tools. It was a particularly fortunate time and place for starting such an enterprise. The success of the Liverpool \& Manchester Railway, just opened, created a great demand for locomotives and for machine tools. Orders came in fast, and the planer especially was busy all the time. If its profits were anything like those of Clement's planer, it must have been a very heavy earner. As the business grew, Nasmyth added more tools, always making them himself and steadily improving their design and construction.

He soon outgrew his quarters; and in 1836 he secured land at Patricroft, a mile or so outside of the city, admirably located between the new railway and the Bridgewater Canal, and built a new plant which he called the Bridgewater Foundry. In the new foundry he used the first worm-geared tilting pouring-ladle. As it eliminated a common and very dangerous source of accidents, 
he refrained from patenting it and in a short time its use was universal. He formed a partnership with Holbrook Gaskell, who took the business end of the enterprise, and the firm of Nasmyth \& Gaskell had a very prosperous career until, sixteen years later, Mr. Gaskell was forced to retire on account of ill health.

Nasmyth built machine tools of all kinds. In 1836 he invented the shaper which was long known as "Nasmyth's Steel Arm."

Descriptions and illustrations of some of Nasmyth's tools may be found at the end of his autobiography, ${ }^{13}$ in Buchanan's "Mill Work," ${ }_{14}$ and in the American Machinist. ${ }^{15}$ He patented but few of his inventions, relying for protection mainly upon the reputation which he soon established. "In mechanical structures and contrivances," he says, "I have always endeavored to attain the desired purpose by the employment of the fewest parts, casting aside every detail not absolutely necessary, and guarding carefully against the intrusion of mere traditional forms and arrangements. The latter are apt to insinuate themselves, and to interfere with that simplicity and directness of action which is in all cases so desirable a quality in mechanical structures. Plain common sense should be apparent in the general design, as in the form and arrangement of the details; and a character of severe ntility pervade the whole, accompanied with as much attention to gracefulness of form as is consistent with the nature and purpose of the structure." 16 This was written in later life. While his later work was in thorough conformity with these principles, it was some time before he freed himself

13 p. 400 et seq.

14 Volume of Plates.

15 Oct. 14, 1909, p. 654.

16 Autobiography, p. 439. 
from the tradition of Greek style in machine frames. He was one of those, however, who led the way into the more correct practice indicated above, though he was probably not so influential in this direction as Whitworth.

His greatest invention unquestionably was that of the steam hammer, which came about in an interesting way. He had built a number of locomotives for the Great Western Railway. This railway operated a line of steamers from Bristol to New York and was planning a ship larger and faster than any then built, to be called "The Great Britain." It was to be a side-wheeler and the plans called for a large and heavy paddle shaft, 30 inches in diameter. Mr. Humphries, its designer, wrote to Nasmyth asking for help, saying so large a shaft conld not be forged with any of the hammers then in use. Nasmyth saw at once the limitations of the prevailing tilt hammer-which was simply a smith's hand hammer, enlarged, with a range so small that it "gagged" on large work, - -and that the design of large hammers must be approached in an entirely new way. "The obvious remedy was to contrive some method by which a ponderous block of iron should be lifted to a sufficient height above the object on which it was desired to strike a blow, and then to let the block fall down upon the forging, guiding it in its descent by such simple means as should give the required precision in the percussive action of the fallirg mass. Following up this idea," he writes, "I got out my 'Scheme Book,' on the pages of which I generally thought out, with the aid of pen and pencil, such mechanical adaptations as I had conceived in my mind, and was thereby enabled to render them visible. I then rapidly sketched out my steam hammer, having it all clearly before me in mind's eye. In little more than half an hour after receiving Mr. Humphries's letter narrating his unlooked-for difficulty, I had the whole con- 
trivance, in all its executant details, before me in a page of my Scheme Book, a reduced photograph copy of which I append to this description. (See Fig. 23.) The date of this first drawing was the twenty-fourth of November, $1839 . . .{ }^{\prime 17}$

"Rude and rapidly sketched out as it was, this, my first delineation of the steam hammer, will be found to comprise all the essential elements of the invention. ${ }^{18}$ Every detail of the drawing retains to this day the form and arrangement which I gave to it forty-three years ago. I believed that the steam hammer would prove practically successful; and I looked forward to its general employment in the forging of heavy masses of iron. It is no small gratification to me now, when I look over my rude and hasty first sketch, to find that $I$ hit the mark

17 Ibid., p. 240.

18 Compare Nasmyth's sketch, Fig. 23, with Fig. 24, which was taken from the model of his first hammer now in the South Kensington Museum (Exhibit No. 1571). The description of it in the catalog is as follows:

"It consists of a base plate with a large central opening through which projects the top of the anvil, so that a blow on the anvil is not transmitted to the base plate. On the plate are secured two standards which form guides for the hammer-head or tup, and also support an orerhead cylinder, the piston of which is connected with the tup by a piston rod passing through the bottom of the cylinder. Steam is admitted to this cylinder by a stop valve in the form of a slide, and then by a slide valve on the front of the cylinder, which by a hand lever can be moved so as to let steam in below the piston and so raise the heavy tup. When it is lifted to a height proportionate to the energy of the blow required, the steam is by the slide valve permitted to escape and the hammer falls upon the forging placed on the anvil. The cylinder is therefore only single-acting, but the top is closed, and a ring of holes communicating with the exhaust pipe is provided at a little distance down inside. In this way an air cushion is formed which helps to start the piston downwards when a long stroke is being taken, and also the steam below the piston is permitted to escape when the tup has been lifted as high as it can safely go. Soon after its invention the steam hammer was greatly increased in power by accelerating the fall of the tup by admitting steam above the piston in the downstroke and so changing it into the usual double-acting steam hammer."' Cat. Machinery Collection, Part II, p. 255. 

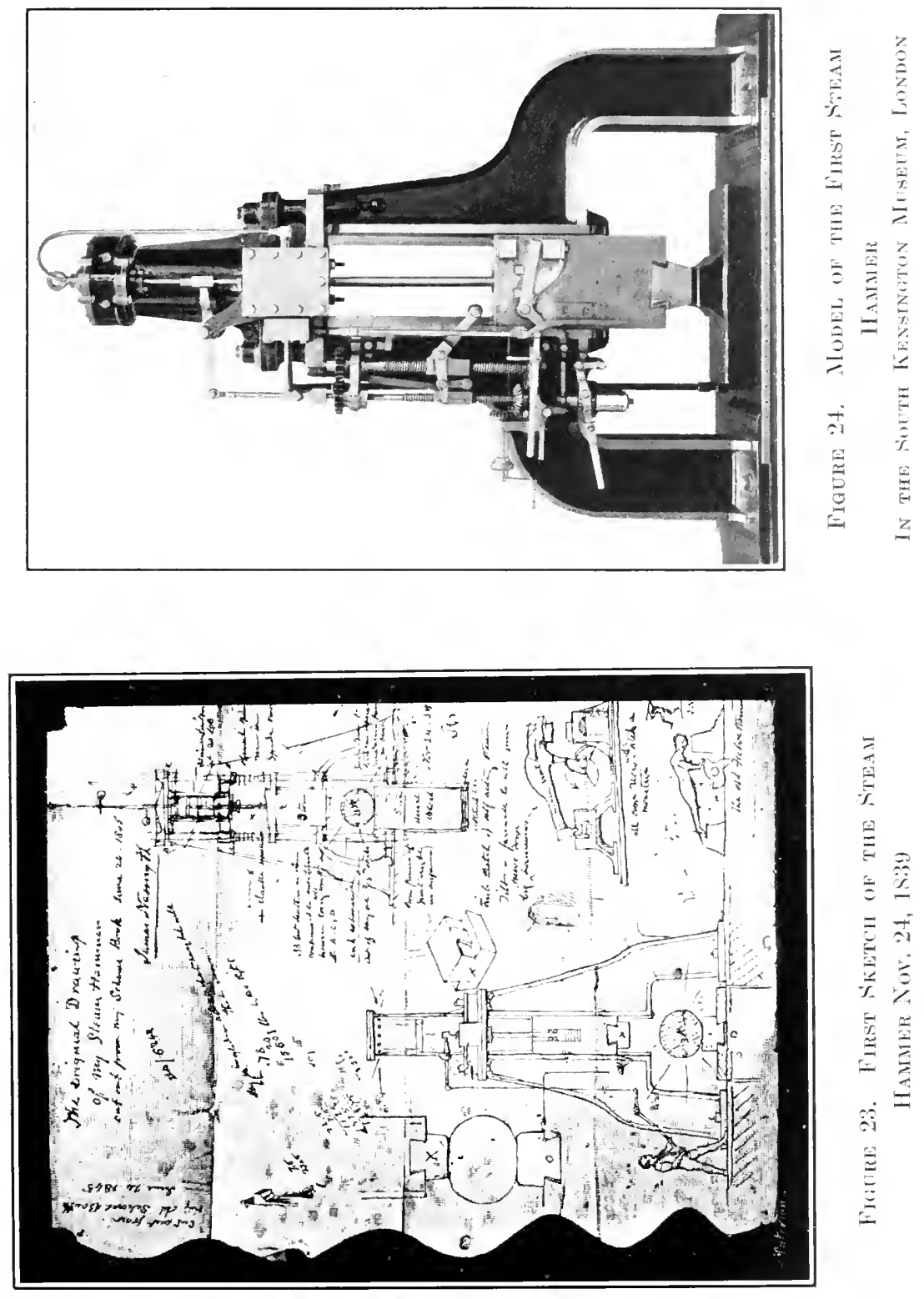


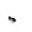


so exactly, not only in the general structure but in the details; and that the invention as I then conceived it and put it into shape, still retains its form and arrangements intact in the thousands of steam hammers that are now doing good service in the mechanical arts throughout the civilized world." ${ }^{19}$

The shaft, however, was never built. Screw propulsion was just coming into use; the design of the vessel was changed, and the whole scheme lapsed. A year or so later, M. Schneider, the French iron master of Creuzot, and his engineer, M. Bourdon, visited Bridgewater while Nasmyth happened to be away. Mr. Gaskell, after taking them about the plant, showed them the Scheme Book and pointed out the sketch of the hammer, telling them of the purpose for which it was intended. They were impressed with it and took careful notes and sketches of its details. Nasmyth was informed of their visit upon his return, but knew nothing of their having taken sketches of the hammer.

In 1842 Nasmyth visited France, and was cordially received at Creuzot and shown about the works. "On entering," he writes, "one of the things that particularly struck me was the excellence of a large wroughtiron marine engine single crank, forged with a remarkable degree of exactness in its general form. I observed also that the large eye of the crank had been punched and drifted with extraordinary smoothness and truth. I inquired of M. Bourdon 'how that crank had been forged?' His immediate reply was, 'It was forged by your steam hammer!' . . . He told me . . . that he had taken careful notes and sketches, and that among the first things he did after his return to Creuzot was to put in hand the necessary work for the erection of a steam hammer. . . . M. Bourdon conducted me to the 19 Autobiography, p. 242. 
forge department of the works, that I might, as he said, 'see my own child'; and there it was, in truth-a thumping child of my brain.",20 Fortunately it was still time to save his patent rights. He moved rapidly and in June, 1842, two months after his visit to Creuzot, a patent was obtained. ${ }^{21}$. The steam hammer soon found its way into all the large shops of the world and greatly increased Nasmyth's already comfortable fortune. Nasmyth transferred his United States patent to S. V. Merrick of Philadelphia, who introduced the hammer into the American iron works.

Besides work on the hammer and machine tools, Nasmyth made a number of inventions of interest. While still with Maudslay he invented the flexible shaft made of a coiled spring, and speaks with amusement at his finding the same idea in a dental engine many years later credited as an American invention. He invented the ball-and-socket joint for shafting hangers and also the single wedge gate valve. His steam piledriver, an adaptation of the steam hammer, was the invention in which he seems to have taken the most satisfaction. $\mathrm{He}$ was working out a method of puddling iron with a blast of steam when he was eclipsed by Bessemer's brilliant invention, in 1855, of the air blast. Nasmyth was a member of the Small Arms Committee which remodeled the Small Arms Factory at Enfield. His connection with this will be taken up in the consideration of the rise of interchangeable manufacture.

20 Ibid., pp. 246-247. The self-acting ralre motion for the steam hammer was invented by Mr. Wilson, when Nasmyth was absent on business. Wilson was manager at Patricroft and later became a partner. It was much used for a time but with the advent of balanced piston-valves the hand-operated gear supplanted it. Nasmyth's invention of the hammer was denied by M. Schneider in 1871. For fuller discussion of the history of this hammer see London Engineer, May 16, 1890, and a pamphlet by T. S. Rowlandson, entitled "History of the Steam Hammer." Manchester, 1866.

21 No. 9382, June 9, 1842. 
Nasmyth retired from business in 1856, bought an estate in Kent, and spent the remainder of his life in travel and in his studies in astronomy. He was deeply interested in this study from boyhood. Before he was twenty he had built an excellent 6 -inch reflecting telescope, and it was he who aroused Mandslay's interest in the subject. He had a 10-inch telescope at Patricroft and a large one at Hammersfield. He began his study of the moon in 1842, and received a medal for his work at the Exhibition of 1851. His book, "The Moon, Considered as a Planet, a World, and a Satellite," published in 1874, in conjunction with James Carpenter, the result of his thirty-two years of work, is authoritative today.

Nasmyth died in 1890 at the age of eighty-two. He was much more than a splendid mechanic. His personal charm and quality of mind can best be appreciated by reading his own story. This chapter will have served its purpose if it induces the reader to read the autobiography from which we have quoted so freely. 


\section{CHAPTER IX}

\section{WHITWORTH}

The work of the earlier generation of English tool builders may be said to have culminated in that of Sir Joseph Whitworth. For a man of his commanding influence, the information in regard to his life is singularly meager. He left no account of himself as Nasmyth and William Fairbairn did; no biography of him was written by his contemporaries, and the various memoirs which appeared at the time of his death are short and incomplete.

He was born at Stockport in 1803 . His father was a minister and schoolmaster. At fourteen he was placed in the office of his uncle, a cotton spinner in Derbyshire, to learn the business. But commercial work did not appeal to him. He slighted the office as much as possible and delved into every nook and corner of the manufacturing and mechanical departments of the establishment. In a few years he had mastered the construction of every machine in the place and acquired the deepseated conviction that all the machinery about him was imperfect. He ran away to Manchester to escape a routine business life, and found work with Creighton \& Company, as a working mechanic. He married in 1825, and shortly afterward went to work with Maudslay \& Field in London. Maudslay soon placed him next to John Hampson, a Yorkshireman, who was his best workman. While there, Whitworth developed his method of making accurate plane surfaces by hand 
scraping them, three at a time. On leaving Maudslay, Whitworth worked for Holtzapffel, and later for Clement. He returned to Manchester in 1833, rented a room with power, and hung out a sign, "Joseph Whitworth, Tool Maker from London." Here he began his improvements in machine tools-the lathe, planer, drilling, slotting and shaping machines. He improved Nasmyth's shaper, adding the quick-return motion, which has been known ever since as the Whitworth quick-return motion. His tools became the standard of the world, and in the London Exhibition of 1851 stood in a class by themselves.

Their preëminence lay not so much in novelty of design as in the standard of accuracy and quality of workmanship which they embodied. With unerring judgment, Whitworth had turned his attention first, to use his own words, "to the vast importance of attending to the two great elements in constructive mechanics,namely, a true plane and power of measurement. The latter cannot be attained without the former, which is, therefore, of primary importance. . . . All excellence in workmanship depends upon it."

The first step, the production of true plane surfaces, made while he was at Maudslay's, was, we are told, a self-imposed task. The method of producing these, three at a time, is generally credited to Whitworth. We have already quoted Nasmyth's statement that the method was in use at Maudslay's and that it was "a very old mechanical dodge." While this is probably true, Whitworth contributed something to the method, which very greatly increased the accuracy of the product. The writer is inclined to believe that that element was the substitution of hand scraping for grinding in the final finishing operations. Whitworth's paper,

1 Presidential Address. Institution of Mechanical Engineers, 1856, p. 125. 
read before the British Association for the Advancement of Science at Glasgow in 1840, indicates this, although it does not say so directly. In this paper he specifically points out the reason why planes should not be finished by grinding them together with abrasive powder in between; namely, that the action of the grinding powder was under no control, that there was no means of securing its equal diffusion or modifying its application and localizing its action to the particular spot which needed it. Holtzapffel confirms this view, saying, in 1847: "The entire process of grinding, although apparently good, is so fraught with uncertainty, that accurate mechanicians have long agreed that the less grinding that is employed on rectilinear works the better, and Mr. Whitworth has recently shown in the most satisfactory manner, ${ }^{2}$ that in such works grinding is entirely unnecessary, and may, with the greatest advantage be dispensed with, as the further prosecution of the scraping process is quite sufficient to lead to the limit of attainable aceuracy. . . . The author's previous experience had so fully prepared him for admission of the soundness of these views, that in his own workshop he immediately adopted the suggestion of accomplishing all accurate rectilinear works by the continuance of scraping, to the entire exclusion of grinding." 3

When Whitworth determined to make a better set of planes than any in use at the Maudslay shop, we are told that he was laughed at by Hampson and his other fellow workmen for undertaking an impossible job. He not only succeeded, but the truth of the planes he produced aroused the admiration and wonder of all who saw them. Nasmyth distinctly mentions scraping, but it should be remembered that he worked at Maudslay's

2 Referring to the paper before the British Association, 1840. 3 “'Turning and Mechanical Manipulation," Vol. II, p. 872. 
four or five years after Whitworth went there, and scraping may have been introduced into their older methods of making triple surface-plates by Whitworth, and have accounted for the wonderful accuracy of which Nasmyth speaks.

Having realized what he considered the first element in good workmanship, Whitworth began on the second,-improved methods in measurement. He introduced the system of "end measurements," relying ordinarily on the sense of touch rather than eyesight; and, for extreme accuracy, on the falling of a tumbler held by friction between two parallel planes. At the presentation of the address before the Institution of Mechanical Engineers, in 1856, he exhibited a measuring machine built on this principle which detected differences of length as small as one-millionth of an inch. The address was largely devoted to the advantages of end measurement. Referring to the machine before him, he said: "We have in this mode of measurement all the accuracy we can desire; and we find in practice in the workshop that it is easier to work to the ten-thousandth of an inch from standards of end measurements, than to one-hundredth of an inch from lines on a two-foot rule. In all cases of fitting, end measure of length should be used, instead of lines." This principle has become almost universal for commercial work, although for extremely accurate work upon final standards line measurements, aided by the microscope, are used.

It was Whitworth who brought about the standardization of screw thread practice in England. He had come into contact with the best thread practice at Maudslay's and at Clement's, but in the other shops throughout the country there was chaos, so far as any recognized standard was concerned. Using their work as a basis, and collecting and comparing all the screws obtainable, Whit- 
worth arrived at a pitch for all sizes and a thread contour, which he proposed in a paper before the Institution of Civil Engineers in 1841. ${ }^{4}$ It was received with favor, and by 1860 the "Whitworth thread" had been generally adopted throughout the country.

In 1853 Whitworth visited the United States, and in conjunction with George Wallis of the South Kensington Museum, reported on the enterprises and manufac-

4 The Minutes of the Institution, Vol. I, gice only an abstract of this paper. A recent writer, howerer, in the American Mfachinist, Vol. XLIII, p. 1178, quotes Whitworth as follows:

It is impossible to deduce a precise rule for the threads of serews from mechanical principles or from any number of experiments. On the other hand, the nature of the case is such that mere approximation would be unimportant, absolute identity of thread for a given diameter being indispensable.

There are three essential characters belonging to the serew thread, namely, pitch, depth and form. Each of these may be indefinitely modified independently of the others, and any change will more or less affect the sereral conditions of power, strength and durability. The selection of the thread is also affected by the mutual relation subsisting between the three constituent characters of pitch, depth and form. Each of these may be separately modified; but practically no one character can be determined irrespective of the others.

We find instead of that uniformity which is so desirable, a diversity so great as almost to discourage any hope of its removal. The only mode in which this could be attempted with any probability of suceess would be by a sort of compromise, all parties consenting to adopt a medium for the sake of common advantage. The average pitch and depth of the various threads used by the leading engineers would thus become the common standard, which would not only have the advantage of conciliating general concurrence, but would, in all probability, be nearer the true standard for practical purposes than any other.

An extensive collection was made of serew bolts from the principal workshops throughout England, and the average thread was earefully observed for different diameters.

(Then follows the well-known table showing the number of threads per inch.)

It will be remembered that the threads, of which the preceding table shows the arerage, are used in cast iron as well as wrought; and this circumstance has had its effect in rendering them coarser than they would have been if restricted to wrought-iron. 


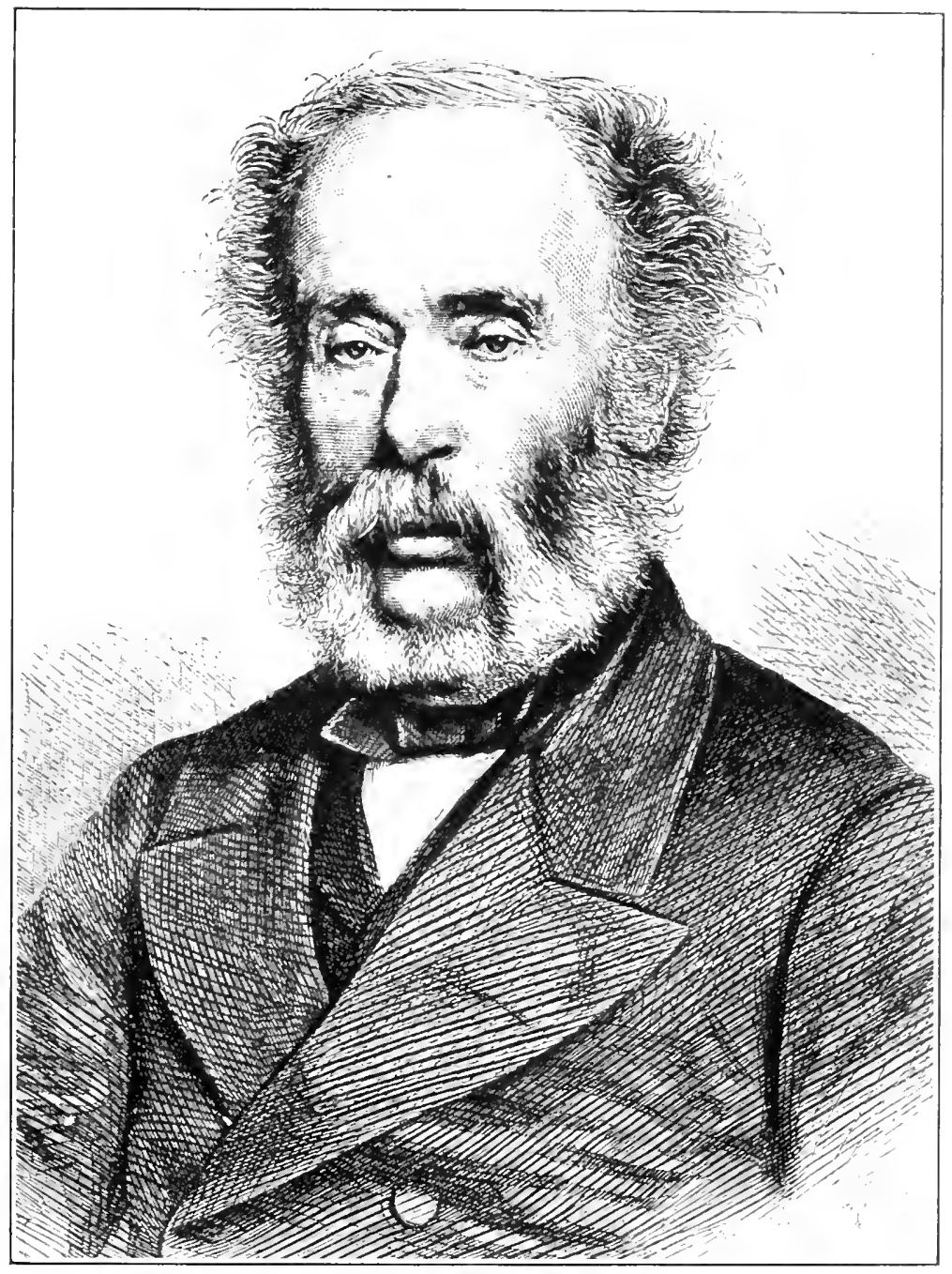

Figcre 25. Sir Joseph Whitworth 
tures of the United States. ${ }^{5}$ Nearly all the memoirs of Whitworth refer to the profound effect of this report. As one reads it today, it seems difficult to see why it should have had so much influence. It is probable that Whitworth's own personal report to the influential men about him contained much which does not appear in the formal report. In it he takes up steam engines, railway supplies, woodworking tools, electric telegraph, textile mills, and gives brief accounts of some of the factories and methods which he found at various places in New England and the Middle States. The longest description is given to the Springfield Armory, but even this is a mere fragment, and the only detailed information is of the time necessary to finish a gun-stock. We know, however, that this armory and the various private armories they saw, made an impression upon Whitworth and the whole Commission which led to the remodeling of the British gun-making plant at Enfield. Nasmyth

The variation in depth among the different specimens was found to be greater proportionately than in pitch. The angle made by the sides of the thread will afford a convenient expression for the depth. The mean of the variations of this angle in 1-in. screws was found to be about 55 deg., and this was also pretty nearly the mean of the angle in screws of different diameters. As it is for various reasons desirable that the angle should be constant, more especially with reference to general uniformity of system, the angle of $55 \mathrm{deg}$. has been adopted throughout the entire scale. A constant proportion is thus established between the depth and the pitch of the thread.

In calculating the former, a deduction is to be made for the quantity rounded off, amounting to one-third of the whole depth-that is, one-sixth from the top and one-sixth from the bottom of the thread. Making this deduction it will be found that the angle of $55 \mathrm{deg}$. gives for the actual depth rather more than three-fifths and less than two-thirds of the pitch. The precaution of rounding off is adopted to prevent the injury which the thread of the screw, and that of the taps and dies, might sustain from accident.

5 "Report of the British Commissioners to the New York Industrial Exhibition."' London, 1854. 


\section{4

was also concerned in this and a fuller account of it will be given later.

The conclusion of Whitworth's report shows clearly that he was deeply impressed with the extent to which the automatic principle was being applied to machine tools in America. "The labouring classes," he says, "are comparatively few in number, but this is counterbalanced by, and indeed, may be regarded as one of the chief causes of, the eagerness with which they call in the aid of machinery in almost every department of industry. Wherever it can be introduced as a substitute for manual labour, it is universally and willingly resorted to. . . . It is this condition of the labour market, and this eager resort to machinery wherever it can be applied, to which, under the guidance of superior education and intelligence, the remarkable prosperity of the United States is mainly due." Another characteristic of American manufacture attracted his attention,-the tendency toward standardization. In his address in 1856 he condemns the overmultiplication of sizes prevalent in every branch of English industry.

Shortly after his return from America, Whitworth was requested by the government to design a complete plant for the manufacture of muskets. He disapproved of the Enfield rifle and declined to undertake the work until exhaustive tests were made to determine the best type of rifle. The government, therefore, equipped a testing plant and range near Manchester, and Whitworth began a series of tests which showed the Enfield rifle to be inferior in almost every respect. He then submitted a new rifle, designed on the basis of his experiments, which embodied the small bore, an elongated projectile and a rapid rifle-twist and great accuracy of manufacture. Although this rifle excelled all others in accuracy, penetration and range, it was rejected by the 
war office. Some thirty years later, the Lee-Metford rifle, which embodied Whitworth's improvements, was adopted, but only after these principles had been recognized and used by every other government in Europe. His contributions to the manufacture of heavy ordnance were even greater, but they met with the same reception from the war office. In 1862 he completed a high-powered rifle cannon with a range of six miles, the proportions of which were substantially those in use today. He developed the manufacture of fluid compressed steel, about 1870 , to supply a stronger and more reliable material for ordnance use. Few men in any country have had a greater influence on the design and development of ordnance and armor. His partnership with Sir William Armstrong resulted in one of the greatest gun factories in the world.

Whitworth married twice but had no children. He acquired a great fortune. During his lifetime he established the famous Whitworth scholarships. At his death, large sums were distributed by friends, to whom he had willed them for the execution of his wishes, and they devoted nearly $£ 600,000(\$ 3,000,000)$ to the foundation or endowment of the Whitworth Institute, Owens College, and the Manchester Technical Schools, and other public institutions. In 1874 he converted his Manchester business into a stock company, giving the majority of the stock to his foremen and making provision for the acquiring of further stock by his clerks and workmen. While he was slow in receiving recognition from his own government, he became universally recognized as one of the greatest engineering authorities in the world, and was honored as few engineers have been, being elected to the Royal Society, chosen president of the Institution of Mechanical Engineers, given degrees by 


\section{ENGLISH AND AMERICAN TOOL BUILDERS}

Dublin and Oxford, the Cross of the Legion of Honor; and, in 1869, made a baronet.

As he grew older he became irritable and exceedingly dogmatic, possibly because of his long contests with slow-moving government officials. Charles T. Porter, in his autobiography, brings out this side of his nature and shows that the initiative of subordinates in his shop was practically killed. Perhaps this limited his service somewhat in his later years, but when all is taken into account, he was, without question, one of the greatest of mechanical engineers. He was a master experimenter. Tests which he made were thorough, conclusive, and always led somewhere. His experiments, whether in machine tools, screw threads, or ordnance, always resulted in a design or process which sooner or later became standard.

Whitworth's position as a tool builder is not weakened by the fact that most of the general tools had been invented by the time he began his independent work. He raised the whole art of tool building by getting at the fundamental conditions. He led the way in the change from the weak, architectural style of framing; introduced the box design or hollow frame for machinery, taking his suggestion from the human body, and very greatly increased the weight of metal used.

In 1850 Whitworth was, without doubt, the foremost tool builder in the world. He had introduced a standard of accuracy in machine tools unknown before, and so improved their design and workmanship that he dominated English tool practice for several generations. In fact, the very ascendency of Whitworth's methods seems to have been an element in the loss of England's leadership in tool building. Most of the progressive work for the next fifty years was done in America. 
In the foregoing chapters we have traced briefly the work of the great English mechanics from 1800 to 1850 . Their services to engineering, and, in fact, to mankind, cannot be measured. When they began, machine tools in any modern sense did not exist. Under their leadership nearly all of the great metal-working tools were given forms which have remained essentially unchanged. England had the unquestioned leadership in the field of machine tools. Machine-tool building in Germany and France was one or two generations behind that of England, and nearly all their machinery was imported from that country. With the exception of the early and incomplete work of the ingenious French mechanics, which we have referred to from time to time, practically all of the pioneer work was done by Englishmen.

In glancing back at these early tool builders, it will be seen that few of them were men of education. All were men of powerful minds, many of them with broad intellectual interests. It is suggestive to note one thing, whatever may be its bearing. Only three of all these men, Matthew Murray and the two Fairbairns, served a regular apprenticeship. Bentham and Brunel were naval officers; Bramah, a farmer's boy and cabinetmaker; Maudslay, a blacksmith; Clement, a slater; Roberts, a quarry laborer; Nasmyth, a clever school boy; and Whitworth, an office clerk.

Whatever may have been the reason, the rapid advance of the English machine-tool builders ceased about the middle of the last century, and they have made but few radical changes or improvements since that time. At about the same time the American engineers introduced a number of improvements of very great importance.

The great distance of America from England forced it into a situation of more or less commercial and 
mechanical independence. While France and Germany were importing machine tools from England, America began making them and soon developed independence of design. The interchangeable system of manufactures and the general use of accurate working gauges, which were hardly known in England, developed rapidly in America. These, with the introduction of the turret, the protean cam, and precision grinding machinery, and the great extension of the process of milling, served in the next fifty years to transfer the leadership in machinetool design from England to America. A visit to any one of the great machine shops in England, Germany or France will convince one that the leadership now rests with the American tool builders.

The remaining chapters will take up the lives and work of those who have contributed to this great change. 


\section{CHAPTER X}

\section{EARLY AMERICAN MECHANICS}

The phrase "Yankee ingenuity" has become a part of the English language. If New England no longer holds all the good mechanics in the United States, there was a time when she came so near it that the term "New England mechanic" had a very definite meaning over the whole country.

The industrial development of New England was long delayed, but once started it was rapid. Up to $1800 \mathrm{New}$ England artisans supplied merely small local needs and there was little or no manufacturing in any modern sense; but from then on the development was so rapid that by 1850 New England was not only supplying the United States with most of its manufactured products, but was beginning to export machinery and tools to England, where machine tools originated. For five generations, American mechanics had little or no industrial influence on Europe, and then within fifty years they began to compete on even terms.

There were several reasons for this. A market for machinery must of necessity be a wide one, for no single community, not even a large modern city, can alone support a great manufacturing enterprise. Machinery building can thrive only in a settled country having a large purchasing power and good transportation facilities. The colonies lacked all of these conditions; the people were widely scattered and poor, and there were practically no facilities for heavy transportation, at least 
by land. The colonial mechanics were often ingenious and skilled, but they had few raw materials and they could supply only their immediate neighborhood. Any approach to specialization and refinement was therefore impossible.

The second cause for delayed development was England's industrial policy toward her American colonies. The colonists had hardly gained a foothold when they began to show a manufacturing spirit and an industrial independence which aroused the apprehension of the manufacturing interests in England. The first importations of iron into England from the colonies came from Virginia and Maryland, about 1718. ${ }^{1}$ The importations for a few years thereafter are not known, as no records are available. They were sufficient, however, to arouse the jealousy of the English iron masters, for, although there was plenty of iron ore in England, they were beginning to feel seriously the shortage in wood which was then used for its reduction. They felt that the abundance of iron ore, fuel and water power in America constituted a serious menace, and they vigorously opposed the growth of any kind of manufacture in the colonies. This resulted in a prohibition of the manufacture of any form of ironware and of bar or pig iron by forges or other works. In spite of these repressive measures, a report on manufactures in the colonies, made to the House of Commons in 1731, indicated that New England had six furnaces, nineteen forges, one slitting mill and one nail factory." These could, however, have supplied only a small part of the materials required even for colonial use. By 1737 much discussion had arisen respecting the policy of encouraging importation of American iron, and petitions in favor

1 J. L. Bishop: "History of American Manufactures," Vol. I, p. 625.

2 Ibid., Vol. I, p. 623. 
of doing so were presented to Parliament. England imported at that time about 20,000 tons of foreign iron, 15,000 from Sweden and 5000 from Russia, most of which was paid for in money. ${ }^{3}$ It was urged that if this could be obtained from the colonies it could be paid for in British manufactures, at a saving of $£ 180,000$ annually. The annual production of bar iron in England was about 18,000 tons, and on account of the shortage of wood this could not be materially increased. To encourage colonial exportation of pig and bar iron to England would, it was urged, be the best means of preventing such further manufacturing as would interfere with their own. It was, therefore, proposed that a heavy duty be laid on all iron and manufactured products imported into the colonies from continental Europe, and on all iron imported into England except from America. These views prevailed and resulted in the act of 1750 , which was entitled "An act to encourage the importation of pig and bar iron from His Majesty's Plantations in America," and provided that "pig-iron made in the British Colonies in, America, may be imported, duty free, and bar-iron into the port of London; no bar-iron, so imported, to be carried coastwise, or to be landed at any other port, except for the use of his Majesty's dock yards; and not to be carried beyond ten miles from London." "With this was incorporated another clause designed to arrest all manufacture at that stage. It was enacted that "from and after the 24 th day of June, 1750, no mill, or other engine for slitting or rolling of Iron, or any plating forge to work with a tilthammer, or any furnace for making steel shall be erected, or after such erection, continued in any of his Majesty's

3 Ibid., Vol. I, p. 623.

4 Ibid., Vol. I, p. 624. 


\section{ENGLISH AND AMERICAN TOOL BUILDERS}

Colonies of America" under penalty of $£ 200 .^{5}$ This attempt to stifle the industrial life of the colonies, persistently adhered to, ultimately brought about the Revolution.

From 1730 to 1750 there had been an importation of about 2300 tons of bar iron annually, 90 per cent of which came from Maryland and Virginia, and a little less than 6 per cent from Pennsylvania. New England and New York were producing iron by that time, but were using nearly all of their product, hence their small share in the trade. The iron masters of the midland counties in England protested against this act, prophesying the utter ruin of the English iron industry. England, they said, would be rendered dependent upon the colonies, and thousands of English workmen would be reduced to want and misery; American iron could never supply the place of the Swedish iron in quality, nor the Russian iron in cheapness, consequently the manufacture of tools would be stopped and numberless families reduced to beggary.

The manufacturers of Birmingham, on the other hand, petitioned that the bill was a benefit to their trade and to the colonists, who would exchange their raw products for British manufactures; that manufacturing was more valuable to the nation than the production of raw materials, and as iron could not be produced at home in such quantity and at such price as to supply all the needs of the manufacturers, it was the duty of Parliament to encourage the importation of raw materials, even if it should arrest their production in England; that the importation of iron from America could affect the iron works no more than the same quantity from any other country, and the home production was less than one-half the amount required, and growing steadily dearer: that 5 Ibid., Vol. I, pp. 624.625. 
the increasing activity of the English manufacturers rendered it more and more necessary to obtain these materials at the lowest price, and the only way to do this was either to reduce the duty on continental iron, or make it necessary for English iron masters to reduce their prices by raising up a rival in America. They heartily concurred, however, in the prohibition of all finishing of materials as an interference with British manufactures. The merchants of Bristol petitioned that American bar iron, which was admitted only at the port of London, be imported duty free into all of His Majesty's ports. This discussion continued until 1757, when the privilege of importation was extended to the other ports of Great Britain. ${ }^{6}$

Under the act of 1750 , the importation rose to about 3250 tons, 94 per cent of which still came from Maryland, Virginia and Pennsylvania. Practically all the iron produced in New England was used there, for, despite the repressive measures from the mother country, small local manufacturing enterprises, "moonshine iron works," were constantly cropping up. The iron supply of New England came at first from the bog ores in eastern Massachusetts and Rhode Island. By 1730-1760 better mines were opened at Salisbury, Conn., and in Orange County, New York, so that the production of iron in the bog-ore regions gradually dwindled.

The Revolution terminated British legislative control over the trade and manufactures of America. The war itself furnished a market for supplies for the army, and the manufacture of cannon and guns was active. Many of these factories were ruined by the flood of imports which followed the Revolution. In 1789 the present Federal Government replaced the ineffective Confederation, which had left to the separate states the duty of

B Ibid., Vol. T, pp. 626-627. 


\section{ENGLISH AND AMERICAN TOOL BUILDERS}

protecting their manufacturing interests, and a tariff was placed upon manufactured articles. Freed from the old restrictions, and with foreign competition largely precluded, manufacturing industries began to spring up on every hand.

A third cause contributed to rapid development at this time. An enormous production of cotton followed Whitney's invention of the cotton gin in 1792, and the South, which had never been a manufacturing community, furnished both a source of supply and a rich market, easily accessible by coastwise trade. The beginnings of New England's manufacturing industries are closely identified with the rise of the American cotton crop, and most of the first machine shops were developed to manufacture textile machinery.

England, who seems to have blundered whenever she legislated on early American trade, made one more serious mistake. In 1785 Parliament passed a stringent law, with severe penalties, to stop the emigration of all mechanics and workmen in iron and steel manufactures, and to prevent not only the exportation of every description of tool, engine or machine, or parts of a machine used in making and working up iron and other materials, but even the models and plans of such machinery. England was then the most advanced of all countries in the production of engines, tools and textile machinery, and it was hoped by this act that manufacturing might be kept there. It had the opposite effect so far as America was concerned. It was inevitable that mechanics, such as Samuel Slater and William Crompton, should get away, and with them, ideas. The act only stimulated a race of skillful mechanics in America to independent development of machine tools, textile machinery, and the like. America, instead of buying her machinery from

7 Ibid., Vol. I, p. 630. 
England as she would naturally have done, proceeded to make it herself.

One of the earliest American mechanics was Joseph Jenks, who came from Hammersmith, England, to Lynn, Mass., about 1642, and died in 1683 . With the backing of Governor Winthrop, he set up an iron foundry and forge near a bog-iron mine. The very first attempt in America to start an iron works had been made in Virginia more than twenty years before, at the settlement of Jamestown. It was hardly started, however, before it was destroyed in the general sack of the settlement, and for one hundred years there was no further attempt at producing iron in Virginia. ${ }^{8}$

From the little forge and foundry started at Lynn, there is no break in the spread of iron manufacturing in this country. The forge was located on the lands of Thomas Hudson, of the same family as Hendrick Hudson, the explorer. Jenks was "the first founder who worked in brass and iron on the western continent. By his hands, the first models were made and the first castings taken of many domestic implements and iron tools." The very first casting is said to have been an iron quart pot.

For many years the colonial records refer to his various activities. He made the dies for the early Massachusetts coinage, including the famous pine-tree shilling. ${ }^{10}$ In 1646 the General Court of Massachusetts resolved that "In answer to the peticon of Joseph Jenckes, for liberty to make experience of his abilityes and Inventions for ye making of Engines for mills to go with water for ye more speedy despatch of work than formerly, and

8 Beverley: "History of Virginia." Bishop: "History of American Manufactures," Vol. I, pp. 469, 595.

9 Lewis: "History of Lynn.", 191.

10 Weeden: "Economic and Social History of New England," Vol. I, p. 
mills for ye making of Sithes and other Edged tools, with a new invented Sawe-Mill, that things may be afforded cheaper than formerly, and that for fourteen yeeres without disturbance by any others setting up like inventions; . . . this peticon is granted." "11 In 1655 he was granted a Massachusetts patent for scythes, his improvement consisting of making them long and thin, instead of short and thick, as in the old English scythe, and of welding a bar of iron upon the back to strengthen it, which later became the universal practice, ${ }^{12}$ and no radical change has been made in the blade of this implement since his day. He built for the town of Boston the first fire engine used in this country, and also made machines for drawing wire. Jenks seems to have also been interested in another iron works started at Braintree between 1645 and 1650 .

An iron works was started at Raynham in 1652 by the Leonards, who came from England about the same time as Jenks and had rorked at Lynn. ${ }^{13}$ The Jenks and Leonard families were all mechanics. It used to be said that wherever you found a Leonard you found a mechanic; and the Jenks family has been in some form of manufacturing continuously from the days of Joseph Jenks to the present time.

The near-by portions of Rhode Island and Massachusetts centering on the headwaters of Narragansett Bay, became famous for the production and manufacture of iron. A young Scotchman, Hugh Orr, settled in Bridgewater about 1738 . He was a pioneer in the manufacture of edged tools, and is said to have introduced the trip hammer into this country. "For several years he was the only edge-tool maker in this part of the coun-

11 Goodrich: "History of Pawtucket," p. 17.

12 Weeden, Vol. I, p. 184. Bishop, Vol. I, p. 477.

13 Bishop, Vol. I, p. 479. Weeden, Vol. I, p. 192. 
try, and ship-carpenters, millwrights, etc., . . . constantly resorted to him for supply. And, indeed, such was his fame, that applications were frequently made to him from the distance of twenty miles for the purpose of having an axe, an adze or an auger new tempered by his hands." In 1748, he built 500 stand-of-arms for the province, the first made in America, and later did much casting and boring of cannon during the Revolution. After the war, he made cotton machinery until his death in 1798 , at the age of eighty-two. Weeden credits Hugh Orr with being "perhaps the most conspicuous" American iron worker in the eighteenth century. His son, Robert Orr, was also a skilled mechanic, and was one of the very early master armorers of the Springfield Arsenal. ${ }^{14}$

Joseph Holmes is another of the pioneers of this neighborhood. He is said to have made more than 3000 tons of iron from bog ore, and "Holmes' iron" was famous for anchors. He also furnished many of the cannon used in the Revolution. ${ }^{15}$ The Hope Furnace at Scituate, R. I., famous for many years, was started about 1735 by Daniel Waldo. ${ }^{16}$ A nail mill was in operation at Milton, Mass., about 1740 or 1742 . Another was started at Middleboro about 1745 , on information stolen, it is said, from Milton by a mechanic disguised as a rustic. ${ }^{17}$ A mill for making scythes was in operation at Andover in 1715, and a "heavy" forge was in operation at Boston in $1720 .{ }^{18}$ Nearly all the cannon for the early American frigates were cast in and about Providence. Capt. Stephen Jenks was making arms in North Provi-

14 Weeden, Vol. II, p. 685. Bishop, Vol. I, pp. 486-487.

15 Bishop, Vol. I, p. 489.

16 Field: "State of Rhode Island and Providence Plantations," Vol. III, p. 331.

17 Weeden, Vol. II, p. 499.

18 Ibid., Vol. II, p. 498. 
dence at the beginning of the Revolution. ${ }^{19}$ An account of the early attempts in iron manufacture in Rhode Island can be found in Vol. III of Field's "State of Rhode Island and Providence Plantations."

The Jenks' influence had spread to Rhode Island as early as 1655 when Joseph Jenks, Jr., who had learned the business with his father, moved from Lynn to the headwaters of Narragansett Bay, and founded Pawtucket. He built a forge near a bog-ore mine and water power, and began making domestic utensils and iron tools. The settlement was destroyed by the Indians in 1675, during King Philip's war, but was soon rebuilt. The son of this Jenks, the third Joseph Jenks, was born there, and later became a very influential man in the colony. He was governor for five years and was interested in many of its activities. ${ }^{20}$ Providence, from its better situation commercially, early became a trading center, but nearly all the manufacturing was done at Pawtucket on account of the abundant water power. In fact, it was not until the steam engine rendered manufacturing independent of water power that Providence took the lead as an industrial center.

In the enterprises centering about Pawtucket and Providence, one finds continually the names of Jenks, Wilkinson, Brown and Greene, among the latter that of Nathaniel Greene, the Revolutionary general, who had a cannon factory at Coventry. Of these early families the Willkinsons were the most influential. Oziel Wilkinson, a Quaker, came to Pawtucket from Smithfield, R. I., established an anchor forge there in 1784, and soon became the leading man in the community. He built an air furnace in 1791, and three years later he furnished castings for the Cambridge drawbridge and for canal

19 Ibid., Vol. II, p. 793.

20 Goodrich, pp. 18.23. 
locks, probably those first used on the Merrimac River. ${ }^{21}$ He and his family had a most important part in the development of early manufacturing in America. He had six sons and four daughters. Four of the sons worked in two partnerships, one of Abraham and Isaac (twins), the other of David and Daniel. The fifth son was also a successful manufacturer. One of his daughters married Samuel Slater, who will be mentioned later; one married Timothy Greene, another, William Wilkinson, and the youngest, Hezekiah Howe, all of whom were manufacturers. The remaining son, the only child unaccounted for, died at the age of four years. ${ }^{22}$

In 1794 David Wilkinson built a steamboat and made a trip in it of three and one-half miles from Winsor's Cove to Providence. He was not impressed with the practical value of it, and dismantled it after their "frolic." Before it was destroyed, however, a young man named Daniel Leach examined it carefully with the greatest interest. Later, when Fulton made his plans for the "Clermont," the drawings were said to have been made by this same man, Leach. ${ }^{23}$

In 1797 David Wilkinson invented a slide lathe which was patented the next year. The writer has not been able to obtain an accurate description of this. The most direct reference to it is a letter of Samuel Greene to Zachariah Allen, a prominent Rhode Island cotton manufacturer, dated June 17, 1861, which says: "I suppose David Wilkinson to be the inventor of the slide lathe, at first applied to the making of large press screws, for which I believe he got a patent. I know he made appli-

21 Ibid., p. 51.

22 Israel Wilkinson: "Memoirs of the Wilkinson Family," pp. 220. 461. Jacksonville, Ill., 1869.

23 Ibid., pp. 509-513; also, Field, Vol. III, p. 372. The name here is given as French. 
cation to the British Goverument, and I have heard said did get a grant." The patent ran out before the lathe came into general use. Fifty years later Congress voted Wilkinson $\$ 10,000$ "for benefits accruing to the public service for the use of the principle of the gauge and sliding lathe, of which he was the inventor." ${ }_{24} \mathrm{He}$ seems to have been working on it in America at the same time as Maudslay in London. ${ }^{25}$ Sylvanus Brown, who helped Slater build the first Arkwright cotton machinery at Pawtucket, is also said to have invented the slide lathe still earlier (in 1791) and to have also used it for cutting wrought-iron screws for sperm-oil presses. ${ }^{26}$ There are good records of Maudslay's slide lathes; in fact, screwcutting lathes made by him prior to 1800 are in the South Kensington Museum at London. Priority can hardly be claimed for these American lathes until something more is known of them, and whether they were the equal of Maudslay's in design and quality.

The Wilkinsons were closely identified with the early textile enterprises. As the gun industry developed the interchangeable system, so the cotton industry developed the American general machine tool. At the close of the Revolution, many attempts were made to start textile industries, by Orr in 1786, Cabot at Beverly in 1787, and Anthony at Providence in 1788, and also at Worcester. A man named Alexander is said to have operated the first loom with the flying shuttle in America, which was later moved to Pawtucket. Moses Brown,

24 The Senate Committee which recommended this action consisted of Rusk of Texas, Cass of Michigan, Davis of Mississippi, Dix of New York, and Benton of Missouri. The bill passed the Senate in June, and the House in August, 1848.

25 "Memoirs of the Wilkinson Family," pp. 506-508, 518. Goodrich, p. 51 .

26 Goodrich, p. 48. 
about 1790, imported a few spinning frames to Providence, but they proved a failure.

Samuel Slater, who married Wilkinson's daughter, was an Englishman who had served his time with Arkwright and Strutt, and had become thoroughly familiar with the Arkwright machinery. In 1789 he had emigrated to America with the purpose of starting a textile industry. We have already mentioned the embargo which England placed on mechanics and on all kinds of machinery. This had compelled Slater to use the greatest caution in leaving the country. Disguised, it is said, as a rustic, he went to London and sailed from there, giving no indication of his plans until after he had gone, when he had a letter sent to his family. He went first to Philadelphia, but hearing of Moses Brown's attempts at spinning in Providence, he wrote to Brown and made arrangements to go to Pawtucket and reproduce for him the Arkwright machinery. Slater was at that time only twenty years old. After a winter of hard work he succeeded in making several frames with a total of seventytwo spindles, and two carding machines. These were started in a small building, later known as the Old Slater Mill, with an old negro named "Primus" Jenks as motive power. During this winter Slater lived in the family of Oziel Wilkinson and married his daughter. The second mill was started in 1799 by Oziel Wilkinson and his three sons-in-law, Slater, Greene and Wilkinson. ${ }^{27}$

Doctor Dwight, in his travels, in $1810,{ }^{28}$ writes of Pawtucket:

"There is probably no spot in New England of the same extent, in which the same quantity or variety of manufacturing business is carried on. In the year 1796, there were here three anchor forges, one tanning mill,

27 Ibid., pp. 39-51.

28 Vol. II, pp. 27-28. 
one flouring mill, one slitting mill, three snuff mills, one oil mill, three fulling mills, a clothier's works, one cotton factory, two machines for cutting nails, one furnace for casting hollow ware-all moved by water-one machine for cutting screws, moved by a horse, and several forges for smith's work." This was long before Lowell, Lawrence and Manchester had come into existence.

The Wilkinsons were interested in other things as well as in the cotton industries. David established a shop and foundry in Pawtucket, where for one thing he made cannon which he bored by an improved method consisting of "making his drill and bore stationary and having the cannon revolve about the drill." He built textile machinery for almost every part of the country, from northern New England to Louisiana, and made the machinery used at New Bedford and other whaling ports for pressing sperm oil. ${ }^{29}$ About 1816 David and Daniel Wilkinson bought out a man named Dwight Fisher and manufactured nails until 1829, their output being about 4000 pounds daily. ${ }^{30}$ In 1829 David Wilkinson moved to Cohoes, N. Y., and with DeWitt Clinton, Stephen Van Rensselaer and others, started the textile industries in that city. ${ }^{31}$ In 1832 Zebulon White started up one of the abondoned Wilkinson furnaces, which three years later was known as the Pawtucket Cupola Furnace Company. This afterwards became the firm of J. S. White \& Company. ${ }^{32}$

Oziel Wilkinson died in 1815, but the influence of the Wilkinson family continued for many years. Slater steadily widened his operations and was so influential in laying the foundations of the textile industry that he

29 Goodrich, p. 69.

30 Field: "Rhode Island and Providence Plantations," Vol. III, p. 373. 31 Van Slyck: "Representatives of New England Manufacturers," p. 515. 32 Field, Vol. III, p. 372. 


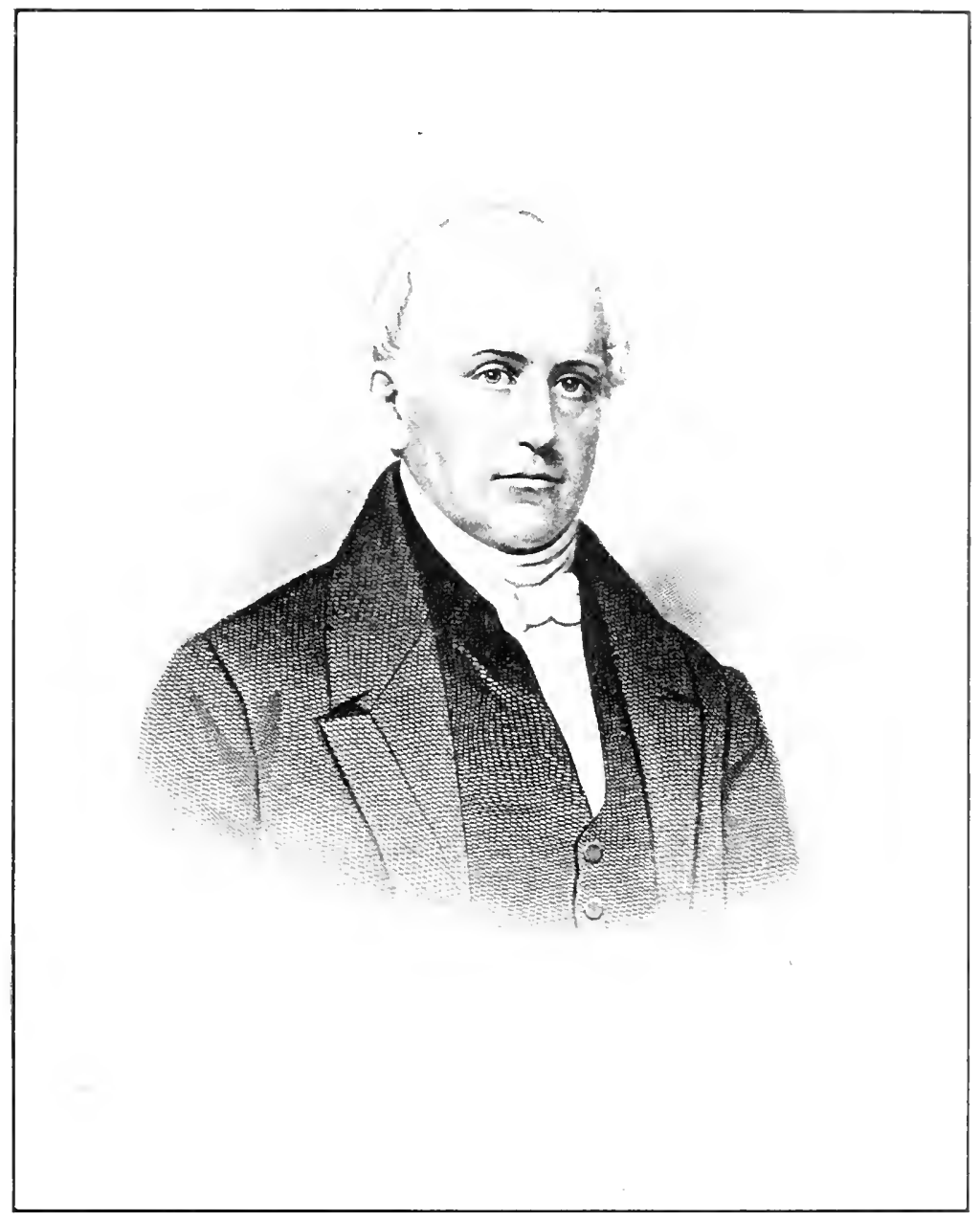

Figure 26. Samuel sitater 

became known as "the father of the American cotton industry." How rapidly the cotton industry spread is shown by a memorial to Congress in 1815 , stating that there were 140 cotton manufactures within thirty miles of Providence, employing 26,000 hands and operating 130,000 spindles. $^{33}$ Only a few of the more important ramifications can be given.

In 1822 Samuel Slater, Larned Pitcher and three others bought a little two-story building at what was then Goffstown, on the Merrimac River, and founded the great Amoskeag Manufacturing Company, and the eity of Manchester, N. H. It is now known as the greatest textile mill in the world, but the company's original charter was very broad, and, in addition to its other interests, the company operated for many years one of the largest and most influential machine shops in the country, where were built locomotives, engines, boilers, all kinds of textile machinery, machine tools and mill machinery.

Alfred Jenks, who learned his trade under Slater, moved to Holmesburg, near Philadelphia, in 1810, taking with him drawings of every variety of cotton machinery, as far as it had then advanced, and commenced its manufacture. ${ }^{34}$ He furnished the machinery for the first cotton mill in that portion of Pennsylvania and for the first woolen mill in the entire state, and developed what was for many years one of the most important plants for the building of textile machinery in the United States.

Eleazer Jenks built a machine shop at Pawtucket in 1813 for heavy forging and for the manufacture of spinning machinery, which was occupied by David Wilkinson for many years. ${ }^{35}$ The same year, Larned Pitcher also

33 Bishop, Vol. II, p. 214.

34 Ibid., Vol. III, p. 18.

35 Goodrich, p. 64. 


\section{ENGLISH AND AMERICAN TOOL BUILDERS}

started a shop there, and soon took in P. Hovey and Asa Arnold. In 1819 Ira Gay was taken in, and the firm became Pitcher \& Gay, one of the largest manufacturers of cotton machinery. Gay remained in Pawtucket until 1824, when he went to New Hampshire in connection with the Amoskeag Manufacturing Company and the Nashua Manufacturing Company, then just starting. ${ }^{36}$ A few years later Ira Gay and Zeba, his brother, started a shop at North Chelmsford for building textile machinery. With the growth of the Merrimac textile interests, this plant became very influential and is running today. The firm has changed several times with the deaths of various partners, and is now known as the North Chelmsford Machine \& Supply Company. It has preserved many of the old tools used in the early days, and there are few shops of greater historical interest in this country.

Capt. James S. Brown, son of the Sylvanus Brown referred to, who had worked for David Wilkinson in 1817, succeeded Ira Gay in the Pawtucket shop, the firm becoming Pitcher \& Brown. In 1842 Brown became sole owner and greatly enlarged the works. The shop which he built in 1847 was 400 feet long and employed over 300 workmen. Brown lived for many years and made many valuable inventions, which included a beveled gear cutter, boring machine, grinder, improvement in the Blanchard type of lathe, and many improvements in textile machinery. Some of the lathes which he himself built in 1820 were in use for seventy years. ${ }^{37}$

Col. Stephen Jenks started a shop in 1820 for the making of nuts and screws, which later became the William H. Haskell Company of Pawtucket. Alvin Jenks,

36 Ibid., p. 66.

37 Ibid., pp. 71-72. 
of Stephen Jenks \& Sons, went to Central Falls in 1829 and the next year entered into partnership with David G. Fales. This firm, known as Fales, Jenks \& Company, built cotton machinery for many years, and moved to Pawtucket in $1865 .^{38}$ The Jenkses of the Fales \& Jenks Machine Company, as it is known now, are lineal descendants of the original Joseph Jenks of Lynn.

In 1834 Jeremiah O. Arnold, who as a young man worked for David Wilkinson, and his brother, Joseph Arnold, started in Pawtucket the first press for making nuts. Later, Joseph Arnold retired and William Field took his place, the firm becoming William Field \& Company. They moved to Providence in 1846, and in 1847 became the Providence Tool Company. ${ }^{39}$ The Providence Forge \& Nut Company was organized by some men from the Tool Company in 1852, and a plant was built. Four years later the new venture was absorbed by the parent company, which moved to the new plant. The Providence Tool Company had a wide influence for many years, manufacturing the Household sewing machine and the Martini rifle, as well as a line of tools. In 1883 it was reorganized and became the present Rhode Island Tool Company.

The Franklin Machine Company was started by Stanford Newell, Isaac Thurber and others, about 1800. The plant was always referred to in the old records as "The Cupoia." During the War of 1812 it was busy making cannon under the charge of Isaac Wilkinson, one of Oziel's sons, who was then a boy only seventeen years old. ${ }^{40}$ The Builders Iron Foundry, formerly known as "The High Street Furnace," began business some time prior to 1820. The American Screw Company had its

38 Ibid., p. 72. Also, Field, Vol. III, p. 373.

39 Goodrich, p. 75.

40 Field, Vol. III, p. 375. 
beginning in the Eagle Screw Company, organized in 1838 under the leadership of William G. Angell. Hampered by serious litigation and sharp competition, it continued with indifferent success until 1849, when $\mathrm{Mr}$. Angell, adopting a machine invented by Thomas J. Sloan of New York, brought out the pointed screw. The New England Screw Company, whose inventor, Cullen Whipple, had come from the earlier Providence Screw Company, united with the Eagle Screw Company in 1860, forming the present American Screw Company.

The Corliss Machine Works were started in 1848.

Brown \& Sharpe, the most important and influential of all the Providence plants, was established in 1833 by David Brown and his son, Joseph R. Brown. The history of this company is so important that it will be taken up in a separate chapter.

One can hardly turn from the history of manufactures in Providence without some reference to the manufacturing of jewelry. A Cyril Dodge made silver shoe buckles "two doors north of the Baptist meeting-house" about the time of the Revolution, but the first real manufacturer of jewelry in Providence was Nehemiah Dodge, who, just after the Revolution, started in a little shop on North Main Street as a goldsmith and watchmaker. $\mathrm{He}$ also made necklaces, rings and miniature cases. Dodge lived to be over ninety years old and to see the industry spread wonderfully. By 1805 there were three other jewelers, one of whom, by the way, was a Jenks, and they employed all told about thirty workmen. In 1810 there were 100 workmen; in 1815, 175; and in 1832, 282. The census writers of 1860 give eightysix shops with 1761 workmen; in 1880, 148 shops with 3264 employees, and in 1890 there were 170 shops employing 4380. These figures cover Providence only. Many other shops were located in near-by towns. These 
were all small and tended to multiply. The journeymen were the highest paid artisans anywhere about, earning from $\$ 5$ to $\$ 10$ a day, and two or three were constantly setting up for themselves. The oldest jewelry firm in or about Providence is said to be the Gorham Manufacturing Company now located in the suburb of Elmwood. Jabez Gorham, its founder, was first engaged as a jeweler with four others about 1813 . In 1831 he formed a partnership with H. L. Webster, a journeyman silversmith from Boston, and specialized on the making of silver spoons, thus starting the Gorham Manufacturing Company. ${ }^{41}$ Palmer \& Capron, another old firm, was founded about 1840 .

There were other early centers of mechanical influence. With the invention of steam navigation, New York became a center of engine building for the steamboat trade, and the Allaire, Quintard, Fletcher, Delamater, and other works, were well known many years ago, but for some reason New York City has never been conspicuous for tool building, the Garvin Machine Company being the only large firm in this field. Worcester, Hartford, Philadelphia and Windsor, Vt. (small and secluded as it is), have contributed signally to tool building throughout this country and Europe, and will be taken up later. We have considered Pawtucket first, because it was the earliest center and because its wide influence in building up other centers is little realized. The extensive water power available in the Merrimac Valley gave rise to the great textile interests of Manchester, Lowell and Lawrence, which have far outstripped those centered about Pawtucket, but the textile industry began in Pawtucket and with it the building of machinery and tools.

41 Ibid., Vol. III, pp. 377-381. 


\section{CHAPTER XI}

\section{THE RISE OF INTERCHANGEABLE MANUFACTURE}

It is well, in beginning, to define what we mean by the interchangeable system. We will consider it as the art of producing complete machines or mechanisms, the corresponding parts of which are so nearly alike that any part may be fitted into any of the giren mechanisms. So considered, it does not include the manufacture of separate articles, closely like each other, but which do not fit together permanently into a mechanism. If this were meant, the work of the early typefounders would clearly antedate that of the modern manufacturers, as they produced printing types by the process of casting which were similar to each other within very close limits. There is, however, a wide difference between this and the parts in such a mechanism as a gun, for individual types are not permanently articulated.

The interchangeable system was developed by gun makers. It is commercially applicable chiefly to articles of a high grade, made in large numbers, and in which interchangeability is desirable. Of the typical articles, such as firearms, bicycles, typewriters, sewing machines, and the like, now produced by the interchangeable system, guns and pistols are the only ones which antedate the system itself. These were used in great numbers, and in military arms especially interchangeability was of the highest value. Under the old system with hand-made muskets, in which each part was fitted to its neighbors, 
the loss or injury of a single important part put the whole gun out of use until it could be repaired by an expert gunsmith. Eli Whitney, in a letter to the War Department in 1812, stated that the British Government had on hand over 200,000 stands of muskets, partially finished or awaiting repairs. ${ }^{1}$ The desirability, therefore, of some system of manufacture by which all the parts could be standardized and interchangeable, was well recognized. There existed a demand for military arms which could meet this condition, but it was felt at the time that it was impossible to meet it.

The system of interchangeable manufacture is generally considered to be of American origin. In fact, for many years it was known in Europe as the "American System" of manufacture. If priority be assigned to the source which first made it successful, it is American; but the first suggestions of the system came from France. We have already seen that the French mechanics were the first to work upon many of the great mechanical improvements; but here, as in the case of the slide-rest and planer, they seem to have caught the idea only. It was left to others to make it a practical success.

At least two attempts were made to manufacture guns interchangeably in France, one in 1717, the other in 1785. Of the first we know little. Fitch, in his "Report on the Manufactures of Interchangeable Mechanisms," in the United States census of 1880 , speaks of it, but says it was a failure. ${ }^{2}$ We know of the second from an interesting and surprising source. Thomas Jefferson, while Minister to France, wrote a letter to John Jay, dated August 30, 1785, which contains the following:

An improvement is made here in the construction of muskets, which it may be interesting to Congress to know, should

1 Blake: "History of Hamden, Conn.," p. 133.

2 p. 2. 
they at any time propose to procure any. It consists in the making every part of them so exactly alike, that what belongs to any one, may be used for every other musket in the magazine. The government here has examined and approved the method, and is establishing a large manufactory for the purpose of putting it into execution. As yet, the inventor has only completed the lock of the musket, on this plan. He will proceed immediately to have the barrel, stock, and other parts, executed in the same way. Supposing it might be useful in the United States, I went to the workman. He presented me the parts of fifty locks taken to pieces, and arranged in compartments. I put several together myself, taking pieces at hazard as they came to hand, and they fitted in the most perfect manner. The advantages of this, when arms need repair, are evident. He effects it by tools of his own contrivance, which, at the same time, abridge the work, so that he thinks he shall be able to furnish the musket two livres cheaper than the common price. But it will be two or three years before he will be able to furnish any quantity. I mention it now, as it may have an influence on the plan for furnishing our magazines with this arm. ${ }^{3}$

Six months later he wrote a letter to the governor of Virginia, which is almost a copy of this one. In another letter written many years later to James Monroe, Jefferson gives the name of this mechanic as Le Blanc, saying that he had extended his system to the barrel, mounting and stock, and stating: "I endeavored to get the U. S. to bring him over, which he was ready for on moderate terms. I failed and I do not know what became of him.", We wish to give full credit to this genius who seems to have caught a clear idea of some at least of the principles involved, those of interchangeability and the substitution of machine work for hand work. The

3 "The Writings of Thomas Jefferson," Edited by H. A. Washington, Vol. I, p. 411. New York, 1853.

4 "The Writings of Thomas Jefferson," Edited by Paul L. Ford, Vol. VIII, p. 101. New York, 1887. 
account makes no mention of gauges or of the division of labor, but this might easily have been due to Jefferson's unfamiliarity with the details of manufacture.

We have seen in a previous chapter that a close approach to the interchangeable system was made in the Portsmouth block machinery of Bentham and Brunel. This was rather an application of modern manufacturing principles than a specific case of interchangeable manufacture. The interchangeability of product obtained was incidental to good manufacturing methods, not a distinct object aimed at, and there does not seem to have been any system of gauging during the processes of manufacture, to insure maintaining the various parts within specified limits of accuracy. In fact, the output itself did not require it, as ship's blocks do not call for anything like the precision necessary in guns or the other typical products of the interchangeable system.

We have seen, too, that John George Bodmer began about 1806 to manufacture guns at St. Blaise in the Black Forest, using special machinery for much of the work previously done by hand, especially for the parts of the lock, which "were shaped and prepared for immediate use, so as to insure perfect uniformity and economize labor." In both of these instances, the Portsmouth block machinery and the St. Blaise factory, definite steps which form part of the interchangeable system were taken, but it does not seem probable that the system existed in anything like the completeness with which it was being developed at that time in America.

In 1798 and 1799 two contracts were let by the United States Government for firearms, one to Eli Whitney in 1798, the other to Simeon North in 1799. These contracts are of the greatest importance. Whitney had invented the cotton gin in 1792. This invention, as is well known, had a profound economic effect on the whole 


\section{ENGLISH AND AMERICAN TOOL BUILDERS}

civilized world, but the condition of the patent laws at that time and the very value of the invention itself made it impossible for him to defend his rights; and, although he had practically created a vast industry, he actually lost more money by the invention than he gained. By 1798 he made up his mind that he must turn to something else. He chose the manufacture of muskets, and addressed a letter to Oliver Wolcott, Secretary of the Treasury, in which he said:

I should like to undertake the manufacture of ten to fifteen thousand stand of arms. I am persuaded that machinery moved by water, adapted to this business would greatly diminish the labor and greatly facilitate the manufacture of this article. Machines for forging, rolling, floating, boring, grinding, polishing, etc., may all be made use of to advantage. ${ }^{5}$

His contract of 1798 resulted. From the very start Whitney proposed to manufacture these arms on a "new principle." He built a mill at Whitneyville, just outside of the city of New Haven, utilizing a small water power. Nearly two years were required to get the plant into operation, as he had to design and build all of his proposed machinery. In 1812 when making application for another contract for 15,000 muskets, Whitney writes :

The subscriber begs leave further to remark that he has for the last 12 years been engaged in manufacturing muskets; that he now has the most respectable private establishment in the United States for carrying on this important branch of business. That this establishment was commenced and has been carried on upon a plan which is unknown in Europe, and the great leading object of which is to substitute correct and effective operations of machinery for that skill of the artist which is acquired only by long practice and experience; a spccies of skill

5 "New Haven Colony Historical Society Papers," Vol. V, p. 117. 
which is not possessed in this country to any considerable extent. $^{6}$

In another place it is stated that the object at which he aimed and which he accomplished was "to make the same parts of different guns, as the locks, for example, as much like each other as the successive impressions of a copper-plate engraving. "ז

Mr. Whitney's determination to introduce this system of manufacturing was ridiculed and laughed at by the French and English ordnance officers to whom he explained it. They said that by his system every arm would be a model and that arms so made would cost enormously. Even the Washington officials were skeptical and became uneasy at advancing so much money without a single gun having been completed, and Whitney went to Washington, taking with him ten pieces of each part of a musket. He exhibited these to the Secretary of War and the army officers interested, as a succession of piles of different parts. Selecting indiscriminately from each of the piles, he put together ten muskets, an achievement which was looked on with amazement. We have not the exact date of this occurrence, but it was probably about $1800 .{ }^{8}$

Meantime Simeon North, who unlike Whitney was a gun maker by trade, had completed his first contract for 1500 pistols, and had executed a number of others. In these no mention was made of interchangeability, but whether independently or not, he very soon began to develop the same methods as Whitney. In a letter to the Secretary of the Navy in 1808, North says:

6 Ibid., p. 122.

7 Denison Olmstead: “Memoir of Fli Whitney,'” p. 50. 1846.

8 Blake: "History of Handen, Conn.," p. 138. 
I find that by confining a workman to one particular limb of the pistol untill he has made two thousand, I save at least one quarter of his labour, to what I should provided I finishd them by small quantities; and the work will be as much better as it is quicker made. ${ }^{9}$

He also says in the same letter:

I have some seventeen thousand screws \& other parts of pistols now forgd. \& many parts nearly finished \& the business is going on brisk and lively.

Here is clearly the principle of subdivision of labor and the beginning of the standardizing of parts. In 1813 North contracted to furnish 20,000 pistols. This agreement contained the following significant clause:

The component parts of the pistols are to correspond so exactly that any limb or part of one Pistol may be fitted to any other Pistol of the Twenty thousand. ${ }^{10}$

It is stated in the valuable memoir of Simeon North, by his great-grandsons, that this is the first government contract in which the contractor agreed to produce arms having interchangeable parts, and it is consequently claimed for Colonel North that he originated this process.

We have not had an opportunity to examine the official records in Washington in regard to Mr. Whitney's dealings, but it is quite clear from his letter of 1812 that he had been operating on this basis for nearly ten years, although it may not have been formally recognized in his contracts with the Government. Capt. Decius Wadsworth, then inspector of muskets, wrote to the Secretary of the Treasury in 1800 as follows:

9 S. N. D. and R. H. North: "Memoir of Simeon North," p. 64. 1913. 10 Ibid., p. 81. 
But where the different parts of the lock are each formed and fashioned successively by a proper machine, and by the same hand, they will be found to differ so insensibly that the similar parts of different locks may be mutually substituted. The extending of this principle to all parts of a musket has been a favorite idea with Mr. Whitney from the beginning. It has been treated and ridiculed as a vain and impracticable attempt by almost all those who pretended to superior knowledge and experience in the business. He has the satisfaction, however, now of shewing the practicability of the attempt. Although I am of the opinion that there is more to please the imagination than of real utility in the plan, yet as it affords an incalculable proof of his superior skill as a workmau, and is what I believe has never been attempted with success before, it is deserving of much consideration. ${ }^{11}$

Furthermore, Jefferson, in the letter to Monroe written in 1801, says in speaking of Whitney:

$\mathrm{He}$ has invented molds and machines for making all the pieces of his locks so exactly equal, that take 100 locks to pieces and mingle their parts and the 100 locks may be put together by taking the pieces which come to hand. ${ }^{12}$

In a letter to the Secretary of War in June, 1801, Whitney writes: ". . . my system and plan of operations are, I believe, entirely new and different from those heretofore pursued in this or any other country.

"It was the understanding and expectation of the Secretary of the Treasury, with whom I contracted, that I should establish a manufactory on the principles which were then pointed out and explained to him. This system has been uniformly pursued from the beginning."

It would seem that the stipulation in North's contract of 1813 was not so much the beginning of a new method

11 Blake, p. 296.

12 See note 4 , page 130 .

13 Blake, p. 300. 
as a recognition of methods which had already come into existence. It seems almost inevitable that the two men, pioneer manufacturers and government contractors in closely allied industries, and located but twenty miles apart, must have known more or less of each other's work and have been influenced by each other's methods. Without trying to differentiate the credit between them too closely it is quite certain that in the work of these two men the interchangeable system had its birth. Colonel North's work for the Government was invariably well done, and for more than fifty years he continued to supply, first pistols, and later rifles for the army and navy. Of the two, Whitney had the greater influence in spreading the interchangeable system throughout the country. He was well known and influential through his invention of the cotton gin and was located in a larger center. He was called upon by the Government for advice, and at its request sent to Springfield some of his best workmen to introduce his system there, and also help to start it at Harper's Ferry. Whitney built his factory in 1798 or 1800 , and employed at the start about sixty men. Colonel North moved from Berlin to Middletown in 1813 , and built a factory at a cost of about $\$ 100$,000, where he employed seventy men and produced about thirty pistols a day. The interchangeable system was well begun in both of these factories by 1815 .

The Springfield armory had been started during the Revolution, mainly for making cannon. In 1792 Congress authorized the President to establish two arsenals for small arms. These were located at Springfield in the North, and Harper's Ferry in the South. In 1811 Captain Hall was granted a patent for a gun which was adopted as the government standard in 1819 and the Government undertook to manufacture them at one of its own armories. Captain Hall was placed in charge of 
the work and the plant at Harper's Ferry was equipped for interchangeable manufacture. ${ }^{14}$ Later many of these rifles were made by private contractors, such as Colonel North. By 1828 in one of Colonel North's contracts we find the principle of interchangeability extended still further. It is guaranteed that the component parts should be interchangeable, not only in the lot contracted for, but that they may be exchanged in a similar manner with the rifles made or making at the national armories. ${ }^{15}$

In 1836 Samuel Colt invented his revolver, and the first lot contracted for by the Government was made at the Whitney works in 1847. Mr. Colt determined about 1850 to establish his own factory, moved to Hartford, and in 1854-1855 built the present Colt's Armory, in which the principles of interchangeable manufacture were adopted in a most advanced form. Hand work was practically eliminated and automatic and semiautomatic machinery substituted. A type of manufacturing miller, built for this work by George S. Lincoln \& Company, is still known as the Lincoln miller. E. K. Root, superintendent under Colt, had a profound influence in the development of manufacturing at this time. He put the art of die forging on its present basis. At first he used a type of hammer in which four impressions were arranged in four different sets of dies. The hammers were lifted, first by a set of dogs, later by a centrai screw, and the operator walked around the machine, using the impressions successively. A few years later the present form of board drop was developed. Two of George S. Lincoln \& Company's men were Francis A. Pratt, superintendent, and Amos Whitney, contractor, who later founded the firm of Pratt \& Whitney.

14 "Memoir of Simeon North," pp. 168-169.

15 Ibid., p. 160. 
In 1857 Smith \& Wesson began manufacturing revolvers at Springfield along similar lines. Mr. Smith had worked in the old Whitney shops. Another firm of great influence was that of Robbins \& Lawrence, later the Windsor Machine Company, in Windsor, Vt. Frederick W. Howe built there a number of machines for profile milling, rifling, barrel drilling, and is said to have designed the first "universal" miller in 1852. ${ }^{16}$ The Ames Manufacturing Company in Chicopee, which had been founded in 1829, was also engaged in this work. By 1850 the interchangeable system began to extend its influence abroad. Robbins \& Lawrence had an exhibit of interchangeable guns in the exposition at London in 1851, which attracted much attention. In 1853 a British Commission came to this country and visited the government and private armories, the Ames Manufacturing Company and Robbins \& Lawrence. During the visit of this Commission at Springfield, Major Ripley, superintendent of the armory, ordered ten guns, which had been manufactured in ten successive years, from 1843 to 1853 , to be stripped, and the parts to be reassembled at random.

As a result of this visit 20,000 interchangeable Enfield rifles were ordered by the English Government, and in 1855, 157 machines for the manufacture of guns were sent to England. These machines comprised seventy. four millers, twenty-three drilling machines, five tapping machines, and seven edging machines. The remainder were special machines for threading, rifling, turning, boring, and so on. ${ }^{17}$ In this list of machines scarcely a single lathe is found and no mention is made

16 Not to be confused with the Bromn \& Sharpe universal milling machine, which was invented by Joseph $R$. Brown in 1871 .

17 Fitch: "Report on Manufactures of Interchangeable Mechanism," U. S. Census, 1880. Volume on "Manufactures." 


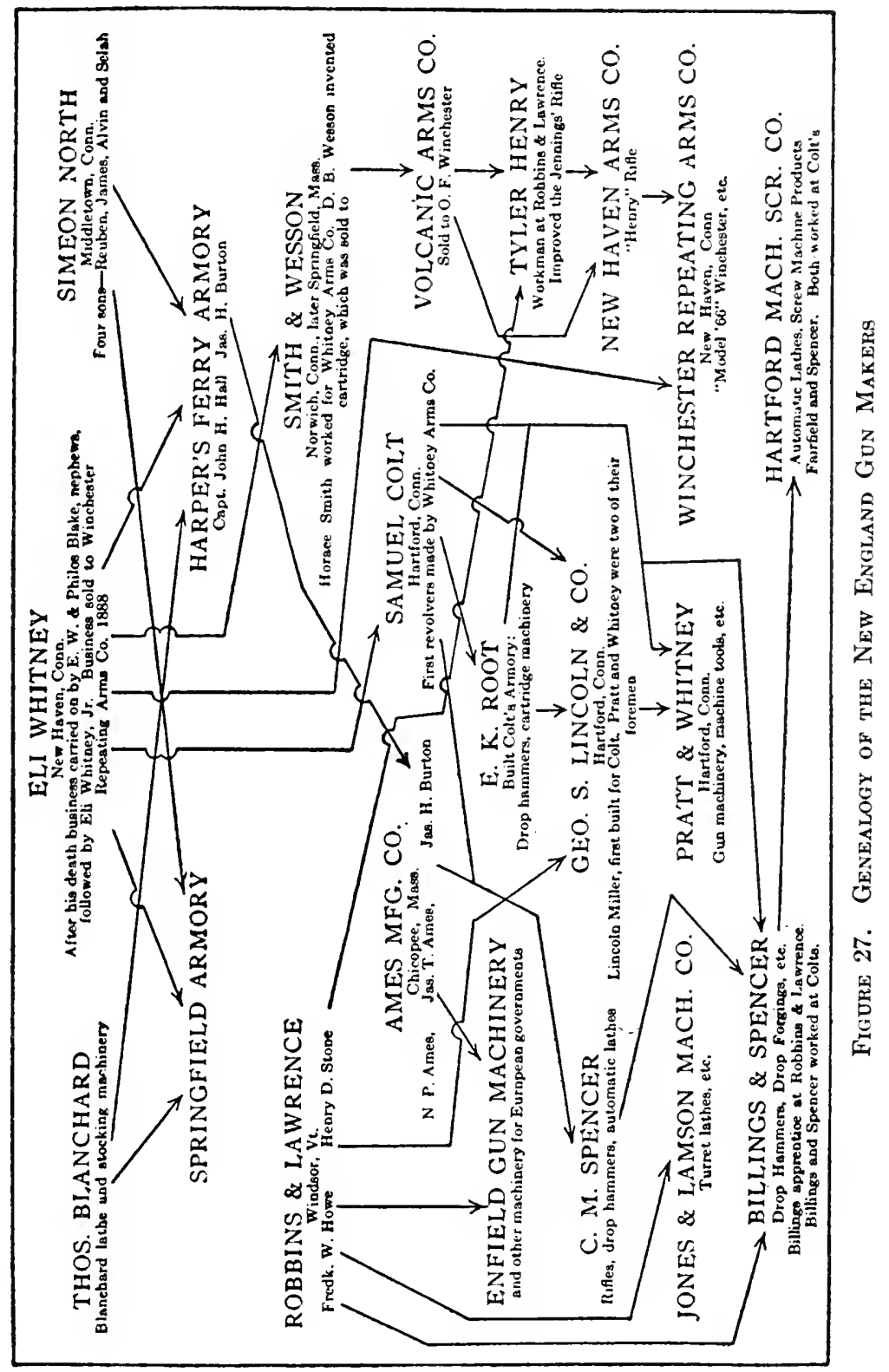


of any turret machines. Ten or fifteen years later there would have been a large number. James $H$. Burton, who had been at the Harper's Ferry armory and was at the time with the Ames Manufacturing Company, went over to England to install the new system and operate the new plant. The Ames Manufacturing Company alone is said to have exported four to five hundred stocking machines of the Blanchard type on these early foreign orders. Within the next fifteen or twenty years nearly every government in Europe was supplied with American gun-making machinery, all planned to operate on the interchangeable system, which was known everywhere as "the American system."

Nasmyth was concerned in the introduction of this machinery into England. His mention of it in his autobiography throws light on how the interchangeable system was looked upon by the English engineers:

In 1853 I was appointed a member of the Small Arms Committee for the purpose of remodeling and, in fact, re-establishing, the Small Arms Factory at Enfield. The wonderful success of the needle gun in the war between Prussia and Denmark in 1848 occasioned some alarm amongst our military authorities as to the state of affairs at home. The Duke of Wellington to the last proclaimed the sufficiency of "Brown Bess" as a weapon of offense and defense; but matters could no longer be deferred. The United States Government, though possessing only a very small standing army, had established at Springfield a small arms factory, where, by the use of machine tools specially designed to execute with the most unerring precision all the details of muskets and rifles, they were enabled to dispense with mere manual dexterity, and to produce arms to any amount. It was finally determined to improve the musketry and rifle systems of the English army. The Government resolved to introduce the American system, ${ }^{18}$ by which arms might be pro-

18 Italics are ours. 
duced much more perfectly, and at a great diminution of cost. It was under such circumstances that the Small Arms Committee was appointed.

Colonel Colt had brought to England some striking examples of the admirable tools used at Springfield ${ }^{19}$ and he established a manufactory at Pimlico for the production of his well-known revolvers. The committee resolved to make a personal visit to the United States Factory at Springfield. My own business engagements at home prevented my accompanying the members who were selected; but as my friend John Anderson (now Sir John) acted as their guide, the committee had in him the most able and effective helper. He directed their attention to the most important and available details of that admirable establishment. The United States Government acted most liberally in allowing the committee to obtain every information on the subject; and the heads of the various departments, who were intelligent and zealous, rendered them every attention and civility.

The members of the mission returned home enthusiastically delighted with the results of their inquiry. The committee immediately proceeded with the entire remodeling of the Small Arms Factory at Enfield. The workshops were equipped with a complete series of special machine tools, chiefly obtained from the Springfield factory. ${ }^{20}$ The United States Government also permitted several of their best and most experienced workmen and superintendents to take service under the English Government. $^{21}$

In using the term "interchangeable" it must be remembered that the meaning attached to this word grew during these years. The interchangeability of 1813 would not have been considered satisfactory in 1855, much less so today. When Hall completed his first hundred rifles

19 Hartford?

20 This must be a mistake. The machinery seems to have been supplied chiefly by Robbins \& Lawrence and the Ames Mfg. Co. Mr. Burton of the latter company installed it.

21 Autobiography of James Nasmyth, pp. 362-363. 
at Harper's Ferry in 1824, it is said that "the joint of the breech block was so fitted that a sheet of paper would slide loosely in the joint, but two sheets would stick." This system of gauging will have a familiar sound to the older mechanics who grew up before the days of the micrometer. When Colonel North was given his first contract for the rifles and furnished two models to work from, these models were so unlike that he asked to have one set aside and that he be allowed to gauge his work from the other.

Of the various tools associated with interchangeable manufacture, drilling jigs were in use very early, probably from the start. The filing $j i g$ is said to have been invented by Selah North, the son of Colonel North, but it was used by Whitney almost as early. Both Whitney and Colonel North were using plain milling by 1820. A light sort of milling machine is shown in the French Encyclopedia of 1772 , already referred to, but the first successful one was built by Mr. Whitney some time prior to 1818. This machine, still in existence and now in the possession of the Sheffield Scientific School of Yale University, is shown again in Fig. 28. ${ }^{22}$ In 1817 to 1822 we find the introduction of forging in hand dies, barrel turning by special machinery, and the Blanchard lathe for gun-stocks. Receiving ganges are said to have been used at Middletown in 1829, and were regularly in use at Springfield by 1840. Automatic machinery for the woodworking was first invented by Blanchard in 1818 for the Springfield armory. The accuracy of these machines, shown in Fig. 29, outran that of the metal work of the time. To accommodate the variations still present in the metal parts Blanchard devised a machine which used the actual lock plates as formers and cut

22 For a detailed account of this machine and its history see American Machinist, Vol. XXXVI, p. 1037. 


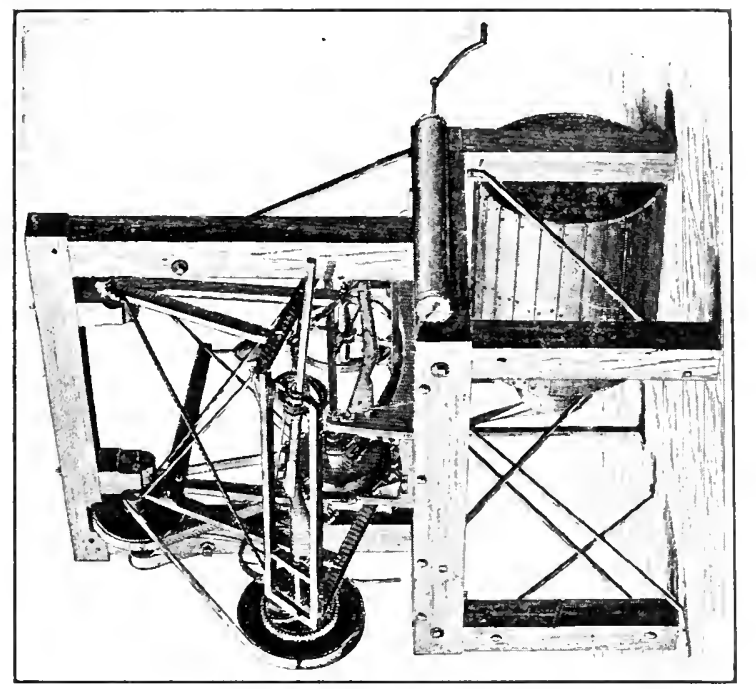

0
0
0

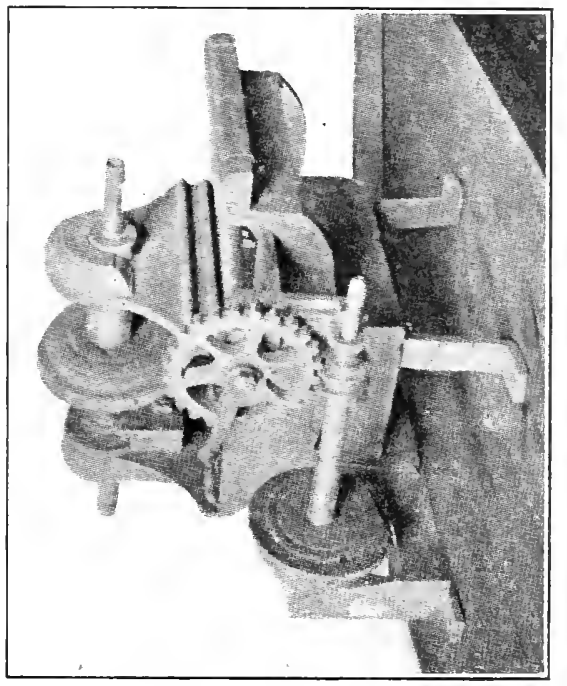

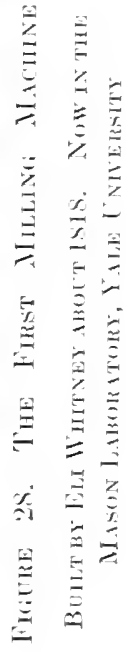



the stocks to match, and such machines were used at Springfield until 1840. By that time the work on the metal parts could be made as accurately as the stocks, and this method was no longer necessary. A modern degree of accuracy in. shaping of the metal portions was not possible until the miller came into general use for irregular shapes, which was some time in the forties. By 1842, for the new musket to be manufactured at Springfield, there was a complete set of model jigs, taps and gauges. The profiling machine was developed by F. W. Howe, R. S. Lawrence, and E. K. Root, from 1848 to 1852 . A drop hammer with dies was used by Hall of Harper's Ferry in 1827, the head of which was raised by a moving chain and freed by a trip at the desired height. Later Peck invented his lifter, using a strap. The Root drop hammers we have already mentioned. The board drop is largely the work of Spencer.

Probably no machine has had so great an influence on interchangeable manufacture as the automatic turret lathe. The turret lathe, "the first radical improvement on Maudslay's slide-rest," was built commercially by Robbins \& Lawrence in 1854 , and is said to have grown out of a revolving-head bolt cutter which Henry D. Stone saw at Hartford. The turret idea was not originated by Stone. Root and Howe had used it a number of years before, and it had been utilized by several others. All of these turrets except Howe's seem to have had a horizontal axis instead of the vertical one which became general. Later improvements by C. M. Spencer and a long line of brilliant mechanics have increased the accuracy of the turret lathe and made it more nearly automatic than any other type of general machine tool. Today it is, with the milling machine, the main reliance for interchangeable work.

In sketching the development of interchangeable 


\section{ENGLISH AND AMERICAN TOOL BUILDERS}

methods in American shops, we have confined our attention to gun makers chiefly. They were by no means the only ones to have a part in this development, but they were its originators, they determined its methods, and developed most of the machines typical of the process. About 1830 Chauncey Jerome began the manufacture of brass clocks. Terry, Thomas and other Connecticut mechanics had been manufacturing wooden clocks, which gave way to metal clocks as the advantage of interchangeable manufacture became recognized. In 1848 A. L. Dennison founded the American Watch Company at Waltham. The interchangeable system has nowhere reached a higher development than in the work of this company and of the other great watch factories. In 1846 Elias Howe was granted his patent on sewing machines, and within four or five years their manufacture sprang up on a large scale. Both of these industries, watch and clock manufacture and the manufacture of sewing machines, utilized a system which was already well established. Since that time it has been applied to a wide variety of articles. 


\section{CHAPTER XII \\ WHITNEY AND NORTH}

In the last chapter we considered the rise of the interchangeable system of manufacture and saw that it started in the shops of Eli Whitney, at New Haven, and of Simeon North, at Middletown. The lives of these men are of much interest, particularly that of Whitney. His struggle in defense of his patent rights on the cotton gin is instructive for all who see a high road to fortune in the patenting of a valuable invention.

Measured by its economic effect, the cotton gin is one of the greatest of inventions. As an industrial factor its success was immediate and far-reaching. It developed the agricultural resources of nearly half the United States, made possible its gigantic cotton crop, vastly increased the wealth of this country and, to a scarcely less extent, that of England; and yet toward the end of his life, Mr. Whitney said that he had hardly more than "come out even on it"; and this in spite of the fact that his patent was sustained and was apparently one of the most valuable ever granted.

A patent for an invention which meets a widespread and pressing need, and for which there is a tremendous demand, is difficult to defend. Watt's rights in the steam engine were established only after a long and bitter fight, and he would have failed and died a disappointed man had it not been for the indomitable courage and business skill of his partner, Matthew Boulton. Whitney was a far better business man than Watt, but his 
partner was not in any way the equal of Boulton. If he had been, the story of the cotton gin might have been different.

Whitney saw the futility of depending solely on patent rights and wisely turned his splendid talents to manufacturing; where, without patent protection of any kind, by methods then new, but which have since spread throughout the world, he built up a fortune. Someone has said that the besetting sin of mechanics is invention. This may, or may not, be true, but it is worth pondering whether superior methods and business judgment are not still the best industrial protection.

Eli Whitney, whose portrait is shown in Fig. 30, was born in Westborough, Mass., in 1765. He came from that best school of mechanics, the New England hill farm. Most of the early American mechanics, like him, came from the country and had the same training of hard work with simple implements, and learned to turn their hand to nearly everything, and to work with few and rough tools. From his boyhood he showed mechanical talent. When he was fifteen, with his father's consent, he began making nails with the aid of such rudimentary tools as he could contrive. This was during the Revolntionary War, when nails were in great demand and bronght a high price. By hard work he built up a profitable little business which he carried on for two winters in addition to the ordinary work of the farm during the summer. The business grew beyond his capacity to care for alone, so he set out on horseback to a neighboring town in quest of a fellow laborer. Not finding one as easily as he had anticipated, he rode from town to town with the persistence which was a strong trait in his character, until forty miles from home he found such a workman as he desired. During this jonrney he called at every workshop on his way and absorbed all the infor- 
mation he could respecting the mechanical arts. When the nail business ceased to be profitable after the war, he turned his attention to knife blades and to the making of the long pins for bonnets then in fashion. He showed so much skill that he-nearly monopolized the latter business.

When nineteen years old, Whitney determined to obtain a liberal education, but he was not able to gain his father's consent until he was twenty-three. Then, in 1788 , with money made partly in his little manufacturing business and partly from teaching school, he entered Yale College. He completed his college education with but little expense to his father who paid a few of the last of his college bills, for which the son gave his note and which he paid soon after graduation. His work at college was creditable, rather than brilliant; he left a marked impression behind him for good judgment, sound reasoning and steady, intelligent work. ${ }^{1}$

There were few school facilities in the South at that time and many of the wealthy planters had their children educated by private tutors. In the fall of 1792, the year in which he graduated, Whitney was engaged as a private tutor in a family in Georgia. On his way there he met Mrs. Greene, the widow of General Nathaniel Greene, who was returning to Savannah after spending the summer in the North. When Whitney reached Georgia he found that, despite his engagement, another had been given his place and he was stranded, practically penniless, a thousand miles from home and not knowing which way to turn. Mrs. Greene kindly invited him to make her house his home. He did so, and began to study law

1 The best sources of information on Whitney are: Olmstead: "Memoir of Eli Whitney, Esqr." New Haven, 1846. Blake: "History of Hamden, Conn." New Haven, 1888. Blake: "Sketch of the Life of Eli Whitney," “'New Haven Colony Historical Society Papers,', Vol. V, 1894. 
under her hospitable roof. Here he met Phineas Miller, a native of Connecticut and also a graduate of Yale College, who had himself come south as a tutor in the Greene family and after General Greene's death had become manager of his estate. He was a man of cultivated mind, of eager, hopeful temperament and later he married Mrs. Greene.

Shortly after Whitney's coming, a large party of gentlemen from Augusta and the upper country, consisting principally of officers who had served under the General in the Revolutionary army, were visiting Mrs. Greene. In the course of the conversation the deplorable state of agriculture was discussed, and great regret expressed that there was no means of separating green seed cotton from its seed, since all the lands which were unsuitable for the cultivation of rice and long staple cotton, would yield large crops of green seed cotton. The black or long staple cotton had already been introduced successfully in the Sea Islands, but it could not be grown inland. It was vain to think of raising green seed or upland cotton for the market unless some machine could be devised which would facilitate the process of cleaning. Separating one pound of the staple from the seed was a day's work for one woman. During this conversation Mrs. Greene told them that Whitney could invent their machine, saying, "He can make anything." This incident turned Whitney's attention to the subject. Encouraged by Miller he dropped his law studies, went to Savamnah, obtained a small parcel of raw cotton, and set himself at work on the problem. With such resources as the plantation afforded he made tools suited to his purpose, drew his own wire and by the close of the winter had so far developed the machine as to leave no doubt of its success. The first model he made (made, it is said, in about two weeks) is still in existence 
in the possession of his grandson, the present Eli Whitney. The three essential elements of his gin, the rotary wheel with forward pointing wires or teeth, the slotted bar, and the revolving brushes for cleaning the teeth, remain practically unchanged today.

At that time the market was glutted with such products as Georgia produced, trade was languishing, and there was little employment for the negroes or support for the white inhabitants. Mrs. Greene indiscreetly showed the first machine to visitors and the news soon leaked out that a means had been devised for separating more cotton in one day, with the labor of a single man, than could have been done in the usual manner in the space of many months. An invention so important to the agricultural interest could not long remain a secret. The knowledge spread throughout the state and so great was the excitement that multitudes from all quarters came to see the machine. It was not deemed safe to gratify their curiosity until patent rights were secured, but so determined were they that the building was broken into by night and the machine carried off. In this way the public became possessed of the invention, and before Whitney could secure his patent a number of machines were in successful operation. They deviated only slightly from the original and gave Whitney much trouble later in establishing his rights to the invention.

In the spring of 1793, Miller and Whitney formed a partnership under the name of Miller \& Whitney, for developing the business, and Whitney returned to Connecticut to perfect the machine, obtain a patent, and manufacture and ship to Georgia machines to meet the demand. At the start they made a fatal error of policy in deciding to buy the seed themselves, gin it and sell the product. Protected by their patent, they planned to maintain a monopoly of this business. Later they were 
willing to manufacture and sell the machines for general use or to sell the rights. If they had done this at the start much of the opposition which they incurred might have been obviated. Whitney, at least, was a clearsighted business man and if he had realized the magnitude of the result of his invention he would probably not have chosen this course.

There is not another instance in the history of invention of the letting loose of such tremendous industrial forces so suddenly. The inventions of Arkwright, Watt, Fulton and Stephenson have affected society quite as profoundly as did that of the cotton gin, some of them more so, but in none of these cases were the results so immediate. In 1784 only eight years before Whitney's invention, eight bales of cotton from the United States which were landed at Liverpool were seized on the ground that they could not have been produced in the United States. ${ }^{2}$ In 1791 the total production of cotton in the world was estimated at 490,000,000 pounds, of which the United States produced 2,000,000 pounds, or only $1 / 245$, of which 189,316 pounds were exported. In 1792 they exported 138,328 pounds, an actual decrease of 51,000 pounds from the previous year. In 1793 , the year after the gin was invented, there was an exportation of 487,000 pounds; in 1794 of $1,601,000$ pounds; in 1795 of $6,276,000$ pounds. By 1800 the total production had risen to $35,000,000$ pounds, of which $17,790,000$ pounds were exported. In 1845 the total estimated output of the world was $1,169,600,000$ pounds, of which the United States produced nearly seveneighths. ${ }^{3}$ At the present time the output of the United

2 Olmstead: “Memoir of Eli Whitney, Esqr," p. 63. Also, Encyclopedia Britannica, Elerenth Edition, Vol. VII, p. 264.

3 Olmstead: "Memoir." Also Merchant's Magazine, Vol. VI, Article on "History of the American Cotton Trade," by James H. Lanman. 
States is about $15,000,000$ bales, or $7,000,000,000$ pounds. Less than 1 per cent of this is "Sea Island" or long staple cotton. All the rest is upland or green seed cotton, cleaned on the Whitney type of gin, and made commercially available by his method of cleaning.

The intensity of the demand for the use of this machine made it practically impossible to defend a patent right upon it. The patent laws of the country, as has been stated, were crude at that time, and the infringement suits were tried before juries composed of the very men who were interested in breaking the patent.

Nearly all of the great inventions have been developments to which a number of inventors have contributed, as in the case of the steam engine, the locomotive, and the steamboat; but the fundamental invention of the cotton gin was due to Whitney and to Whitney alone. And yet in a letter written to Robert Fulton, at a later date, he says :

My invention was new and distinct from every other: it stood alone. It was not interwoven with anything before known; and it can seldom happen that an invention or improvement is so strongly marked, and can be so clearly and specifically identified; and I have always believed, that I should have had no difficulty in causing my rights to be respected, if it had been less valuable, and been used only by a small portion of the community. But the use of this machine being immensely profitable to almost every planter in the cotton districts, all were inter. ested in trespassing upon the patent-right, and each kept the other in countenance. Demagogs made themselves popular by misrepresentation and unfounded clamors, both against the right and against the law made for its protection. Hence there arose associations and combinations to oppose both. At one time, but few men in Georgia dared to come into court and testify to the most simple facts within their knowledge, relative to the use of the machine. In one instance, I had great difficulty in proving 
that the machine had been used in Georgia, although, at the same moment, there were three separate sets of this machinery in motion, within fifty yards of the building in which the court sat, and all so near that the rattling of the wheels was distinctly heard on the steps of the court-house. ${ }^{4}$

It should in justice be said that at first there was no widespread disposition on the part of the Georgia planters to avail themselves of the invention unlawfully, but later nearly all, deluded by the general attitude, joined in the attack upon the inventor's rights.

The unfortunate policy adopted by Miller \& Whitney worked to their disadvantage in two ways. First, they could not themselves produce machines fast enough to gin the rapidly increasing crops; and second, their policy of buying the seed and ginning it themselves meant financing the entire crop and called for a vastly greater capital than they had at their command. Infringing machines sprang up on every side, their most formidable rival being the saw gin of Hodgin Holmes, in which circular saws were used instead of a drum with inserted wires as in Whitney's original gin. The idea of such teeth had occurred to Whitney, as he afterward proved; but not until 1807 did he completely establish his right over this machine.

Perplexities and discouragements dogged their steps from the start. In 1795 the shop which they had built in New Haven, together with all machines and papers, was consumed by fire. In the diary of President Stiles of Yale College is an entry: "March 12 (1795). Yesterday morning Mr. Whitney's workshop consumed by fire. Loss 3000 Dol. about 10 finished machines for seeding cotton \& 5 or 6 unfinished, \& all the tools which no man can make but Mr. Whitney, the inventor, \& which he has been 2 years in making." They found great diff4 Olmstead, p. 58. (Italies are ours.) 


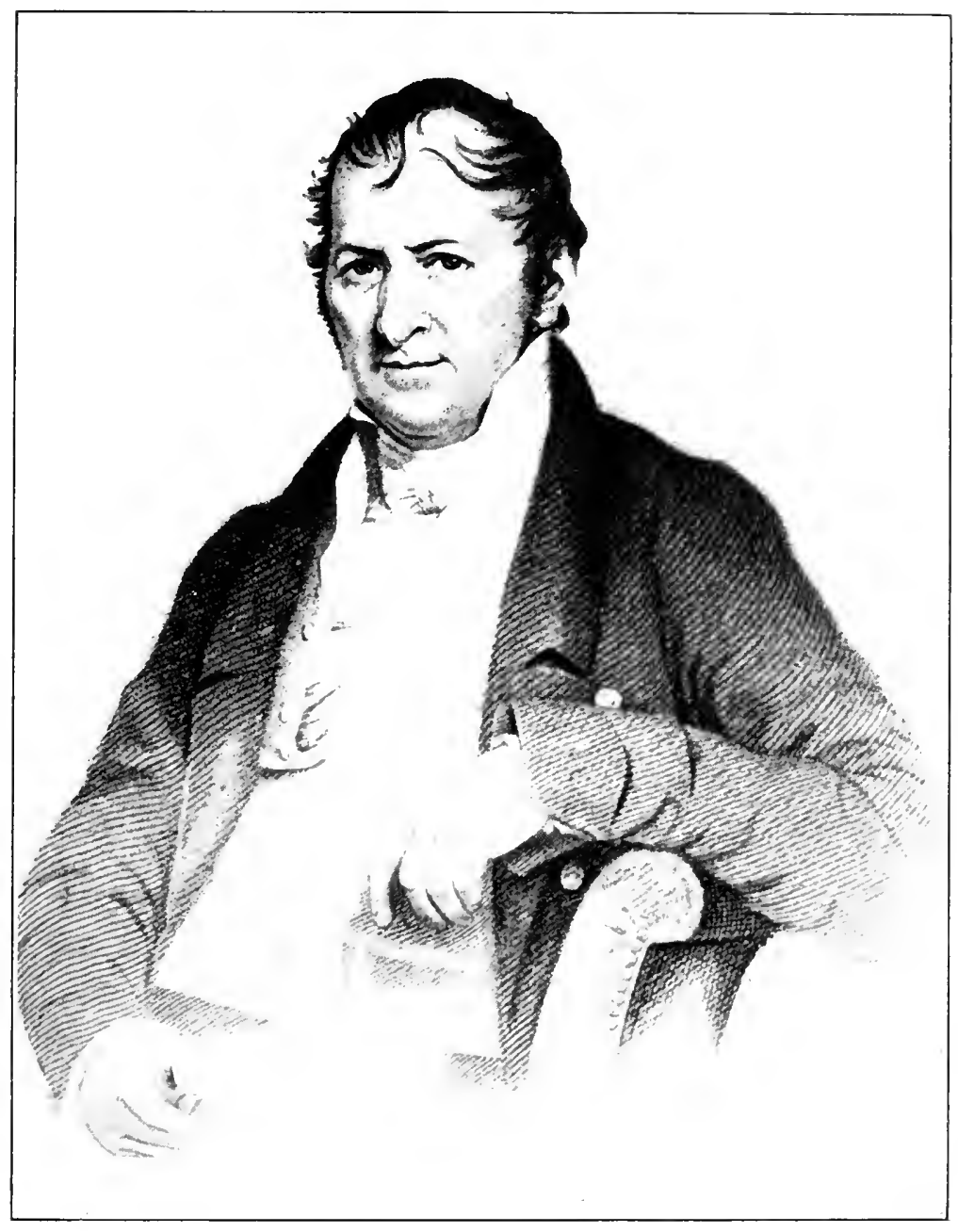

Figure 30. Eli Mhitatey 

culty in raising money, even at rates from 12 to 25 per cent. With these misfortunes upon them, word was received from England that the manufacturers condemned the cotton cleaned by their machines on the ground that the staple was injured. They had thirty gins at work in eight different places in Georgia and many of these were brought to a standstill. It was nearly two years before this prejudice could be overcome. By that time, however, encroachments on their patent right had become so extensive as almost to annihilate its value. The first infringement suit was tried in 1797 and went against them. An appeal was denied on technicalities. ${ }^{5}$ At a second trial, in 1798, a great number of witnesses had been collected from various parts of the country, some of them from one hundred miles away, when the judge failed to appear, and, of course, no court was held. ${ }^{6}$ Mr. Miller writes in 1799 that "the prospect of making anything by ginning in this State, is at an end. Surreptitious gins are being erected in every part of the country; and the jurymen at Augusta have come to an understanding among themselves, that they will never give a verdict in our favor, let the merits of the case be as they may." "The firm would now gladly have relinquished their plan of doing the ginning themselves and confined their operations to the sale of patent rights; but few people would buy a patent right which could be used with impunity without purchase.

In 1801 South Carolina voted the purchase of the patent rights on the cotton gin for that state for $\$ 50,000$, $\$ 20,000$ to be paid in hand and the remainder in three annual payments of $\$ 10,000$ each. A year later Whitney sold the right for North Carolina. The legislature laid

\footnotetext{
5 Ibid., p. 26.

6 Ibid., p. 27.

7 Ibid, p. 27.
} 
a tax on every saw, to be continued for five years. After deducting the expenses of collection, the proceeds were to be passed over to the patentee. Negotiations were also entered into with the state of Tennessee. The prospects of the firm were, therefore, growing more favorable, when the legislature of South Carolina suddenly annulled the contract, refused payment due, and sued for the refunding of what had already been paid. Doubts were raised as to the validity of the patent; the patentees were charged with nonfulfillment of a part of their contract relating to the submission of models; it was charged that somebody in Switzerland had conceived of the idea beforehand; and that Whitney had been antedated in the use of saws instead of wire teeth by Holmes. This action was the result of the political agitation against the patent, which was strong throughout the cottongrowing states. Tennessee followed the example of South Carolina, and the same attempt was made in North Carolina, but the legislative committee to whom it was referred reported in Whitney's favor, declaring that such action was a breach of contract and of good faith. In $1803 \mathrm{Mr}$. Miller, who had represented the firm in the South, died disappointed and broken by the struggle.

In the following year South Carolina rescinded its action and carried out its contract, so that from North and South Carolina Whitney received a considerable sum. In all he received about $\$ 90,000 ; \$ 50,000$ from North Carolina; at least $\$ 30,000$ from South Carolina and about $\$ 10,000$ from Tennessee. A large portion of this amount was, however, balanced by the cost of the endless litigation in Georgia. More than sixty suits had been instituted in the latter state before the first decision was obtained on the merits of the claims.

This decision was rendered in the United States Court 
in December, 1807, by Judge Johnson. Whitney, as the survivor of the firm of Miller \& Whitney, was suing a man named Arthur Fort for violation of the patent right and for a perpetual injunction restraining him from use of the gin. Judge Johnson's decision is so clear a statement of the situation, and so splendid an example of justice in the face of popular agitation that we give it nearly in full:

Defendant admits most of the facts in the bill set forth, but contends that the complainants are not entitled to the benefits of the act of Congress on this subject, because :

1st. The invention is not original.

2d. It is not useful.

$3 \mathrm{~d}$. That the machine which he uses is materially different from their inventions, in the application of an improvement, the invention of another person. . . .

There are circumstances in the knowledge of all mankind, which prove the originality of this invention more satisfactorily to the mind, than the direct testimony of a host of witnesses. The cotton plant furnished elothing to mankind before the age of Herodotus. The green seed is a species much more productive than the blaek, and by nature adapted to a much greater variety of climate. But by reason of the strong adherence of the fiber to the seed without the aid of some more powerful machine for separating it, than any formerly known among us, the cultivation of it would never have been made an object. The Machine of which Mr. Whitney claims the invention, so facilitates the preparation of this species for use, that the eultivation of it has suddenly become an object of infinitely greater national importance than that of the other species ever can be. Is it then to be imagined that if this machine had been before discovered, the use of it would ever have been lost, or could have been confined to any tract or country left unexplored by commercial enterprise? But it is unnecessary to remark further upon this subject. A number of years have elapsed since Mr. Whitney took out his patent, and no one has produced or pre- 
tended to prove the existence of a machine of similar construction or use.

2d. With regard to the utility of this discovery, the Court would deem it a waste of time to dwell long upon this topic. Is there a man who hears us, who has not experienced its utility? The whole interior of the Southern States was languishing, and its inhabitants emigrating for want of some object to engage their attention and employ their industry, when the invention of this machine at once opened views to them, which set the whole country in active motion. From childhood to age it has presented to us a lucrative employment. Individuals who were depressed with poverty and sunk in idleness, have suddenly risen to wealth and respectability. Our debts have been paid off. Our capitals have increased, and our lands trebled themselves in value. We cannot express the weight of the obligation which the country owes to this invention. The extent of it cannot now be seen. Some faint presentiment may be formed from the reflection that cotton is rapidly supplanting wool, flax, silk, and even furs in manufactures, and may one day profitably supply the use of specie in our East India trade. Our sister states, also, participate in the benefits of this invention; for, besides affording the raw material for their manufactures, the bulkiness and quantity of the article afford a valuable employment for their shipping.

3d. The third and last ground taken by the defendant, appears to be that on which he mostly relies. In the specification, the teeth made use of are of strong wire inserted into the cylinder. A Mr. Holmes has cut teeth in plates of iron, and passed them over the cylinder. This is certainly a meritorious improvement in the mechanical process of constructing this machine. But at last, what does it amount to except a more convenient method of making the same thing? Every characteristic of Mr. Whitney's machine is preserved. The cylinder, the iron tooth, the rotary motion of the tooth, the breast work and brush, and all the merit that this discovery can assume, is that of a more expeditious mode of attaching the tooth to the cylinder. After being attached, in operation and effect they 
are entirely the same. Mr. Whitney may not be at liberty to use Mr. Holmes' iron plate, but certainly Mr. Holmes' improvement does not destroy Mr. Whitney's patent right. Let the decree for a perpetual injunction be entered. ${ }^{8}$

This decision was confirmed by a series of subsequent ones, and from that time onward there was no serious questioning of the patent right.

In $1812 \mathrm{Mr}$. Whitney made application to Congress for the renewal of his patent. In his memorial he points out that his patent had nearly expired before it was sustained; that his invention had been a source of wealth to thousands of citizens of the United States; that the expense to which he had gone in defense of the patent had left him little or no return on the invention; that the men who had grown rich by the use of his machine had combined to prevent the patentee from deriving reward from his invention; that in the state where he had first introduced the machines he had received nothing; that from no state had he received all told an amount equal to $1 / 2$ cent per pound on the cotton cleaned by his machine in one year; that the whole amount received by him for his invention had not been equal to the labor saved in one hour by the cotton gins then in use in the United States; that the invention had already trebled the value of land throughout a great extent of territory; that the degree to which the cultivation of cotton would still be augmented was incalculable; and that the species of cotton grown had from time immemorial never been known as an article of commerce until his method of cleaning it had been invented. He closed with an argument for the policy of providing adequate reward for the encouragement of invention. ${ }^{\circ}$ Notwithstanding these argu-

8 Ibid., p. 39.

9 Itid., pp. 55.57. 
ments and a favorable committee report, the application was rejected. With the exception of a few liberal-minded men, nearly all the members from the cotton-growing states opposed the application strongly.

Whitney combined in a singular degree high inventive capacity with clear judgment and steady determination. By 1798 he saw that his hopes for any large return from the cotton gin were uncertain. He turned to the manufacture of firearms and by steady, sure steps built up another business and died a well-to-do man. In this second enterprise he developed the interchangeable system of manufacture and thereby influenced modern society almost as greatly as he had in the invention of the cotton gin, although this is little realized by the general public.

In the chapter on "The Rise of Interchangeable Manufacture" we traced Whitney's work as a gun manufacturer from 1798, when he first applied for his contract for ten thousand muskets. His undertaking of this contract required courage and self-confidence. Although he was not a trained gun maker, he proposed "from the start" to manufacture guns by a new method, which was ridiculed by those familiar. with the manufacture of firearms at that time. He had to build a plant, design and equip it with new and untried types of tools; and to educate workmen to his methods. Furthermore, he did this work, involving $\$ 134,000$, under bond for satisfactory performance. The high estimation in which Whitney was held by those who knew him is evidenced by the fact that, although he was already embarrassed and embarking on an entirely new kind of enterprise, ten of the foremost men of New Haven signed his bond for the faitlful performance of his contract.

A contemporary, intimately acquainted with his work, has outlinea his method of manufacture in words which 
describe the interchangeable system, as it exists today, so accurately that we give it in full:

The several parts of the muskets were, under this system, carried along through the various processes of manufacture, in lots of some hundreds or thousands of each. In their various stages of progress, they were made to undergo successive operations by machinery, which not only vastly abridged the labor, but at the same time so fixed and determined their form and dimensions, as to make comparatively little skill necessary in the manual operations. Such were the construction and arrangement of this machinery, that it could be worked by persons of little or no experience, and yet it performed the work with so much precision, that when, in the later stages of the process, the several parts of the musket eame to be put together, they were as readily adapted to each other, as if each had been made for its respective fellow. . . . It will be readily seen that under such an arrangement any person of ordinary capacity would soon aequire sufficient dexterity to perform a branch of the work. Indeed, so easy did Mr. Whitney find it to instruct new and inexperienced workmen, that he uniformly preferred to do so, rather than to attempt to combat the prejudices of those who had learned the business under a different system. ${ }^{10}$

It took him a much longer time to fulfill the contract than he had anticipated; two years elapsed before his plant was ready. Only 500 guns were delivered the first year instead of 4000 , and the entire contract required eight years instead of two from the time when he began actual manufacture. In spite of this delay he kept the confidence of the government officials, who were very liberal in their treatment of him; so much had been advanced to him to help him develop his machinery that when the contract was completed only $\$ 2450$ out of the total of $\$ 134,000$ remained to be paid. The work was highly satisfactory, and in 1812 he was awarded another 10 Ibid., pp. 53-54. 
contract for 15,000 muskets from the United States Government and one for a similar number from the State of New York. What is known of his methods and machinery is given in the chapter referred to, which shows also how they spread to other armories throughout the country.

The business which Mr. Whitney started was carried on for ninety years. After his death in 1825 the armory was managed for ten years by Eli Whitney Blake, later inventor of the Blake stone crusher, and Philos Blake, his nephews. From 1835 to 1842 it was managed by ex-Governor Edwards, a trustee of Mr. Whitney's estate. His son, Eli Whitney, Jr., then became of age and assumed the management, and that same year obtained a contract for making the "Harper's Ferry" rifle,-the first percussion lock rifle, all guns before that date having had flint locks.

Eli Whitney, Jr., continued to develop the art of gun making. He introduced improvements in barrel drilling and was the first to use steel for gun barrels. In 1847, during the Mexican War, Jefferson Davis, then a colonel in a Mississippi regiment, wrote to the Ordnance Department at Washington, that it was his opinion that the steel-barreled muskets from the Whitney armory were "the best rifles which had ever been issued to any regiment in the world.' The Whitney Arms Company supplied the Government with more than 30,000 rifles of this model. The company continued in existence until 1888, when the plant was sold to the Winchester Repeating Arms Company. It was operated by them for a number of years in the manufacture of 22-calibre rifles. This work was subsequently removed to their main works and the plant was sold to the Acme Wire Company, and later to the Sentinel Gas Appliance Company, its present owner. Some of the original buildings are 
still standing. It may be of interest to note that at the time the works were first built, a row of substantial stone houses was built by Whitney for his workmen, which are said to have been the first workmen's houses erected by an employer in the United States.

In person Mr. Whitney was tall and dignified. $\mathrm{He}$ had a cultivated mind and a manner at once refined, frank and agreeable. He was familiar with the best society of his day and was a friend of every president of the United States from George Washington to John Quincy Adams. He had a commanding influence among all who knew him. Seldom has a great inventor been more sane, for his powers of invention were under perfect control and never ran wild. Unlike those who devise many things but complete few, he left nothing half executed. Robert Fulton said that Arkwright, Watt and Whitney were the three of his contemporaries who had done the most for mankind. ${ }^{11}$ Lord Macaulay is quoted as saying, "What Peter the Great did to make Russia dominant, Eli Whitney's invention of the cotton gin has more than equaled in its relation to the progress and power of the United States." 12 He contributed immeasureably to the agriculture and the manufacturing methods of the whole world and few mechanics have had a greater influence.

Simeon North was born at Berlin, Conn., the same year as Whitney, and like him, started life as a farmer. In 1795 he began making scythes in an old mill adjoining his farm. Just when he began making pistols is not clear. It is said that he made some for private sale as early as the time of the Revolution, and it is probable that he had begun their manufacture in a small way prior to receiving his first government contract. $\mathrm{He}$

11 Blake: “History of Hamden, Conn.,' p. 303.

12 Devans: “Our First Century,', p. 153. 
may have learned the rudiments of the trade from Elias Beckley, who had a gun shop about a mile from North's birthplace. ${ }^{13}$

In March of 1799 , about a year after Whitney received his first contract for muskets, North received his first contract for horse-pistols, 500, which were to be delivered in one year. This was followed by others for 1500 in $1800 ; 2000$ in $1802 ; 2000$ in $1808 ; 1000$ in 1810 , and other's not known. By 1813 he had made at least 10,000 and was employing forty or fifty men. In none of these contracts was there any mention made of interchangeability, but some time during these years North began to use interchangeable methods. The correspondence quoted in the previous chapter and the quotations already given show that Whitney was working on the same basis from the start. It is a great pity that Colonel North's papers were destroyed after his death, as they might have thrown some light on the question as to how and when he began to use interchangeable methods. It is impossible now to say how much Whitney and North influenced each other if they did at all. In 1812 the Secretary of War visited North's shop at Berlin, Conn., and urged him to increase his plant. On receiving the contract of $\mathbf{1 8 1 3}$, North purchased land in Middletown, Conn., and built a dam and a three-story brick armory, $86 \times 36$ feet, on the best lines known at that time, involving in all an expenditure of $\$ 100,000$. The old factory was run in conjunction with the new one until 1843, when it was closed.

North began making barrels of steel in 1848, only a year or two after Eli Whitney, Jr., and contributed many improvements in the design of the pistols and guns which he built. The Remington Arms Company, the Savage Fire Arms Company, the Maynard Rifle Com-

13 The fullest account of Simeon North is given in the "Memoir of Simeon North,' ' by S. N. D. North and R. H. North. Concord, N. H., 1913. 
pany and the Massachusetts Arms Company, all trace back in some way to him, and, like Whitney, he deeply influenced the practice of the United States Government in its armories at Springfield and Harper's Ferry.

Colonel North's first contract with the Government was made in 1799 ; his last was finished in 1853 , a year after his death, covering in all about 50,000 pistols and 33,000 rifles. He worked under sixteen administrations, representing all parties, and in all the fifty-three years he never received a reproof or a criticism of his work.

He had an old-fashioned sense of honor. In 1826 he was called on to pay a note for $\$ 68,000$ which he har indorsed. Although advised that he could not be held legally, he said that his name was there and he would stand by it. He placed a mortgage on his property, and it was twenty-two years before he had made good the loss, which, principal and interest, amounted to over $\$ 100,000$. But for this endorsement he would have died, for that time, a wealthy man. Colonel North was a country-bred man, strong, quiet and almost painfully modest. He lacked Whitney's education and influence, but like him he represented the best which American mechanical and business life has produced. 


\section{CHAPTER XIII}

\section{THE COLT ARMORY}

The city of Hartford has been more closely identified with the later development of interchangeable manufacture than almost any other city. The gun makers have been so vital an element in its industrial life that, before leaving them, we will trace their influence.

The grist and saw mills, always the pioneers, had made their appearance in the seventeenth century. With recurring attempts at silk manufacture, most of the meager industrial life was directed toward some branch of textiles up to and even after 1800.

In 1747 Col. Joseph Pitkin started a prosperous forge for making bar iron and a mill for iron slitting. It was killed by the Act of Parliament of 1750 , already referred to, but the Pitkin family balanced the account by using the buildings during the Revolution to make powder for the Continental army. Later the buildings were put to their original use. The Pitkins were industrial leaders for many years in textiles, and in the manufacture of silverware, clocks, watehes, and heating apparatus. Henry and James F. Pitkin made the old "American lever" watehes in 1834, and many of the early workmen who went to Waltham were trained by them.

The assessors' returns for 1846 to the Secretary of State gave for Hartford only three "machine factories" with a total capital of $\$ 25,000$, an annual output of $\$ 35,000$, and forty-five men employed. There were two 


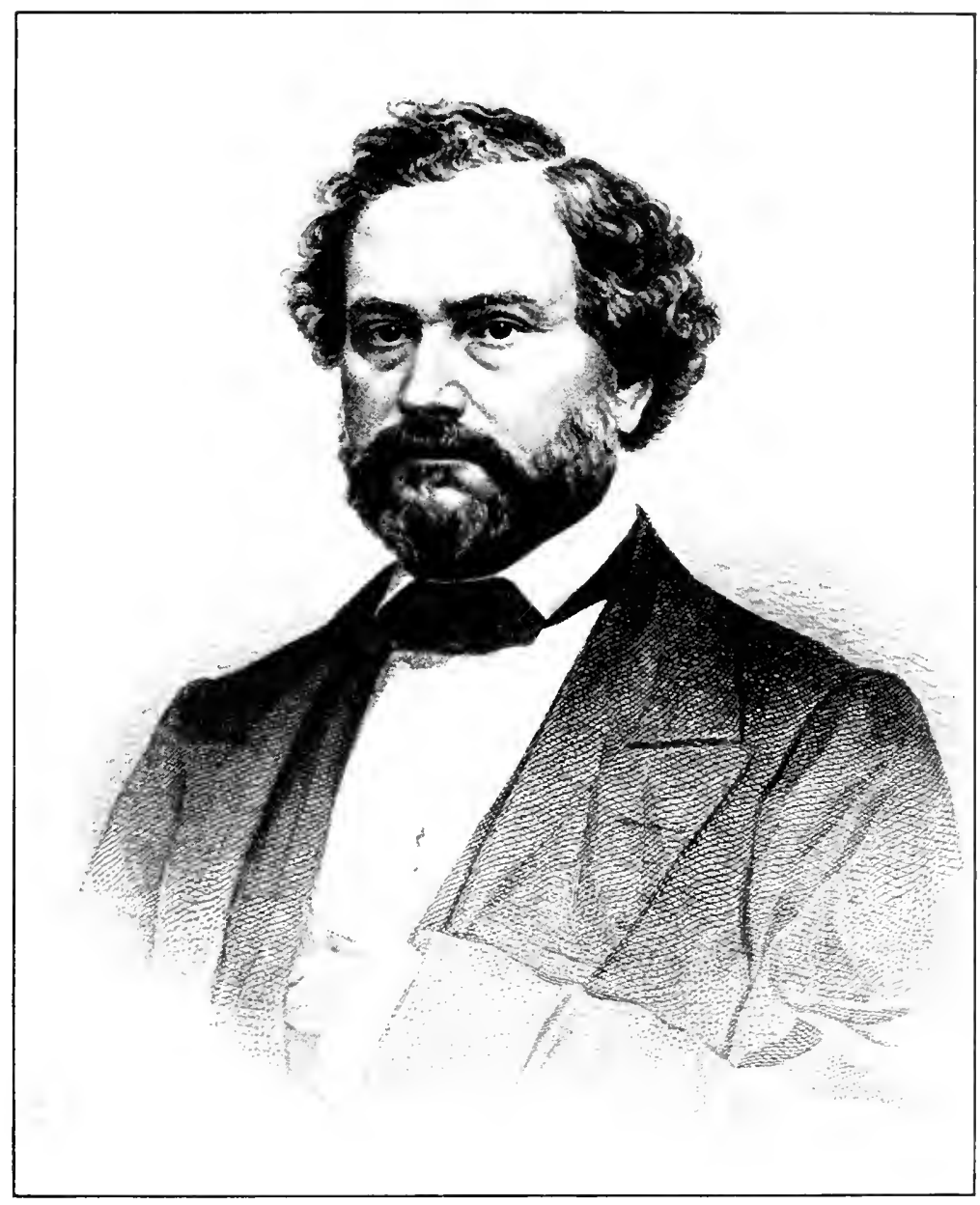

Figure 31. SAmuel Colt 
boiler shops, a screw factory, a plow factory, a pin factory, two brass and four iron foundries, and one poor gun maker who did a business of $\$ 625$ a year. Taken together, these enterprises averaged only about $\$ 15,000$ in capital, $\$ 20,000$ in annual output and fifteen employees each. This is hardly more than would be expected in any town of its size, and certainly does not mark the city as a manufacturing center. Book publishing employed over twice, and clothing shops more than four times, as many men as all the machine shops together.

In 1821 Alpheus and Truman Hanks purchased a small foundry and began the business which later became Woodruff \& Beach. This firm had a long and successful career in building heavy machinery, engines and boilers, and was among the earliest makers of iron plows. In 1871 it became H. B. Beach \& Son, boiler makers, and the firm is still running, H. L. Beach being now (1914) the only survivor of the old works.

In 1834 Levi Lincoln started the Phœnix Iron Works. Under various names (George S. Lincoln \& Company, Charles L. Lincoln \& Company, The Lincoln Company, The Taylor \& Fenn Company) the business has been maintained by his descendants to this day. Levi Lincoln invented a number of machines, among them the first successful hook-and-eye machine for Henry North of New Britain, which became very valuable and helped to lay the foundation of the prosperity of that town. George S. Lincoln \& Company built machine tools, architectural iron work and vaults. Their name is permanently associated with the "Lincoln" miller, which was first built in 1855 in their shop for the new Colt Armory, from the design of F. A. Pratt. It was an adaptation and improvement of a Robbins \& Lawrence miller which had been brought to Hartford a year or two before. Few machines have changed so little or have been used so 
widely. It has been said that more than 150,000 of them have been built in this country and abroad. Even in Europe, the type is definitely known by this name.

The building of the Colt Armory in 1853 to 1854 marks a definite era in Hartford's history and the beginning of manufacturing there on a large scale. Samuel Colt had an adventurous life, and died in the midst of his success while less than fifty years old. Born in Hartford in 1814, he had a rather stormy career as a schoolboy and shipped before the mast to Calcutta before he was sixteen. After his return from this voyage, he worked for some months in his father's dye works at Ware, Mass., where he got a smattering of chemistry. At eighteen he started out again, this time as a lecturer under the name of "Dr. Coult," giving demonstrations of nitrous-oxide, or laughing gas, which was little known to the public at that time. Dr. Coult's "lectures" were frankly popular, with a view more to laughter than the imparting of knowledge, but he was clever and a good advertiser. It is said that he gave laughing gas to more men, women and children than any other lecturer since chemistry was first known. For three years he drifted over the country from Quebec to New Orleans, getting into all kinds of experiences, from administering gas for cholera when impressed into service on account of his assumed title, to fleeing the stage from big blacksmiths who took laughing gas too seriously and actively.

He made the first crude model of his revolver on his voyage to Calcutta and used the means derived from his "lectures" for developing the invention. In 1835 he went to England and took out his first patent there and on his return in 1836 he took out his first American patent. These covered a firearm with a rotating cylinder containing several chambers, to be discharged through a single barrel. The same year, 1836, he organized the 
Patent Fire Arms Company at Paterson, N. J., and tried to get the revolver adopted by the United States Government. In 1837 an army board reported "that from its complicated character, its liability to accident, and other reasons, this arm was entirely unsuited to the general purposes of the service."

Colt's first market was secured on the Texas frontier. His earliest revolvers are known as the Walker and Texas models, and the hold which he acquired with frontiersmen at that time has never been lost. The Seminole War in Florida gave Colt an opportunity to demonstrate the value of the revolver. In 1840 two government boards gave it a qualified approbation and two small orders followed, one for one hundred and the other for sixty weapons. The pistols, however, were expensive, the sales small, and in 1842 the Paterson company failed and ceased business.

In the next few years the tide turned. The superiority of the revolvers outstanding was creating a great demand. With the breaking out of the Mexican War in 1846 came two orders for 1000 pistols each, and from that time onward Colt's career was one of rapid and brilliant success.

As his Paterson plant had closed, Colt had the first of the large government orders made at the Whitney Armory in New Haven, where he followed minutely every detail of their manufacture. The following year, 1848, Colt moved to Hartford and for a few years rented a small building near the center of the city. With rapidly increasing business, larger quarters soon became necessary.

In 1853 he began his new armory, shown in Fig. 32. South of the city on the river front, lay an extensive flat, overflowed at high water and consequently nearly valueless. He purchased a large tract of this, built a 
protective dike 30 feet high and $13 / 4$ miles long, and drained it. His armory built on this site marks an epoch not only in the history of Hartford, but in American manufacturing.

After the failure of his first venture at Paterson, Colt had seen the advantage of interchangeable manufacture at the Whitney shop, and determined to carry it even further in his new plant. So thoroughly was this done that the methods crystallized there, and many of the tools installed have undergone little change to this day. Machine work almost wholly superseded hand work. Modern machines were developed, and interchangeability and standards of accuracy given an entirely new meaning.

The building was in the form of an " $\mathrm{H}$," 500 feet long and $31 / 2$ stories high. It contained over 1400 machines, the greater part of which were designed and built on the premises. The tools and fixtures cost about as much as the machines themselves, a proportion unheard of before. In 1861 the plant was doubled. Three years later the first building was burned to the ground, but was immediately rebuilt. This plant was the largest private armory in the world and far-and-away the best then existing for economical and accurate production of a high-grade output. Many rivals have sprung up in the past sixty years, but the Colt Armory is still one of the leading gun factories of the world.

Colonel Colt was a remarkable man, masterful, daring and brilliant. He started the larger industrial development of his city, and affected manufacturing methods more than any other man of his generation.

One of the elements of his success was his ability to gather and hold about him men of the highest order. Among these was Elisha K. Root, one of the ablest mechanics New England has ever produced. Root was a 


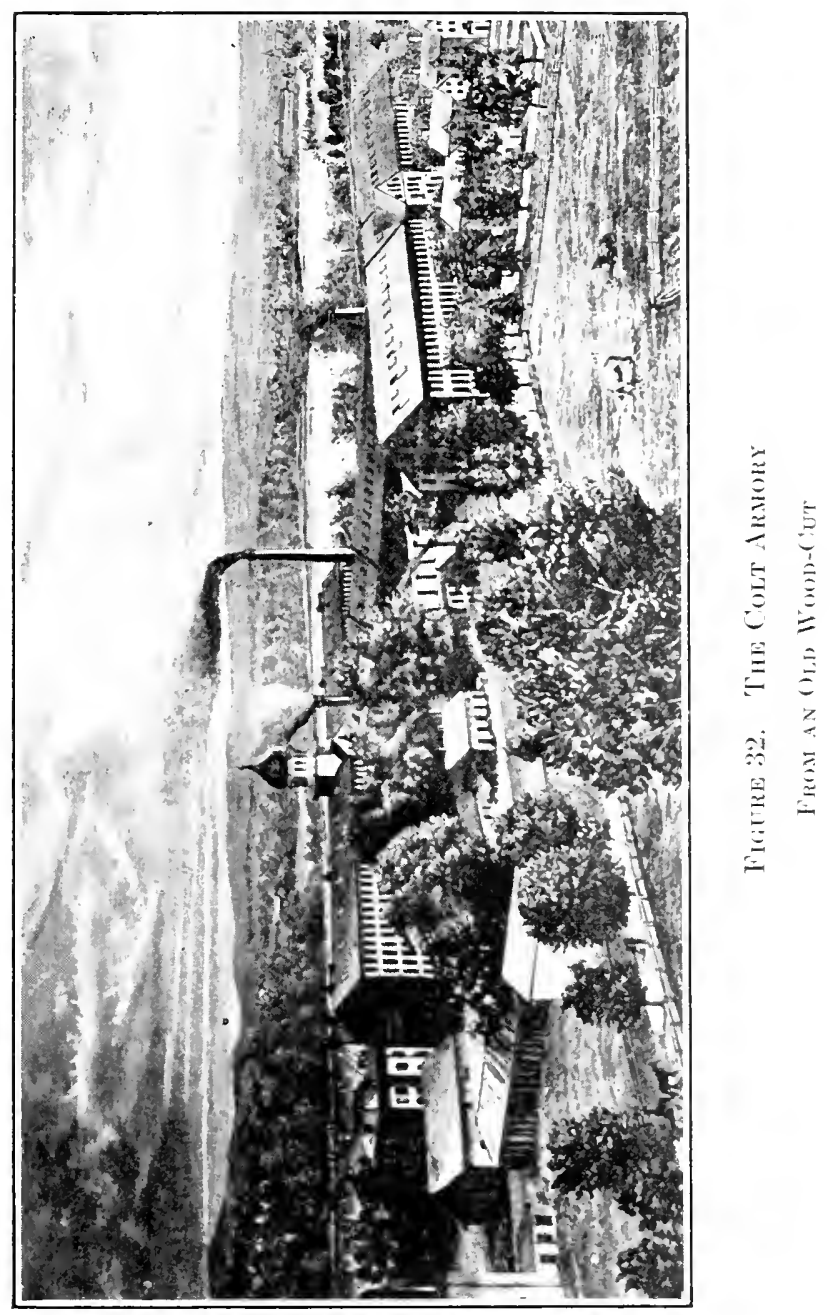


Massachusetts farmer's boy, a few years older than Colt. He served an apprenticeship, worked at Ware and at Chicopee Falls, and came to the Collins Company, axe makers, at Collinsville, Conn., in 1832. He began work there as a lathe hand in the repair shop, but very soon became foreman and virtual superintendent. His inventions and methods converted a primitive shop into a modern factory and gave the Collins Company control, for a long time, of the American market, and opened up a large export trade. In 1845 he was made superintendent, and that same year was offered three important positions elsewhere, one of them that of master armorer at Springfield.

In 1849 Colt offered him the position of superintendent at a large salary. It was characteristic of Colt that, although he was just starting and still in small rented quarters; he outbid three others to get the best superintendent in New England. Root moved to Hartford, designed and built the new armory and installed its machinery. Many of the machines devised by him at that time are still running, holding their own in accuracy and economy of production with those of today. Almost every process used in the plant felt his influence. He invented the best form of drop hammer then in use, machines for boring, rifling, making cartridges, stock turning, splining, etc., and worked out the whole system of jigs, fixtures, tools and gauges. The credit for the revolver belongs to Colt; for the way they were made, mainly to Root. Fig. 33, a chucking lathe, and Fig. 34, a splining machine, are two of Mr. Root's machines which are still at work. When Colonel Colt died, Mr. Root became president of the company and continued until his death in 1865, receiving, it is said, the highest salary paid in the state of Connecticut. He was a mechanic and inventor of high order, a wise executive, and the 
success of the two companies he served was in a large measure due to him. He was quiet, thoughtful and modest. His influence went into flesh and blood as well as iron and steel, for under him have worked F. A. Pratt and Amos Whitney, Charles E. Billings and C. M. Spencer, George A. Fairfield, of the Hartford Machine Screw Company, William Mason and a host of others whom we cannot mention here. Like a parent, a superintendent may be judged, in some measure, by the children he rears, and few superintendents can show such a family.

Within a few years after the building of the Colt Armory, manufacturing at Hartford had taken a definite character. From that day to this it has centered almost wholly on high-grade products, such as guns, sewing machines, typewriters, bicycles, automobiles and machine tools. Naturally, during the past generation, the skilled mechanics of the city have attracted many new and important industries, only indirectly connected with the armory, which we cannot consider here.

In 1848 Christian Sharps invented his breech-loading rifle, and in 1851 a company was formed at Hartford to manufacture it. Richard S. Lawrence came from Windsor, Vt., as its master armorer, and is said to have brought with him the first miller used in the city. They did a large business for some years, but later moved to Bridgeport, and the plant was sold to the Weed Sewing Machine Company. C. E. Billings and George A. Fairfield, both "Colt men," were superintendents of this plant. When the Columbia bicycles were introduced, the Weed Sewing Machine Company made them for the Pope Manufacturing Company of Boston. Later this company bought the plant, and it became one of the greatest bicycle factories in the world. Of late years it has been used for the manufacture of automobiles. 


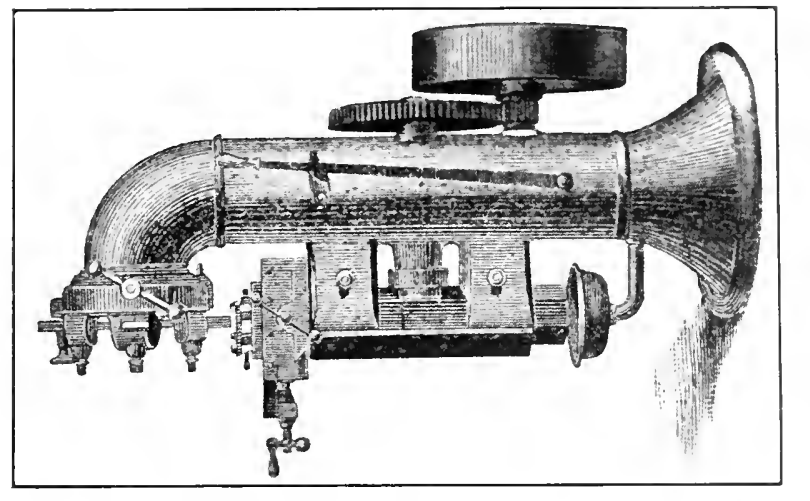

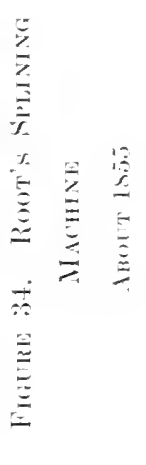

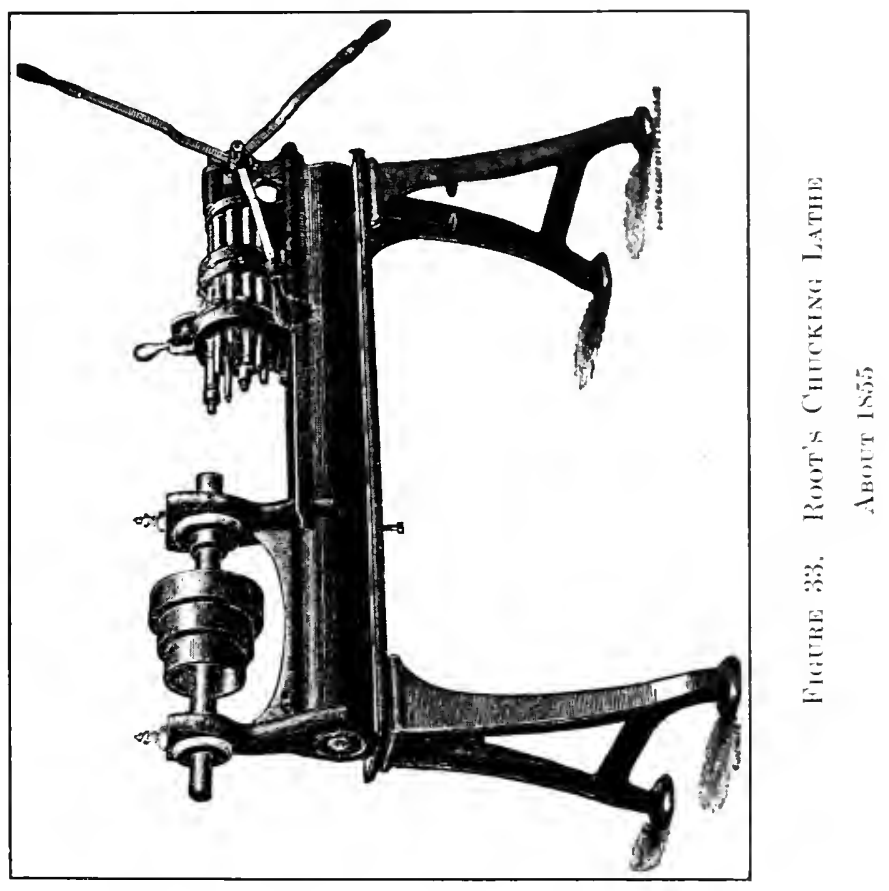


Two great industries sprang up in the neighborhood of Hartford in the early days and had a vigorous life quite independent of it. We have noted that Levi Lincoln contributed to the establishment of the hardware industry at New Britain. . Although New Britain is but a few miles from Hartford, its manufactures have moved in a distinctly different direction. In fact, by 1820 it had taken its character as a hardware manufacturing center. North \& Shipman had begun making sleigh-bells, hooks and plated goods, and Lee was making buttons and saddlery hardware. In 1839 Henry E. Russell and Cornelius B. Erwin became active partners in Stanley, Russell \& Company, the beginning of the Russell \& Erwin Manufacturing Company. The Stanley Works and Landers, Frary \& Clark had their beginnings in 1842; P. \& F. Corbin in 1848, and the Stanley Rule \& Level Company in 1854. About the same time, Elnathan Peck, after a partnership with George Dewey and Henry Walter, sold out to J. B. Sargent, who later moved to New Haven. Mr. Peck also moved to New Haven and started what is now Peck Brothers. It is a remarkable case of the localization of a great industry. These companies, all large and important, started within fifteen years in one small village of only a few thousand inhabitants.

The other industry which started near Hartford but has developed separately is the manufacture of clocks. Early in the nineteenth century Eli Terry, first at Windsor, just north of Hartford, and later at what is now Thomaston, Conn., began using machinery in making wooden clocks, and by 1840 he had reduced the price for a movement from $\$ 50$ to $\$ 5$. About 1840 Chauncey Jerome, an apprentice of Terry's, introduced the one-day brass clock which could be made for less than fifty cents. In 1842 he shipped his first consignment to England. 
They were promptly confiscated at their invoice prices by the customs authorities for under-valuation. This was perfectly agreeable to Jerome, as it furnished him with a spot-cash buyer at full price, with no selling expenses. He therefore sent another and larger shipment, which shared the same fate. When a third still larger one arrived, the authorities withdrew from the clock business and let it in. The exports soon spread everywhere, and today Connecticut manufactures threefifths of the clocks produced in the United States.

Nearly all the great clock companies of Connecticut, like the New Haven, Seth Thomas and Waterbury companies, trace back directly or indirectly to Jerome and Terry. 


\section{CHAPTER XIV}

\section{THE COLT WORKMEN-PRATT \& WHITNEY}

At least two of the superintendents of the Colt Armory should be mentioned-Prof. Charles B. Richards and William Mason.

Mr. Richards was not primarily a tool builder, but his contributions to mechanical engineering are too great to pass without notice. About 1860 he helped Charles T. Porter develop the design of the first highspeed steam engine, and in order to study the action of this engine he invented the Richards steam engine indicator. Indicators, more or less crude, had been in use from the time of Watt, but the Richards indicator was the first one accurate enough and delicate enough to meet the demands of modern engine practice; and its influence has been far-reaching. After a few years in New York as a consulting engineer, he was for many years in the Colt Armory as engineering superintendent under Mr. Root, and later was superintendent of the Southwark Foundry \& Machine Company in Philadelphia. In 1884 he became Professor of Mechanical Engineering at the Sheffield Scientific School of Yale University, where he remained for twenty-five years as the head of the mechanical engineering department.

William Mason was another of those who helped make the Colt Armory what it was. He was a modest, kindly man, little known outside of his immediate associates, but of singular fertility in invention and almost unerring mechanical judgment. He learned his trade with 
the Remington Arms Company at Ilion, N. Y., and after a long association with them he was for sixteen years superintendent of the Colt Armory. In 1885 he became master mechanic of the Winchester Repeating Arms Company of New Haven, and held that position until his death in 1913. He had granted to him more than 125 patents, most of them in connection with arms and ammunition and tools for their manufacture, but they included many appliances for looms and weaving, steam pumps, and bridge work, and he assisted with the development of the Knowles steam pump and Knowles looms.

Asa Cook, a brother-in-law of F. A. Pratt, was for years a foreman and contractor at Colt's. He was afterwards a designer and manufacturer of machinery for making wood screws, bolt machinery and many other types of tools. George A. Fairfield, another Colt foreman, became superintendent of the Weed Sewing Machine factory and later president of the Hartford Machine Screw Company; another workman, A. F. Cushman, of the Cushman Chuck Company, for many years manufactured lathe chucks. In fact, there is hardly a shop in Hartford which dates from the seventies and eighties which does not trace back in some way to the Colt Armory. Its influence is by no means confined to Hartford, for such men as Bullard and Gleason carried its standards and methods to other cities.

Four of the Colt workmen formed two partnerships of wide influence: Charles E. Billings and Christopher M. Spencer, who organized the Billings \& Spencer Company, and Francis A. Pratt and Amos Whitney, of the Pratt \& Whitney Company.

Charles E. Billings was a Vermonter, who served his apprenticeship in the old Robbins \& Lawrence shop at Windsor, Vt. When twenty-one, he came to Colt's, in 1856, as a die sinker and tool maker and became their 
expert on the drop forging process. In 1862 he went to E. Remington \& Sons, where he built up their forging plant, increasing its efficiency many times, saving $\$ 50$,000 , it is said, by one improvement in frame forging alone. At the end of the war he returned to Hartford as the superintendent of the Weed Sewing Machine Company, which had taken over the old Sharps Rifle Works, built by Robbins \& Lawrence. For a short time in 1868 Mr. Billings was at Amherst, Mass., associated with Spencer in the Roper Repeating Arms Company. The venture was not a success, and the next year, 1869, they came back to Hartford and formed the Billings \& Spencer Company. This company has probably done more than any other for the art of drop forging, not only in developing the modern board drop hammer itself, but in extending the accuracy and application of the process. Mr. Billings was president of the American Society of Mechanical Engineers in 1895.

Christopher M. Spencer was born at Manchester, Conn. He served his apprenticeship in the machine shops of the silk mills there from 1847 to 1849 , and remained for several years as a journeyman machinist with Cheney Brothers. In 1853 he went to Rochester, N. Y., to learn something of the other kinds of machinery, working in a tool building shop and a locomotive shop. After some years at the Colt Armory he went back to Cheney Brothers and soon obtained his first patent for an automatic silk-winding machine. This was adopted by the Willimantic Linen Company, with some modifications made by Hezekiah Conant, and was the machine which Pratt \& Whitney began manufacturing in their first rented room in Hartford.

Mr. Spencer has had a passion for firearms from boyhood. In 1860 he obtained a patent for the Spencer repeating rifle. The Civil War created a tremendous 
demand for it, and the Government ordered first 1000 , then 10,000, and before the war was over it had purchased about 200,000. In 1862, while the first contracts were pending, Spencer saw President Lincoln at Washington. He and Lincoln went down on the White House grounds with the new rifle, set up a board and shot at it. Lincoln enjoyed it like a schoolboy, and shot well, too. He tore his coat pocket in the process, but told Spencer not to worry over it, as he "never had anything of value in it to lose."

At the close of the war Spencer went to Amherst and was there first associated with C. E. Billings in the Roper Company, as we noted. A year later he joined in starting the Billings \& Spencer Company and coöperated with him in the development of the drop hammer.

A successful machine which Spencer invented for turning sewing machine spools suggested to Spencer the possibility of making metal screws automatically. The result was his invention of the automatic turret lathe. The importance of the blank cam cylinder, with its flat strips adjustable for various jobs, was wholly overlooked by his patent attorney, with the result that Spencer obtained no patent right on the most valuable feature in the whole machine.

The importance of this invention can hardly be overestimated. It ranks with Maudslay's slide-rest and the turret tool-holder, as it is an essential feature in all modern automatic lathes, both for bar-stock and chucking work.

Assured of the success of the machine, Spencer withdrew from active connection with the Billings \& Spencer Company in 1874, and in 1876, with George A. Fairfield, then superintendent of the Weed Sewing Machine Company, and others, formed the Hartford Machine Serew Company, one of the most successful enterprises in the 
city. Unfortunately, Mr. Spencer withdrew in 1882 to manufacture a new repeating shotgun and rifle which he had invented. The gun was a success mechanically, but the Spencer Arms Company, which had been formed in 1883 at Windsor, Conn., was a failure, and Mr. Spencer lost heavily. In his later years Mr. Spencer has returned to the field where he did his most brilliant work, automatic lathes. He represents the New England mechanic at his best, and his tireless and productive ingenuity has made a permanent impress on modern manufacturing methods.

Francis A. Pratt was born at Woodstock, Vt. When he was eight years old his family moved to Lowell. He was a mechanic from boyhood but he had the good fortune to be apprenticed as a machinist with Warren Aldrich, a good mechanic and a wise teacher. At twenty, Mr. Pratt went to Gloucester, N. J., where he was employed first as a journeyman, later as a contractor. In 1852 he came to the Colt shop, where he worked for two years. He then accepted the foremanship of the Phœnix Iron Works, which was run by Levi Lincoln and his two sons.

Amos Whitney was born in Maine and moved to Lawrence, Mass., where he served his apprenticeship with the Essex Machine Company which built cotton machinery, locomotives and machine tools. He came from a family of mechanies. His father was a locksmith and machinist, his grandfather was an expert blacksmith, his great-grandfather was a small manufacturer of agricultural tools, and he is of the same family as Eli Whitney of New Haven, and Baxter D. Whitney, the veteran tool builder of Winchendon. In 1850 both he and his father were working at Colt's factory at Hartford. In 1854 Amos Whitney joined Pratt in the Phœnix Iron Works, where they worked together for ten years, 
the former as a contractor, the latter as superintendent. Whitney was earning over eight dollars a day when he left Colt's and took up the new contract work which offered at the beginning only two dollars a day.

Many of the shops of that generation were "contract shops." The Colt Armory was run on that basis, at least in its manufacturing departments. Under this system the firm or company furnished all the materials, machinery, tools, shop room and supplies, while the workmen were employed by the contractor, their wages being paid by the firm but charged against the contractor's account. A better training for future manufacturers conld hardly be devised, and a surprising number of these old-time contractors have succeeded later in business for themselves.

In the summer of 1860 Pratt and Whitney rented a small room and, in addition to their regular employment, began doing work on their own account, i.e., manufacturing the small winder for the Willimantic Linen Company. Mr. Whitney's father-in-law acted as pattern maker, millwright, bookkeeper and general utility man. The following February they were burned out, but were running again a month later in other quarters. Here they continued to spread from room to room until all available space was outgrown. They succeeded from the very start, and at once became leaders and teachers of other mechanics, suggesters of new methods of work and of new means for its accomplishment. Both Pratt and Whitney were thoroughly familiar with gun manufacture, and the business was hardly started when the outbreak of the Civil War gave them more than they could do. In 1862 they took into partnership Monroe Stannard of New Britain, each of the three contributing $\$ 1200$. Mr. Stannard took charge of the shop, as Pratt and Whitney were still with the Phœnix Iron 

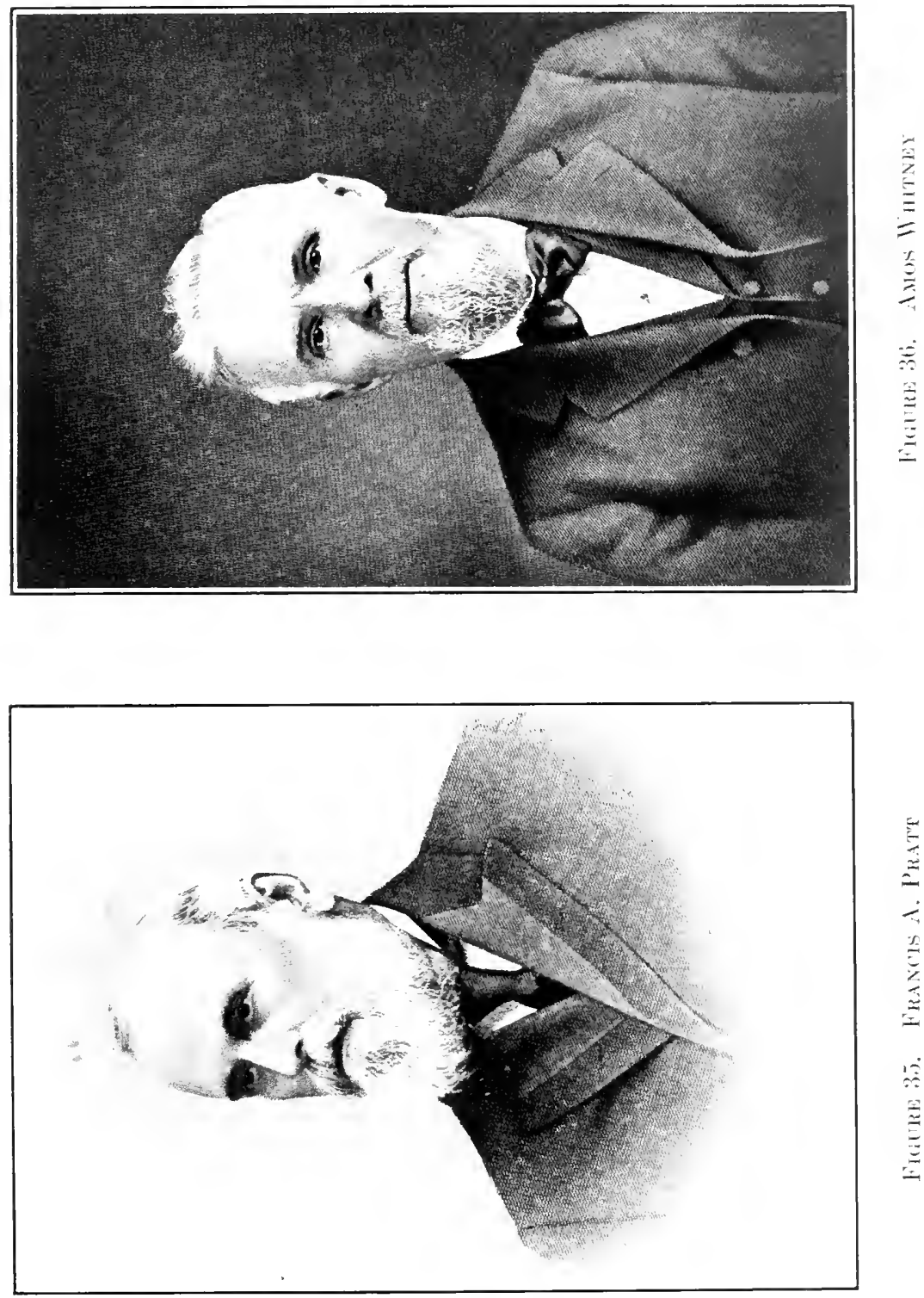

ב 
Works. Within two years the business had increased to such an extent that they gave up their positions at the Phœnix works and in 1865 erected the first building on their present site. From $\$ 3600$ in 1862 their net assets grew in four years to $\$ 75,000$, and during the three years following that they earned and put back into the business more than $\$ 100,000$. In 1869 the Pratt \& Whitney Company was formed with a capital of $\$ 350,000$, later increased to $\$ 500,000$. In 1893 it was reorganized with a capitalization of $\$ 3,000,000$. Since that time it has become a part of the Niles-Bement-Pond Company.

Beginning with the manufacture of machine tools and tools for making guns and sewing machines, they have extended their lines until their catalog fills hundreds of pages. From their wide experience in interchangeable manufacture, it was natural that they should take a prominent part in developing the machinery for the manufacture of bicycles and typewriters, when, later, these were introduced.

Soon after the Franco-Prussian War, an agent of the company visited Prussia and found the royal and private gun factories equipped with old and inferior machinery and the armories bare. Mr. Pratt was sent for, and returned to Hartford with orders from the German Government for $\$ 350,000$ worth of gun machinery. During the next few years Mr. Pratt made no less than ten trips to Europe, taking orders aggregating over $\$ 2,000,000$ worth of machinery. When the panic of 1873 prostrated the industries of the United States, Pratt \& Whitney had orders, mostly foreign, which kept them busy until 1875. Their equipment of the three royal armories of Spandau, Erfurt and Danzig resulted in an improvement in quality of output and a saving of 50 per cent in wages. Pratt \& Whitney's production of gun-making machinery alone has run into many millions 
of dollars, and there are few governments which have not at one time or another purchased from them.

Pratt \& Whitney from the start were leaders in establishing standards, particularly in screw threads. Their gauges for pipe threads have for years been the standard for the country. The troubles which arose from the lack of agreement of standard gauges and the growing demand for interchangeable bolts and nuts led to a demand on the company for a set of gauges upon which all could agree.

In undertaking this work Pratt \& Whitney examined their own standards of length with reference to government and other standards in this country and abroad. The results were conflicting and very unsatisfactory. By different measurements the same bar would be reported as above and as below the standard length, and the investigation produced no results which could be used for a working basis. At length Prof. William A. Rogers of Harvard University, and George M. Bond, backed by the Pratt \& Whitney Company, developed the Rogers-Bond comparator with which they determined the length of the standard foot. When they began, the length of the yard and its subdivisions varied with the number of yardsticks. Professor Rogers' work was based on line measurement rather than the end measurement which had held sway from the time of Whitworth and which is now generally recognized to be inferior for final reference work. Professor Rogers went back of all the secondary standards to the Imperial Yard in London and the standard meter in the Archives at Paris. $\mathrm{He}$ obtained reliable transfers of these, and with the coöperation of the United States Coast Survey, the most delicate and exhaustive comparisons were made of the standard bars prepared by him for the use of the company with the government standard yard designated 
"Bronze No. 11." Many thousands of dollars and three years of time went into this work.

The methods used and the results obtained were examined and reported upon by a committee of the American Society of Mechanical Engineers, and the conclusion given in their report is as follows:

The completion of the Rogers-Bond comparator marks a long stride in advance over any method hitherto in use for comparison and subdivision of line-measure standards, combining, as it does, all the approved methods of former observers with others original with the designers. Comparisons can thus be checked thoroughly by different systems, so that the final result of the series may be relied on as being much nearer absolute accuracy than any hitherto produced.

The calipering attachment to the comparator deserves special commendation, being simple in the extreme, and solving completely the problem of end measurements within the limit of accuracy attainable in line reading, by means of the microscope with the micrometer eye-piece. The standard to which the end measurements are referred is not touched, and each measurement is referred back to the same zero, so that error from end wear does not enter into the problem. This attachment is in advance of all hitherto known methods of comparing end measures, either with other end measures or with line standards, both as to rapidity of manipulation and accuracy of its readings, the strong point in its construction being that it refers all end measures to a carefully divided and investigated standard bar, which is not touched during its use, and cannot be in the slightest degree injured by this service, thus giving convincing assurance that the measures and gauges produced by its use will be accurate and interchangeable.

In the opinion of this committee, the degree of accuracy already attained is such that no future improvements can occasion changes sufficiently great to affect the practical usefulness of the magnitudes here determined, or the interchangeability of 
structures based upon them with those involving further refinement.

Prof. W. A. Rogers and Mr. George M. Bond are unquestionably entitled to great credit for the admirable manner in which they have solved the problem of exact and uniform measurement, while the enterprise of the Pratt \& Whitney Company in bringing the whole matter into practical shape, is deserving of the thanks of the engineering community. ${ }^{1}$

The standards so obtained became the basis of the gauges which Pratt \& Whitney have produced.

In 1888 the company received its first order for Hotchkiss revolving cannon, and for three- and six-pounders rapid-fire guns. They have made hundreds of these guns for the secondary batteries of war vessels. In 1895 they brought out a one-pounder invented by E. G. Parkhurst, an expert mechanic, who had entered their employment as assistant superintendent in 1869 and later took charge of their gun department.

For many years the Pratt \& Whitney tool-room lathes were the standard for the country. Later their leadership was materially affected by the Hendey Machine Company of Torrington, Conn., who built a high grade tool-room lathe having the change-gear box which has since been applied to nearly all types of machine tools. The change-gear box is one of the important contributions to tool building made in recent years. Among the

1 Those interested may find detailed descriptions of the methods used and of the Rogers-Bond comparator in the following references: George M. Bond: Paper on "Standard Measurements," Trans. A. S. M. E., Vol. II, p. 80. George M. Bond: Paper on "A Standard Gauge System," Trans. A. S. M. E., Vol. III, p. 122. Report of Committee on Standards and Ganges, Trans. A. S. M. E., Vol. IV, p. 21 (quoted above). W. A. Rogers: Paper, "On a Practical Solution of the Perfect Screw Problem,' 'Trans. A. S. M. E., Vol. V, p. 216. Two lectures delivered by George M. Bond before the Franklin Institute, Philadelphia, in 1884, on: 1 . "Standards of Length and their Subdivision." 2. "Standards of Lengtb as Applied to Gauge Dimensions.' 
later developments introduced by Pratt \& Whitney is the process of thread milling, and they have designed a full line of machines for this work.

The Pratt \& Whitney works, like the Colt Armory, has been a training school for successful tool builders. Worcester R. Warner and Ambrose Swasey were both foremen at Pratt \& Whitney's and left there to go west, first to Chicago and then to Cleveland. Some account of these two men will be given in a later chapter. Pratt $\&$ Whitney have had a marked influence on tool building in Cleveland, for, in addition to Warner and Swasey, E. C. Henn and Hakewessel of the National Acme Manufacturing Company who developed the multispindle automatic lathe, A. F. Foote of Foote, Burt \& Company, and George C. Bardons of Bardons \& Oliver, come from their shop. Johnston of Potter \& Johnston, Pawtucket, was chief draftsman at Pratt \& Whitney's; and J. N. Lapointe who later developed the broaching machine, Dudley Seymour of Chicago, Gleason of the Gleason Works in Rochester, E. P. Bullard of Bridgeport, and F. N. Gardner of Beloit, Wis., inventor of the Gardner grinder, were all workmen there.

Mr. Gleason was also a workman in the Colt Armory. He went to Rochester in 1865 and the works which he developed form the most important tool building interest in western New York. There have been "a good many itarts there in tool building and almost as many finishes." Mr. Gleason always said that but for the training and methods he had gained at Hartford he would have shared their fate. Like many others, his company began with a general line of machine tools but has come to specialize on one type of machine, bevelgear cutters, of which they build a most refined type.

E. P. Bullard, like Gleason, worked at both Colt's and Pratt \& Whitney's. Later he formed a partnership 
with J. H. Prest and William Parsons, manufacturing millwork and "all kinds of tools" in Hartford. In 1866 he organized the Norwalk Iron Works Company of Norwalk, but afterwards withdrew and continued the business in Hartford. For a number of years Mr. Bullard was in the South and Middle West, at Athens, Ga., at Cincinnati, where he organized the machine tool department of Post \& Company, and at Columbus, where he was superintendent of the Gill Car Works. In 1875 he established a machinery business in Beekman Street, New York, under the firm name of Allis, Bullard \& Company. Mr. Allis withdrew in 1877 and the Bullard Machine Company was organized. Recognizing a demand for a high grade lathe he went to Bridgeport, Conn., and engaged A. D. Laws to manufacture lathes of his design, agreeing to take his entire output. In the latter part of the same year Mr. Bullard took over the business and it became the Bridgeport Machine Tool Works. In 1883 he designed his first vertical boring and turning mill, a single head, belt feed machine of 37 inches capacity. This is believed to be the first small boring machine designed to do the accurate work previously performed on the face plate of a lathe. Up to that time boring machines were relied on only for large and rough work. In 1889 he transferred his New York connections to J. J. McCabe and gave his entire attention to manufacturing, the business being incorporated as the Bullard Machine Tool Company in 1894.

The building of boring mills gradually crowded out the lathes, and for twenty years the company has concentrated on the boring machine as a specialty. In their hands it has received a remarkable development. They introduced a range of small-sized mills capable of much more accurate work than had been done on this type of machine. They applied the turret principle to 
the head carried on the cross rail and a few years later introduced a mill having a head carried on the side of the frame which permitted of the close working of the tools. These improvements transformed the boring mill into a manufacturing machine, and it became practically a vertical turret lathe with the advantages inherent in that type of machine. This trend toward the lathe type has finally resulted in a multiple station-type of machine which is in effect a vertical multi-spindle automatic chucking lathe with five independent tool heads, as shown in Fig. 56. Comparison of this with Fig. 15, shows how the lathe has developed in the 115 years since Maudslay introduced the slide-rest principle and the lead screw. 


\section{CHAPTER XV}

\section{ROBBINS \& LAWRENCE}

A glance at the genealogical chart, Fig. 37, will show why the old Robbins \& Lawrence shop, at Windsor, Vt., in the backwoods of northern New England, deserves a special chapter. When built, it was miles away from a railroad. It was never large, and the wheels of the original shop have long since ceased to turn, but few plants have had so great an influence on American manufacturing. Three brilliant mechanics, Lawrence, Howe and Stone, were working there in the early fifties, and from them and their successors came wholly, or in part, the vertical lathe turret, the miller, the profiler and a large number of the modern machines used in interchangeable manufacture. Of these three, Lawrence went to Hartford, Howe to Providence, while Stone remained at Windsor. In each case an important line of influence may be traced.

In the region about Windsor, sixty or seventy years ago, there were a number of small custom gun shops, and one firm, N. Kendall \& Company, was regularly making guns at the Windsor prison, using prison labor in addition to that of a number of free mechanics, who did the finer work. The history of the Robbins \& Lawrence Company begins about 1838, when Lawrence came to Windsor from the neighborhood of Watertown, N. Y. Fortunately he wrote out an account of his life shortly before his death, at the request of his son, giving a very interesting record of his early work and his connections 


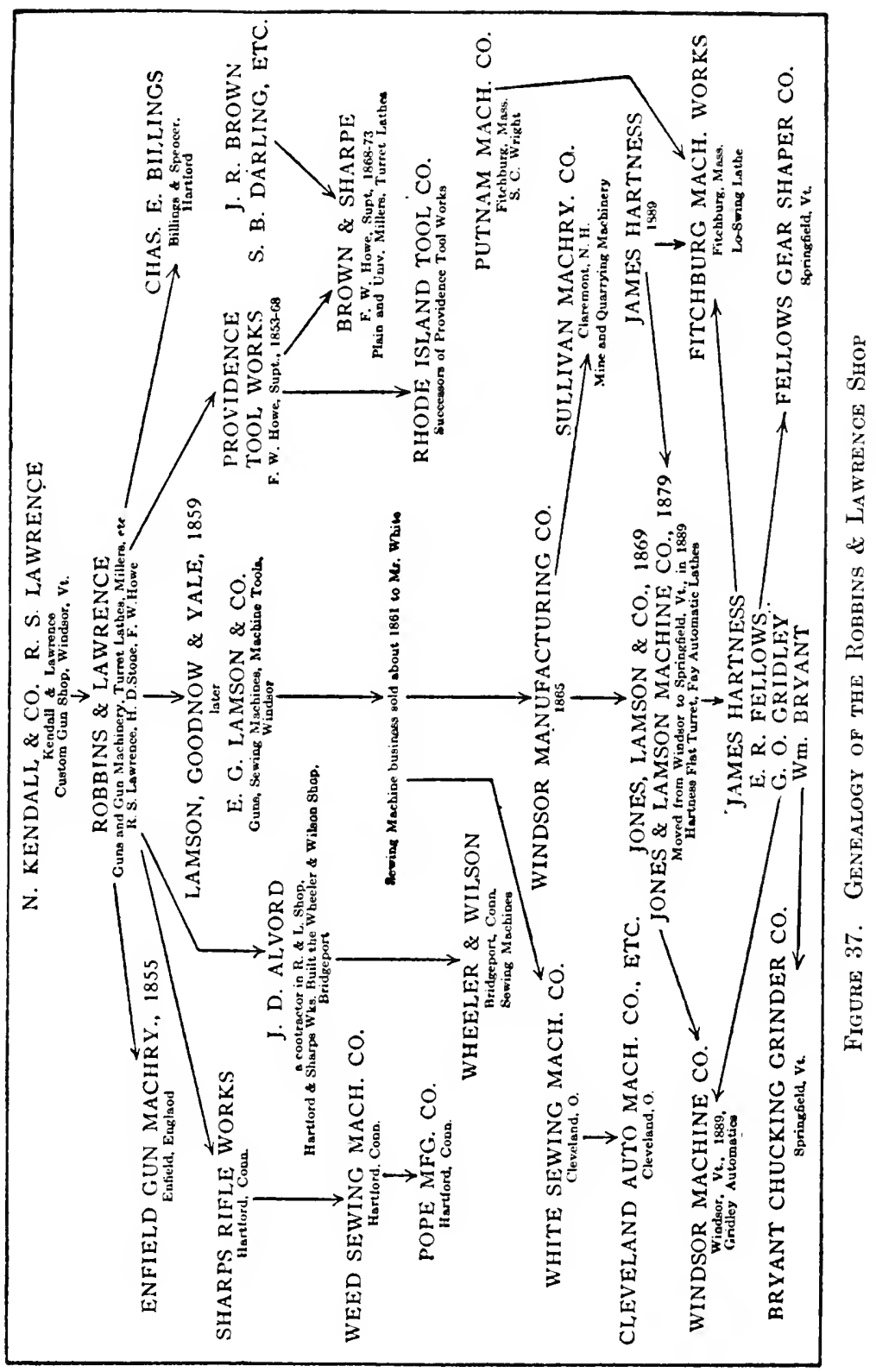


with his various manufacturing enterprises. This account shows clearly the integrity, modesty and worth of the man. ${ }^{1}$

Richard S. Lawrence, whose portrait appears in Fig. 40, was born in Chester, Vt., in 1817. When two years old, his father moved to Jefferson County, N. Y., and his boyhood was spent in the neighborhood of Watertown. He was only nine years old when his father died, and consequently he had a hard boyhood, with very little schooling, and was early at work in the support of the family. He worked on a farm and later in a woodworking shop, making carpenter's and joiner's tools. In the basement of this place was a custom gun shop, where he spent much of his spare time and became an expert gun maker. He worked with indifferent success at various jobs until the winter of 1837-1838, when he served in the United States army for three months, guarding the frontier during the Canadian Rebellion. At his discharge he determined to start in elsewhere for himself and thought of his relatives in Vermont. After a long journey by the Erie Canal, the newly built Albany \& Schenectady Railroad, and by stage, he reached Windsor in 1838.

A week or two after his arrival, while visiting a Doctor Story, he undertook to repair an old rifle, a "Turkey rifle," made by the doctor's brother in a gun shop in the neighborhood, and put on a peep-sight, a thing never heard of before in that neighborhood. He took the gun apart, leaded out the barrel, forged and finished the sight and put it on the gun. His skill in handling tools astonished those who watched him. Two days later, when the work was done, the doctor and Lawrence went out to try the gun. They paced off twelve rods from a maple tree which had a three-quarter-inch auger hole in

$1 \mathrm{By}$ the courtesy of Mr. Ned Lawrence this account is given in Appen. dix A. It has never been published before. 
it that had been used for a sap spout. Lawrence did the shooting. His own account of it is as follows: "The doctor tended target. Could find no ball hole. Said I missed the tree. I fired again, no ball hole to be found. Doctor came up to me and said I had spoiled his rifle. Before my repairs he could kill a chicken every time at twelve rods. I said, 'Uncle, I am very sorry, but I will make the gun all right before I leave it.' He said he could not consent to my doing anything more to improve the shooting qualities-the sight he liked very much. I said that as the gun was loaded I would take one more shot and see if I could not hit the tree. After the third shot I went up to the tree to investigate, and all of the three balls which I had fired were found in the auger hole." The doctor was astonished, for he had never heard of such shooting.

The next day he took Lawrence down to see N. Kendall \& Company, who were making guns at the Windsor prison. They hired him at once for two years at $\$ 100$ a year. His first work was stocking rifles by hand and the first day he put on five stocks. The next day the superintendent looked over the work and said it was well done, but it would never do to rush the work as he had, for he would "soon gun-stock them out of town," and he "must take it more easy." In the course of the next six months, he had so far mastered every process in the factory, even that of engraving in which he could soon compete with the oldest hands, that he was put in charge of the shop. Four years later the company gave up the gun business, and for a time Lawrence remained as foreman of the carriage department in the prison shop.

In 1843 Kendall and Lawrence hired a small shop in Windsor village and started a custom gun shop. In the winter of 1844 S. E. Robbins, a business man, came to

2 Quoted from the full account given in Appendix A. 
them and said that the Government was in the market for 10,000 rifles. The matter was talked over, a partnership formed, and a bid sent to Washington. In spite of the opposition of nearly all the other Government contractors, who said they could never do the work, it resulted in the award of a contract for 10,000 to Robbins, Kendall \& Lawrence, at $\$ 10.90$ each, attachments extra, to be furnished within three years.

They bought land, built a shop, and bought or made the necessary machinery. It was in the performance of this and the subsequent contract that many of the early machine tools were developed. The contract was finished eighteen months ahead of time, at a good profit, and they obtained a second contract for 15,000 at the same price. Soon after finishing the first contract, Robbins and Lawrence bought out Kendall's interest in the firm, which became Robbins \& Lawrence. The business proved very profitable. About 38 per cent of their work for the Government had to be rejected on account of poor material and workmanship, but the California gold excitement was then at its height and guns were in great demand. They were therefore able to sell their secondquality work for the full government price. About 1850 they contracted with Courtland C. Palmer for. 5000 Jennings rifles, a gun which later developed through the Henry rifle into the present well-known Winchester rifle.

About 1850 Robbins \& Lawrence took the first of the steps which led to their undoing. The railroad had just been completed through Windsor, and S. F. Belknap, a large railroad contractor, induced them to start in the car business, which, of course, had no rational relation with their main activity of building guns. $\mathrm{Mr}$. Belknap assured them that he could control all the car work in that section, and put in $\$ 20,000$ as a silent partner. The firm went to a large ontlay, but just as they 


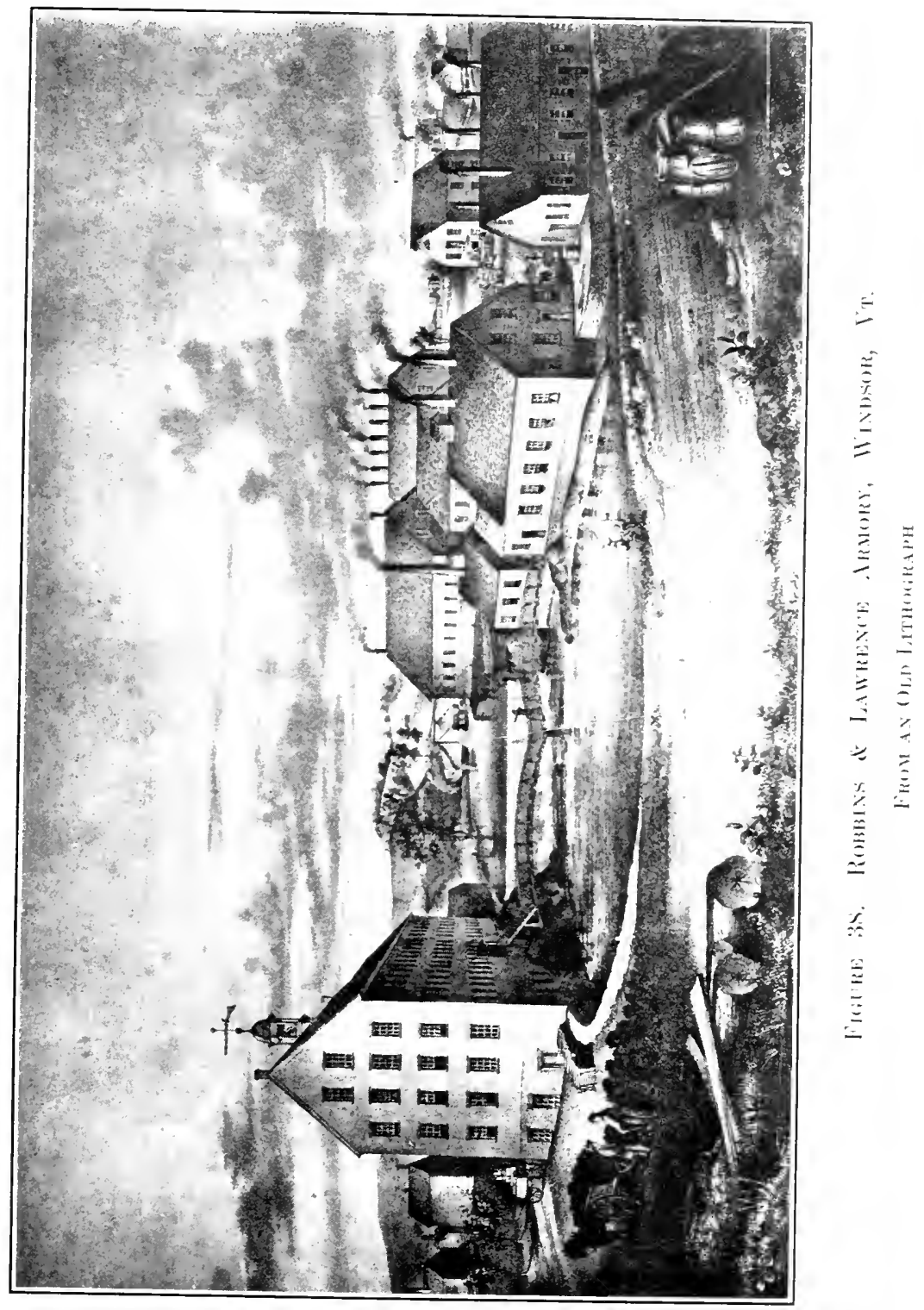




\section{.}


were finishing the first cars, Belknap quarreled with the president of the railroad and the firm could not sell a single car when they had expected to. After a considerable delay they were sold to other roads, and stock which proved valueless was taken in payment. The operation involved an actual loss of $\$ 134,000$, which was later increased to nearly $\$ 240,000$.

In all of their gun work, Robbins \& Lawrence used the interchangeable system, and they contributed very largely to its development. Lawrence, Howe, and later Stone, were constantly improving the methods of manufacture. Fitch's article on Interchangeable Manufacture in the U. S. Census Report of 1880, describes and illustrates a profiling machine built by Howe as early as 1848. The design shown there was used for many years throughout all the gun shops in the country. He also designed a barrel drilling and rifling machine, and he and Lawrence designed and built a plain miller, which was the forerunner of the well-known Lincoln miller. One of these millers, built in 1853, is still running in the shop of the North Brothers Manufacturing Company in Philadelphia. This machine had a rack-and-pinion feed for the table, which chattered badly when starting a heavy cut. The principal improvement which F. A. Pratt introduced in the Lincoln miller was the substitution for this of a screw and nut. The original drawing of this Robbins \& Lawrence machine is still on file in the office of the Jones \& Lamson Machine Company and shows clearly that it furnished the basis of the design of the Lincoln miller.

In 1851 Robbins \& Lawrence sent to the Exposition in London a set of rifles built on the interchangeable system, which excited great interest and for which they received a medal. This led to the visit of an English commission which resulted in a large contract to Robbins 
\& Lawrence for Enfield rifles, and for gun machinery which was installed in the Armory at Enfield, near London. It has been said that this contract caused the failure of Robbins \& Lawrence. This is not true.

In 1852 the company contracted to make 5000 Sharps carbines at Windsor, and 15,000 rifles and carbines at a plant which they were to erect in Hartford. The Sharps Company advanced $\$ 40,000$ to enable them to build a new factory and Mr. Lawrence moved to Hartford in 1853 to superintend the building and equipment of the plant. Shortly after it was completed, Robbins \& Lawrence, already strained by their losses in the carbuilding venture and with the erecting of the new plant, undertook a contract with Fox, Henderson \& Company for 25,000 Minié rifles. They were assured by the agent that he had in his pockets contracts for 300,000 more, which he promised them on the completion of the 25,000 . Lawrence objected strenuously to signing the contract for the 25,000 without more assurance as to the 300,000 to follow, as the outlay for the work would greatly exceed the profits on the first contract. It was signed, however, and it later developed that the agent had no authorization for the 300,000 . It was this which caused the failure of Robbins \& Lawrence.

Mr. Lawrence left the firm and took charge of the new Hartford plant which had been bought by the Sharps Rifle Company. J. D. Alvord, one of the contractors at Hartford under Lawrence, later built the Wheeler \& Wilson plant at Bridgeport. Robbins and others leased the Windsor shops and began the manufacture of sewing machines. In 1859 the plant and business were purchased by Lamson, Goodnow \& Yale, who retained Henry D. Stone as their mechanical expert. During the Civil War the plant was given over entirely to the manufacture of army rifles, and the sewing-machine business was 
sold to Mr. White of the White Sewing Machine Company of Cleveland, Ohio.

In the early thirties Silas Lamson had begun manufacturing scythe snaths in one of the hill towns of western Massachusetts. Up to that time the farmers had either used straight poles or those which happened naturally to have a convenient twist. Lamson conceived the idea of steaming the poles and bending them to a predetermined curve. About 1840 his sons, Nathan and E. G. Lamson, moved to Shelburne Falls and after some years began the manufacture of cutlery, founding the factory which has been in successful operation ever since. After the completion of the railroad through Windsor, they moved their snath factory to that place. They and their successors, the Lamson \& Goodnow Manufacturing Company, continued this work there for many years. When the Robbins \& Lawrence property was put on the market it was purchased by E. G. Lamson, A. F. Goodnow and B. B. Yale, under the name of Lamson, Goodnow \& Yale. E. G. Lamson \& Company and the Windsor Manufacturing Company succeeded this firm and continued the manufacture of machine tools and Ball and Palmer carbines, and completed a number of government rifle contracts. In $1869 \mathrm{R}$. L. Jones, a business man, of the Ascutney Mill at Windsor, joined the firm, which became Jones, Lamson \& Company, and a small cotton mill was added to their other activities. Ten years later the Jones \& Lamson Company was organized to take over the machine business. During all these changes Henry D. Stone continued as the designer. A large poster of the Windsor Manufacturing Company, printed some time about 1865, shows that they had plenty of irons in the fire, for they were prepared to furnish guns and machinery for manufacturing guns, sewing machines and needles, a standard line of hand-operated turret lathes, 
plain and index millers, planers, trimming presses, drill presses, sawmills, rock drills and mining machinery. Later their mining and quarry-machinery business was moved to Claremont, N. H., and became the Sullivan Machinery Company.

In 1889 the present Jones \& Lamson Machine Company moved to Springfield, Vt., where it now is. That same year, James Hartness entered the employment of the company as superintendent. With his advent the scattering of activities ceased and the Jones \& Lamson Machine Company began concentrating on turret lathes, which Robbins \& Lawrence and their various successors have been manufacturing continuously since the early fifties. A number of the old mechanics and foremen, who had homes in Windsor at the time the company was moving to Springfield, took over the old shops and organized the present Windsor Machine Company which now manufactures the Gridley Automatic Lathes.

This, briefly, is the history of the old Robbins \& Lawrence shop. The men, however, who worked with Robbins \& Lawrence and its successors, are of greater interest.

While Lawrence continued as master-armorer of the Sharps Rifle Works, the company was successful financially. Fitch, in the Census article frequently referred to, says that he brought with him "from Windsor the first plain milling machine used in Hartford." Lawrence also applied the broaching process to the manufacture of Sharps rifles, effecting great economies, and was the inventor of the split pulley which was first made for him at Lincoln's Phœnix Iron Works. In the winter of 1850 Lawrence introduced the practice of lubricating rifle bullets with tallow, making possible the repeating rifle which had been a failure up to that time as the barrel "leaded" and the gun lost its accuracy. This was 
done in connection with some trials of the Jennings rifle during the visit of Louis Kossuth, the Hungarian patriot, who was in this country for the supposed purpose of purchasing rifles. ${ }^{3}$ Mr. Lawrence left the Sharps company in 1872 and was for many years an official in the city of Hartford, as Superintendent of Streets and on the Water and Fire Boards. He died in 1892.

The Sharps Rifle Works, after Lawrence's retirement, were bought by the Weed Sewing Machine Company, and later by the Pope Manufacturing Company, who extended it greatly for the manufacture of the Columbia bicycle.

Frederick W. Howe, the second of the Robbins \& Lawrence mechanics mentioned, whose portrait appears in Fig. 39, learned his trade in the old Gay \& Silver shop at North Chelmsford. We have seen in a previous chapter the connection of this company, through Ira Gay, with the early mechanics at Pawtucket. It is an interesting and perhaps significant fact that both milling machines and turret lathes were in use in this shop, probably at the time when Howe worked there. Howe was first a draftsman and later superintendent at Windsor and was inti. mately associated with the designing there at that time. The Jones \& Lamson Machine Company still have drawings of machine tools made by him as early as 1848 . As both Lawrence and Howe were designing in the Windsor shop at that period, it is difficult today to apportion the credit between them.

When Robbins \& Lawrence failed, Howe went to Providence as superintendent of the Providence Tool Company and his work there contributed greatly to the success of that firm. While with both Robbins \& Lawrence and the Providence Tool Company, he worked on the turret-head screw machine and the plain miller.

s See Appendix B. 
The first screw machine brought out by Brown \& Sharpe in 1861 was built for Mr. Howe. Joseph R. Brown added certain valuable features to it, but the parts for the first machine were said to have been cast from Howe's patterns. Howe invented and built a universal milling machine, ${ }^{4}$ but it should not be confused with what is now known as the "universal" miller, which was first built by Brown \& Sharpe, also in 1861, for Mr. Howe to mill the flutes in twist drills. The distinction between these two machines has been pointed out by Mr. Burlingame. The No. 12 plain miller which Brown \& Sharpe build today was designed by Howe, and for many years was known as the "Howe" type of miller. From 1868 to $1873 \mathrm{Mr}$. Howe was the superintendent of Brown \& Sharpe, and built the first building on their present site. Later he started in business for himself as a consulting mechanical engineer and was designing a typewriter (which was never built) at the time of his death. He was a smooth-faced, welldressed man, with a restless inventive mind, apt to change things frequently, improving each time, however, and when he finished anything it was thoroughly done. He left a deep impress on mechanical development in this country, and while Lawrence was perhaps the best mechanic, Howe was probably the ablest of the three men connected with the early Robbins \& Lawrence history.

Henry D. Stone was born in 1815 and died at Windsor in 1898. He learned his trade as a millwright at Woodstock, Vt., but soon afterward came to Robbins \& Lawrence. He remained with them and their successors for the rest of his career, more than thirty years. He has been very generally credited with the invention of the

4 Illustrated in the American Machinist of August 13, 1914. See also p. 208. 

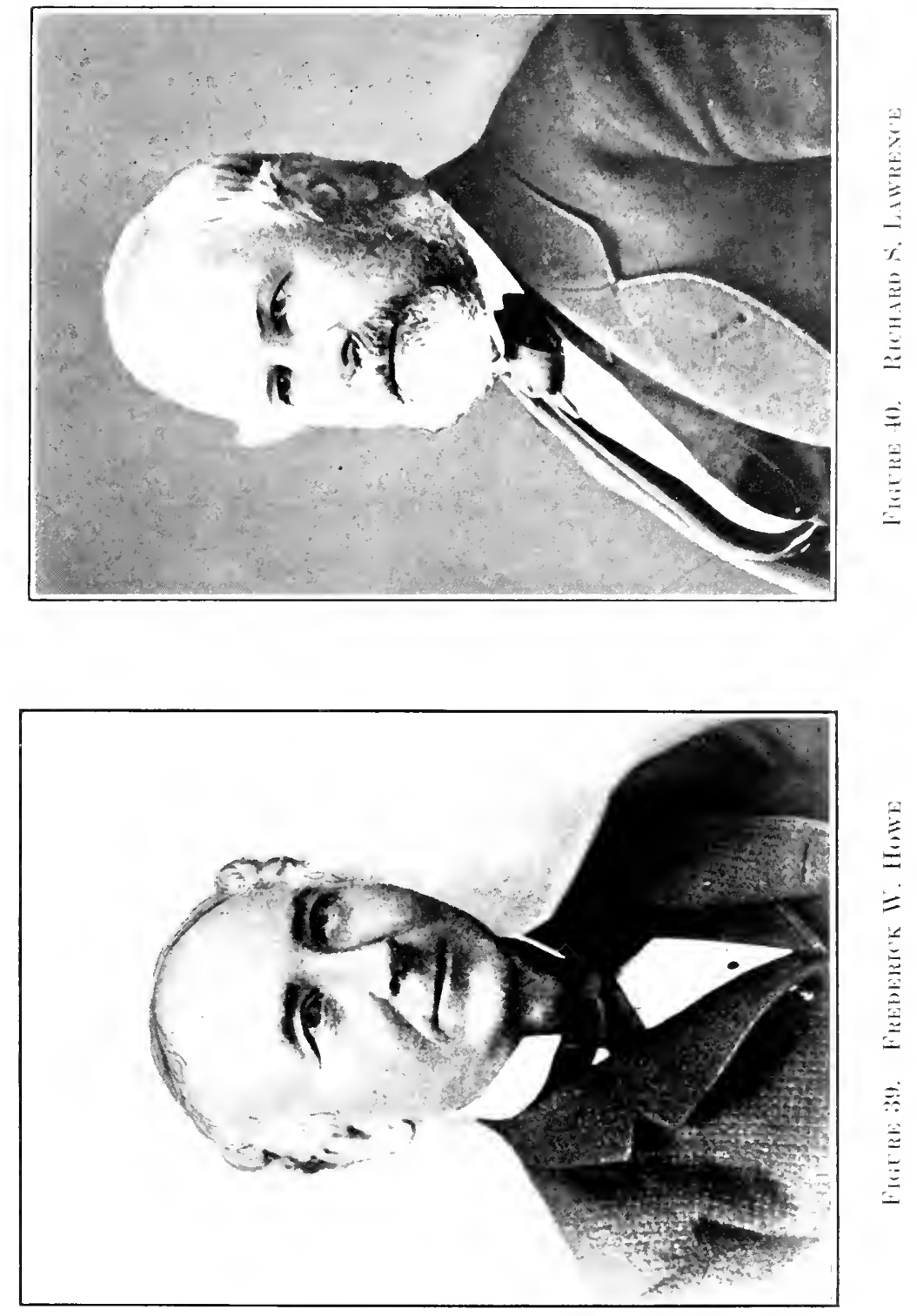

vertical turret as applied to the lathe, but the idea was by no means original with him. In 1845 a horizontal turret was designed and built by Stephen Fitch at Middlefield, Conn., to manufacture percussion locks for the United States Government. This machine is illustrated in the American Machinist of May 24, 1900 . It had a horizontal axis with eight positions for as many tools. In the same magazine for November 28, 1908, two turret lathes are illustrated and described, one with a vertical and the other with a horizontal turret, both of which were in use in the Gay \& Silver shop at an early date, probably in the forties, at the time Howe was there as an apprentice. The horizontal turret principle was also in use by E. K. Root at the Colt Armory, ${ }^{5}$ and J. D. Alvord is said to have used a turret screw machine in the Hartford plant in 1853. There is little doubt that both Howe and Lawrence had something to do with the development of the turret lathe at Windsor. The turret designs which Howe had built for him a few years later in Providence are all along the same lines. Stone unquestionably had a share in the development of the turret, for he made the drawing of the first Robbins \& Lawrence turret machines and continued for many years the development of the turret lathe for the various companies which successively operated in Windsor. With the turret screw machine came the box-tool and hollow mill. Machinery of May, 1912, illustrated and described a box-tool, fitted with two back rests and two cutting tools, which was made by Robbins \& Lawrence at Windsor in 1850.

The second period in the history of this company, or succession of companies, begins with the coming of James Hartness to the Jones \& Lamson Machine Com-

5 See Fig. 33. See also the valuable article by E. G. Parkhurst in the American Machinist, of May 24, 1900, p. 489, referred to above. 
pany in 1889. Mr. Hartness was born in Schenectady in 1861 and learned his trade by "picking it up," first with Younglove, Massey \& Company, of Cleveland, where his father was superintendent, and then in the machine shop of the Union Steel Screw Works. In the latter shop he first came in contact with close, accurate work. The practice of this company was due to Jason A. Bidwell, who came from the American Screw Company, in Providence, which we have referred to in a previous chapter. Three years later Mr. Hartness went to the Lake Erie Iron Works as tool maker. In 1882 he went to Winsted, Conn., as foreman in the Thomson, Stacker Bolt Company, and in 1885 to the Union Hardware Company of Torrington, manufacturers of gun implements, first as tool maker, then foreman, and later as inventor. During the year 1888 he worked for a few months at the Pratt \& Whitney shop in Hartford, at Scottdale, Pa., and with the Eaton, Cole \& Burnham Company, in Bridgeport. He went to the Jones \& Lamson Machine Company in February, 1889, the year in which they moved to their present location at Spring. field, Vt. He was first superintendent until 1893, then manager until 1900, and president from then on.

During these years Mr. Hartness has become one of the most influential designers of machine tools of this generation and in 1914 he was president of the American Society of Mechanical Engineers. When he went to Windsor, the Jones \& Lamson Machine Company was manufacturing principally a standard type of high-turret lathe, lever-operated, with power feed and back gears. Mr. Hartness immediately began an investigation of the problem which resulted in the invention of the Hartness flat-turret lathe and many improvements in the details of the tools used on it. While Mr. Hartness was developing certain details of the turret con- 


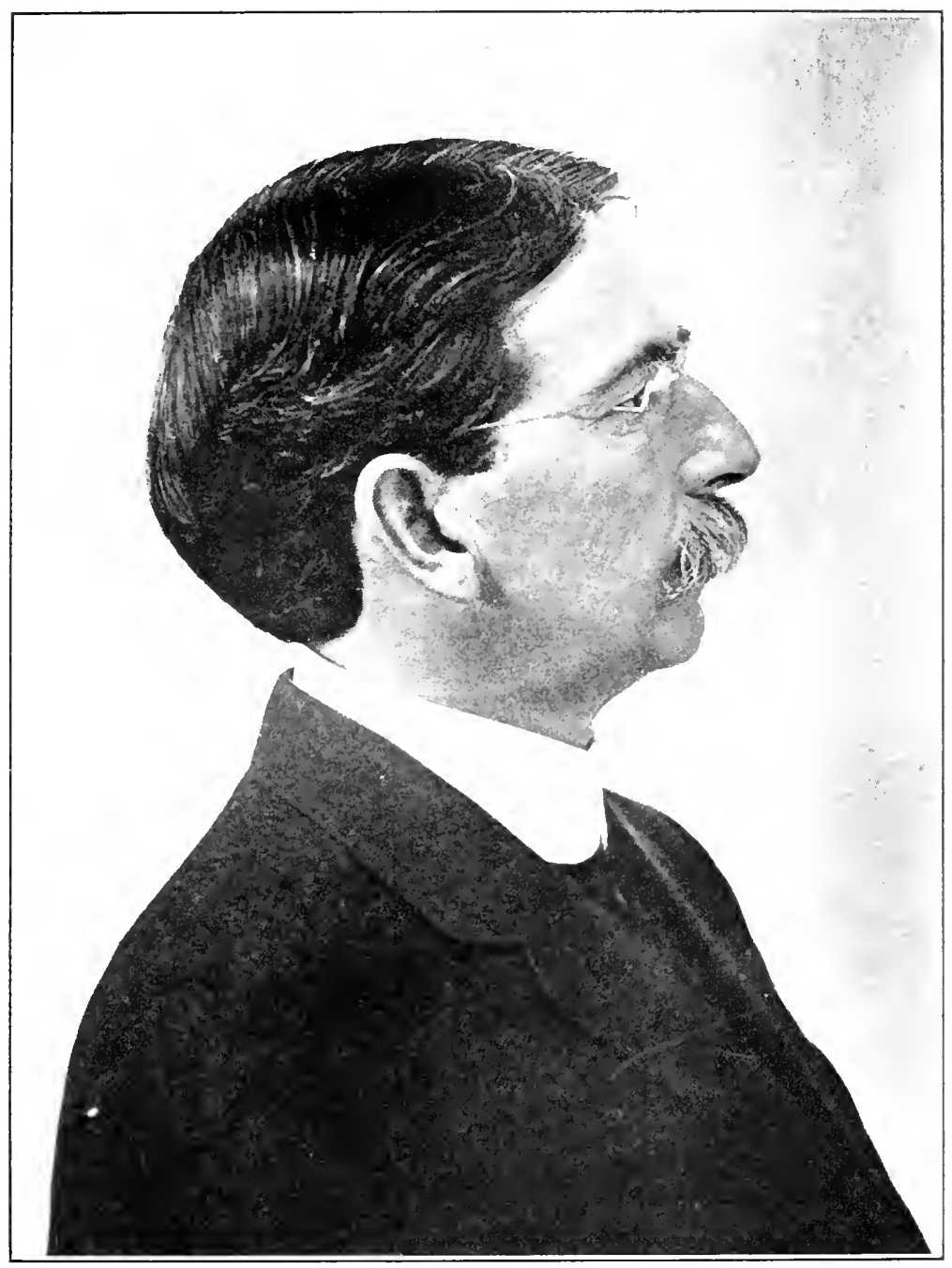

Figure 41. JaMES HARTNES 

struction, he found in the records of the company sketches of the identical mechanism, made by Howe nearly forty years before, which show not only that Howe was engaged in turret-lathe design but that he was a generation ahead of his time.

Under Mr. Hartness' management, the Jones \& Lamson Machine Company have concentrated on a single design of machine which they have developed to the utmost. Rather than be diverted from this single object, he has, as new inventions have come up, helped others to develop them independently. The result has been that while the Jones \& Lamson Machine Company, with one exception, has confined its attention to flat-turret lathes, a number of important machines, which have sprung from men connected with that company, are now being manufactured by other firms.

The Fellows gear shaper is one of these machines. Mr. Fellows' career is a problem to those who are interested in the training of mechanics. He was a window dresser in a dry goods store in Torrington and also ran the carpet department. When Mr. Hartness came to Springfield, Mr. Fellows, then twenty-two years old, came with him. Without any previous mechanical training or technical education he worked for one week in the shop, slotting screw heads, and then went into the drawing room. He succeeded so well here that in a short time ke was chief draftsman. In 1896 he invented his gear shaper, the Fellows Gear Shaper Company was organized, and has been in successful operation ever since. As the theory underlying this invention is of a very refined order and the problems involved in its manufacture have been worked out with great skill, one would expect it to be the product of long experience and high technical training. That Mr. Fellows should have brought out so refined a machine within a few years from 
the time he first turned his attention to mechanical matters is a remarkable tribute to his qualities as a machine designer.

Mr. George O. Gridley is another mechanic who worked under Mr. Hartness at Springfield. He developed the single- and later the multi-spindle automatic lathes which are now manufactured by the Windsor Machine Company in the new plant which has been built near the old Robbins \& Lawrence shop at Windsor. The original plant of the fifties is now used as a club house for the men.

The Lo-Swing lathe, manufactured by the Fitchburg Machine Works at Fitchburg, was invented by Mr. Hartness. The Fitchburg Machine Works was founded in the early sixties by Sylvester C. Wright, who came from the Putnam Machine Works. For many years they manufactured a general line of machine tools, but they now confine their attention entirely to the Lo-Swing lathe.

The Bryant chucking grinder, invented by William L. Bryant, is another machine which has sprung from the Jones \& Lamson shop of recent years. It is manufactured by a separate company, the Bryant Chucking Grinder Company, also at Springfield, Vt. The Fay automatic lathe, now manufactured by Jones \& Lamson Company, is the exception to their policy of concentration on the flat turret. Like the Lo-Swing, it is intended for work which cannot be done on the flat-turret lathe, more particularly such pieces as are carried on mandrels. The cutting tools are controlled by cams and a cam drum. Like the Lo-Swing, it is intended to supplement the field of the turret lathe and to give the advantage of multiple tools, constant setting, and automatic operation for work which could not be put upon a turret machine. 
We have followed the four main lines of influence from the old shop at Windsor; one, through Lawrence, to Hartford; one, through Howe, to Providence; one, through Stone and later Gridley, at Windsor; and the fourth, through Hartness and the Jones \& Lamson Machine Company to Springfield. Another line of influence comes through Charles E. Billings, who learned his trade under Robbins \& Lawrence, went to the Colt Armory, and as we have seen elsewhere, founded the Billings \& Spencer Company. Like Mr. Hartness, he also has been a president of the American Society of Mechanical Engineers. There are other lines of influence in Ohio, Pennsylvania and elsewhere which we cannot follow out here. 


\section{CHAPTER XVI}

\section{THE BROWN \& SHARPE MANUFACTURING COMPANY}

Two companies, both in New England, have been conspicuous for their leadership in tool building and the introduction of precision methods in manufacture. One of them, the Pratt \& Whitney Company, we have considered. The other, the Brown \& Sharpe Manufacturing Company, of Providence, calls also for special notice.

It was founded in 1833 by David Brown and his son Joseph R. Brown. ${ }^{1}$ For nearly twenty years its business comprised the making and repairing of clocks, watches and mathematical instruments, in a small shop without power. Its influence was hardly more than local and only fourteen persons were employed in 1853, when Lucian Sharpe was taken into the partnership, and the firm became J. R. Brown \& Sharpe. ${ }^{2}$

The real development of the business had begun a few years before. In $1850 \mathrm{~J}$. R. Brown had invented and built a linear dividing engine which was, so far as is known, the first automatic machine for graduating rules used in the United States. It was fully automatic, adapted to a wide variety of work, and provided with devices for correcting the inaccuracies of the machine as built, and such as might develop on account of wear.

1 David Brown retired in 1841. For the early history of David and Joseph R. Brown see Van Slyck: "Representative Men of New England."

2 The writer would acknowledge his indebtedness to Mr. L. D. Burlin. game for much of the material in this chapter. 


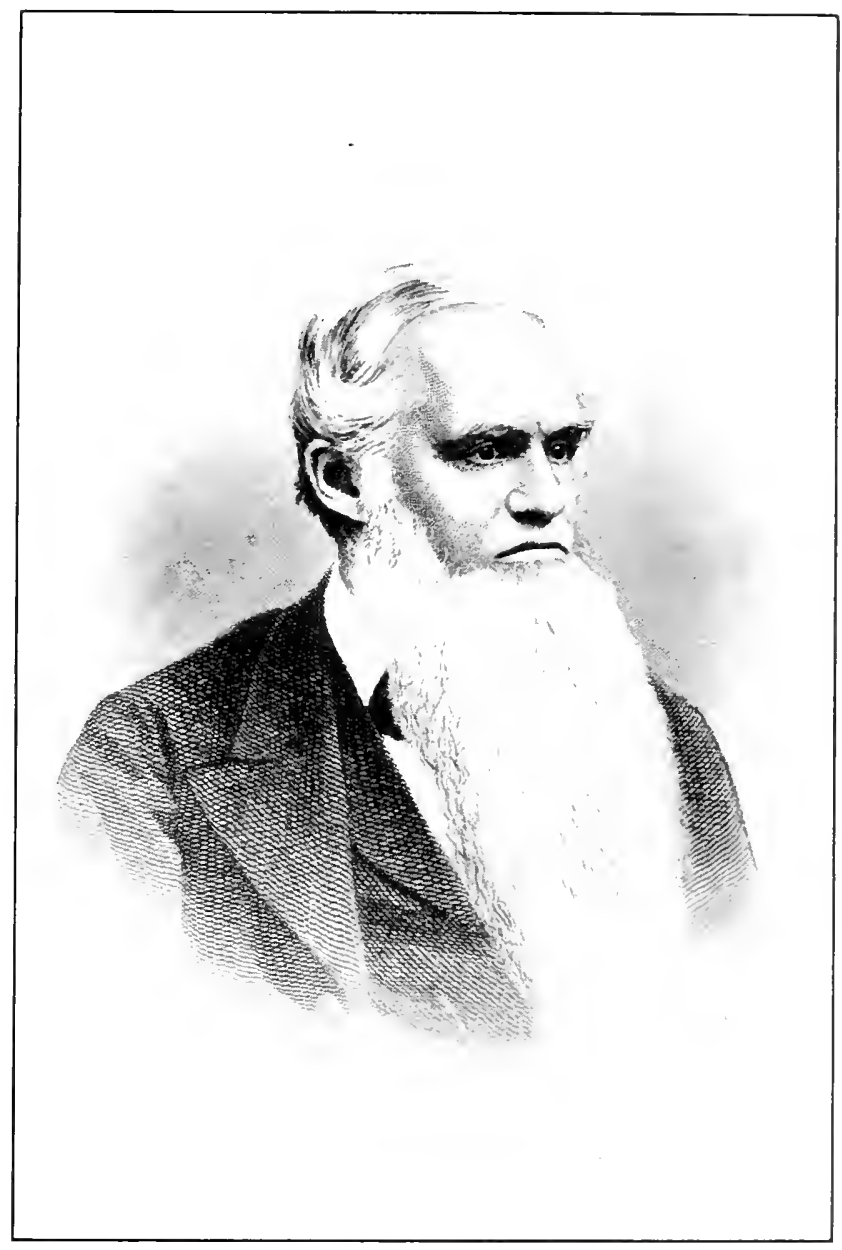

Figure 42. Jomeph R. Brow 

Various improvements were made in this machine within the next few years and two more were built, one in 1854 and one in 1859, essentially like it. These three machines are in use today and doing work which meets modern requirements of accuracy.

Soon after the first graduating machine was put into use, the vernier caliper, reading to thousandths of an inch, was brought out by Mr. Brown; the first was made as early as 1851. In the following year he applied the vernier to protractors. A writer, in speaking of the invention of the vernier caliper, says, "It was the first practical tool for exact measurements which could be sold in any country at a price within the reach of the ordinary machinist, and its importance in the attainment of accuracy for fine work can hardly be overestimated." The introduction of the vernier caliper was slow, only four being made in the first year. In $1852 \mathrm{Mr}$. Brown asked the New York agents to return one which they had on exhibition because he needed it for some fine work and did not have another in the shop. Within a year or two the sales improved, for Mr. Sharpe wrote his agent at Newark, N. J., in 1854, that it could not be expected there would be a market for many more tools in that neighborhood, as $\$ 500$ worth had already been sold there.

Mr. Brown did not have the market long, for in 1852 Samuel Darling also invented and built a graduating engine and began the manufacture of rules and squares at Bangor, Maine. Mr. Darling had been a farmer and sawmill owner, with a strong bent for mechanics. He had gone to work in a machine shop six years before and almost from the first had given his attention to improvements in machinists' tools. His first partner was Edward H. Bailey, but after a year a new partnership was formed with Michael Schwartz, a saw maker 
and hardware dealer of Bangor. They soon became active competitors of J. R. Brown \& Sharpe, and to this day mechanics here and there have scales marked "D. \& S., Bangor, Me." Competition between the two firms, both in prices and quality of work, became so keen that a truce was called in 1866, resulting in the formation of the partnership of Darling, Brown \& Sharpe, which conducted this part of the business until 1892, when Darling's interest was bought out. The entire business was soon after conducted under the name The Brown \& Sharpe Manufacturing Company, the original firm of J. R. Brown \& Sharpe having been incorporated under that name in 1868 .

In the spring of $1868 \mathrm{Mr}$. Darling moved to Providence, bringing with him his graduating engine, machinery and six of his most experienced workmen. Darling's engine was built along radically different lines from Brown's, an interesting feature being that many of its parts were made of saw-stock, which he also used as the material for his scales and squares. His machines and processes had been kept secret, and it was not until after the partnership was formed that Mr. Brown had opportunity of seeing them at Bangor. Mr. Darling's original dividing machine is also still running at the Brown \& Sharpe works, having been operated for over fifty years by John E. Hall, who remembers the time when Mr. Darling first brought his new partners to see it.

Both J. R. Brown \& Sharpe and Mr. Darling had had their standards compared with those at Washington prior to the formation of the partnership. Standards of a still higher degree of accuracy were prepared about 1877, and the following is quoted from a letter to J. E. Hilgard, of the Coast Survey Office, Washington, regarding the metric standard in use by the Brown \& Sharpe Manufacturing Company at that time: 
Taking 39.370 as the standard, there is only $0.00023 \mathrm{in}$. in the meter difference in our comparison, which perhaps is as close as may be expected. We shall now consider your comparison of our steel bar with the standard at Washington as correct, and in our comparisons with it shall be able to detect errors as small as 0.000025 in.

Still later and more accurate standards were made by Oscar J. Beale in $1893 .^{3}$

The early business of J. R. Brown \& Sharpe connected them closely with the various standards then in use for measuring wire, sheet metal, and the like. Mr. Sharpe was impressed with the irregularity and confusion of these various gauges, so that after he became Mr. Brown's partner, he interested himself in the establishment of a more systematic standard for wire gauges. In 1855 he corresponded with various people in regard to gauges for clock springs. By January of 1856 the wire gauge with a regular progression of sizes had been conceived, and a month later a table of sizes was made. The new system was laid before the Waterbury Brass Association by Mr. Sharpe, and in November of that year fifty gauges were sent to William Brown, president of the Association, for inspection by the members to show them the uniformity in size which could be maintained in making a number of gauges.

The Association passed resolutions adopting this standard, and in February, 1857, eight of the leading American manufacturers signed these resolutions. The new gauge, introduced to the public through a circular sent out in March of that year, became the standard, since known as the American Wire Gauge.

The subject of accurate gearing came up in connection with the clock business then conducted by J. R.

3 American Machinist, Vol. XXXVI, p. 1025. 
Brown \& Sharpe. There were also calls for gears to be cut which were beyond the capacity of the machine they then had for such work. This led to the design and building of a precision gear cutter, not only to produce accurate gears, but also to drill index plates and do circular graduating.

The second of the linear dividing engines, built in 1854, had a graduated silver ring set into the dividing wheel. This ring was graduated at the office of the Coast Survey in Washington by William Wurdeman on a machine having an index wheel with 4320 graduations copied from the plate of the Troughton \& Simms machine in London. Mr. Brown went to Washington to see the work done and was so well satisfied with it that he arranged with Mr. Wurdeman to graduate the copper ring used in the precision gear cutter which was built in 1855. Patrick Harlow, who operated this machine from about 1860 to 1910, says that it was Mr. Brown's special pride, that it was given the honor and care due a precision machine, was located in a room by itself and carefully covered every night to protect it from injury. Long after it was supplanted by automatic gear cutters, it was used for index drilling.

The formed milling cutter, which retains accurately the contour of its cutting edge through successive sharpenings, was invented in 1864 by J. R. Brown with special reference to the cutting of gear teeth. In fact, the oldest milling cutter known was used for cutting gear teeth. This cutter was made some time prior to 1782 by the French mechanic Jacques de Vaucanson and came into the possession of the Brown \& Sharpe Manufacturing Company about 1895 . The teeth are very fine and apparently were cut with chisels. The hole in the center is octagonal and seems to have been broached.

The formed cutters came as one of the important ele- 
ments in the system of interchangeable involute gears, introduced by Brown \& Sharpe, based on the principles of Professor Willis. While they used both the involute and cycloidal systems, they threw the weight of their influence toward the former and were a strong factor in the general adoption of the involute form for cut gearing, as well as for the use of diametral pitch, which, as we lave seen, was suggested by Bodmer in Manchester, England.

Early in the Civil War the Providence Tool Company took up the manufacture of Springfield muskets for the Government. Frederick W. Howe, who had become superintendent of that company after leaving Robbins \& Lawrence, had been designing turret machines for a number of years, as we have seen. In order to equip the Tool Company for this work, and especially for making the nipples, he went to J. R. Brown \& Sharpe and arranged with them to build a turret screw machine for this purpose. The general design of this machine was similar to those of Howe \& Stone, and Mr. E. E. Lamson tells the writer that the castings for it were made at the Jones \& Lamson shop in Windsor. J. R. Brown added the self-revolving turret, utilizing a ratchet and pawl action on the return motion of the slide, the device for releasing, feeding and gripping the bar-stock while in motion, and the reversing die holder. While Brown was the first to adapt these features to the Howe machine, the revolving feeding mechanism had been used before and Pratt \& Whitney had begun the manufacture of turret screw machines with self-revolving heads that same year, $1861 .^{4}$

This screw machine seems to have been the first machine tool built for sale by the Brown \& Sharpe Company. Various sizes of screw machines, of both hand 4 "'Origin of the Turret," American Machinist, May 24, 1900, p. 489. 
and automatic types, were built by them during and since the Civil War. In the early eighties, S. L. Worsley developed for them the complete automatic screw machine, many features of which are still in use in the machines now being built.

At the opening of the war plain milling machines had been in use for many years. The Lincoln miller had taken its present form and Howe had designed a miller with a vertically adjustable cutter-slide and a swiveling chuck which could be revolved, indexed and swiveled in two planes and fed longitudinally under the cutter. ${ }^{5}$ The statement by Fitch in the "Report on the Manufacture of Interchangeable Mechanism" in the United States Census, 1880, that the "universal miller" was designed by Howe in 1852, is doubtless based on this machine or a forerunner of it. The drawings of it, however, show a machine of radically different design from what is now known as the "universal miller," which was invented by Joseph R. Brown in 1861-1862, at Howe's suggestion.

The Brown \& Sharpe universal miller is indirectly connected with the-percussion nipple which brought about their first screw machine. The hole in this piece was drilled by twist drills which the Providence Tool Company were making for themselves. One day Howe came into the shop and watched the workman filing the spiral grooves in tool-steel wire with a rat-tail file. He decided that the method was too expensive and consulted with Joseph $\mathrm{R}$. Brown to find a better and more economical way of making them.

Mr. Brown appreciated the need of a machine to do this work, especially as he was just beginning to use such drills himself in the manufacture of the Wilcox \& Gibbs sewing machines. He set himself at once to the

- Illustrated in the American Machinist, Aug. 13, 1914, pp. 296.297. 


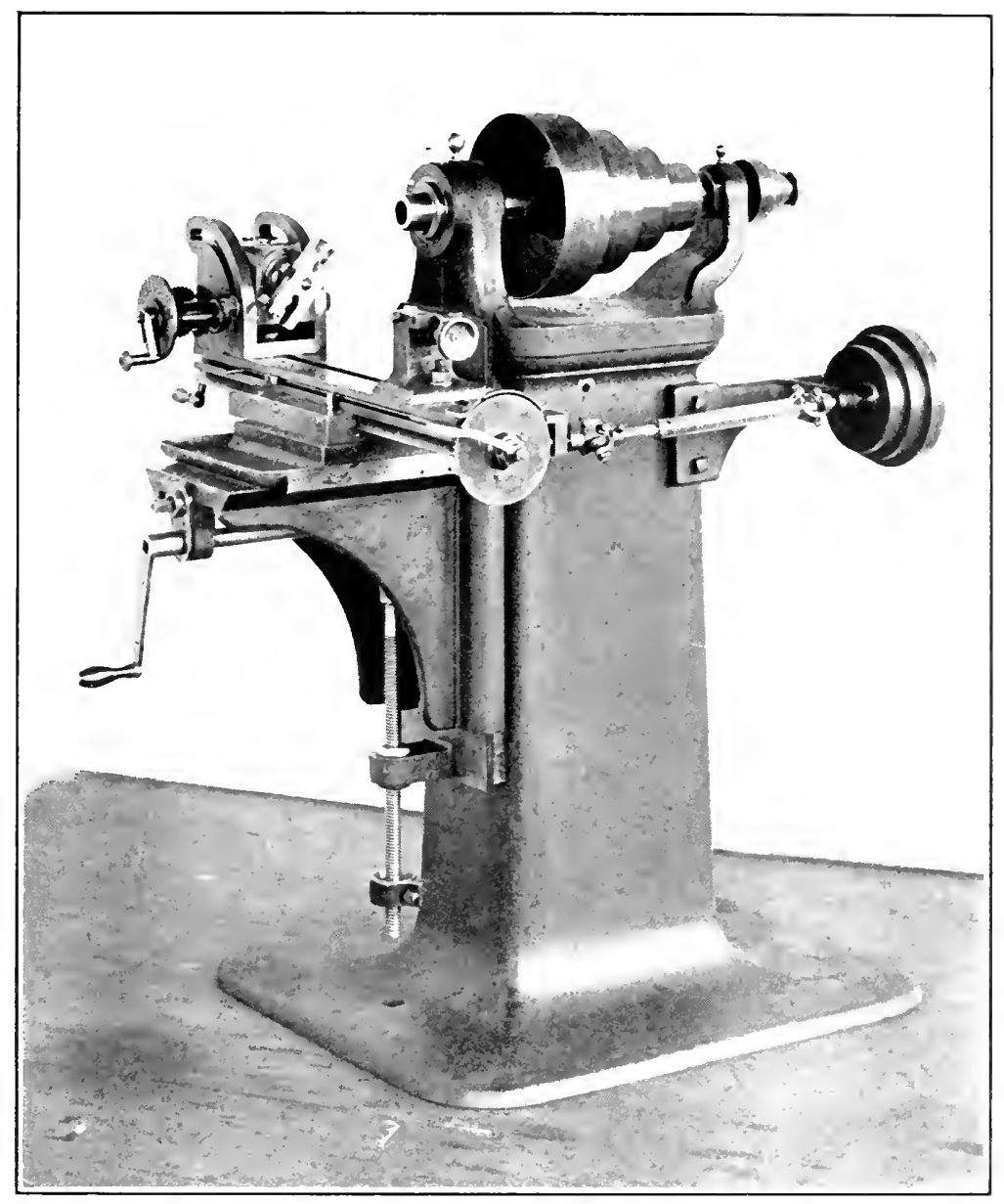

Figtre 43. First Cxiterate Millexg Marhine $1 \checkmark 62$ 


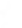


task of developing a machine which would not only cut the grooves in twist drills, but would be suitable for many kinds of spiral milling, gear cutting, and other work which had up to that time required expensive hand operations. Little time was lost, and the first machine (Fig. 43) was built and sold to the Providence Tool Company, March 14, 1862. After passing through several hands it came back thirty years later into the possession of its builders and is now preserved by them for its historical interest. The first published account of the machine appeared in the Scientific American, December 27, 1862. The limited facilities of the shop were taxed to meet the demand created, and ten machines were built and sold during the remainder of the year 1862 , most of the sales being in the eastern states. The first machine sold in the west went to the Elgin National Watch Company, and the first one sold abroad went to France.

Howe never claimed to be the inventor of this machine, and, in fact, while still superintendent of the Providence Tool Company he wrote a testimonial to J. R. Brown \& Sharpe, in which he said, "I take great pleasure in recommending your celebrated universal millers."

Howe was connected with the Brown \& Sharpe Company from January 1,1868 , to about 1873 . This is the last year that he appears in the directory as being at their works. There was some form of partnership by which he and Mr. McFarlane, the superintendent, had an interest in the business so that his name does not occur in its list of employees. The plain milling machine manufactured for years by Brown \& Sharpe is his design, and his work was partly that of special designing and partly superintending the building of their new plant on the present site. They moved into this in 1872 
from their old wooden buildings. At that time they employed from 150 to 200 men.

In the early sixties the company began the manufacture of the Wilcox \& Gibbs sewing machine, which they have manufactured ever since. They used cylindrical and caliper gauges, including limit gauges, for this work. In 1865 a set of standards was made for John Richards, and cylindrical and limit gauges of various forms were regularly manufactured during the early seventies. For a long time the basis of accuracy for these was a set of Whitworth plugs and rings, which are still preserved among their archives. The sizes above the 2 inch are castiron, and commencing with the $23 / 4$ inch they are hollow and ribbed. These were looked upon with reverence by the Brown \& Sharpe workmen and were used as master gauges for the commercial plugs and rings. They found, however, that in trying the Whitworth plugs, say $3 / 4$ inch and $1 \frac{1}{4}$ inch into a 2 inch ring and then other combinations into the same ring, an appreciable variation in fit could be noticed. This led to consideration of means for obtaining greater accuracy than was possible with dependence on these Whitworth gauges. At the time the question arose Richmond Viall had just become superintendent and Oscar J. Beale was chief inspector. It was decided to make a measuring machine which should be an original standard for measuring as well as a comparator. This machine, built in 1878, was largely the work of Mr. Beale. It has a measuring wheel graduated to read to ten-thousandths of an inch and a vernier reading to hundred-thousandths. There is also an adjustment which reads even finer than the famous "millionth dividing engine" of Whitworth. The basis of accuracy for the miscroscopic scale was a standard yard, which had been compared with the standards at Washington.

The micrometer caliper was introduced by Brown \& 
Sharpe in 1867. Although not the pioneers in the sense of being the inventors, they were the first to recognize the practical value of this tool for machinists, and to put it on the market. As in the case of the vernier caliper, the introduction of the micrometer caliper into everyday shopwork marked an important step in raising the standard of accuracy.

The principle is very old. William Gascoigne, of Yorkshire, England, used it about 1637, moving two parallel edges or pointers to and fro by means of a screw provided with a divided head. For two hundred years the principle has been used in controlling the movement of spider webs and cross hairs in transits and other optical instruments. It is well known that Watt had one (now in the South Kensington Museum in London), and we have already mentioned the "Lord Chancellor," used by Maudslay before 1830 . R. Hoe \& Company, of New York, in 1858, had a bench micrometer reading up to 9 inches. But none of these could ever have influenced mechanical standards generally as did the strong, compact little instrument developed by Brown \& Sharpe.

The circumstances surrounding its introduction are as follows: In 1867 the Bridgeport Brass Company had a lot of sheet brass returned to them from the Union Metallic Cartridge Company as "out of gauge." Investigation showed that the sheets were to the gauge of the manufacturer, but that the gauge used by the customer did not agree, and, further, when both gauges were tested by a third, no two of them agreed. All three gauges were supposed to be the regular U. S. Standard, adopted by the wire manufacturers in 1857, of the well-known round, flat form, with slits for the various sizes cut in the circumference. Gauges of this form were the best and most accurate method then known for measuring sheet metal. 
S. R. Wilmot, then superintendent of the Bridgeport Brass Company, seeing that the difficulty was likely to occur again, devised the micrometer shown at A in Fig. 44, and had six of them made by a skilled machinist named Hiram Driggs, under the direction of A. D. Laws, who was then in charge of the mechanical department of the Brass Company. The reading of the thousandths of an inch was given by a pointer and a spiral line of the same pitch as the screw, 40 to the inch, running around the cylinder and crossed by a set of 25 lateral, parallel lines. In the early part of 1867 , the matter was taken up with J. R. Brown \& Sharpe with a view to having them manufacture the gauges, and the one shown, $\mathrm{A}$, Fig. 44, with Mr. Laws' name stamped on it, is still in their possession. As submitted, the tool was not considered to be of commercial value, for the cylinder was completely covered with spiral and straight lines intersecting each other so closely that it was impossible to put any figures upon it, thus making it very difficult to read.

In 1848 Jean Laurent Palmer, a skilled mechanic in Paris, patented a "screw caliper," shown at B, Fig. 44, and began manufacturing it under the name of "Systeme Palmer." In this micrometer the graduations were divided, one set being on the cylinder of the frame and the other on the revolving barrel, an arrangement which permitted all the markings necessary for clearness. The importance of this tool does not seem to have been appreciated until August, 1867, when J. R. Brown and Lucian Sharpe saw one at the Paris Exposition. They at once recognized its possibilities and brought one home with them. To use Mr. Sharpe's own words: "As a gauge was wanted for measuring sheet metal, we adopted Palmer's plan of division, and the Bridgeport man's size of gauge, adding the clamp for tightening the screw and the adjusting screw for compensating the wear of end 
, 
of points where the metal is measured, and produced our 'Pocket Sheet Metal Gauge.' . . . We should never have made such a gauge as was shown us by the Bridgeport man in 1867, to sell on our own account, as it would be too troublesome to read to be salable. If we had not happened to find the Palmer gauge, and thereby found a practical way to read thousandths of an inch, no gauges would have been made. If we had never seen the Bridgeport device we should have found the Palmer at Paris, and without doubt have made such gauges, but possibly would have made a larger one first. The immediate reason of making the 'Pocket Sheet Metal Gauge' was the suggestion coming from the Bridgeport Brass Company of the want of a gauge of the size of the sample shown us for the use of the brass trade.",6

This gauge, shown at C, in Fig. 44, was put on the market in 1868, and appeared in the catalog of 1869 . Comparison of A, B, and C in Fig. 44 shows clearly their close relationship. The term "micrometer" caliper was first applied to the one-inch caliper (D, Fig. 44) which was brought out and illustrated in the catalog of 1877 . In Machinery of June, 1915, Mr. L. D. Burlingame has given an admirable and very complete account of the various improvements which have been brought out since that time. In connection with the article, a modern micrometer is shown and its various features, with the inventors of each, are clearly indicated. ${ }^{7}$

The cylindrical grinder was first made as a crude grinding lathe in the early sixties, and used for grinding the needle and foot bars of the Wilcox \& Gibbs sewing

6 From a letter of Lucian Sharpe, quoted in the American Machinist of December 15, 1892, p. 10.

7 The origin and development of the present form of micrometer is further discussed in Machinery, August, 1915, p. 999, and September, 1915, pp. 11, 58. 


\section{ENGLISH AND AMERICAN TOOL BUILDERS}

machines. In 1864 and 1865 the regular manufacture of grinding lathes was begun by using parts of 14-inch Putnam lathes modified to produce the automatic grinding lathes. These modifications consisted in mounting a grinding wheel on the carriage, providing an automatic feeding and reversing attachment, and included the use of a dead center pulley. From 1868 until 1876 various plans were worked out for a complete universal grinder, and by 1876 one had been built and was exhibited at the Centennial Exposition. The first one used at the factory was put into service a few days after Mr. Brown's death, which occurred July 23, 1876 . The patent granted to Mr. Brown's heirs for this machine included not only the ordinary devices of the universal grinder so well known today, but also provision for form grinding. The designing of surface machines as well as many other varieties followed, the work being done under the direction of Charles H. Norton, who later had charge of the design of their grinding machinery.

The manufacture of automatic gear cutters was commenced by the Brown \& Sharpe Manufacturing Company in 1877, two designs by Edward H. Parks, a small manufacturing machine for bevel and spur gears and the larger machine for general use, being brought out in that year.

In sixty years the Brown \& Sharpe Company has grown from an obscure local shop into a great plant employing thousands, but its influence and its product represent a greater achievement. Many mechanics of high ability have gone to other shops, among whom are Henry M. Leland, president of the Cadillac Motor Car Company; J. T. Slocomb, Horace Thurston, Elmer A. Beaman and George Smith, of Providence; Charles H. Norton, of Worcester; John J. Grant, of Boston; William S. Davenport, of New Bedford; A. J. Shaw, of the Shaw Electric Crane Company, and H. K. LeBlond, of Cincinnati. 
Hundreds of others, however, as managers, superintendents, chief draftsmen and tool makers, have perhaps done more to spread throughout the country the methods and standards of accuracy which have made American machine tools what they are.

Mr. Henry M. Leland, who was trained in the Providence shop, says :

The man who is responsible for this and who thoroughly demonstrated his rare ability and wonderful persistency in bringing out the accurate measuring tools and instruments, and the advanced types of more efficient and unique machinery, was the founder, Joseph R. Brown. I have often said that in my judgment Mr. Brown deserved greater credit than any other man for developing and making possible the great accuracy and the high efficiency of modern machine practice and in making it possible to manufacture interchangeable parts, because the Brown \& Sharpe Company were the first people to place on the market and to educate the mechanies of the country in the use of the vernier caliper. They were also the first to make the micrometer caliper.

I remember that in those early days people came to Brown \& Sharpe from all over the world to consult with Mr. Brown in reference to obtaining great accuracy and securing difficult results which had been deemed insurmountable by other highgrade mechanics. The mechanical engineers are now searching the records for men who have made themselves eminent in the industrial world as inventors and manufacturers; for a list of men to have honorable mention and to have their achievements and ability so recorded that the modern world may bestow upon them the credit and gratitude which they so richly deserve. Among these names I know of none who deserves a higher place than, or who has done so much for the modern high standards of American manufacturers of interchangeable parts as Joseph R. Brown. 


\section{CHAPTER XVII \\ CENTRAL NEW ENGLAND}

At the close of the chapter on "Early American Mechanics" we referred to the spread of machinery building northward from Rhode Island to the Merrimac Valley and central Massachusetts. This by no means implies that all the northern shops were started by Rhode Island mechanics, but their influence is so strong as to be clearly seen; and here, as in Rhode Island, the early shops were closely identified with the textile industry.

One of the first and most influential of these was the Amoskeag Manufacturing Company. The beginnings of the Amoskeag Company were made by a Benjamin Pritchard, of New Ipswich, N. H., who built a small textile mill at Amoskeag Village, then Goffstown, in 1809. In 1822 it was bought by Olney Robinson, from whom, that same year, Samuel Slater received a letter asking for a loan of $\$ 3000$. This was accompanied by a magnificent salmon as a sample of the products of Amoskeag. Slater, with the instincts of a good sportsman and a careful business man, went there to investigate, with the result that he bought the property, which then consisted of a water power, a two-story wooden mill and two or three small tenements. Larned Pitcher soon joined him, and in 1825 four other partners were taken in, Willard Sayles, Lyman Tiffany, Oliver Dean and Ira Gay. Three of the partners were Pawtucket menSlater, Pitcher and Gay. Slater and Gay were very 
influential in the early history of the company. The business grew rapidly and in 1841 they formed the Amoskeag Manufacturing Company, which has had a long and successful career. Their charter was broad, and they extended their operations until they included textile mills, extensive improvements of the water powers on the Merrimac, the founding of the city of Manchester, and the operation of a large machine shop.

The last, which interests us most, was started about 1840. At first it was used only for building and repairing textile machinery, but before very long it was actively engaged in the manufacture of steam boilers, locomotives, steam fire engines, turbine wheels and machine tools. It comprised two three-story shops, each nearly 400 feet long, with foundries and forge shops, and employed in all 700 men-a large plant for seventyfive years ago. William A. Burke, its first head, left in 1845 to organize the Lowell Machine Shop, which built textile and paper machinery and locomotives, and did general millwright work. One of the workmen who helped install the machinery in the Amoskeag shop was William B. Bement. He remained there for two years as foreman and contractor, and in 1845 joined Burke at Lowell. O. W. Bayley, who succeeded Burke as head of the Amoskeag shop, left in 1855 and founded the Manchester Locomotive Works.

Ira Gay came to New Hampshire from Pawtucket in 1824. Besides the Nashua Manufacturing Company and the Nashua Iron \& Steel Works, he and his brother, Ziba Gay, founded (about 1830) the Gay \& Silver Company, later the North Chelmsford Machine \& Supply Company referred to in a previous chapter. Frederick W. Howe, who did such important work with Robbins \& Lawrence, the Providence Tool Company, and Brown \& Sharpe, learned his trade in the Gay \& Silver shop. 


\section{ENGLISH AND AMERICAN TOOL BUILDERS}

It has been claimed that the shop of Gage, Warner \& Whitney, established by John H. Gage at Nashua in 1837, was the first one devoted exclusively to the manufacture of machine tools. If this is true, it does not involve as high a degree of specialization as would seem, for Bishop in 1860 says: "Their manufactures include iron planers of all sizes, engine lathes, from the smallest watch maker's up to a size suitable for turning locomotive driving wheels six or eight feet in diameter, hand lathes of all sizes, chucking lathes of all dimensions, with sliding bed, bolt cutting machines for rapidly transforming any part of a plain bolt into a nice, evenly threaded screw, upright and swing drills, boring machines for shaping the interior of steam cylinders, or other bores of large diameter, slabbers of all kinds, gear-cutting engines of all sizes for shaping and smoothing the teeth of gear wheels with perfect accuracy, power punching machines of various sizes, etc." In 1852 they began building steam engines. With all this formidable list, it seems never to have been a very large shop.

In 1825 the improvement of the water power at what is now Lowell was begun. Almost at the very begin. ning of this development work, a large machine shop was built and placed under the charge of Paul Moody, who was regarded as one of the foremost mechanies of his day and was an expert in cotton machinery. This shop was retained by the Water Power Company for nearly twenty years, when it was sold (1845) and reorganized as the Lowell Machine Shop under Burke's leadership. It employed at times one thousand men, and became one of the most important shops in the whole Merrimac Valley. James B. Francis, the great hydraulic engineer, began his life work as a draftsman here in 1 "Ifistory of American Manufactures," Vol. III, p. 451. 
1833; and later Bement became its chief draftsman, leaving it to go to Philadelphia.

From 1820 to 1840, other shops sprang up in the Merrimac Valley, such as C. M. Marvel \& Company, of Lowell, the Lawrence Machine Shop, and the Essex Machine Shop, where Amos Whitney, of Pratt \& Whitney, learned his trade, almost all of them building textile machinery, as well as machine tools. The output of these shops showed little specialization. They built almost anything which they could sell.

Of the Massachusetts towns, Worcester and Fitchburg seem to have been the first to develop successful shops producing machine tools only. In Worcester also the machinery trade had its beginning in the manufacture of textile machinery; in fact, Worcester antedates even Pawtucket in its attempts at cotton spinning, but these at first were unsuccessful. Practically all the early water privileges in and about the town, not used for sawmills, were used for textile mills. Prior to 1810 there was a small clock shop, some paper mills, and a few other enterprises, but they could hardly be dignified as factories. One of these was the old shop where Thomas Blanchard invented his copying lathe for turning irregular forms.

An Abraham Lincoln operated a mill and a forge with a trip hammer as early as 1795 . Here, in quarters rented from Lincoln, Earle \& Williams started, about 1810 , the first machine shop in the city. The town grew slowly and its interests were largely local. It was not until 1820 that Worcester took first rank even among the towns in the county. There was quite an excitement over the discovery of coal in 1823 . It was found, however, to be so poor, that, as someone put it at the time, "there was a sight more coal after burning it than there was before." The Providence \& Worcester 
canal was opened in 1828, but its usefulness for navigation was greatly limited by the many power privileges along its route. Its traffic was never large and it went out of business in 1848. It served, however, to hasten the building of the Boston \& Worcester Railroad, which was built by Boston capital to deflect the trade of the central Massachusetts towns from Providence to that city. It opened in 1835; and in 1836 there were listed in Worcester "seven machinery works," one wire mill and one iron foundry. Most of the earlier tool builders were trained in the small textile-machinery shops which had sprung up after 1810, such as Washburn \& God. dard's, Goulding's, Phelps \& Bickford's, White \& Boyden's. The rapid development of railroads created a demand for machine tools which the Worcester mechanics were quick to recognize, as had Nasmyth and Roberts in England.

Thomas Blanchard, who was born near Worcester, is one of the picturesque and attractive figures in our mechanical history. He was a shy, timid boy, who stammered badly, and was considered "backward." The ingenious tinkerer, laughed at by all, first secured his standing by devising an apple-parer which made a hit, social and mechanical. At eighteen he began building a tack machine and worked six years on it before he considered it finished. The essentials of its design have been little changed since. It made over two hundred tacks a minute and its product was more uniform and better than the hand-made tacks. Blanchard sold the patent for it for $\$ 5000$, a large price for those days, but only a fraction of its real value.

A few years later, about 1818, he invented the lathe for turning irregular forms which is associated with his name. It was first built for turning gun-stocks at the Springfield Armory, and the original machine (Fig. 
29 ) is still preserved there in the museum. Blanchard worked at the Armory for several years as an expert designer and invented or improved about a dozen machines for the manufacture of firearms, chiefly mortising and turning machines.

$\mathrm{He}$ was a fertile inventor and worked in many lines besides tool building. His principal income came from royalties on his "copying" lathe. Many stories are told of his ingenuity and homely wit. In his later life he was a patent expert. His keen mechanical intuitions, his wide and varied experience and unswerving honesty, gave weight to his opinions, and his old age was spent in comfortable circumstances. He died in 1864 .

In 1823 William A. Wheeler came to Worcester, and two years later he was operating a foundry. He did some machine work, and had the first steam engine and the first boring machine in Worcester, and also an iron planer "weighing $150 \mathrm{lb}$., $4 \mathrm{ft}$. long and 20 in. wide," the first one, it is said, in the state. Beginning with three or four hands, this foundry employed at times two hundred men. Its long career closed in the summer of 1914.

Samuel Flagg moved to Worcester from West Boylston in 1839, to be near the Wheeler foundry from which he got his castings. "Uncle Sammy Flagg" was the first man in Worcester to devote himself entirely to tool building, and is considered the father of the industry there. He made hand and engine lathes in rented quarters in the old Court Mills, which has been called the cradle of the Worcester tool building industry. His first lathes were light and crude, with a wooden bed, wrought-iron strips for ways, chain-operated carriage, and cast gears, as cut gears were unheard of in the city at that time.

His first competitor, Pierson Cowie, began making chain planers about 1845. After a few years he sold his 
business to Woodburn, Light \& Company, which in a few years became Wood, Light \& Company, one of the best known of the older firms. About the same time S. C. Coombs began making lathes and planers. Flagg meantime had organized the firm of Samuel Flagg \& Company, which included two of his former apprentices, L. W. Pond (whose portrait appears in Fig. 46) and E. H. Bellows. Pond later bought out Flagg and Bellows and developed the business greatly. It was incorporated as the Pond Machine Tool Company, in 1875, specialized in heavy engine lathes, and is now part of the Niles-Bement-Pond Company. Bellows went into the engine business, and Flagg started another enterprise, the Machinist Tool Company, which did not last long. It lasted long enough, however, to build one of the largest lathes made up to that time, 35 feet long with ways 8 feet wide.

From the old Phelps \& Bickford and S. C. Coombs shops came the two Whitcomb brothers, Carter and Alonzo, who formed the Carter Whitcomb Company in 1849, which became the Whitcomb Manufacturing Company in 1872. From the Coombs company also came successively Shepard, Lathe \& Company; Lathe, Morse \& Company, and the Draper Machine Tool Company. P. Blaisdell \& Company was founded in 1865 by Parritt Blaisdell, who had been fifteen years with Wood, Light \& Company; and S. E. Hildreth, who had worked for more than twenty years with Flagg and Pond, became a partner in this firm eight years later. The Whitcomb, Draper and Blaisdell companies were united in 1905 into the present Whitcomb-Blaisdell Machine Tool Company. From the old Blaisdell shop came also J. E. Snyder \& Son through Currier \& Snyder, who began building drills in 1833 and were both old workmen at Blaisdell's. The original Reed \& Prentice Company 


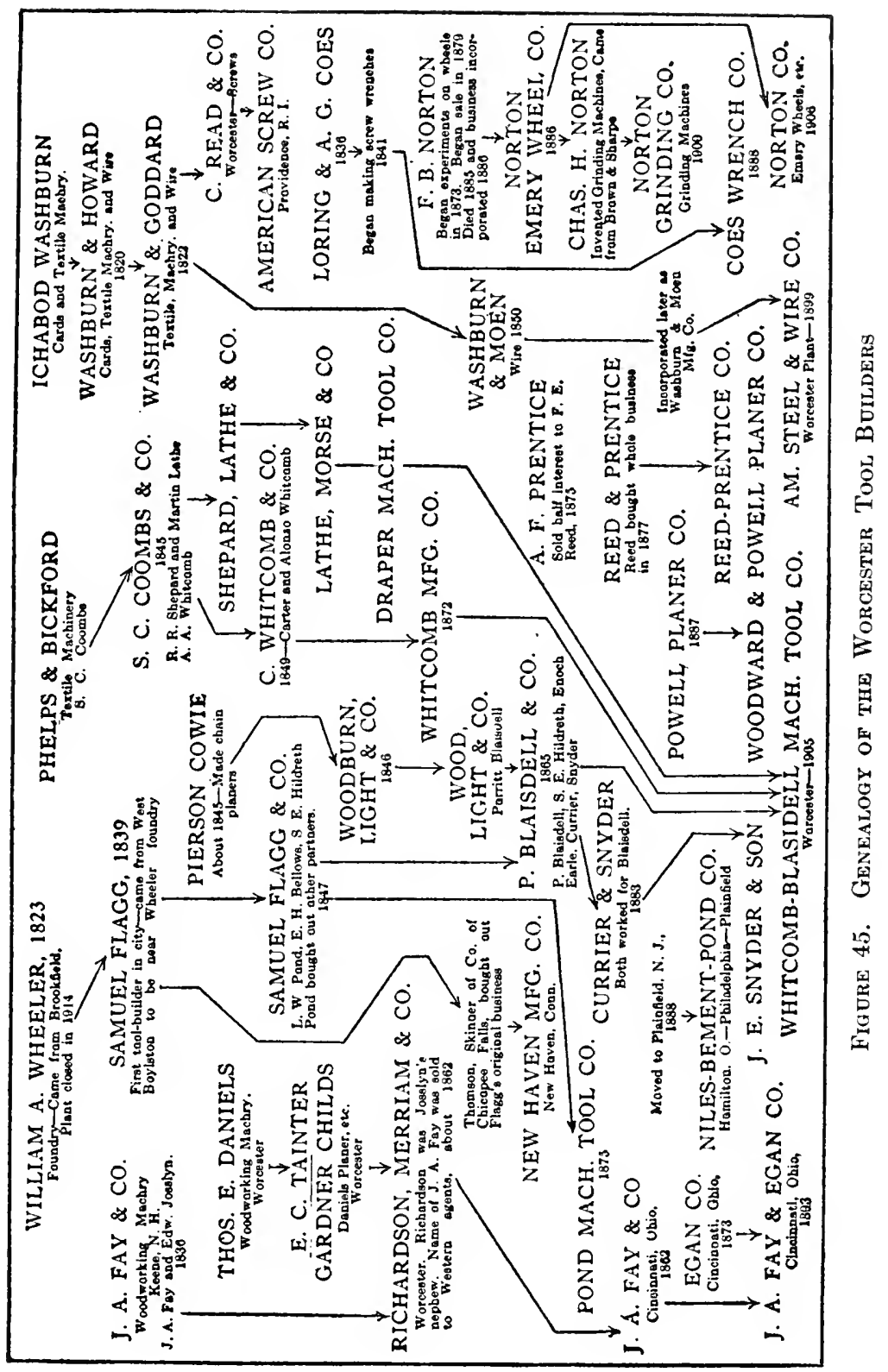


was started by A. F. Prentice, who sold a half interest to F. E. Reed in 1875 . The Woodward \& Powell Planer Company comes from the Powell Planer Company, incorporated in 1876. This maze of relationships is made clear by reference to the table given in Fig. 45 . The Norton Company comes from F. B. Norton, who began experimenting on vitrified emery wheels about 1873 and put them on the market in 1879. At his death the business was incorporated as the Norton Emery Wheel Company, now the Norton Company. Charles H. Norton's work in developing precision grinding has been perhaps the most distinguished contribution to the later generation of Worcester mechanics. $\mathrm{He}$ began work in the shops of the Seth Thomas Clock Company at Thomaston, Conn., under his uncle, N. A. Norton, who was master mechanic there for about forty years. At his uncle's death, Norton became master mechanic. He was with the Clock Company about twenty years in all, most of the time in charge of the design and building of all their tools, machinery and large tower clocks.

In $1886 \mathrm{Mr}$. Norton went to the Brown \& Sharpe Manufacturing Company of Providence as assistant to Mr. Parks, their chief engineer. Soon afterward he became designer and engineer for their work in cylindrical grinding machinery, remaining in that capacity for four years. In 1890 he went to Detroit with Henry M. Leland and formed a corporation called the LelandFalkner-Norton Company, Falkner being a Michigan lumber man. Associated with them was Charles $H$. Strellinger, a well-known dealer in tools and machinery. Six years later $\mathrm{Mr}$. Norton returned to Brown \& Sharpe and was again their engineer of grinding machinery until he went to Worcester in 1900. The Norton Grinding Company, organized that year and financed by men connected with the Norton Emery Wheel Company, have 
built cylindrical and plain surface grinding machinery designed by Charles $\mathrm{H}$. Norton, and under his direction have been leaders in refining and extending the process of precision grinding.

The Norton Company and the Norton Grinding Company should not be confused. The former make grinding wheels; the latter build grinding machines. Neither should F. B. Norton, who founded the grinding wheel industry and who died in 1885, be confused with Charles H. Norton, who did not come to Worcester until fifteen years later. There is no connection in their work, and despite the similarity of name, they were in no way related.

The greatest industry in Worcester is the American Steel and Wire Company, formerly the Washburn \& Moen Company. While it is no longer associated with tool building, it passed through that phase and traces back to the textile industry as well. It was founded by Ichabod Washburn, who started in as a boy in a cotton factory in Kingston, R. I., during the War of 1812. Making up his mind to become a machinist, he served an apprenticeship and then worked in Asa Waters' armory and with William Hovey, one of the early mechanics in Worcester. About 1820 he began the manufacture of woolen machinery and lead pipe in partnership first with Williain Howard and later with Benjamin Goddard. The enterprise prospered. As he was making cards for cotton and woolen machinery, he determined to manufacture the necessary wire himself by a new drawing process. His first experiments were a failure, but by 1830 they were successful enough to justify his undertaking regular manufacture. He superseded the old methods entirely and built up the present great business. Goddard retired, and, after various changes in partnership, Washburn took in his son-in-law, Philip L. Moen, 


\section{ENGLISH AND AMERICAN TOOL BUILDERS}

in 1850. By 1868 the firm employed more than nine hundred men, and wire drawing, which began as an incident in the manufacture of textile machinery, had become their sole activity. Today the works employ eight thousand men. In 1833 Washburn, in order to make an outlet for his wire products, induced the Read brothers to move to Worcester from Providence and begin the manufacture of screws. This business was operated separately under the name of C. Read \& Company. Later it was moved back to Providence, where it developed into the American Screw Company.

Worcester mechanics have made many things besides machine tools; in small tools and in gun work they have long been successful. The Coes Wrench Company was started in 1836 by Loring and A. G. Coes, and began to make the present form of screw wrench in 1841. Asa Waters, in Millbury near by, was one of the early American gun makers. After Waters came other gun makers, Ethan Allen, Forehand \& Wadsworth, Harrington \& Richardson, and Iver Johnson, who later moved to Fitchburg.

Much of Worcester's prominence as a manufacturing center is due to the unusual facilities it offered to mechanics to begin business in a small way. Nearly every manufacturing enterprise in the city began in small, rented quarters. There were a number of large buildings which rented space with power to these small enterprises; one of them, Merrifield's, was three stories high, 1100 feet long, and had fifty tenants, employing two to eight hundred men. Coes, Flagg, Daniels, Wood, Light \& Company, Coombs, Lathe \& Morse, Whitcomb, Pond and J. A. Fay, all began, or at some time operated, in this way. One is struck, in looking over the old records, with the constant recurrence of certain names, as the Earles, Goddards, Washburns, and realizes that 
he is among a race of mechanics which was certain sooner or later to build up a successful manufacturing community.

Fitchburg, while not so large or so influential, is almost as old a tool building community as Worcester. Its history centers about the Putnam Machine Company which was started by John and Salmon W. Putnam, who came from a family of mechanics. The latter's portrait appears in Fig. 47. They, too, began in cotton manufacturing, John as a contractor making cotton machine parts, and Salmon as a bobbin boy and later as an overseer at New Ipswich and Lowell. In 1836 they went to Trenton, N. J., intending to start a machine shop there, but the panic of 1837 intervened and made it impossible. They had themselves built most of the machines required; they stored these and found employment until business conditions improved. Finally, they started in a hired basement in Ashburnham, Mass., under the name of J. \& S. W. Putnam.

A year later they moved to Fitchburg and began repairing cotton machinery. At first they did their work entirely themselves, but their business increased rapidly and they soon hired an apprentice. Their first manufactured product was a gear cutter. This gave them a start and they soon developed a full line of standard tools. Though he was the younger brother, S. W. Putnam was the leading spirit. He first built upright drills with a swinging table so that the work could be moved about under the drill without unclamping. He designed the present form of back rest for lathes, and is said to have invented the universal hanger. The latter invention, however, has been claimed for several other mechanics in both England and America. In 1849 the brothers were burned out, without insurance. They repaired their machinery, built a temporary shed over 
it, and were at work again in two weeks. The present company was formed in 1858.

The Putnam company has been influential in other lines than machine tools. Putnam engines were for many years among the best known in the country, and the company was also intimately concerned with the early development of the rock drill, through Charles Burleigh, the head of their planer department and the inventor of the Burleigh drill. In fact, the first successful drills, those for the Hoosac tunnel, together with the compressors, were designed and built in the Putnam shops. Sylvester Wright, who founded the Fitchburg Machine Works, was for ten years foreman of their lathe department, and most of the old mechanics in and about Fitchburg were Putnam men.

Scattered here and there are other companies. At Nashua were Gage, Warner \& Whitney, to which we have referred, and the Flather Manufacturing Company which was founded by Joseph Flather, an Englishman, in 1867. The Ames Manufacturing Company of Chicopee Falls came from the old Ames \& Fisher shop at North Chelmsford. This was started by Nathan P. Ames, Senior, in 1791, who operated a trip hammer and other machinery, making edged tools and millwork. The shop was burned in 1810, and he moved to Dedham, Mass., for a year or so, but returned and resumed his former business on the old site. His sons, Nathan P., Jr., and James T., learned their trade with their father. The older brother, Nathan, moved to Chicopee Falls in 1829. James joined him in 1834. The Ames Manufacturing Company, formed the same year, lived for sixty years and employed at one time over a thousand men. From the start they had close relations with the Government and did an extensive business in all kinds of military supplies, swords, bayonets, guns, cannon, cavalry 


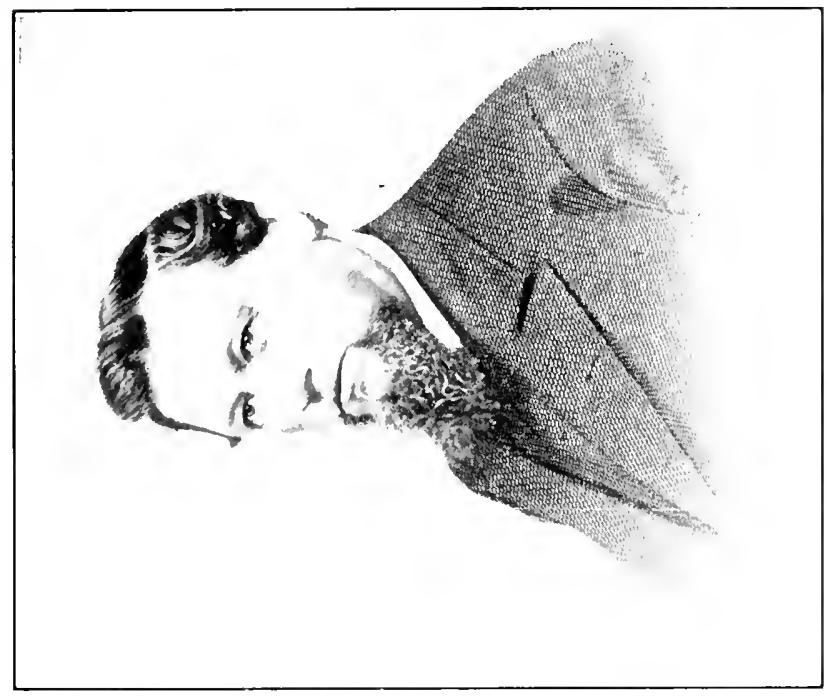

ב

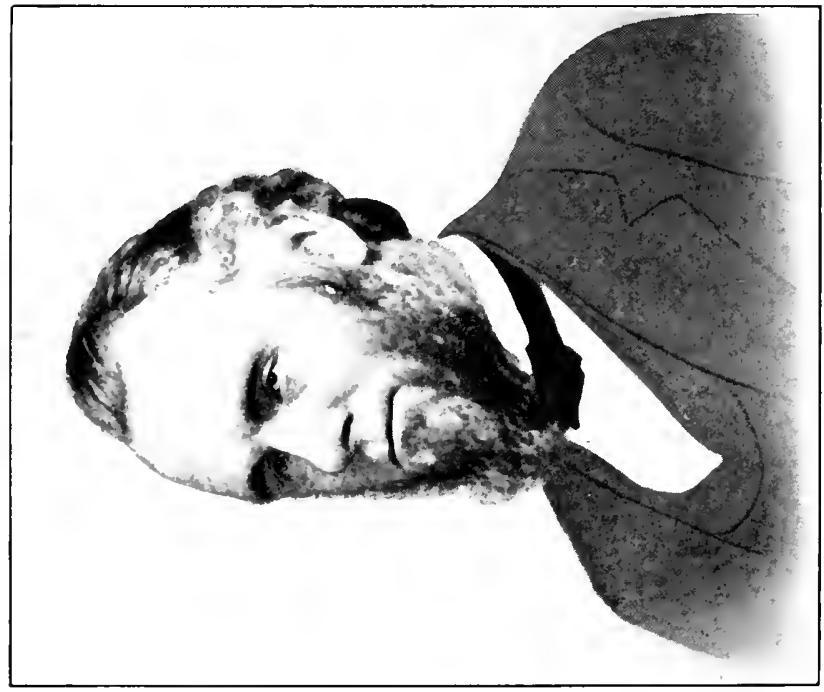

ב 


\section{.}


goods, etc. They cast bronze statuary, and the famous doors of the Capitol at Washington were made by them. They rivaled Robbins \& Lawrence in gun machinery and shared with them the order for the Enfield Armory. This contract alone took three years to complete. Their gun-stock machinery went to nearly every government in Europe.

In addition to all this they built the famous Boydon waterwheel, mill machinery, and a list of standard machine tools quite as catholic as that of Gage, Warner $\&$ Whitney. They did their work well, contributed material improvements to manufacturing methods and had one of the most influential shops of their day.

Most of the plants for manufacturing woodworking machinery can be traced back to a comparatively small area limited approximately by Fitchburg, Gardner, Keene and Nashua. This section was poor farming land, rough and heavily wooded, and the ingenuity of its inhabitants was early directed toward utilizing the timber. Mr. Smith, of the H. B. Smith Company of Smithville, N. J., came originally from Woodstock, Vt., and Walter Haywood started at Gardner. J. A. Fay and Edward Josslyn began manufacturing woodworking machinery as J. A. Fay \& Company at Keene, in 1836. In 1853 they felt the need of better facilities and purchased Tainter \& Childs' shop at Worcester, which was manufacturing the Daniels wood planer. Mr. Fay died soon after, and the business passed through the hands of H. A. Richardson, Josslyn's nephew, to Richardson, Merriam \& Company. They built up a good business before the Civil War, and had branch offices in New York, Chicago, and Cincinnati.

In the early sixties the western agents bought the name of J. A. Fay \& Company and started manufacturing at Cincinnati. Later this was united with the 
Egan Company, and the present J. A. Fay \& Egan Company formed. When J. A. Fay \& Company was started at Cincinnati, machinery, superintendent and mechanics were brought from Worcester, and, as the name implies, the present company was a direct descendant from the old Worcester and Keene enterprise.

Winchendon, in the center of the district referred to, has long been known for its woodworking machinery. Baxter D. Whitney began there before 1840. He died in 1915, aged ninety-eight years, the last of the early generation of mechanics. For many years he was a leader in the development of woodworking tools, and the business which he founded is still in successful operation under the management of his son, William M. Whitney.

Springfield, although an important manufacturing city, has had few prominent tool builders. One company, however, the Baush Machine Tool Company, has built up a wide reputation for drilling machines, especially large multiple spindle machines. 


\section{CHAPTER XVIII}

\section{THE NAUGATUCK VALLEY}

The most casual consideration of New England's mechanical development brings one squarely against a most interesting and baffling phase of American industrial life, the brass industry of the Naugatuck Valley. Here, in a narrow district scarcely thirty miles long, centering about Waterbury, is produced approximately 80 per cent of the rolled brass and copper and finished brass wares used in the United States, an output amounting to upward of $\$ 80,000,000$ a year. No concentration on so large a scale exists elsewhere in the country. For example, in 1900, Pennsylvania produced but 54 per cent of the iron and steel, and Massachusetts but 45 per cent of the boots and shoes. Furthermore, there seems to be no serious tendency to dislodge it. While there is more competition from outside, its ascendency is nearly as marked today as it was a generation ago. Why should this small district, a thousand miles or more from its sources of raw material, far from its market, and without cheap coal or adequate water power, gain and hold this leadership?

It was not the first in the field. The Revere Copper

1 The best study of the brass industry of the Naugatuck Valley has been made by William G. Lathrop, and has been published by him at Shelton, Conn., 1909, under the name of "The Brass Industry." Mr. Lathrop had intimate knowledge of the subject and, in addition, unusual facilities for investigation. The personal history of many of the men who have figured in its growth will be found in Anderson's "History of the Town and City of Waterbury,' 3 vols. 1895. 
Company, in Massachusetts, founded by Paul Revere, began rolling copper in 1801, and the Soho Copper Company, at Belleville, N. J., in 1813. The brass business in Connecticut had its origin with Henry Grilley, of Waterbury, who began making pewter buttons there in 1790. In 1802 Abel and Levi Porter joined him, and they started making brass buttons under the name of Abel Porter \& Company. In 1811 all the original partners retired and a new firm was formed, Leavenworth, Hayden \& Scovill. In 1827 Leavenworth and Hayden sold out to William H. Scovill, and the firm became J. M. L. \& W. H. Scovill. J. M. L. Scovill did the selling and his brother ran the shop and the finances. In 1850 the firm was incorporated as the present Scovill Manufacturing Company.

Meantime, Aaron Benedict established, in 1812, a factory at Waterbury for making bone and ivory buttons, and, in 1823, he too began making brass buttons. About 1820 James Croft, a brass worker from Birmingham, England, came to the Scovills. A year later Benedict secured him, and when Benedict and Israel Coe formed the firm of Benedict \& Coe, in 1829, Croft became one of the partners. Croft's coming marks a vital point in the history of the industry. On his advice, both Scovill and Benedict began to do their own rolling. It was his influence which induced them to import from Birmingham workmen, processes and machinery. $\mathrm{He}$ went to England seven times for Benedict, and Israel Hohmes went three times for Scovill to bring back English machinery, rollers and finishers. Israel Coe also went to England when the Wolcottville Brass Company was started. ${ }^{2}$ From that time, the business may be said to have passed the experimental stage, and its growth from 1830 was rapid.

2 Lathrop, p. 89. 


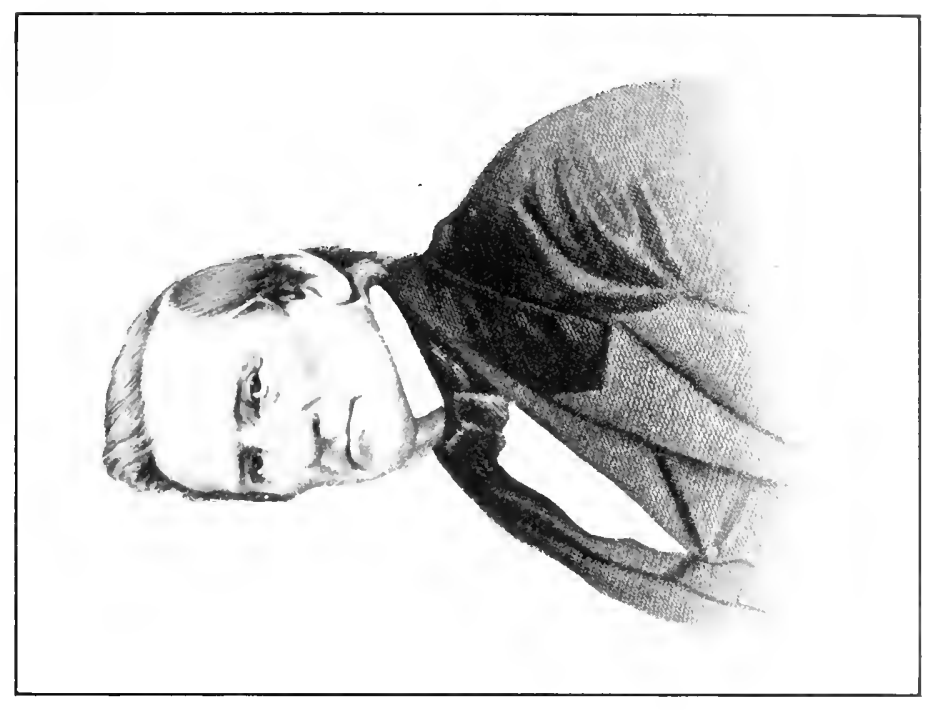

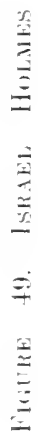

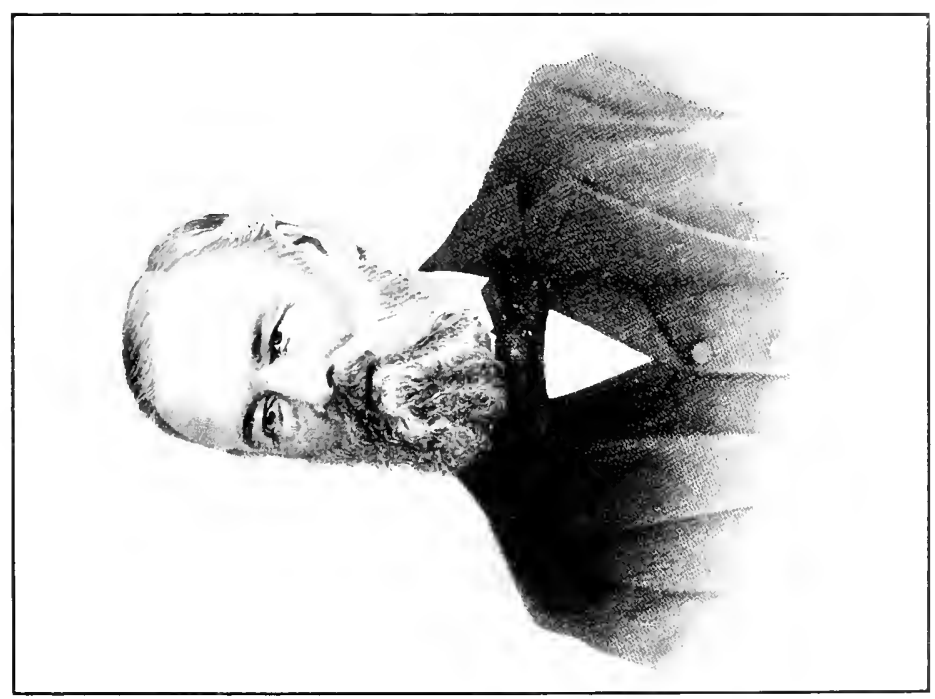

$=$

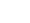

$=$

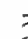

$\stackrel{3}{ }$

$\dot{+}$

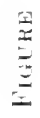



William Lathrop, who has made a study of it, has traced, perhaps better than any other, the coincident growth of the market and the industry. The raw material was at first mainly scrap copper, old ship sheathing, kettles, boilers and stills, collected by the Connecticut peddlers. More and more copper was imported until after 1850 when the mining of western copper began developing. All of the zine was imported until about 1870.

At first they rolled brass only for their own use, but new demands for it were arising. By 1840 Chauncey Jerome had developed the cheap brass clock. The discovery and refining of petroleum created a lamp industry. The pin machinery, invented by Dr. J. I. Howe, Fowler, and Slocum \& Jillson, opened up another great outlet. Daguerreotype plates gave another, and metallic cartridges another, while the invention of the telegraph enormously extended the use of copper wire. The Waterbury men were best able to meet these new demands, as they were the only ones in the country with the facilities and experience needed, and they "got in first." While the rolling and the drawing processes were imported bodily from England, and have continued almost unchanged, Yankee ingenuity was constantly at work devising new articles made of brass and improving the machinery for making the old ones.

With the increasing demand, firms began to multiply. Israel Holmes, who had been with the Scovills for ten years, started Holmes \& Hotchkiss in 1830, and with English workmen and machinery made wire and tubing for the market. After several changes in partnership, the firm became Brown \& Elton in 1838. Meantime, Holmes, with Israel Coe, Anson Phelps and John Hungerford, started the Wolcottville Brass Company in 1834, in what is now Torrington. They built up a prosperous business in sheet-brass kettles, but lost 


\section{ENGLISH AND AMERICAN TOOL BUILDERS}

heavily when Hiram W. Hayden, then with Scovill, invented the spinning process. Their property was eventually sold to Lyman Coe, and became the Coe Brass Company. The Waterbury Brass Company was started in 1845, with Holmes as president. Associated with him were H. W. Hayden, Elton, and Lyman Coe, son of Israel Coe. In 1853 Holmes founded Holmes, Booth \& Haydens, ${ }^{3}$ and in 1869 Holmes, Booth \& Atwood, which two years later was forced to change its name to Plume \& Atwood on account of its resemblance to the older company.

Israel Holmes stands out among the indomitable personalities who built up the brass industry. In addition to his invaluable work for the Scovills, he started five of the strongest firms in the valley, and was the first president of three.

Benedict \& Coe became Benedict \& Burnham in 1834, and from this firm has come the American Pin Company, the Waterbury Button Company and the Waterbury Clock and Watch companies. Anson Phelps soon withdrew from the Wolcottville Brass Company and started Smith \& Phelps at Derby in 1836. Encouraged by its success, Phelps planned to organize a large manufacturing community there, but he was held up by a man who raised the price of some necessary land from $\$ 5,000$ to $\$ 30,000$, so he moved two miles up the river and founded what is now the city of Ansonia. In 1854 the firm was incorporated as the Ansonia Brass \& Copper Company. Mr. George P. Cowles, who came from Wolcottville in 1848, was its executive head for forty years until his death. From it sprang the Ansonia Clock Company, of Brooklyn, Wallace \& Sons, which failed in 1896 and became part of the Coe Brass Company, and a num-

3 There were two Haydens in the firm, H. W. Hayden was in charge of the manufacturing and H. H. Hayden in charge of marketing the product. 


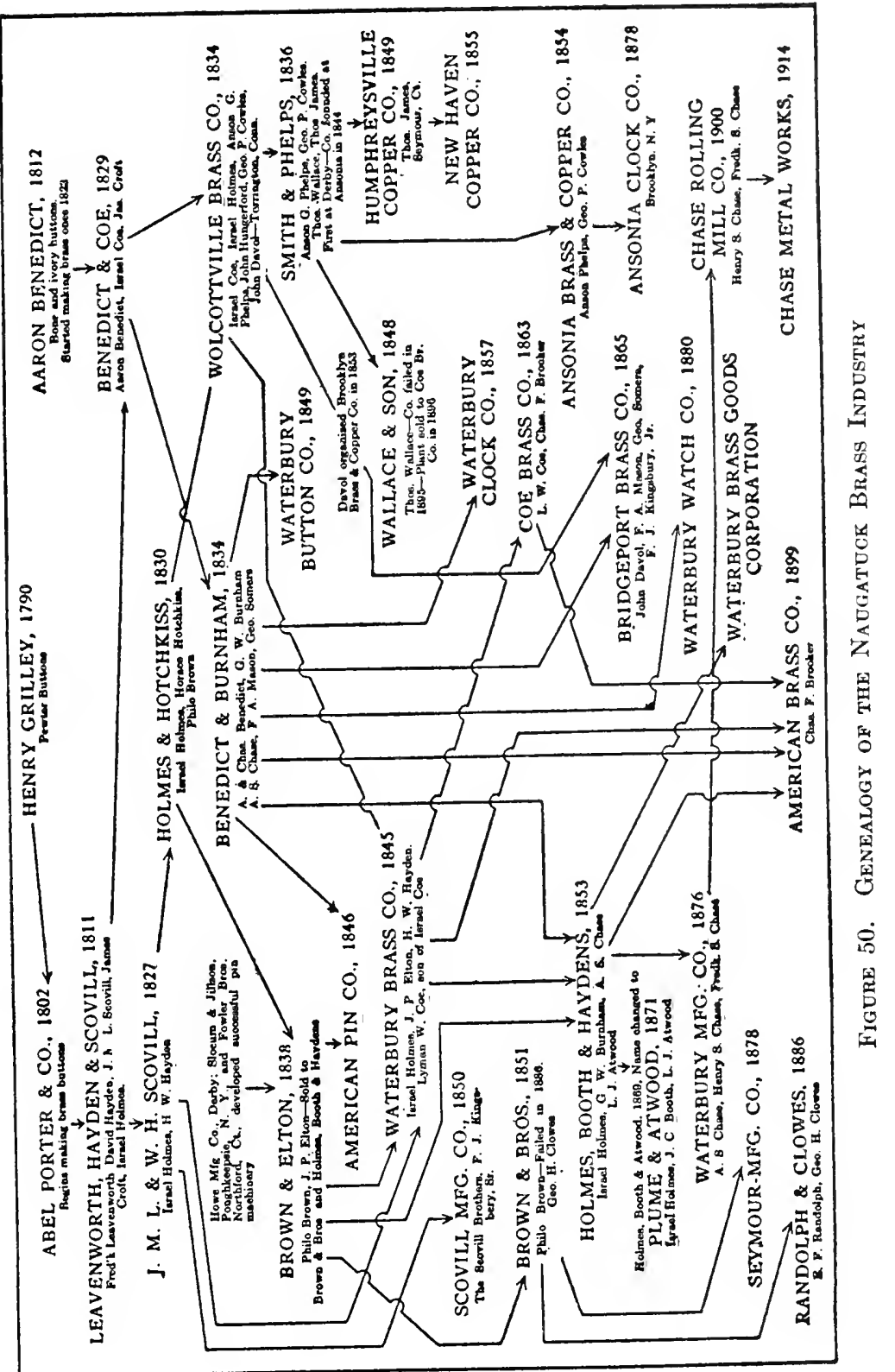


ber of other companies. The Chase Rolling Mills Company developed from the Waterbury Manufacturing Company, Benedict \& Burnham, and Holmes, Booth \& Haydens. Randolph \& Clowes came down through Brown \& Brothers, and Brown \& Elton from the old Holmes \& Hotchkiss firm.

The American Brass Company was formed in 1899, and now comprises the Waterbury Brass Company, Holmes, Booth \& Haydens, Benedict \& Burnham, the Coe Brass Company and the Ansonia Brass \& Copper Company. This is the largest brass company in the world.

Such, briefly, is an outline of the history of the larger companies. To an outsider their interrelations are almost inextricable. The chart (Fig. 50) does little more than indicate them. As phases of the business grew, there was a clearly defined policy of setting them off as separate enterprises. The American Pin Company, the Clock, Watch and Button companies, and the Brass Goods Corporation are examples. Only the more important of these manufacturing companies are shown. While there has been at times sharp competition among them, it always stopped short of war, and when facing outside competition the companies pull together.

Many of the heavy stockholders, as Holmes, Elton, Burnham and Chase, were interested in several companies. Nearly all of the leaders were born and grew up in the valley and were full of local spirit. Israel Coe, Holmes, the Scovill brothers and Phelps, of the earlier order, were men of great ability, as also Lyman Coe, Cowles and Charles F. Brooker, of the later generation. The inventions of Hiram W. Hayden vitally affected the history of four companies. They seriously undermined the old Wolcottville company, shut the Brooklyn Brass Company out of important phases of its 
business, and built up the prosperity of the Waterbury Brass Company, and Holmes, Booth \& Haydens. L. J. Atwood, of Holmes, Booth \& Haydens, and, later, Plume $\&$ Atwood, L. S. White, of Brown \& Brothers, and W. N. Weeden, of Benedict \& Burnham, were prolific inventors, and their work contributed to the growth of the industry.

Other influential men have built machinery for the large companies. Almon Farrel founded the Farrel Foundry \& Machine Company in 1851, and had two establishments, one in Ansonia and one in Waterbury. The Waterbury plant was operated for many years by E. C. Lewis as agent. He bought it in 1880 , but as a matter of sentiment retained the old name, prefixing the word Waterbury. The two plants have come to specialize somewhat, the Waterbury one building mainly presses and stamping machines, and the Ansonia one rolling mills and heavy machinery. E. J. Manville, an expert mechanic from the Pratt \& Whitney shop in Hartford, with his five sons, founded the E. J. Manville Machine Company, which has built up a wide reputation for its presses and headers. Among the many others are William Wallace of Wallace \& Sons, Ansonia, Charles Johnson and A. C. Campbell.

The answer, then, to our question as to origin and success of the Naugatuck brass industry is as follows. It sprang from the local manufacture of buttons. A small group of able, forceful and ingenious men developed the best facilities in the country for rolling and drawing brass, and when new demands came they were the only ones with experience prepared to meet them. They were originally well situated for raw material. Later they bought their copper in Baltimore. By the time copper began coming from the West, the Waterbury companies were firmly established. Copper is expensive, its unit of weight is the pound and not the 
ton, and freight rates are far less important than with steel, so the industry's detached location did not outweigh the advantage of its early start. A large force of workmen skilled in handling brass has been developed in these factories and no large enterprise could now be started elsewhere without drawing upon them. Many of these workmen own their homes, and their relations with the employers have generally been so friendly that higher wages elsewhere do not seem to attract them.

Finally, and perhaps most important of all, are the men who have designed and built the tools used. Connecticut leads all other states in the ratio of patents to the population, and Waterbury has led the rest of Connecticut in the proportion of nearly two to one. All the finishing or "cutting up" shops, as they are locally known, contain highly developed machinery-nearly all of it special, much of it designed and built in the shop where it is used.

This includes machinery for making eyelets, hooks and eyes, pins, cartridges, wire forming machinery, thread rolling, and headers and stamping machinery. Some of these machines, as, for instance, the last two mentioned, are more or less standard, but their tool equipment has been wonderfully developed and is bewildering in its variety. Much of this machinery has never been made public, and nearly all of it is too special, too intricate and too varied for description here. It is natural, under these circumstances, that the mechanics who developed these tools should be comparatively little known. They have, however, been a vital element in the Naugatuck brass industry, and should be recognized as successful American tool builders. 


\section{CHAPTER XIX}

\section{PHILADELPHIA}

Although the commercial manufacture of machinery began in New England, Philadelphia became, and for a long time remained, the largest tool building center in the country. Its large population and nearness to coal, iron and tide water, made this almost inevitable, but it was hastened by the work of two brilliant mechanics, William Sellers and William Bement.

Bishop, in his "History of American Manufactures," says: "In the invention and construction of machinery and instruments for practical and scientific purposes, Philadelphia mechanics early aequired a reputation for skill. The records of original American invention contain few names more distinguished than those of Godfrey, the inventor of the quadrant, of Rittenhouse, who made the first telescope constructed in America, and whose orrery and other scientific instruments displayed unusual mechanical and mathematical genius; of Franklin, Evans, Fulton, Fitch, and others whose inventive and constructive skill have added to the permanent wealth of the State and the Union." Of these, Oliver Evans seems to have affected modern manufacturing methods the most.

Evans was born in Delaware in 1755 . He was apprenticed to a wheelwright, and invented a card machine as early as 1777, but never followed it up. In 1785 he built a flour mill in Newcastle County, Del.; and, impa1 Vol. I, p. 576. 
tient at the crude methods in use, he began a series of improvements which form the basis of the modern art of handling materials. It has been claimed that Evans stole many of these ideas from the Ellicotts in Maryland. This does not seem probable. Thomas Ellicott wrote a portion of the "Millwright and Millers Guide", which Evans published to help introduce his machinery, and in this Ellicott himself refers to "the elevators, hopper-boys, etc., invented by Oliver Evans, late of Delaware, though now of Philadelphia." Evans developed a number of closely related transporting devices about which no question is raised and no claims on behalf of the Fllicotts made; and many years later, in 1812, Evans sued those Ellicotts who were then operating for infringement of his patents and obtained judgment. If they could have proved priority it seems natural that they would have done so.

Evans' improvements related chiefly to the movement of materials during the processes of manufacture. $\mathrm{He}$ modified the ancient Egyptian chain of pots, used for irrigation, by using an endless belt carrying iron buckets so arranged as to fill with dry material from a boot at the bottom and to empty by gravity into a hopper as they went over the head pulley. He used a belt conveyor for horizontal movement, without however the troughing feature which is a later improvement. When the discharge end was lowest, Fvans utilized gravity to drive it, and called it a "descender." What Evans called a "drill" was an "elevator laid horizontally" and provided with wooden cleats which scraped the grain along the bottom of the box in which it ran, and was nothing more nor less than our modern flight or scraper conveyor. Evans' "conveyor", was a round, wooden shaft on which he nailed a sheet-iron spiral which pushed the grain along a trough in which the 
shaft rotated; and when he wished to stir or dry the material as he moved it, he broke up the continuous helix into a number of separate arms arranged spirally. These of course correspond to the modern screw conveyor. His so-called "hopper-boy" consisted of a vertical shaft with a horizontal cross bar at its lower end provided on its lower side with flights which spread the meal for drying, and slowly worked it in a spiral toward a hopper at the center. The angle of the flights was adjustable so that the time allowed for cooling could be varied. He also used pivoted wooden spouts at the discharge of the elevators to deliver the grain into different bins. These improvements are said to have effected a saving of over $\$ 30,000$ a year in the Ellicott Mill at Patapsco, Md., on an ontput of 325 barrels a day. ${ }^{2}$ In his patents and various books Evans shows nearly all of the modern transporting devices in substantially their present forms. ${ }^{3}$

Evans moved to Philadelphia some time prior to 1790. In 1800 he had a mill near Third and Market Streets and the next year was selling mill supplies at Ninth and Market Streets. As a boy he had become interested in the steam engine. A description of the Newcomen engine fell into his hands and he was struck with the fact that the steam was used only to produce a vacuum and saw that more power conld be obtained if it were used to produce pressure. After his removal to Philadelphia he made an engine 6 inches diameter by 18 inches stroke, which was running in 1802, grinding plaster of Paris and sawing wood. It cost, boiler

2 Paper by Coleman Sellers on "Oliver Evans and his Inventions." Journal of the Franklin Institute, Vol. CXXII, p. 1.

3 Sections of Evans' mills are shown in the American Machinist of November 7, 1907, and December 17, 1914. In both cases the conveyor system was arranged to take material either from wagons on one side of the mill or from boats on the opposite side. 
and all, more than $\$ 3700$ and nearly impoverished him. Its successful operation, however, led to an order for an engine to drive a steamboat on the Mississippi, which was sent to New Orleans but never used for its original purpose. The boat it was intended for had been stranded high and dry during a flood, so the engine was set to running a saw mill and later a cotton press. In 1803 Evans began business as a regular engine builder and was unquestionably the first one in the United States. He advocated long stroke engines operating under high steam pressure, of which he had built fifty by 1816. In 1804 he built a flat bottomed boat, fitted with a steam driven, chain bucket dredge, which he called the "Oruktor Amphibolos" or in good English the Amphibious Digger. It was built more than a mile from the river, and was mounted on rollers connected with the engine. After moving around what is now the City Hall Square each day for several days, the boat walked out Market Street to the Schuykill and into the water; its rollers were disconnected, a stern paddle wheel substituted, and it steamed down the Schuykill and around up the Delaware to the city.

In 1805 he advertised a new book, "The Young Engineer's Guide," which he intended to be very complete and "abstruse." Disappointed in his application for the extension of his patents and crippled by his first engine ventures, he issued it much abridged, with only part of the illustrations planned, and called it "The Abortion of the Young Engineer's Guide." The proportions given in this book for one of his steam engines were: diameter of cylinder, 20 inches; stroke, 5 feet; steam pressure, 194 to 220 pounds. The boilers were of cast iron, 30 inches in diameter, 24 feet long, fired at one end, with a single return flue. An engine was actually built to these proportions for the Faimount Water Works. 
It may be added that the boilers burst on three different occasions.

In 1807 Evans was established as "Millwright and Engineer" at the Mars Works at Ninth and Vine Streets. An old description of the plant says that it consisted of

an iron foundry, mould-maker's shop, steam engine manufactory, blacksmith's shop, and mill-stone manufactory, and a steam engine used for grinding materials for the use of the works, and for turning and boring heavy cast or wrought iron work. The buildings occupy one hundred and eighty-eight feet front and about thirty-five workmen are daily employed. They manufacture all cast or wrought-iron work for machinery for mills, for grinding grain or sawing timber; for forges, rolling and slitting-mills, sugar-mills, apple-mills, bark-mills, \&c. Pans of all dimensions used by sugar-boilers, soap-boilers, \&c. Screws of all sizes or cotton-presses, tobacco-presses, paper-presses, cast iron gudgeons, and boxes for mills and wagons, carriage-boxes, \&c., and all kinds of small wheels and machinery for Cotton and Wool spinning, \&c. Mr. Evans also makes steam engines on improved principles, invented and patented by the proprietor, which are more powerful and less complicated, and cheaper than others; requiring less fuel, not more than one-fiftieth part of the coals commonly used. The small one in use at the works is on this improved principle, and it is of great use in facilitating the manufacture of others. The proprietor has erected one of his improved steam engines in the town of Pittsburg, and employed it to drive three pair of large millstones with all the machinery for cleaning the grain, elevating, spreading, and stirring and cooling the meal, gathering and bolting, \&c., \&c. The power is equal to twentyfour horses and will do as much work as seventy-two horses in twenty-four hours; it would drive five pair of six-feet millstones, and grind five hundred bushels of wheat in twenty-four hours. ${ }^{4}$

4 Freedley: "Philadelphia and its Manufactures," pp. 54-55. Philadelphia, 1858. 


\section{ENGLISH AND AMERICAN TOOL BUILDERS}

Incidentally the last sentence is an admirable illustration of the origin of the term "horse power." This business was carried on until Evans' death. It would be interesting to know how far he influenced the design of Mississippi river boat engines which have retained the proportions characteristic of the engines which he first built for that service.

Evans' best-known book, "The Young Millwright and Miller's Guide," went through a number of editions and was translated and published abroad. In this he gives his idea of "The True Path to Inventions." It is well worth quoting, as it explains, in part, his own success as an inventor.

Necessity is ealled the mother of Invention-but upon inquiry we shall find that Reason and Experiment bring them forth.-For almost all inventions have resulted from such steps as the following:

Step I. Is to investigate the fundamental principles of the theory, and process, of the art or manufacture we wish to improve.

II. To consider what is the best plan, in theory, that can be deduced from, or founded on, those principles to produce the effect we desire.

III. To inquire whether the theory is already put in practice to the best advantage; and what are the imperfections or disadvantages of the common process, and what plans are likely to succeed better.

IV. To make experiments in practice, upon any plans that these speculative reasonings may suggest, or lead to.-Any ingenious artist, taking the foregoing steps, will probably be led to improvements on his own art: for we see by daily experience that every art may be improved. It will, however, be in vain to attempt improvements unless the mind be freed from prejudice, in favour of established plans. ${ }^{.}$

s pp. 345-346. 
Evans was certainly an independent, and probably the first, inventor of the high pressure steam engine, a type of engine which he saw was well suited to American pioneer conditions. He was interested in steam locomotion, and predicted the development of railways with singular accuracy.

The time will come when people will travel in stages moved by steam engines from one city to another almost as fast as birds fly-fifteen to twenty miles an hour. Passing through the air with such velocity-changing the scenes in such rapid succession-will be the most exhilarating, delightful exercise. A carriage will set out from Washington in the morning, and the passengers will breakfast at Baltimore, dine at Philadelphia, and sup at New York the same day.

To accomplish this, two sets of railways will be laid so nearly level as not in any place to deviate more than two degrees from a horizontal line, made of wood or iron, on smooth paths of broken stone or gravel, with a rail to guide the carriages so that they may pass each other in different directions and travel by night as well as by day; and the passengers will sleep in these stages as comfortably as they do now in steam stageboats. A steam engine that will consume from one-quarter to one-half a cord of wood will drive a carriage 180 miles in twelve hours, with twenty or thirty passengers, and will not consume six gallons of water. The carriages will not be overloaded with fuel or water. . . And it shall come to pass that the memory of those sordid and wicked wretches who oppose such improvements will be execrated by every good man, as they ought to be now.

Posterity will not be able to discover why the Legislature or Congress did not grant the inventor such protection as might have enabled him to put in operation these great improvements sooner-he having asked neither money nor a monopoly of any existing thing. ${ }^{e}$

- Evans: Extract from "Address to the people of the United States," quoted in the Journal of the Franklin Institute, Vol. CXXII, p. 13. 
He practically initiated the modern science of handling materials. While many of his theories were faulty, his mechanical practice was seldom wrong. He was a restless man, discontented and inclined to air his grievances in public. Once, in a fit of pique, he destroyed the drawings and records of, it is said, more than eighty inventions-an act which he regretted later. Though frequently disappointed, he was in the end fairly successful, and was unquestionably one of the foremost of the early American mechanics.

In Philadelphia, as in New England, many of the early shops made textile machinery. Arkwright machines were built by James Davenport at the Globe Mills at the north end of Second Street, which Washington visited in 1797 when the new Federal Government inaugurated its policy of developing American industries. Davenport died soon after, the business ceased and the factory was sold in 1798. Cotton machinery is said to have been manufactured also by Eitonhead in 1803.

Philadelphia was then the largest city in the country, with an active industrial life. It was natural, therefore, that the tools and methods developed in and about Pawtucket should, sooner or later, take root there. In 1810 Alfred Jenks, a direct descendant of Joseph Jenks, of Lynn, having served his time with Samuel Slater in Pawtucket, moved to Holmesburg, Pa., and started the first factory in Pennsylvania for making textile machinery. His business grew rapidly and in 1820 he moved to Bridesburg, now a part of Philadelphia, bringing his shop along with him on rollers. By 1825 there were thirty cotton mills in and about the city, most of which he had equipped. As the demand for woolen machinery arose Jenks met it and he equipped the first woolen mill built in the state. Under his leadership and that of his 
son, Barton H. Jenks, the shop had a wide influence and was the foremost of the early Philadelphia plants building textile machinery. Other early shops in this field were those of J. \& T. Wood, Hindle \& Sons, James Smith \& Company, W. P. Uhlinger \& Company. ${ }^{7}$

The two plants which gave Philadelphia its great reputation for tool building were those established by Sellers and Bement. Probably no one has had a greater influence on machine tools in America than William Sellers. He has been called the Whitworth of America, and there is a singular parallelism in the work and influence of the two men. Sellers was born in Pennsylvania in 1824, was educated in a private school maintained by his father, and later apprenticed to his uncle, John M. Poole, at Wilmington, Del. ${ }^{8}$ When only twenty-one he took charge of the machine shop of Fairbanks, Bancroft \& Company in Providence, R. I. Three years later he began the manufacture of machine tools and mill gearing at Thirtieth and Chestnut Streets, Philadelphia, and was soon after joined by Edward Bancroft, who moved from Providence, the firm becoming Bancroft \& Sellers. John Sellers, Jr., a brother of William, became a partner and in 1853 they moved to Sixteenth Street and Pennsylvania Avenue. Mr. Bancroft died in 1855 and the firm became William Sellers \& Coinpany, which was incorporated in 1886, with William Sellers as president.

Bancroft was the inventive member of the firm and Mr. Sellers the executive. Sellers' designing ability did not develop until after Bancroft's death. His first patent was granted in 1857 . In all he was granted over ninety United States patents and many others in for-

7Freedley: “Philadelphia and its Manufactures," pp. 299-302, 427. Philadelphia, 1858.

8 Journal of the Franklin Institute, Vol. CLIX, pp. 365-383. 
eign countries, covering a wide variety of subjects; machine tools of all kinds, injectors which he introduced into the United States, rifling machines, riveters, boilers, hydraulic machinery, hoisting cranes, steam hammers and engines, ordnance, turntables, etc. One of the best known and most original of Sellers' machines was the spiral geared planer patented in 1862 , which has always been associated with his name.

Almost from the first Sellers cut loose from the accepted designs of the day. He was among the first to realize that red paint, beads and mouldings, and architectural embellishments were false in machine design. He introduced the "machine gray" paint which has become universal; made the form of the machine follow the function to be performed and freed it from all pockets and beading. Like Bement he realized that American tools then being built were too light; and they both put more metal into their machines than was the practice elsewhere. From the first he adopted standards and adhered to them so closely that repair parts can be supplied today for machines made fifty years ago.

In April, 1864, Sellers, as president of the Franklin Institute, read a paper on "A System of Screw Threads and Nuts," in which he proposed the system of screw threads since variously known as the Sellers, Franklin Institute, or U. S. Standard. ${ }^{9}$ They embodied the sixty degree angle and a flat of one-eighth of the pitch at the top and bottom of the thread. In this paper Sellers stated clearly the need for some generally accepted standard, reviewed the various threads then used, particularly the Whitworth thread, with its fifty-five degree angle and rounded corners, which he disapproved of on three grounds; first, that it was difficult to secure a fit at the top and bottom; second, that the angle was diffi-

9 Journal of the Franklin Institute, Vol. LXXVII, p. 344. 


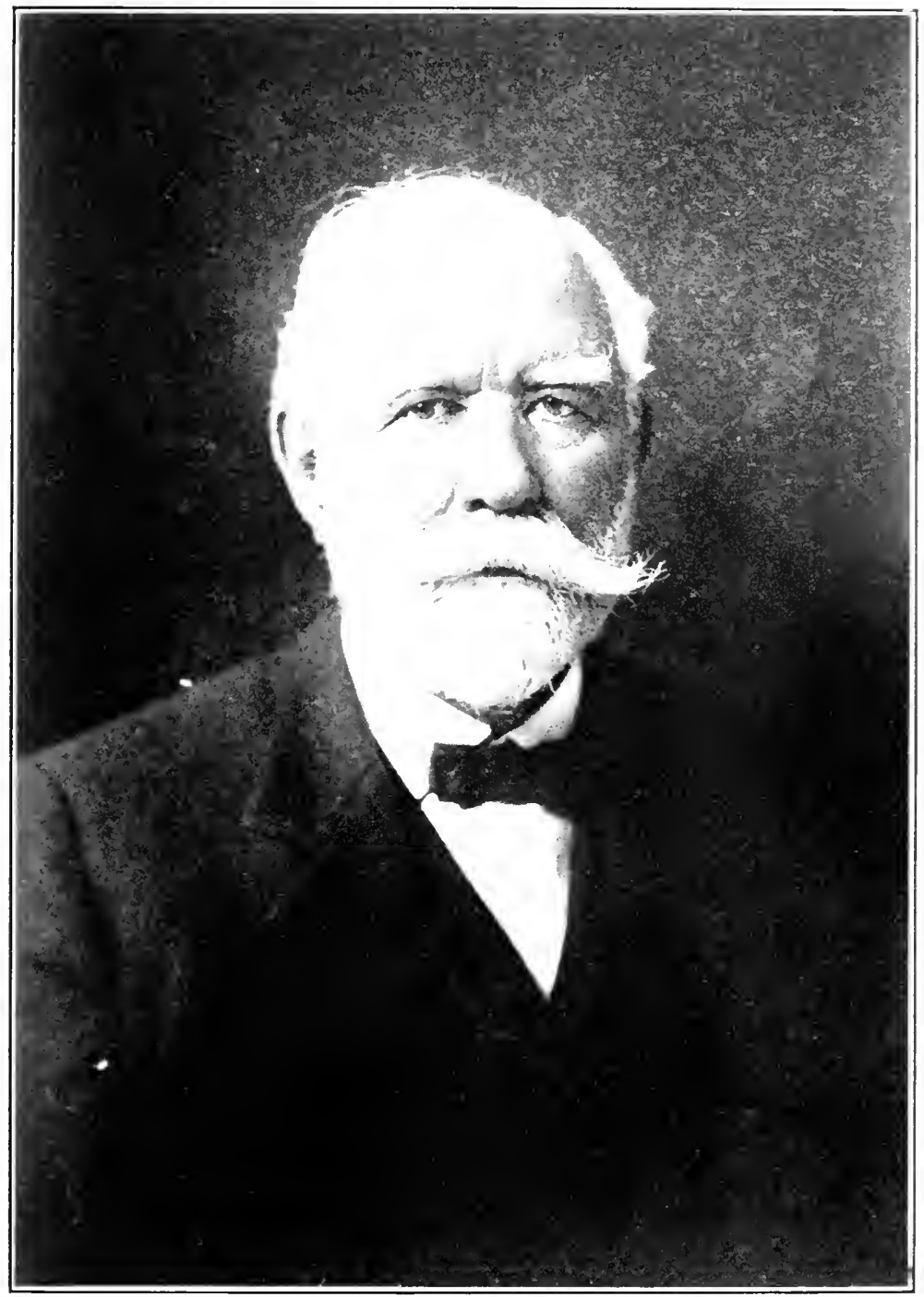

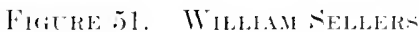


cult to verify; and third, the high cost of making cutting tools which would conform accurately to the standard. He proposed the sixty degree angle as easier to make and already in general use in this country, and the flat top as easy to generate and to verify. He went a step further, and proposed at the same time a standard for bolt-heads and nuts, in which the dimensions were derived from a simple formula and the distance across flats was the same for square and hexagon nuts, so that the same wrench would do for either style of nut.

This paper had as great influence in America as Whitworth's paper of 1841 had in England. A committee was appointed to investigate the question and recommend a standard. On this committee, among others, were William B. Bement, C. T. Parry of the Baldwin Locomotive Works, S. V. Merrick, J. H. Towne, and Coleman Sellers. Early in the next year the committee reported in favor of the Sellers standard, the Franklin Institute communicated their findings to other societies, and recommended the general adoption of the system throughout the country. The Sellers' thread was adopted by the United States Government for all government work in 1868 , by the Pennsylvania Railroad in 1869, the Master Car Builders' Association in 1872, and soon became practically universal. After exhaustive investigation the Sellers' form of thread was adopted in 1898 by the International Congress for the standardization of screw threads, at Zurich, and is now in general use on the continent of Europe. ${ }^{10}$

In 1868 William Sellers organized the Edgemoor Iron

10 For the discussion of the Sellers' screw thread and the circumstances surrounding its adoption, see: Journal of the Franklin Institute, Vol. LXXVII, p. 344; Vol. LXXIX, pp. 53, 111; Vol. CXXIII, p. 261; Vol. CXXV, p. 185. 
Company which furnished the iron work for the principal Centennial buildings and all the structural work of the Brooklyn Bridge. In the development of this business, he led the way in the distinctly American methods and machinery by which the building of bridges has been, to a great extent, put upon a manufacturing basis. This involved the design and introduction of hydraulic machinery, large multiple punches, riveters, cranes, boring machines, etc.

The excellence of his machinery soon brought him into contact with government engineers and throughout his life his influence in the War and Navy Departments was great. In 1890 the Navy Department called for bids on an eight-foot lathe, with a total length of over 128 feet, to bore and turn sixteen-inch cannon for the Naval Gun Factory at Washington. Sellers disapproved of the design and refused to bid on it. He proposed an alternative one of his own, argued its merits in person before the Board of Engineers, and secured its adoption and a contract for it. This great lathe, weighing over 500,000 pounds, has attracted the attention of engineers from all parts of the world. In $1873 \mathrm{Mr}$. Sellers reorganized the William Butcher Steel Works as the Midvale Steel Company and became its president. Under his management the company grew rapidly, and later became a leader in production of heavy ordnance.

It was here that Frederick W. Taylor began in 1880 his work on the art of cutting metals, which resulted in modern high-speed tool steels and a general re-design of machine tools. These experiments, covering a period of twenty-six years, cost upwards of $\$ 200,000$. Mr. Taylor has frequently acknowledged his indebtedness in this work to the patience and courage of Mr. Sellers, who was then an old man and might have been expected to oppose radical change. It was he who made the work 
possible, however, and he supported Taylor unwaveringly in the face of constant protests. ${ }^{11}$ Mr. Sellers was a man of commanding presence, direct but gracious in manner, who won and held the respect and loyalty of all about him. His judgment was almost unerring and he dominated each of the great establishments he built up. The firm of William Sellers \& Company had another master mind in that of Dr. Coleman Sellers, a second cousin of William Sellers. ${ }^{12}$ He was born in Philadelphia in 1827, his father, Coleman Sellers, being also an inventor and mechanic. Like Nasmyth he spent his school holidays in his father's shop, which was at Cardington. In 1846, when he was nineteen years old, he went to Cincinnati and worked in the Globe Rolling Mill, operated by his elder brothers, where the first locomotives for the Panama Railroad were built; and in two years he became superintendent. In 1851 he became foreman of the works of James and Jonathan Niles, who were then in Cincinnati and building locomotives. Six years later he returned to Philadelphia, became chief engineer of William Sellers \& Company, and remained with them for over thirty years, becoming a partner in 1873. During these years he designed a wide range of machinery, which naturally covered much the same field as that of William Sellers, but his familiarity with iocomotive work especially fitted him for the design of railway tools. His designs were original, correct and refined. The Sellers coupling was his invention and he did much to introduce the modern systems of power transmission.

Doctor Sellers was a good physicist, an expert pho-

11 F. W. Taylor: Paper on the "Art of Cutting Metals," Trans. A. S. M. E., Vol. XXVIII, p. 34.

12 See Trans. A. S. M. E., Vol. XXIX, p. 1163; Cassier's Magazine, August, 1903, p. 352 ; Journal of the Franklin Institute, Vol. CXLIX, p. 5. 
tographer, telegrapher, microscopist, and a professor in the Franklin Institute, his lectures always drawing large audiences. Like William Sellers, he was a member of most of the great engineering and scientific societies, here and abroad; and he was president of the American Society of Mechanical Engineers, of which he was a charter member. He was received with the greatest distinction in his visits to Europe. In 1886 impaired health compelled his relinquishing regular work and he resigned his position of engineer for William Sellers \& Company, being succeeded by his son, the present president of the company. His last great work was in connection with the power development of Niagara Falls. $\mathrm{He}$ was engineer for the Cataract Construction Company and served on the commission which determined the types of turbines and generators and the methods of power transmission finally adopted. Among the others on this commission were Lord Kelvin, Colonel Turretini, the great Swiss engineer, and Professor Unwin, and its report forms the foundation of modern large hydro-electric work. William Sellers \& Company has a unique distinction among the builders of machine tools in laving had the leadership of two such men as William and Coleman Sellers.

William B. Bement, the son of a Connecticut farmer and blacksmith, was born at Bradford, N. H., in 1817. His education was obtained in the district schools and in his father's blacksmith shop. His mechanical aptitude was so clear that he was apprenticed to Moore \& Colby, manufacturers of woolen and cotton machinery at Peterboro, N. H. His progress at first was rapid. Within two years he became foreman, and on the withdrawal of one of the partners, was admitted into the firm. He continued there three years, already giving much thought to machine tools, for which he saw the 

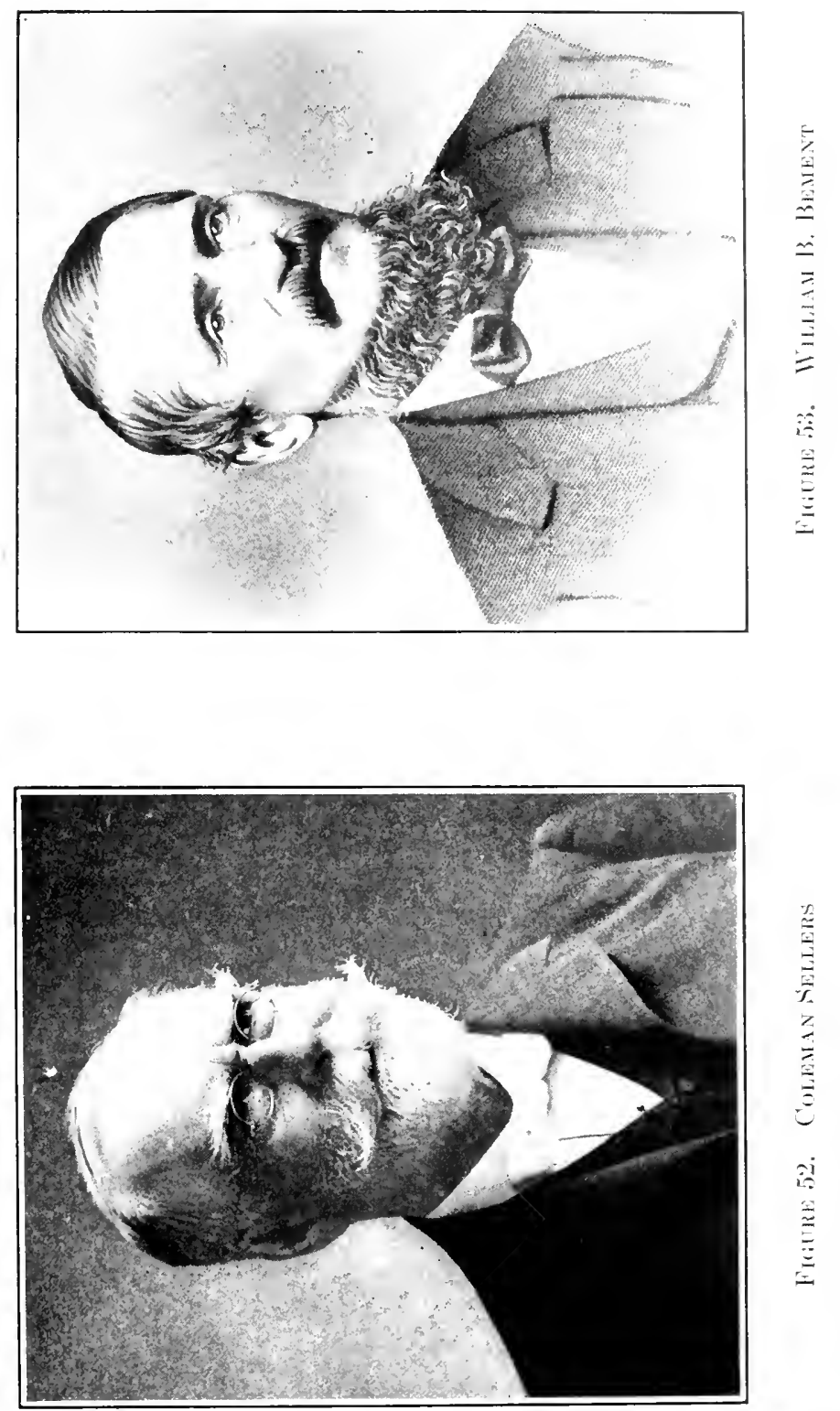

资 
rising need. In 1840 he went to Manchester and entered the Amoskeag shop when it was just finished, remaining there two years as a foreman and contractor under William A. Burke, to whom we have referred elsewhere. From there Bement went to take charge of a shop for manufacturing woolen machinery at Mishawaka, Ind. Unfortunately it was burned to the ground while Bement had gone back to New Hampshire for his family, so that when he returned with them he found himself without employment and with only ten dollars in hand. For the time being he worked as a blacksmith and gunsmith, and made an engine lathe for himself in the shop of the St. Joseph Iron Company, which gave him permission to use their tools in return for the use of his patterns to make a similar machine for themselves. Much of the work in making this lathe was done by hand as there was no planer within many hundred miles. The St. Joseph Iron Company, seeing his work, offered him the charge of their shop, to which he agreed, provided the plant were enlarged and equipped with proper tools. This was done, but just as everything was completed this plant also was burned down. Bement had plans for another shop ready the following day, went into the woods with others, cut the necessary timber, and a new shop was soon completed. He remained there for three years, constructing a variety of machine tools, one of which was a gear cutter said to have been the first one built in the West, or used beyond Cleveland.

He returned to New England as a contractor in the Lowell Machine Shop under Burke, who had gone there from the Amoskeag Mills in 1845. On account of Bement's resourcefulness and skill in designing, Burke induced him to relinquish his contracts and take charge of their designing, which he did for three years, his residence at Lowell covering in all about six years. 
In 1851 Elijah D. Marshall, who had established a business of engraving rolls for printing calicos in 1848 and had a small shop at Twentieth and Callowhill Streets in Philadelphia, offered Bement a partnership. He moved to Philadelphia in September of that year, and with Marshall and Gilbert A. Colby, a nephew, he began the manufacture of machine tools under the name of Marshall, Bement \& Colby, thus starting only a year or so after Sellers. Marshall was a large man, dignified and deliberate in speech. Bement was strong, vigorous, a born designer, a remarkably rapid draftsman, and had a capacity for work rarely equalled. Colby was also a man of considerable mechanical ability, with advanced business ideas. Their shop consisted of a single three-storied, stone, whitewashed building, $40 \mathrm{by}$ 90 feet. Their entire machine shop was on the first floor, with a 10- by 12-foot room for an office. The engine, boiler and blacksmith shop were in small outbuildings. Part of the second floor was rented to another factory and the rest was sometimes used for religious meetings, while the third floor was used for engraving printing rolls. Their tools were few and crude; among them were a 36 -inch lathe with a wooden bed and iron straps for ways, and a 48-inch by 14-foot planer with ornate Doric uprights. Marshall and Colby soon retired, the latter going to Niles, Mich., where he was very successful. James Dougherty, an expert foundryman, and George C. Thomas entered the firm, which became Bement \& Dougherty, the plant being known as the "Industrial Works." Mr. Thomas contributed considerable capital, and a new shop and a foundry were built. At the same time they installed a planer 10 feet wide by 8 feet high, to plane work 45 feet long, a notable tool for that day.

After a few years of struggle, the plant began to grow 
rapidly and at one time was the largest of its kind in the country. Bement and Sellers were among the first to concentrate wholly on tool building. They confined themselves to work of the highest quality. Both made much heavier tools, as we have said, than the New England builders their only competitors, and in a short time had established great reputations. Bement relied little on patent protection, trusting to quality and constant improvement. Thomas retired from the partnership in 1856 and Dougherty in 1870; and Clarence S. Bement joined the firm, which became William B. Bement \& Son. John M. Shrigley became a partner in 1875, William P. Bement in 1879, and Frank Bement in 1888.

Frederick B. Miles was an employee of Bement \& Dougherty who established a tool business under the name of Ferris \& Miles, which afterward became the Machine Tool Works. While head of these works, Miles greatly improved the steam hammer, particularly its valve mechanism, and many details of what is known as the Bement hammer were invented by Miles. In 1885 the Machine Tool Works consolidated with William Bement \& Son, forming Bement, Miles \& Company. Mr. Miles was an accomplished engineer and designer, with the unusual equipment of six languages at his command, an asset of value in the firm's foreign business. William Bement, Senior, died in 1897, and in 1900 the business became a part of the Niles-Bement-Pond Company. Mr. Miles retired at that time and has not since been active in the tool business. ${ }^{13}$

Although Bement and Sellers contributed more to the art of tool building than any of the other Philadelphia

13 Most of the foregoing details in regard to the Bement \& Miles Works have been obtained from Mr. Clarence S. Bement and Mr. W. T. Hagman, their present general manager. 
mechanics, some of these others ought to be mentioned. Matthias W. Baldwin, a native of New Jersey, began as a jeweler's apprentice. In partnership with David H. Mason he began making bookbinders' tools, to which he added in 1822 the engraving of rolls for printing cotton goods and later of bank notes. From the invention and manufacture of a variety of tools used in that business they were led gradually into the machine tool business, the building of hydraulic presses, calender rolls, steam engines, and finally locomotives. In 1830 Baldwin built a model locomotive for the Peale Museum which led to an order from the Philadelphia \& Germantown Railroad for an engine which was completed in 1832 and placed on the road in January, 1833. An advertisement of that time says: "The locomotive engine built by Mr. M. W. Baldwin of this city will depart daily, when the weather is fair, with a train of passenger cars. On rainy days horses will be attached in the place of the locomotive."

From this beginning has sprung the Baldwin Locomotive Works, which employs approximately 20,000 men. In 1834 they built five locomotives; in 1835 , fourteen; in 1836, forty. Their one thousandth locomotive was built in 1861; the five thousandth in 1880 and the forty thousandth in 1913. These works have naturally greatly influenced the neighboring tool makers. From the beginning, both Bement and Sellers specialized on railway machinery and they have always built a class of tools larger than those manufactured in New England.

The Southwark Foundry was established in 1836, first as a foundry only, but a large machine shop was soon added. The owners were S. V. Merrick, who became the first president of the Pennsylvania Railroad Company, and John Henry Towne, who was the engineering partner. The firm designed and built steam 
engines and other heavy machinery and introduced the steam hammer into the United States under arrangement with James Nasmyth. From the designs of Capt. John Ericsson they built the engines for the "Princeton," the first American man-of-war propelled by a screw, and later were identified with the Porter-Allen steam engine. Mr. Towne withdrew from the firm about 1848, and the firm name became successively Merrick \& Son, Merrick \& Sons, Henry G. Morris, and finally the Southwark Foundry \& Machine Company.

I. P. Morris \& Company came from Levi Morris \& Company, founded in 1828, and for many years were engaged in a similar work. In $1862 \mathrm{Mr}$. J. H. Towne, above referred to, was admitted to the firm as the engineering partner, and the firm name then became I. P. Morris, Towne \& Company, until about 1869 when Mr. Towne withdrew. At his withdrawal the firm name was restored to its original form, I. P. Morris \& Company. It is now a department of the Cramp Ship Building Company. During the Civil War the works were occupied largely in building engines and boilers for government vessels, and blast furnace and sugar mill machinery. During this period Henry R. Towne, son of J. H. Towne, entered the works as an apprentice, served in the drawing room and shops, and finally was placed in charge of the erection at the navy yards of Boston and Kittery of the engines, boilers, etc., built for two of the double-turreted monitors. Returning to Philadelphia, he was made assistant superintendent of the works.

J. H. Towne was a mechanical engineer of eminence in his day, whose work as a designer showed unusual thoroughness and finish. He was a warm friend and admirer of both William and Coleman Sellers, and through his influence, Henry R. Towne was at one time a student apprentice in the shops of William Sellers \& 
Company, acquiring there an experience which had a marked influence on his future work. Both of the firms with which J. H. Towne was connected built machine tools for themselves and for others, especially of the heavier and larger kinds, and thus were among the early tool builders. I. P. Morris \& Company, about 1860, designed and built for their own use what was then the largest vertical boring mill in this country. ${ }^{14}$

It may surprise some to learn that the well-known New England firm, the Yale \& Towne Manufacturing Company in Stamford, Conn., is a descendant of these Philadelphia companies. It was organized in October, 1868, by Linus Yale, Jr., and Henry R. Towne, who were brought together by William Sellers. Mr. Yale died in the following December. This company, under the direction and control of Mr. Towne, has had a wide influence on the lock and hardware industry in this country. While the products of the Yale \& Towne Manufacturing Company have always consisted chiefly of locks and related articles, they have added since 1876 the manufacture of chain blocks, electric hoists, and, during a considerable period, two lines allied to tool building, namely, cranes and testing machines. This company was the pioneer crane builder of this country, organizing a department for this purpose as early as 1878 , and developing a large business in this field, which was sold in 1894 to the Brown Hoisting Machine Company of Cleveland, Ohio. The building of testing machines was undertaken in 1882, to utilize the inventions of Mr. A. H. Emery, and was continued until 1887, when this business was sold to William Sellers \& Company, for the same reason that the crane business was sold; namely, that both were incongruous with the other and principal products of the company.

1\$From correspondence with Mr. Henry R. Towne. 
In recent years the Bilgram Machine Works, under the leadership of Hugo Bilgram, an expert Philadelphia mechanic, has made valuable contributions to the art of accurate gear cutting.

In the cities between New York and Philadelphia, and here and there in the smaller towns of Pennsylvania, are several tool builders of influence. Gould \& Eberhardt in Newark is one of the oldest firms in the business, having been established in 1833. Ezra Gould, its founder, learned his trade at Paterson, and started in for himself at Newark in a single room, 16 feet square. Within a few years the Gould Machine Company was organized, the business moved to its present loeation, and a line of lathes, planers and drill presses was manufactured. To these they added fire engines. Ulrieh Eberhardt started as an apprentice in 1858 and became a partner in 1877 , the firm name becoming E. Gould \& Eberhardt, and later Gould \& Eberhardt. Mr. Gould retired in 1891, and died in 1901. Mr. Eberhardt also died in 1901; the business has since been incorporated and is now under the management of his three sons. They employ about 400 men in the manufacture of gear and rack eutting machinery and shapers.

The Pond Machine Tool Company, which moved from Worcester to Plainfield, N. J., in 1888, was founded by Lucius W. Pond. ${ }^{15}$ It is a large and influential shop and one of the four plants of the Niles-Bement-Pond Company. Their output is chiefly planers, boring mills and large lathes.

The Landis Tool Company, of Waynesboro, Pa., builders of grinding machinery, springs from the firm of Landis Brothers, established in 1890 by F. F. and A. B. Landis. One was superintendent and the other a tool maker in a small plant building portable engines and 15 See p. 222. 


\section{ENGLISH AND AMERICAN TOOL BUILDERS}

agricultural machinery. A small Brown \& Sharpe grinding machine was purchased for use in these works. Mr. A. B. Landis became interested in the design of a machine more suited to their particular work, and from this has developed the Landis grinder. 


\section{CHAPTER XX}

\section{THE WESTERN TOOL BUILDERS}

Prior to 1880 practically all of the tool building in the United States was done east of the Alleghenies. The few tools built here and there in Ohio and Indiana were mostly copies of eastern ones and their quality was not high. In fact, there were few shops in the West equipped to do accurate work. "Chordal's Letters," published first in the American Machinist and later in book form, ${ }^{1}$ give an excellent picture of the western machine shop in the transition stage from pioneer conditions to those of the present day.

Good tool building appeared in Ohio in the early eighties, and within ten years its competition was felt by the eastern tool builders. The first western centers were Cleveland, Cincinnati and Hamilton. Of these, Cleveland seems to have been the first to build tools of the highest grade.

We have already noted that the Pratt \& Whitney shop in Hartford furnished Cleveland with a number of its foremost tool builders. The oldest of these and perhaps the best known is the Warner \& Swasey Company. This company has the distinction, shared with only one other, of having furnished two presidents of the American Society of Mechanical Engineers. Oddly enough the other company is also a Cleveland firm, the Well-

1 Henry W. See: "Extracts from Chordal's Letters"; McGraw-Hill Book Co., N. Y. 12th Edition. 1909. 
man, Seaver, Morgan Company, builders of coal- and ore-handling machinery, and of steel mill equipment.

Worcester R. Warner, of the Warner \& Swasey Company, was born at Cummington, Mass., in 1846. Although a farmer's son and denied a college education, he had access in his own home to an admirable library, which he used to great advantage. When nineteen years old he went to Boston and learned mechanical drawing in the office of George B. Brayton. Shortly afterwards he was transferred to the shop at Exeter, N. H., where he first met Ambrose Swasey. Mr. Swasey was born at Exeter, also in 1846, went to the traditional "little red schoolhouse," and learned his trade as a machinist in the shop to which Warner came. In 1870 they went together to Hartford, entered the Pratt \& Whitney shop as journeymen mechanics, and in a short time had become foremen and contractors. Mr. Swasey soon gained a reputation for accurate workmanship and rare ability in the solution of complex mechanical problems. He had charge of the gear department, and invented and developed a new process of generating spur gear teeth, which was given in a paper before the American Society of Mechanical Engineers. ${ }^{2}$ Mr. Warner, also, became one of the company's most trusted mechanics, was head of the planing department, and had charge of the Pratt \& Whitney exhibit at the Centennial Exposition in Philadelphia.

In 1881 they left Hartford and went first to Chicago, intending to build engine lathes, each putting $\$ 5000$ into the venture; but finding difficulty in obtaining good workmen there, they moved in about a year to Cleveland, where they have remained. Their first order was for twelve turret lathes, and they have built this type of machine ever since. At various times they have built

2 Trans. A. S. M. E., Vol. XII, p. 265. 

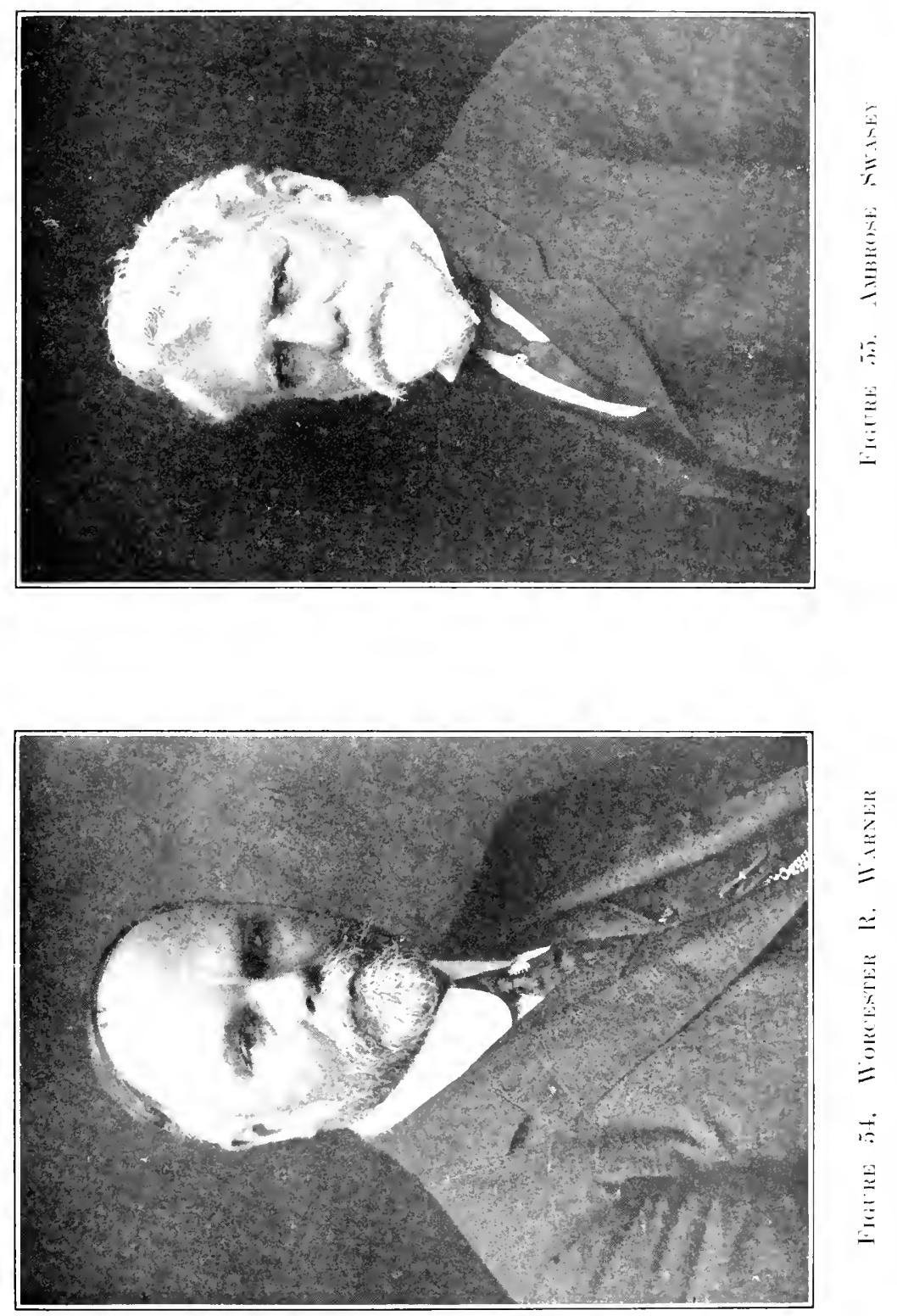
speed lathes, die-sinking machines, horizontal boring mills, and hand gear-cutters, but they now confine their tool building to hand-operated turret lathes. They have never built automatics.

The building of astronomical instruments was not in their original scheme, but Mr. Warner's taste for astronomy and Mr. Swasey's skill in intricate and delicate mechanical problems, led them to take up this work. These instruments, usually designed by astronomers and instrument makers, were in general much too light; at least the large ones were. From their long experience as tool builders, Warner and Swasey realized that strength and rigidity are quite as essential as accuracy of workmanship where great precision is required. The design of a large telescope carrying a lens weighing over 500 pounds at the end of a steel tube forty or sixty feet long, and weighing five or six tons, which must be practically free from flexure and vibration and under intricate and accurate control, becomes distinetly an engineering problem. To this problem both Mr. Warner and Mr. Swasey brought engineering skill and experience of the highest order.

When the trustees of the Lick Observatory called in 1886 for designs for the great 36 -inch telescope, Warner \& Swasey submitted one which provided for much heavier mountings than had ever been used before, and heavier construction throughout. They were awarded the contract and the instrument was built and installed under Mr. Swasey's personal supervision. It is located on the very top of Mount Hamilton in California, 4200 feet above sea-level; and to give room for the observatory 42,000 tons of rock had to be removed. The great instrument, weighing with its mountings more than forty tons, "was transported in sections, over a newly made mountain road, sometimes in a driving snowstorm, 


\section{ENGLISH AND AMERICAN TOOL BUILDERS}

with the wind blowing from sixty to eighty miles an hour.",

As is well known, the instrument was a brilliant success. The Warner \& Swasey Company has since designed and built the mountings for the United States Naval Observatory telescope, the 40-inch Yerkes telescope, the 72-inch reflecting telescope for the Canadian Government, and the 60-inch reflecting telescope for the National Observatory at Cordoba, Argentina, the largest in use in the southern hemisphere. In addition to this large work, the firm has built meridian circles, transits and other instruments for astronomical work, range finders for the United States Government, and introduced the prismatic binocular into this country.

In connection with this astronomical work Mr. Swasey designed and built a dividing engine capable of dividing circles of 40 inches in diameter with an error of less than one second of arc. A second of arc subtends about one-third of an inch at the distance of one mile. Although the graduations on the inlaid silver band of this machine are so fine that they can scarcely be seen with the naked eye, the width of each line is twelve times the maximum error in the automatic graduations which the machine produces.

Although their reputation as telescope builders is international, Warner \& Swasey are, and always have been, primarily tool builders. They were not the first to build tools in the Middle West, but they were the first to turn out work comparable in quality with that of the best shops in the East.

The Warner \& Swasey shop has had the advantage of other good mechanics besides its proprietors. Walter Allen, an expert tool designer, did his entire work with them, rising from apprentice to works manager. Frank

s Cassier's Magazine, March, 1897, p. 403. 
Kempsmith, originally a Brown \& Sharpe man, was at one time their superintendent. Lucas, of the Lucas Machine Tool Company, was a foreman. George Bardons, who served his apprenticeship with Pratt \& Whitney, went west with Warner and Swasey when they started in business and was their superintendent; and John Oliver, a graduate of Worcester Polytechnic, was their chief draftsman. The last two left Warner \& Swasey in 1891 and established the firm of Bardons \& Oliver for building lathes.

Another old Pratt \& Whitney workman is A. W. Foote of the Foote-Burt Company, builders of drilling machines. Unlike the others, however, Foote did not work for Warner \& Swasey.

The first multi-spindle automatic screw machines were manufactured in Cleveland. The Cleveland automatic was developed in the plant of the White Sewing Machine Company for their own work, and its success led to the establishment of a separate company for its manufacture. The Acme automatic was invented by Reinholdt Hakewessel and E. C. Henn in Hartford. Mr. Hakewessel was a Pratt \& Whitney man and Mr. Henn a New Britain boy, who had worked first in Lorain and Cincinnati and then for twelve years in Hartford with Pratt \& Cady, the valve manufactures. In 1895 Henn and Hakewessel began manufacturing bicycle parts in a little Hartford attic, developing for this work a five-spindle automatic. Seven years later the business was moved to Cleveland, where it became the NationalAcme Manufacturing Company, organized by E. C. and A. W. Henn and W. D. B. Alexander, who came from the Union Steel Screw Works. Their business of manufacturing automatic screw machinery and screw machine products has grown rapidly and is now one of the largest industries in Cleveland. 
The White Sewing Machine Company and the Union Steel Screw Works were among the first in Cleveland to use accurate methods and to produce interchangeable work. It was at the Union Steel Screw Works that James Hartness, of the Jones \& Lamson Machine Company, got his first training in accurate work. Their shop practice was good and was due to Jason A. Bidwell, who came from the American Tool Company of Providence.

The Standard Tool Company is an offspring of Bingham \& Company, Cleveland, and of the Morse Twist Drill Company of New Bedford, Mass. From the Standard Tool Company has come the Whitman-Barnes Company of Akron, and from that the Michigan Twist Drill and Machine Company.

Newton \& Cox was established in 1876, and built planers and milling machines. Mr. Newton sold his share in the business to F. F. Prentiss in 1880, went to Philadelphia, and started the Newton Machine Tool Works. Cox \& Prentiss later became the Cleveland Twist Drill Company. They drifted into the drill business through not being able to buy such drills as they required. They began making drills first for themselves, then for their friends, and gradually took up their manufacture, giving up the business in machine tools.

Cincinnati is said to have upwards of 15,000 men engaged in the tool building industry, and to be the largest tool building center in the world. There are approximately forty firms there engaged in this work, many of them large and widely known.

This development, which has taken place within the past thirty-five years, may possibly have sprung indirectly from the old river traffic. Seventy years ago this traffic was large, and Cincinnati did the greater part of the engine and boat building and repair work. When 
the river trade vanished, the mechanics engaged in this work were compelled to turn their attention to something else, and there may be some significance in the coincidence of the rise of tool building with the decline of the older industry.

There had been more or less manufacturing in Cincinnati for many years, but little of it could be described as tool building. Miles Greenwood established the Eagle Iron Works in 1832 on the site now occupied by the Ohio Mechanics Institute. It comprised a general machine shop, an iron foundry, brass foundries, and a hardware factory which rivaled those of New England, employing in all over 500 men. The hardware factory was important enough to attract the special attention of the English commissioners who visited this country in 1853.

In the fifties and early sixties, Niles \& Company built steamboat and stationary engines, locomotives and sugar machinery, and employed from 200 to 300 men. This company was the forerunner of the present Niles Tool Works in Hamilton. Lane \& Bodley were building woodworking machinery about the same time, and J. A. Fay \& Company, another firm building woodworking machinery, which started in Keene, N. H., began work in Cincinnati in the early sixties.

The iirst builder of metal-working tools in Cincinnati was John Steptoe; in fact, he is said to have been for many years the only tool builder west of the Alleghenies. Steptoe came to this country from Oldham, England, some time in the forties. It is said that he was a foundling and that his name came from his having been left on a doorstep. He was married before he came to Cincinnati, and had served an apprenticeship of seven years, although he was so young in appearance that no one would believe it. After working some time 
for Greenwood, he started in business for himself, making a foot power mortising machine and later a line of woodworking tools. The first metal-working tool which he built was a copy of the Putnam lathe. With Thomas McFarlan, another Englishman, he formed the firm of Steptoe \& McFarlan, and his shop, called the Western Machine Works, employed by 1870 about 300 men. Their old payrolls contain the names of William E. Gang of the William E. Gang Company; Mr. Oesterlien of the Oesterlien Machine Company; and Mr. Dietz of the old Dietz, Schumacher \& Boye Company, now the Boye \& Emmes Machine Tool Company.

Steptoe was not an originator or an inventor. $\mathrm{He}$ was a rough man, plain spoken, honest and well informed. He died in 1888 at about eighty-four years of age. Thomas P. Egan of the J. A. Fay \& Egan Company, who had worked for Steptoe and was the administrator of his estate, sold the business for the widow to Otting \& Lauder." In compliance with Steptoe's wish it was stipulated that his name should be retained and it has been perpetuated in the various changes through which the business has gone. Today the John Steptoe Company manufactures shapers and milling machines. Steptoe's name should be remembered, for Cincinnati tool building owes its start more to him than to anyone else, with the possible exception of William Lodge, who was himself one of Steptoe's workmen.

Mr. Lodge, the son of George Lodge, a skilled mechanic in the textile industry, was born in Leeds, England, in 1848. After serving his apprenticeship in the shops of Fairbairn \& Company, Leeds, he came to Philadelphia, where he worked for Chambers Brothers from 1869 to 1872, making paper-folding machinery. He came to Cincinnati in 1872 and worked for Steptoe for

4 The above facts are given by several of Steptoe's old workmen. 
eight years, first as a journeyman machinist and later as a foreman. Having saved $\$ 1000$, he formed a partnership with William Barker and they started in business the first day of January, 1880, at Fifth Street and the C. H. \& D. tracks. Associated with them for a short time was Mr. Bechle, another Steptoe workman. Their first task was to true up a few secondhand machines which they had bought for their shop, after which they went out, secured some business, and came back and executed it themselves, since they had no one in their employ. Part of this first business was making some opening dies for Powell and a small turret lathe for Lunkenheimer. Lunkenheimer immediately ordered three more and during the following year eighteen lathes were made and sold. Beginning with $\$ 1000$, the business inventoried at the end of the first year $\$ 7000$; at the end of the second year $\$ 32,000$; and at the end of ten years $\$ 400,000$. Fifteen months after starting they employed seventy-five men. There is little doubt that this rapid success induced quite a number of the better and more ambitious mechanics in Cincinnati to take up similar work. Mr. Lodge was well known among the mechanics of the city and had been president of their union. If one of their own number could build up a successful business, why could they not do the same? Some of the best known of the Cincinnati tool building firms were established during the few years after Mr. Lodge's start.

In $1886 \mathrm{Mr}$. Barker sold his interest to Charles Davis and began making Fox lathes and monitors independently. Lodge and Davis continued in partnership until 1892, when Mr. Lodge sold his interest to Mr. Thomas P. Egan and the firm became Davis \& Egan, and later the American Tool Works. Mr. Lodge, meanwhile, organized the Ohio Machine Tool Company and a year 
later became associated with Murray Shipley, forming the present Lodge \& Shipley Machine Tool Company.

Mr. Lodge's first export order was received in 1889. Alfred Herbert, who had just started in Coventry, sent an inquiry in regard to drill presses to Cincinnati, which was forwarded to Mr. Lodge in London. Mr. Lodge went down to see him and asked whether the inquiry was for purposes of information or for purchase. Mr. Herbert said that if Lodge had a better machine he would buy. Mr. Lodge asked to see his machine and after a little hesitation he was taken out into the shop. The first machine he saw was a planer. He said that he could save 30 per cent on the work as it was being done, and would sell them a machine which would do it for $£ 100$. He was told that the planer they were looking at cost only $£ 65$ and replied that that was all it was worth. He spent several hours in the shop, and left the plant not only with an order, but with the check in payment thereof. This was the beginning of a large export business.

While the firm was Lodge \& Davis, it built lathes, planers and drill presses. Mr. Lodge wanted to manufacture rather than build, and to specialize upon lathes. Mr. Davis, who was a business man, wanted a complete line of tools, as he saw the opportunities of selling other machines with the lathes. This led to a policy, the effect of which was to build up a number of small tool building enterprises, independent of each other, but not competing. About 1887 Lodge \& Davis began concentrating their manufacturing upon engine lathes, and placing orders for other types of tools with mechanics known to them who were just starting up, or with workmen or foremen from their own plant whom they helped to start in business. For instance, to Smith \& Mills, who had been foremen with Steptoe and had started making 
set screws and cap screws, they gave an order for 300 shapers. Another firm, Smith \& Silk, also built shapers for Lodge \& Davis. Later they added planers, and in the early nineties they moved to Kenton, Ohio, and began building shapers and planers for their own account. To R. K. LeBlond, who had served his apprenticeship with Brown \& Sharpe and had come to Cincinnati to make printers' machinery and supplies, Lodge \& Davis gave a large order for slide-rests. To William Owen, one of their workmen, they gave an order for Fox monitors. Owen went into partnership with Philip Montanus and started the Springfield Machine Tool Company, and Lodge \& Shipley bought their entire product for eight years. Through Mr. Lodge's influence, Frank Kempsmith came from Warner \& Swasey as one of the partners in this firm. He afterwards moved to Milwaukee and started the Kempsmith Manufacturing Company. This policy on the part of Lodge \& Davis unquestionably set upon their feet a number of small companies which have since grown into successful, independent enterprises.

William E. Gang worked for Lodge as vice-foreman. Greaves was his planer foreman; Henry Dreses was his chief draftsman; and William Herman, of the Fosdick Machine Tool Company, was his superintendent. Gang \& Dietz, and Fosdick \& Plucker also began by doing work for Lodge \& Davis. Through various changes the former has become the present Boye \& Emmes Machine Tool Company and the latter the Fosdick Machine Tool Company. Dreses, with Oscar Mueller, started Dreses, Mueller \& Company in 1896. In 1902 they separated and each formed a company of his own. Greaves, with H. Klussman, began building woodworking machinery about 1890 , to which they have since added the building of engine lathes. The Cincinnati 
Planer Company is another offshoot of Lodge \& Davis and Davis \& Egan through B. Quillen and W. Burtner, who were in their office.

It is impossible here to give the history of all the Cincinnati tool builders and only a few can be mentioned. Henry Bickford, a native of New Hampshire and an employee of J. A. Fay \& Company, started a few years before Mr. Lodge. In 1874 he began building five sizes of upright drills, from 20 to 38 inches in capacity. While his growth was not so rapid as $\mathrm{Mr}$. Lodge's, it was steady and by 1885 he had built 3000 machines. The first machines were cheap and built for competition, but from them has developed a product of the highest quality. The Bickford Drill Company was organized in 1887 and the business was extended to include radial and universal drills. The company was reorganized in 1893, and in 1894 it absorbed the Universal Radial Drill Company, its only competitor in this special field in the city. Some years ago the name was changed to the Cincinnati Bickford Tool Company. Mr. Anton Mill and Mr. Henry M. Norris have in the main been responsible for their engineering practice. Mr. Mill was a German who came to them from the Cincinnati Milling Machine Company and Mr. Norris is a Cornell graduate with a wide experience in the eastern tool building shops.

The Cincinnati Milling Machine Company comes from the Cincinnati Screw \& Tap Company, started by Frederick Holtz, who began making screws and taps in a kitchen about 1880 . He made a milling machine with a wooden base for fluting his taps, because he was too poor to buy one. Lunkenheimer saw this machine and ordered one, and from this start came their present milling machine business. The firm became the Cincinnati Milling Machine Company in 1889 with Mr. Frederick A. 
Geier as president. Mr. A. L. DeLeeuw was for a number of years engineer for this company and his experiments in cutting tools have had a wide influence on all milling machine practice.

The prominence of Hamilton, Ohio, in tool building is due chiefly to the Niles Tool Works, which moved thither from Cincimnati about 1876. Before the war the old firm, Niles \& Company, to which we have already referred, occasionally built tools for their own use. After the war, George Gray, who was their designer and superintendent, was sent through the eastern states to familiarize himself with machine tool building and the company took it up as part of their regular work. After their removal to Hamilton, they confined themselves wholly to this work and have grown to be one of the largest firms in the country in this field. About 1900 the Niles Tool Works were brought under the same management as Bement, Miles \& Company of Philadelphia, the Pond Machine Tool Company of Plainfield, N. J., and the Pratt \& Whitney Company of Hartford, and they are now operated as one of the plants of the Niles-Bement-Pond Company.

In 1880 Gray left the Niles Tool Works and started the Universal Radial Drill Company in Cincinnati. This company built the first round column radial drills, plain and universal, after Mr. Gray's designs. He left the company in 1883 and about ten years later it ceased business. The G. A. Gray Company, which he started in 1883, at first built lathes, but has specialized on planers and is now one of the foremost firms in the country specializing in this type of tool.

As the demand for machine tools spread westward, tool building has followed it, and an increasing number of companies are springing up in Indiana, Illinois and Wisconsin. The oldest of these, the W. F. \& John 
Barnes Company of Rockford, Ill., began making jig saws in 1872. Six years later they added the building of small lathes. About the same time they made some drill presses for their own use and then began manufacturing them for the trade. Later, tool grinders, arbor presses, radial and gang drills were added successively to their line of machines. Their only competitors were in Worcester and Cincinnati, and the high freight rates at that time gave them an important advantage in the West. Their early machinery, built to meet pioneer conditions, found a considerable market in the less developed foreign countries and they have built up a widespread export business.

Rockford has become a clearly defined center for tool builders. For many years the W. F. \& John Barnes Company was the only one in the city, but in 1888 the Mechanics Machine Company was established. About 1893 the Ingersoll Milling Machine Company moved to Rockford from Cleveland, where Mr. Ingersoll had been associated with Cox \& Prentiss. This company has been the leader in the development of heavy multiple-head milling machines of the planer type. The Barber-Coleman Company began making mechanics' tools and gear cutters about 1896 . The B. F. Barnes Company, now the Rockford Drilling Machine Company, and the Barnes Drill Company were established in 1897, by B. F. Barnes, a brother of W. F. and John Barnes, who had been associated with them for twenty years as superintendent. In addition to these firms there are the Rockford Machine Tool Company, the Rockford Milling Machine Company, the Rockford Lathe \& Tool Company, the Rockford Iron Works and W. F. Lingren \& Company. The first of these companies started in 1897, making shapers and planers. In 1913 it bought out the drill business of the older Mechanics Machine Com- 
pany. It is said that one of the reasons why Rockford has become such a tool building center is that the neighborhood was settled by Swedish immigrants, who have furnished excellent material for the development of skilled mechanics.

The International Machine Tool Company of Indianapolis was established in 1906. This company manufactures the turret lathes developed by Mr. C. L. Libbey, who was for eleven years chief engineer and superintendent of the Bullard Machine Tool Company of Bridgeport; afterwards superintendent of the Pacific Iron Works of the same city, and of the Ludwig-Loewe \& Company, Berlin, Germany; and for four years and a half construction engineer of the Gisholt Machine Company of Madison, Wis. From Madison he went to Indianapolis.

There are a number of tool builders in Chicago, but though a great manufacturing center, Chicago, like New York, has not specialized in tool building as have some of the smaller places. There are perhaps a dozen firms making large and small tools. Of those who build the larger types of tools, Charles H. Besly \& Company, manufacturers of grinding machines, are best known.

Frederick M. Gardner, of Beloit, Wis., who was at one time with this company, was largely responsible for the development of disk grinding machines. Mr. Gardner was born in Ashfield, Mass., and served his apprenticeship with Wiley \& Russell in Greenfield. From there he went to Pratt \& Whitney's, was later placed in charge of the small tool department until, about 1885 , he was transferred to Chicago as their special western representative on the Pratt \& Whitney tools then being sold by Charles H. Besly \& Company. His acquaintance with Mr. Besly led to the formation of a company, of which Mr. Gardner was superintendent, located at 
Beloit because of Mr. Besly's interest in the water power there. This company manufactured taps, dies, clamps and other small tools. The disk grinder was originated about $\mathbf{1 8 9 0}$ for use in the manufacture of their clamps. For a number of years it retained substantially its first form, but with the advent of coarser grades of emery, a more powerful design with various refinements and adjustments was developed. In $1905 \mathrm{Mr}$. Gardner organized a separate company known as the Gardner Machine Company. Since that time still larger and more powerful machines have been designed, lever feeds and micrometer stop screws added, and various types, such as double spindle, vertical spindle and pattern makers' grinders, built. Abrasive ring wheels, interchangeable with disk wheels allow the use of wet grinding and thus extend the field of this type of machine. Mr. F. N. Gardner died in 1913. His sons, who were with him from the origin of the disk grinder, are continuing his work in the Gardner Machine Company.

The Gisholt Machine Works at Madison, which grew out of a plant manufacturing agricultural machinery, has developed a widely used turret machine for chucking work invented by Mr. Comrad N. Conradson. This machine applied the turret principle to much larger work than it had been used for up to that time. Mr. Conradson has left the Gisholt Company and has since designed a powerful, multi-spindle automatic lathe which, like the Bullard machine (shown in Fig. 56), is vertical, and, although a lathe, it has assumed a form which would scarcely be recognized as such. This machine is built by the Giddings \& Lewis Manufacturing Company of Fond du Lac, Wis.

Milwaukee is rapidly establishing a reputation for tool building. Kearney \& Trecker and the Kempsmith Manufacturing Company are well-known builders of 


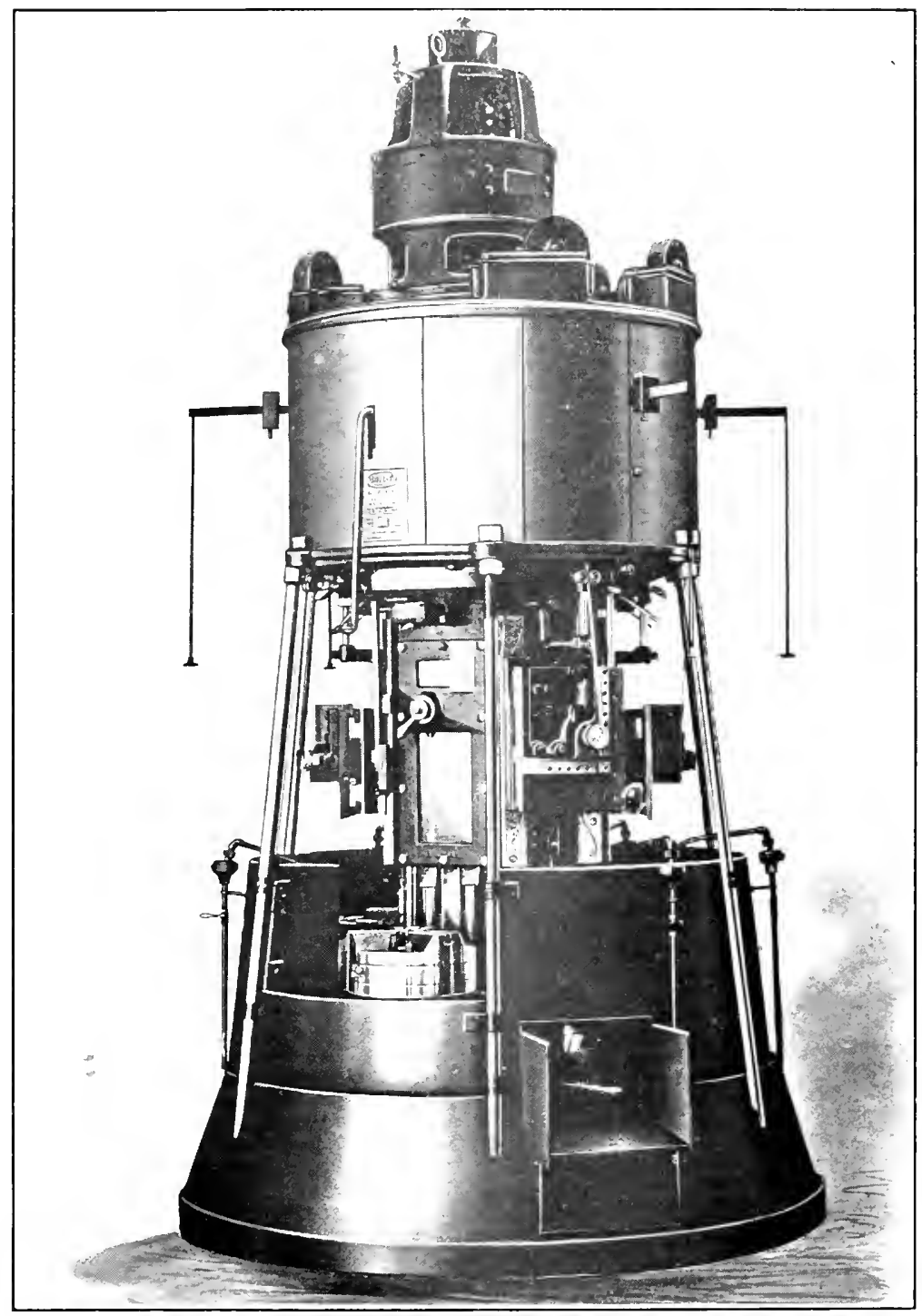

Figure 56. The "Milt-aU-Mhte" Lithe 1914 


\section{.}


milling machines. Mr. Kempsmith, as we have already seen, was a Brown \& Sharpe man, afterwards superintendent of Warner \& Swasey and for sixteen years at Springfield, Ohio, with William Smith and Philip Montanus. Other tool builders such as the Milwaukee Machine Tool Company and the Steinle Turret Machine Company of Madison are helping to spread the art of tool building in this new region.

We have not been able to mention all of the western tool builders. Most of these firms have been established in recent years and are busy building up a market and a reputation. Some of them will take positions of leadership as Warner \& Swasey and Lodge \& Shipley have done, but this of course requires time.

There can be no "conclusion" to the history of a live and growing industry. A few of the present tendencies, however, may be pointed out.

One of the most far-reaching influences ever received by tool building came from the introduction of high speed steel through the work of Frederick W. Taylor and his associates. These steels made possible much heavier cuts, anci increases in cutting speeds, to two or two and one-half times the previous prevailing practice. $\mathrm{Mr}$. Taylor also made a remarkable investigation of the lathe-planer type of cutting tool. A. L. DeLeeuw and others have studied the milling cutter and twist drill and examined the causes of the failure of cutting edges in action, and the influence of large clearances for chips and coolants. The new cutting steels and these investigations have compelled an extensive redesign of machine tools during the past fifteen years, a process which is still going on as new demands are made upon the tool builders.

These years have also witnessed a development of the "station-type" of machine, or one in which there are 
multiple chucks, indexed from station to station, one position being used for putting in and taking out work while a succession of operations is simultaneously going on at the other stations. In general these are high production machines suitable for long runs of standard work. The multi-spindle automatic bar-stock lathe is an example. One of the latest of these stationtype tools is the vertical machine shown in Fig. 56, which performs all the functions of an engine lathe and is in effect five lathes in one machine.

Another development of recent years has been the extension of the grinding process, both for the rapid removal of metal and for precision work. This has been made possible by the introduction of new and more active abrasives.

The map, Fig. 57, gives a bird's-eye view of the distribution of the tool building industry in the United States, and shows that it is located in a rectangle which includes southern New England and that portion of the Atlantic and Middle States lying roughly north of the Potomac and Ohio and east of the Mississippi rivers. The strong tendency toward concentration in certain localities is clearly seen. (Each dot in the map represents a shop.) Of the 570 plants shown, 117 are in Ohio, 98 in Massachusetts, 66 in Connecticut, 60 in Pennsylvania, 57 in New York, 42 in Illinois, 29 in Michigan and 18 in Wisconsin. Thirty years ago practically none would have been found west of Buffalo. Today the majority are there, although most of the more important companies are still in the East. Unquestionably this will equalize itself as the newer western shops develop.

The general types of machine tools seem to be firmly established, and new or startling inventions and revolutionary changes seem unlikely. The present trend is

5 From the American Machinist, January 29, 1914, p. 210. 


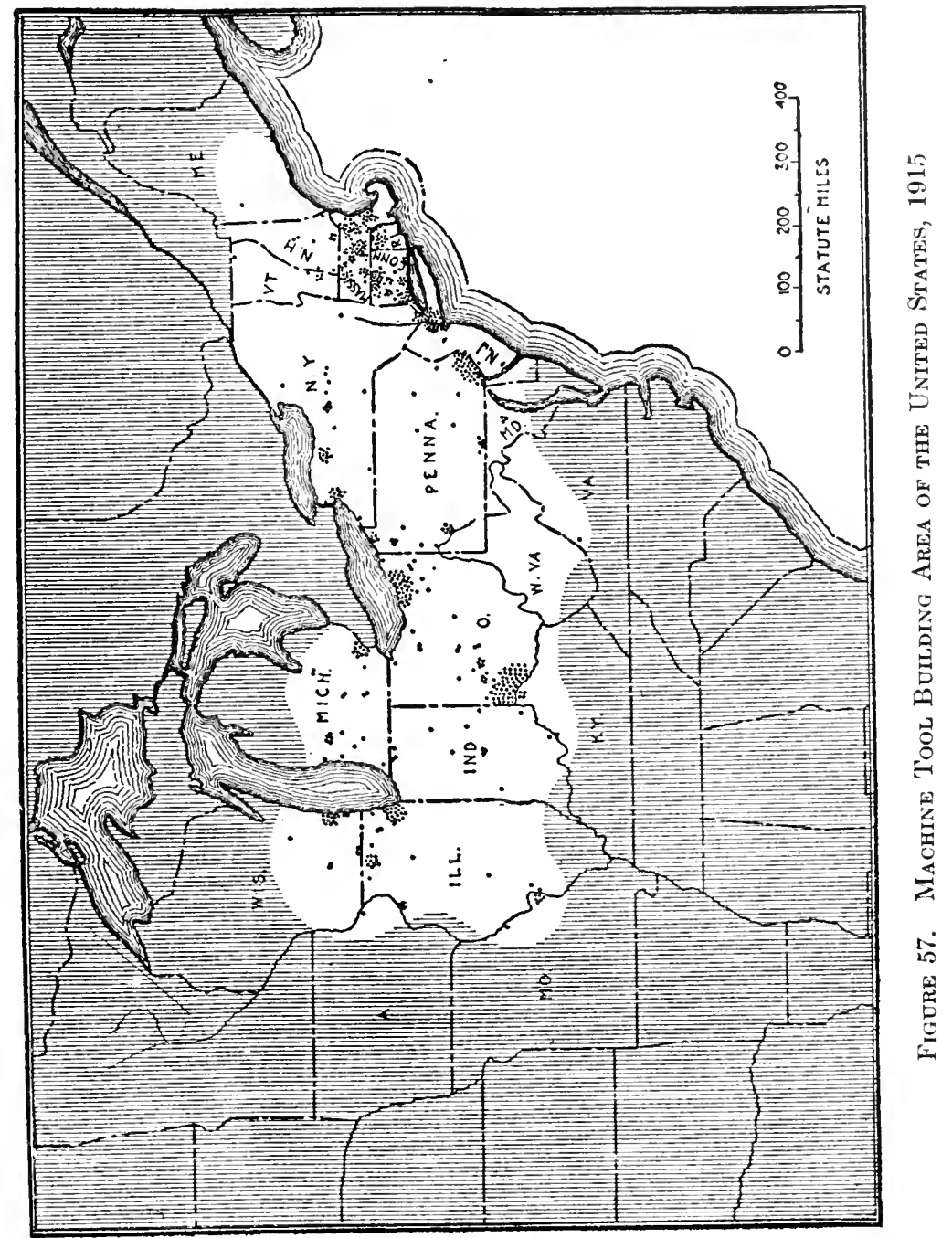




\section{ENGLISH AND AMERICAN TOOL BUILDERS}

toward higher speeds, heavier cuts with the use of great quantities of lubricant, further refinements of jigs and holding devices, and the use of highly developed automatic machines which may be operated by unskilled labor.

The unprecedented demand upon American tool builders made by the European War has vastly increased their facilities, and will probably tend to establish them even more firmly as world leaders in the industry. 
the town of Pamelia. Here they lived about three years, then moved to another small farm in the same town. I spent most of my time helping on these two farms, and breaking steers. Had yokes made for yearlings, had a little sled, and many times in winter drove to Watertown Village to mill with grists. When I was fifteen years old Grandfather and Mother moved to what is now called North Watertown onto a small farm. About this time I began to feel a little uneasy, and wanted to try something else for a living. I went to live with Uncle Judah Lord in Jewellville, North Watertown. Worked for him making Carpenters' and Joiners' Tools. My work for the first year was sawing by hand seasoned beach plank into blocks for planes. This was hard work and I wished myself in some better place (many times). There was nothing in the least to give me courage, but after a while I could make tools very well. What little spending money $I$ had was earned by night work, making packing boxes for a paper-mill nearby. Worked half the night for $25 \phi$. Up to this time I never had but one suit of clothes at the same time, and was doing abont as much work as those that had much more pay. (I only had my board. My folks furnished my clothes.) Lord's business was dull, and I went to work for Orange Woods \& Co. making window sashes. (Will say here that in the basement of Lord's Tool Shop was a Custom Gun Shop. I was always anxious to learn what I could of anything in mechanical line, and spent my spare time with a young man employed in this shop, tinkering on guns, and became quite handy with tools, and could do general repairs quite well. This was the fore-runner of my gun work.) Made sash and doors under contract. All work was done by the best machines, and this gave me a good chance to instruct myself on machines. At the end of one year the shop burnt up, and I was left out in the cold. After a while Wood \& Co. bought out Judah Lord's Tool Shop and commenced tool making. They hired me to work on tools. In about six months this shop burnt up and I was left out in the cold again. At this time I was about seventeen years old, was nearly disheartened and thought I must try some new 
business. Lord had moved to Brownsville and had charge of a Rope Factory and Plaster Mill. He hired me to run the mill 12 hours each day. This was very unpleasant work, terribly dirty. In about one year this mill stopped and I was left in the cold again. Lord moved into a Hotel and hired me to go with him as Bartender, Hostler, etc. When about twenty years old (living with Lord) was drafted out in the service of U. S. to guard the Frontier in the Canada Rebellion of '37-'38. Served three months, was regularly discharged, paid off, and drew my Bounty land (and sold it). Returned to Brownsville and decided to strike out in something new. Being in my 21st year I thought it time to settle on something in a larger field than found in Brownsville. Thought I would start for Vermont. Went to Utica with a friend in york wagon (no railroad then). This friend was taking two children to their Father who was the Engineer (Mr. Hardy) on the Albany \& Schenectady Rail Road, the only road then built that I knew of. This friend was taken sick at Utica and sent me on with the children to Schenectady, which was no small job, as the journey was on the Canal. After seeing the children safe with their Father, I changed my mind and thought I would go west, so boarded a Canal boat and started. On arriving at Utica stept off the Boat and a farmer living ten miles from Utica in the town of Clay, hired me for a month. Worked out my month, and two weeks for another farmer, then I thought it best to visit my friends in Vermont, and took Canal boat for Albany, thence by stage over the Green Mountains to Windsor. I found Windsor Village a dull place. The next morning I started on foot for the west part of the town where my friends all lived. On the road met a man with a team, made enquiry where Mr. Foster Farwell lived, an uncle who married my Father's sister. He looked at me and said, "Get into my wagon and I will take you back to Windsor and then show you one of the best Aunts you ever had. I know you by your looksyour name is Smith Lawrence." He had not seen me before since I was two years old. Found my friends all glad to see 


\section{ENGLISH AND AMERICAN TOOL BUILDERS}

me. Visited with them for several weeks. While with Doct. Story found he had two Rifles, one made by his Brother, Asa Story, who had a gun shop close by. This he called his Turkey Rifle, the other was an old Pennsylvania Rifle, full stock, barrel 4 feet long, all rusty. The Doctor said it had been one of the best. He had killed many a deer with it. I asked him to let me repair the rifle and put on a peep sight. He had heard of this sight but had never seen one. Was very much interested about the sight but did not dare let me repair the Rifle for fear I would spoil it. After a while he consented to let me make the trial and went over with me to his brother's shop and obtained his consent to let me use his shop and tools. I went to work, took the gun all apart, leaded out the barrel, forged out the sight, finished it and put it on the gun. His brother watched me all day. He had never seen a peep sight and a mere boy handling tools and forging out work as I did was a little astonishing to him. On the Doctor's return from his daily trip he made for the shop to see what I had done with his Rifle. He found it in such nice shape that he could not say too much in my praise. He made an appointment for a trial the next day as to the shooting qualities. I had most of the day to give the Rifle a trial and adjust the sights. We went out, he paced off 12 rods from a maple tree which had a $3 / 4$ auger hole in (made for sap spill). He said to fire at that. I found a good rest, lay down on the ground and fired. The Doct. tended target. Could find no ball hole. Said I had missed the tree. I fired again-no ball hole to be found. Doct. came up to me and said I had spoiled his Rifle. Before my repairs he could kill a chicken every time at 12 rods. I said, "Uncle, I am very sorry, but I will make the gun all right before I leave it." $\mathrm{He}$ said he could not consent to my doing anything more to improve the shooting qualities-the sight he liked very much. I said that as the gun was loaded would take one more shot and see if I could not hit the tree. After the third shot I went up to the tree to investigate, and all of the three balls which I had fired were found in the auger hole. The Doct. was astonished-dumb- 
founded. Said he never heard of such shooting. We spent half of the night talking about guns. He said we must go down to Windsor Prison where N. Kendall \& Co. were making guns. They must know about the peep sights. Mine was the first ever seen in that section. We went down to the Prison the next day. The Doct. told them all about the sight and his Rifle. The Company hired me at once for the term of two years at about $\$ 100$. per year and board. My first work was stocking rifles (short stocks, their rifles were stocked only on the breech). The first day I put on five stocks, all hand work. The next morning Mr. Smith, one of the Company, came along and looked the work over. Said the work was done well but it would never do to rush work as I had, for I would soon gunstock them out of town-must hold up a little and take it more easy. After a few days I was put on iron work. I made it a point not to let anything be done in the shop that I did not make myself familiar with, and soon found myself capable of doing the best work. The Co. had quite a number of free men to work on various branches of the work, nice parts, engraving, etc. I found that $I$ was equal to any of them except engraving. Could not at the end of six months do as nice engraving as the older hands, but soon after could compete with any of them. At the end of six months from beginning was put in charge of the shop, much to the dislike of the older hands, but I carried the work along without any trouble, to the satisfaction of all. The foreman of each shop by the rules of the prison acted as turnkey, so I had one section of prisoners to lock up. I worked out my two years engagement. . . . In $1840 \mathrm{I}$ again entered into the employ of N. Kendall \& Co., wages $\$ 1.08$ per day and board. . . . I continued work at the Prison. This was in 1842. During this year the Co. gave up the gun business. I then engaged with the State as foreman in the carriage department, continued in this position for about one and one-half years, then in company with $\mathrm{N}$. Kendall, hired a shop in Windsor Village on Mill River and started the Custom Gun Works and Jobbing. Carried on the business for about one year, done a fair 


\section{6}

business. One day in the winter of 1844 Mr. S. E. Robbins came into the shop and spoke of the Government asking for bids for Rifles. We talked the business over and decided to put in a bid for 10,000 U. S. Rifles. Mr. Robbins, with a friend Price, went on to Washington to put in a bid for the Rifles at $\$ 10.90$ each, appendages extra. This was $10 \phi$ below any other bid. The contract was awarded to Robbins, Kendall \& Lawrence. This was in the time of the Mexican War and the Government was very much in want of Rifles. We made the contract to finish the job in three years. Guns were not made at this day very fast. We had nothing to start with-buildings or capital. We had much opposition from all the Government Gun Contractors. They said we could never do the work. We had nerve and pluck and were determined to carry out the contract. The real work fell upon myself, Robbins not being a mechanic and Kendall not exactly calculated for such nice work, made it hard for me. We went to work with a will-bought land, built factories, bought and made machinery with determined will. We started the business in good shape. Soon after finishing the Rifles, Robbins and myself bought out Kendall. Robbins then said to me, "Lawrence, if it were not for you as a mechanic and by your attention to business we could never go along with the heavy outlay (debts) on our hands." We finished the contract 18 months inside of the time. Made a nice thing out of the job. Went on to Washington. The Ordinance Board (Gen. Talcott) told us that ours was the only Gun Contract ever finished within the contract time. He said, "What do you want now? You have done well and finished." We said, "We want another contract for Rifles." He said, "Come with me over to the Secretary of War's Office" (Sec. Marcy). Gen. Talcott told the Secretary all about our work and wants. The Secretary said they would see about it. On our way back to Gen. Talcott's office he saw that we were a little disappointed. He said, "Go right home and a contract will be sent to you in a few days." The contract came for 15,000 Rifles, which placed us above board. In manufac- 
turing Govt. Rifles a loss of about $38 \%$ was considered for bad material and workmanship. About this time the California Gold excitement was raging. Guns were in great demand. We sold all of our second quality work and good mixt with it, anything to make up the gun for full Govt. price. This was a great relief every way. Things looked very bright. This was in 1849-50. About this time we contracted with Courtland C. Palmer for the manufacture of 5,000 of the Jennings Rifles, now the Winchester (improved). This required new buildings and machinery. We made the guns. Before this date we were very unfortunately situated about freight, as no Rail Road passed through Windsor. Most of our freight came by team from Boston. About this time the Rail Road was built through Windsor, which put us in the market much to our advantage. The Rail Road contractor, Mr. S. F. Belknap, came to us and wanted to start the car business with us, led us to believe that he could control all the Rail Road car work in that section. We went into the business with him. He put in $\$ 20,000$ as a silent partner. We went to a large outlay, and about the time we finished the first cars, Belknap had a quarrel with the President of the Road and we could not sell a ear when we expected to sell. We sold the cars to the Rutland and Burlington Road, took stock and lost every dollar to the tune of $\$ 40,000$. Then we sold $\$ 14,000$ to Boston, Concord \& Montreal Road, lost it all ; $\$ 5,000$ to Sullivan Road, $\$ 75,000$ to Vermont Central. This total loss of $\$ 134,00_{0}$ was a drain on the gun work and cramped us terribly. About this time Belknap died. In settling his estate they brought in a charge of $\$ 105,000$ against Robbins \& Lawrence as money lent. This I knew nothing about. As near as I could learn Belknap \& Robbins lost this money in stocks in Boston. We had to pay the charge, which made a total loss up to this time of $\$ 239,000$, all paid from gun shop business. We gave up the car business after a while. It was a mistake in ever going into this business. While we were finishing the 15,000 Government Rifles and Jennings guns in 1852, we contracted with the Sharps Company for the manu- 
facture of 5,000 Sharpes' carbines in Windsor, and 15,000 Carbines and Rifles in Hartford. Sharps Co. advanced \$40,000 to enable us to build the factories in Hartford. I moved to Hartford in 1853, and after much trouble and many trials started up the works. Want of funds by heavy former losses made it very hard and troublesome work to start the business. After starting the business on the Sharps gun in Hartford, the Minie Rifle contract was taken from Fox Henderson \& Co. for 25,000 Minie Rifles. Before this contract was taken we had the assurance from Dr. Black, Fox Henderson \& Co.'s Agent, that he had in his pocket contracts for 300,000 more as soon as we finished the 25,000. Fox Henderson \& Co. agreed and did advance on the contract $\$ 100,000$. I did not like to enter into this contract for $25,000 \mathrm{only}$, as the outlay for the work would cost more than all the profits twice over. I objected to signing the contract without seeing the large contract in Dr. Black's pocket, and proposed to ask the Doctor to show it. This Mr. Robbins objected to strongly, said it would be an insult to Dr. Black. After a long talk I yielded the point, but told Mr. Robbins that the minute we signed the contract we would be floored. We had better have cut off our right hands. We signed the contract. It proved that Doct. Black had no additional contract. Part of the work was done at Windsor and part in Hartford. For want of funds the whole thing was a total failure. The inspection as far as we went was very severe. With all the gun work on my hands in 1855 and 1856 had a very hard time. The failure of the Robbins \& Lawrence Co. at Windsor brought Robbins \& Lawrence under. A new Company was formed at Windsor. I stept out and engaged with the Sharps Co. on a salary of $\$ 4,000$. About this time Robbins \& Lawrence's Agent, Mr. Robbins' fricnd, failed. I had a notice of his indebtedness to Robbins \& Lawrence of $\$ 43,000$. I went immediately to $\mathrm{Mr}$. Robbins for an explanation. He said that he put this money into Foster's hands to fall back on in case he had any trouble. I said, "You left me out in the cold." Then he said, "You are all right-can demand a large salary any time." This 
was the very money that Sharps Co. had advanced to Robbins \& Lawrence to aid them in starting the Hartford shops. Robbins done all the financing and I attended to the mechanical work-never could find out much about our books. He kept all mostly on memorandum books as I found at last. This $\$ 43,000$ made in all as far as I know of $\$ 282,000$ lost in the business. I had laboured night and day to build up a business and make myself comfortable and well off for old age. All the disappointments were about all that 1 could stand under, but I said to myself that I started out in life with nothing but good health, and would try once more, and try and keep a part of my earnings. While in the employ of Sharps with my salary, patents and speculations on machinery in war time, I found myself as I thought worth over $\$ 100,000$. I went to friends for advice what to invest in. All said, "Put your money into real estate. It never will decrease in Hartford." I took this advice which proved a very disastrous speculation. In 1872, after leaving Sharps \& Co. went into the Street Department, thinking myself well off in this world's goods, but the hard times of 1873 came unexpected, and it took all my salary to furnish my family with a respectable living, and take care of my real estate. It would have been better to let the whole go and pass through bankruptcy as many others did. My pride and the name of my family prevented me from doing this. It was a mistake but cannot now be helped. I have served 18 years as Supt. of Streets in Hartford, 9 years on Water Board, 14 years on Fire Board as Chairman, 4 years on Board of Aldermen, and one year on Council Board, 46 years in all.

\section{Note}

When we first commenced the gun business at Windsor we commenced building nice machinery, made many machines for other gun makers. Made at Windsor for the English Govemment most of their gun machines for the Enfield armory. We ran a regular machine shop also. In Hartford we ran a 
machine shop and Sharps Co. continued the work. In Hartford made most of the machines used in the factory, and many others for the English and Spanish Governments, and other Gun and Sewing Machine Makers. Started the manufacturing of gun machinery in Hartford which brought Pratt and Whitney into the business. I tried to have Sharps Co. enter into the business more extensively as there were bright prospects in the future, but they could not see it, and declined. Sharps Co. commenced on a capital of $\$ 100,000$, increased it to $\$ 125,000$. The stockholders were paid back their full subscription of stock, about $\$ 200,000$ in dividends. Sharps was paid $\$ 1.00$ on each gun made; Penfield was paid about $\$ 1.25$ on each gun or 10 per cent on all sales. The Company could not agree on anything and sold out the whole plant for about $\$ 225,000$. It will be seen that the stockholders made a good thing out of the enterprise. This was all accomplished by the use and skill of my brain, as I had the full charge and control of the business. If the Company had taken my urgent advice they might today be in the position and place of the Pratt \& Whitney Co. One of my misfortunes in business all ny life was being engaged with men not mechanics, therefore not being able to comprehend the points coming up every day in business. Sharps Co. had the chance of taking several contracts which I worked up for them where the profits would have been over half a million. They could not see it and declined. When too late they saw their mistake.

\section{Note 2}

I introduced the first edging machine ever in use, on the Sharps gun in Windsor. The principle of this machine is now in general use. Also introduced the first machine for pressing on car wheels on a taper without splining or keying. This was done at Windsor. This principle has since been used in all Rail Road shops. Made a great mistake in not securing patents on both of the above. 


\section{Note 3}

Introduced the principle of lubricating the bullet for breach loading guns which was the salvation of breach loading guns. The guns were of no use before this. This was done in the winter of $1850 .^{1}$

\section{Note 4}

Before 1855 all annealing and case hardening was done with Char coal which was very expensive. About this time in Hartford I introduced the plan and furnaces for using hard coal which proved a great success and is now used everywhere for both case hardening and annealing. Many other improvements on gun work and machinery which I have made might be mentioned, but the above is sufficient.

1 See Appendix B. 


\section{APPENDIX B}

\section{THE JENNINGS GUN}

"Reminiscences of the first magazine rifle. Most important discovery by R. S. Lawrence of this city (Hartford, Conn.).Original use of lubricating material in fire arms."

A few days ago Mr. A. E. Brooks of this city (Hartford, Conn.) received a very curious and interesting magazine gun from New York, bearing the name of Ex-Superintendent R. S. Lawrence of the street department as the manufacturer. Conceiving that there must be a good story connected with the arm which was one of the first magazine guns ever made in this country, a reporter of The Post sought out Mr. Lawrence and learned the history of the gun. "The rifle which Mr. Brooks brought to my notice, with my name on it," said Ex-Superintendent Lawrence, "is one of a lot of 5,000 manufactured at Windsor, Vermont, by Robbins \& Lawrence, for Mr. Courtland C. Palmer of New York. This rifle was known as the Jennings gun. A portion of the lot was then called single loaders, and a portion repeating rifles, carrying twenty cliarges. The charge of powder was contained in the ball, consisting of twenty-two grains of powder only. With the repeating rifle I have often fired twenty shots within one minute, but not with any accuracy, for the reason that all breechloading guns up to this time used what is called the naked ball without any patch or lubricating material. The result in firing the gun was that the ball leaded the barrel, by building on, to such an extent that in firing twenty shots from a 50-100 calibre bore there would be a hole in the barrel less than 25-100."

"In the winter of 1850, while the guns were being manufactured at Windsor, Kossuth arrived in this country, as was 
supposed by many for the purpose of purchasing rifles. Mr. Palmer was anxious to sell his rifles, and telegraphed on to Windsor that Kossuth would purchase largely, if he could be shown that the Jennings rifle could be fired with sufficient accuracy to hit the size of a man ten times out of twenty-five at the distance of 500 yards. I answered by saying that it was impossible to do any such thing with the Jennings rifle. Another message was sent to Windsor to come to New York by the first train and bring the best gun and ammunition. I complied with the request. Mr. C. P. Dixon, Mr. Palmer's agent, had all things arranged for the trial at Astoria, L. I. I did my best in trying to accomplish the desired effect asked for, but not one of the twenty-five shots hit the target. Mr. Dixon said that we must make another trial the next day. I went to his hotel, more than ever disgusted with breech loading rifles, as all efforts had failed to make any accurate shooting with any naked balls. All gun men will understand this. My business was manufacturing rifles for the Government and for the Sharps Rifle Mfg. Co. Most of the night at the hotel was spent in trying to devise some way to remedy the trouble then existing with breech loading guns. At last the simple remedy came, which has proven the salvation of all breech loading guns."

"Early the next morning we started for the target field. I did not tell Mr. Dixon at first of my discovery. I simply told him that the trouble was all over with. If he would stop at the Fulton Market and purchase a small piece of tallow the rifle would do all that was required of it, but he had so little confidence in the gun that he would not be prevailed upon to purchase the tallow. I then thought that I would keep the new discovery to myself for awhile, but changed my mind on arriving on the target field, and tramped a mile on the ice to a farmhouse, and purchased a small piece of tallow. With the aid of a lathe in the cartridge shop on the ground, I turned out a number of grooves on the balls and filled them with tallow. I then went on to the stand and hit the target ten times in twenty shots. By this time I had the sights regulated 
and could hit the target about every shot, and finished after many shots with a clean gun barrel. This was the first instance of lubricating material being used in breech loading guns or any other guns. I challenge any dispute on this subject. This was the salvation of breech loading guns."

"At this time William E., a brother of Mr. Courtland C. Palmer, was in Paris with the Jennings gun. All parties were so interested with the success of the gun that Mr. Dixon, the agent, had two boxes of ammunition made up and sent by the next steamer to W. E. Palmer in Paris. In two weeks from the time of the trial in New York, the invention was known in Paris and applied to the French guns with the same success as was met with in the Jennings rifle. The same principle is used today in all breech loading guns. I came dircet from New York to Hartford, and informed the president of the Sharps Rifle Mfg. Co. of my new discovery and tried to induce the company to introduce the lubricating material in the Sharps Rifle, as this rifle then used the naked ball and was subject to the same very serious trouble as the Jennings. Mr. Sharps was called on and the use of the lubricating explained, but he ignored the whole matter, calling it a 'humbug.' I returned to Vermont somewhat disgusted. In less than one week the president of the Sharps Rifle Mfg. Co. wrote to Windsor to stop all work until Mr. Sharps and himself arrived, stating that Mr. Sharps had tried the lubricating material and found that it was indispensable, and that no more guns must go out before the change was made for lubrication. The Jennings rifles, of which a few had been made for samples, were in a crude state. Robbins \& Lawrence made new models and manufactured the 5,000 for Mr. Courtland C. Palmer. After this Mr. Tyler Henry, an old and first-class workman of Robbins \& Lawrence, made in New Haven great improvements on the Jennings rifle. After this it went into the hands of the Winchester Arms Company of New Haven. They made great improvements on the gun and called it the Winchester Repeating Rifle. It is the outcrop of the old Jennings rifle."'1

1 From the Hartford Evening Post, Tuesday, Feb. 25, 1890. 


\section{A PARTIAL BIBLIOGRAPHY ON TOOL BUILDING}

Smiles: Industrial Biography. Boston, 1864.

Smiles: Men of Invention and Industry. N. Y., 1885.

Smiles: Boulton and Watt. London, 1904.

Smiles: The Stephensons. London, 1904.

Smiles: Smeaton and Rennie. London, 1904.

Beck: Beiträge zur Geschichte des Maschinenbaues. Berlin, 1900.

Matschoss: Beiträge zur Geschichte der Technik und Industrie. Berlin, Bände I-V, 1909-1913.

Sargant: "Sir Samuel Bentham," in "Essays of a Birmingham Manufacturer." London, 1869.

Bentham, Mary S.: Memoirs of Brigadier-General Sir Samuel Bentham, in Papers and Practical Illustrations of Public Works. London, 1856.

Beamish : Life of Sir Mare Isambard Brunel. London, 1862.

Nasmyth: Autobiography of James Nasmyth, Edited by Smiles. London, 1883.

Holtzapifel: Turning and Mechanical Manipulation. London, 1847.

Buchanan: Millwork and other Machinery. London, 1841.

Perrigo: Modern American Lathe Practice. N. Y., 1907.

Perrigo: Change Gear Devices. N. Y., 1915.

Camus: Treatise on the Teeth of Wheels (English Translation).

London, 1837.

Willis : Principles of Mechanism. London, 1841.

Fairbairn : Mills and Millwork. London, 1863. 
Pole: Life of Sir William Fairbairn. London, 1877.

Memoir of John George Bodmer, in Transactions of the Institution of Civil Engineers, Vol. XXVIII. London, 1869.

Farey : Treatise on the Steam Engine. London, 1827.

Price: Fire and Thief-proof Depositories, and Locks and Keys. London, 1856.

Baker : Elements of Mechanism. London, 1858.

Bishop: History of American Manufactures. 3 Vols. Philadelphia, 1868.

Weeden: Economic and Social History of New England. 2 Vols. Boston, 1890.

Field: State of Rhode Island and Providence Plantations.

Goodrich: History of Pawtucket, R. I. Pawtucket, 1876.

Wilkinson: Memoir of the Wilkinson Family. Jacksonville, Ill., 1869.

Fitch: Report on Manufactures of Interchangeable Mechanism, in U. S. Census, 1880. Volume on "Manufactures."

Durfee: "Development of the Art of Interchangeable Construction in Mechanism," in Transactions of the American Society of Mechanical Engineers, Vol. XIV, p. 1225.

Olmstead: Memoir of Eli Whitney. New Haven, 1846.

Woodworth: American Tool Making and Interchangeable Manufacturing. N. Y., 1911.

Blake: History of Hamden, Conn. New Haven, 1888.

Blake: New Haven Colony Historical Papers, Vol. V. New Haven, 1894.

North: Memoir of Simeon North. Concord, 1913.

Washburn: Manufacturing and Mechanical Industries of Worcester. Philadelphia, 1889.

Iles: Leading American Inventors. N. Y., 1912.

Parton: Captains of Industry. Boston, 1891. 
Van Slyck: Representatives of New England. Boston, 1871.

Goddard: Eminent Engineers. N. Y., 1905.

Lathrop: The Brass Industry. Shelton, Conn., 1909.

Anderson: The Town and City of Waterbury. 3 Vols. New Haven, 1896.

Evans: The Young Millwright and Miller's Guide. Philadelphia, 1826.

Freedley: Philadelphia and its Manufactures. Philadelphia, 1858.

Cist: Cincinnati in 1851. Cincinnati, 1851.

Cist: Cincinnati in 1859. Cincinnati, 1859.

Porter: Engineering Reminiscences. N. Y., 1908.

Transactions of the Institution of Civil Engineers. London.

Transactions of the Institution of Mechanical Engineers. London.

Transactions of the American Society of Mechanical Engineers. Journal of the Franklin Institute. Philadelphia.

Files of "American Machinist," New York.

Files of "Machinery," New York.

Files of "Engineering Magazine," New York.

Files of "Cassier's Magazine," New York.

Files of "Engineering News," London.

Files of "Engineering," London.

Much of the data in the latter portions of this book is derived from private correspondence and personal interviews, and is, therefore, not available for reference. 
INDEX 



\section{INDEX}

Acme Wire Co.: 160.

Allen, Ethan: 226.

Allen, Walter: 264.

Alvord, J. D.: 192, 197.

American Brass Co.: 236.

American industries:

reasons for delayed development, 109-114;

influence of the cotton gin, 114.

American iron:

results of exportation to England, 110-113; early production, 115 .

American Pin Co.: 234.

American Screw Co.: 125, 198, 226 ; pointed screw, 126.

American Steel \& Wire Co.: 225226.

"American system" :

see Interchangeable manufacture.

American Tool Works: 269.

American Watch Co.:

interchangeable system, 144, 164.

American Wire Gauge: 205.

Ames Manufacturing Co.:

gun-making machinery, ete., 138, 140, 228-229.

Amoskeag Manufacturing Co.: 123, 124, 216-217, 253.

Andover, Mass.:

scythe mill, 117.

Angel, William G.: 126.

Ansonia Brass \& Copper Co.: 234.

Ansonia Clock Co.: 234.

Arkwright, Sir Richard: 6, 64, 121, $150,161$.

Armstrong, Sir William: 105.

Arnold, Asa :

partner of Pitcher, 124.
Arnold, Jeremiah O.: 125.

Arnold, Joseph :

brother of Jeremiah, 125.

Atwood, L. J.: 237.

Babbage, Charles:

calculating machine, 59.

Baldwin, Matthias:

Baldwin Locomotive Works, 256.

Bancroft, Edrard:

Bancroft \& Sellers, 247.

Barber-Coleman Co.: 274.

Bardons \& Oliver: 183, 265.

Barker, William:

partuer of Lodge, 269-270.

Barnes, B. F.: 274.

Barnes, W. F. \& John, Co. : 273.

Barnes Drill Co.: 274.

Baush Machine Tool Co.:

drilling machines, 230.

Bayley, O. W.: 217.

Beach, H. L.: 165.

Beach, H. B., \& Son: 165.

Beale, Oscar J.: accurate standards, 205.

Beckley, Elias : gun shop, 162.

Bellows, E. H.: 222.

Bement, Clarence S.: 255.

Bement, William B.: 217, 219, 249, 252-254;

estimate of, 255 ;

hammer, 255.

Bement \& Dougherty: 254.

Benient, Miles \& Co.: history of, 254.255.

Benedict, Aaron:

brass worker, 232.

Benedict \& Burnham: 234. 
Benedict \& Coe:

brass workers, 232.

Bentham Jeremy: 22, 25.

Bentham, Sir Samuel: 7, 22, 49, 89, 107 ;

work on Portsmouth block machinery, 8, 9, 18, 22, 26, 2s;

in Russia, 23, 24;

in British navy service, 24;

woodworking machinery, 24, 25;

planer, 51;

patent of 1793,38 ;

slide-rest, 6,38 ;

relations with Maudslay, 89.

Bessemer, Sir Henry: 96.

Besley, Charles II., \& Co.: 275.

Bibliography: 295.297.

Bickford, Henry: 272.

Bidwell, Jason A.: 198, 266.

Bilgram Machine Torks: gear cutting, 259.

Billings, Charles E.: 170, 174-17.j, 201.

Billings \& Spencer Co.: 175-176.

Blake, Eli Whitney: 160.

Blake, Philos: 160.

Blaisdell, P., \& Co.: 222.

Blanchard, Thomas: 220-221;

lathe for turning gun-stocks, 6 , 140, 142, 219, 220-221.

Blenkinsop:

Locomotives, 56.

Block machinery: see Portsmouth block machinery.

Bodmer, John George: 75-80; estimate of, 79 ;

diametral pitch, 70 note 7 ;

interchangeable manufacture, 76 , 131 ;

fire-arms, 76 ;

two patents, $77 \cdot 79$;

traveling crane, 77,80 ;

mill machinery, 76 .
Bond, George Mr.:

Rogers-Bond Comparator, 180 . 182.

Boring machines:

Smeaton's, 2, 13;

Wilkinson's, 3, 10, 11, 12, 13, 60 ; in 18 th century, 4 .

Boston, Mass.:

heary forge, 117.

Boston \& Worcester R. R.: 220.

Boulton, Matthew: 145;

on Wilkinson's boring machine, 3 ;

on Wilkinson, 145.

Boulton \& Watt: 3, 11, 46, 55;

relations with Wilkinson, 12, 13 .

Bow-string truss: 82.

Boye \& Emmes Machine Tool Co.: $268,2 \pi 1$.

Bramah, Joseph: 7, 8, 15, 107 ;

estimate of, 19, 20;

invention of slide-rest, 6, 36 ;

planer, 50;

hydraulic press, 18 ;

machine for numbering banknotes, 19 ;

woodworking machinery, 18, 19,

24;

other inventions, 18;

relations with Maudslay, 17, 19, 33, 34;

with Watt, 18;

with Clement, 19, 5s.

Bridgeport Brass Co.:

micrometer, 211-213.

Bridgeport Machine Tool Co.: 184.

British Snall Arms Commission: 138, 140, 141.

Brooker, Charles F.: 236.

Brown, David: 126, 202.

Brown, Capt. James S.: 124.

Brown, Joseph R.: 126, 202 ;

estimate of, 215;

" Universal', miller, 138 note 16, 196, 208-209; 
linear dividing engines, 202, 204. 205, 206;

vernier caliper, 203 ;

formed milling cutter, 206, 207 ;

improvements on turret serew machine, 207 ;

universal grinder, 214.

Brown, Moses:

textile industry, 120, 121.

Brown, Sylvanus: 124.

inventor of slide-rest, 6 ;

slide lathe, 120.

Brown Hoisting Machine Co.: 258.

Brown \& Elton:

wire and tubing, 233.

Brown \& Sharpe Manufacturing Co.: 125, Chapter XVI;

J. R. Bromne \& Sharpe, 202, 204; "Universal" miller, 138 note 16, 196, 208;

linear dividing engines, 206 ;

precision gear cutter, 206 ;

turret screw machines, 207-208;

limit gauges, 210;

micrometer caliper, 211-213;

cylindrical grinder, 213;

automatic gear cutters, 214.

Brunel, Sir Isambard K.: 32.

Brunel, Sir Mare I.: 7, 26, 27, 31, 49, 107;

slide-rest, 6 ;

inventions, 27 ;

Portsmouth block machinery, 8, 9, 22, 26, 27, 28.

Bryant, William L. :

chucking grinder, 200.

Buchanan :

English writer, 50.

Builders Iron Foundry or "High Street Furnace"': 125.

Bullard, E. P.: 183-184. vertical boring and turning mill, 184.185.

Bullard Machine Tool Co.: 184.
Burke, William A.: 253;

Amoskeag Manufacturing Co., 217 ;

Lowell Machine Shop, 217, 218.

Burleigh, Charles: rock drill, 228.

Burlingame, L. D.:

history of micrometer, 213.

Burton, James H.:

Enfield gun machinery, 140.

Calipers:

"Lord Chancellor," 45, 211;

vernier, 203;

micrometer, origin of, 211-213.

Campbell, A. C.: 237 .

Camus: 64 ;

"'The Teeth of Wheels,', 64-65, 68.

Carmichaels, of Dundee:

engine makers, 86.

Carron Iron Works: 2, 85.

Change-gear hox: 182.

Chase Rolling Mills Co.: 236.

"Chordal's Letters"': 261.

Cincinnati, Ohio:

tool building in, 266-267.

Cincinnati Bickford Tool Co.: 27.

Cincinnati Milling Machine Co.: 272.

Cincinnati Planer Co.: 271-272.

Cincinnati Serew \& Tap Co.: 272.

Clement, Joseph: 7, 8, 9, 57-58, 59, 99,107 ;

screw-thread practice, $10,19,57$, 58.59, 101;

gear practice, 68;

taps and dies, 10, 19, 58; lathes, 19,57 ;

planers, $19,50,52,54,59$;

relations with Bramah, 19, 5s; with Maudslay \& Field, 19, 46, 58.

Cleveland, Ohio: 183.

tool builders in, 261-266; 
first multi-spindle automatic screw machines, 265.

Cleveland Twist Drill Co.: 266.

Clock industry in Connecticut: 171 . 172.

Coe, Israel: 236.

Coe, Lyman: 234, 236.

Coe Brass Co.: 234.

Coes Wrench Co.: 226.

Colby, Gilbert A.: 254.

Collins Co.: axe makers, 169.

Colt, Samuel: 166-168; interchangeable system, 137, 168; Colt revolver, 166, 167; erection of Armory, 167, 168.

Colt Armory: 165, 166; erection of, 167,168 ; a "contract shop," 178 .

Conradson, Conrad N.: turret machine, 276.

Cook, Asa: 174.

Coombs, S. C.: 222.

Corliss Nachine Works: 126.

Cotton crop: growth of, 150-151.

Cotton gin: invention of, 131, 148 et seq; influence, 114, 131, 145, 149, 150 . 151, 161;

patent rights of, 151-158.

Cowie, Pierson: 221-222.

Cramp Ship Building Co.: 257.

Croft, James:

brass worker, 232.

Crompton, William: 114.

Cup-leather packing: 18.

Currier \& Snyder: 222.

Cushman, A. F.: 173.

Darby, Abraham, 3d:

first iron bridge, 15 .

Darling, Samuel :

graduating engine, 203, 204.
Darenport, James: textile machinery, 246.

Davenport, William S.: 214.

da Vinci, Leonardo: anticipation of modern tools, 6 , 36.

Daris, Charles: 269 .

Daris, .Jefferson:

on Thitney's steel-barreled muskets, 160 .

Daris \& Egan: 269.

D'Eichthal, Baron: partner of Bodmer, 75 .

De la Hire: gear ieeth, $63,64,67$.

DeLeeuw, A. L.: 273, 277.

Dennison, A. L.: American Watch Co., 144.

de Vaucanson, Jacques: milling cutter, 206.

Diametral pitch:

"Manchester pitch," 70 note 7; Bodmer, 80 .

Die forging: 137.

Dietz, Sehumacher \& Boye Co.: 268.

Dodge, Cyril: 126.

Dodge, Nehemiah : goldsmith, 126.

Dougherty, James: 254.

Draper Machine Tool Co.: 222.

Dresses, Henry : 271.

Dresses, Mueller \& Co.: 271.

Drilling machines:

in 18th century, 4.

Drop hanmer:

developed in America, 5, 143, 175.

Dwight, Dr. Timothy:

on Pawtucket, 121.

Eagle Screw Co.: 126.

Earle \& Williams: 219.

Eberhardt, Ulrich : 259.

Edgemoor Iron Co.: 249-250.

Egan, Thomas P.: 268, 269. 
Eminent Men of Science Living in 1807-1808. engraving by Walker, 20 .

Enfield Armory : 5, 96, 103;

Nasmyth on reorganization of, 140-141;

British Small Arus Commission, 138, 140 ;

gun-machinery, 138-141;

Robbins \& Lawrence, 191-192.

Epicyclic curve: 63, 67, 68.

Essex Machine Shop: 219.

Euler :

gearing, 64.

Evans, Oliver: 239-246;

conveyors for handling materials, 240-241, 246;

steam engine, 241-242, 245;

description of shop, 243;

steamboat, 242 ;

prediction of railways, 245;

"'Engineer's Guide," 242;

"Miller's Guide," 244.

Fairbairn, Sir Peter: 71, 74, 107.

Fairbairn, Sir William: 62, 107;

on machine tools, 10 ;

with George Rennie, 54, 71;

millwork, 71;

on "a good millwright," 72;

Fairbairn \& Lillie, 72-73, 77;

treatise on "Mills and Millwork,"

73 ;

iron ships, 73-74;

bridge building, 74 .

Fairbairn \& Co.: 268.

Fairfield, George A.: 170, 174, 176.

Fales \& Jenks Machine Co.: 125.

Farrell Foundry \& Machine Co.: 237.

Fay, J. A., \& Co.:

woodworking machinery, 229.230, 267.

Fay, J. A., \& Egan Co.: 230.

Fellows, E. R.: 199.
Fellows Gear Shaper Co.: 199.

Field, Joshua: 35, 89 ; relations with Maudslay, 8, 35, 90 ;

founder of Institution of Civil Engineers, 90.

Fire engine:

first in America, 116.

Fitch, John :

steamboat, 82 .

Fitch, Stephen:

horizontal turret, 197.

Fitchburg, Mass.: 219, 227-228.

Fitchburg Machine Works: 228;

Lo-swing lathe, 200.

Flagg, Samuel, \& Co.: 221, 222.

Flather Manufacturing Co.: 228.

Flax industry:

Murray's influence on, 57.

Foote-Burt Co.: 183;

drilling machines, 265.

Forehand \& Wadsworth: 226.

Forq, Nicholas:

planer, 50 .

Fosdick Machine Tool Co.: 271.

Fosdick \& Plucker: 271.

Fox, James: 7, 50, 52, 53, 54.

Fox \& Taylor: manufacturers of blocks, 28.

Fox, Henderson \& Co. : 192.

Francis, James B.:

hydraulic engineer, 218.

Franklin Machine Co.: 125.

Fulton, Robert: 150, 151, 161.

Gage, Warner \& Whitney: 218, 228.

Gang, William E.: 268, 271.

Gang \& Dietz: 271.

Gardner, Frederick M.:

disk grinding machines, 275 .

Gardner Machine Co.: 276.

Garvin Machine Co.: 127.

Gascoigne, William:

principle of micrometer, 211. 
Gay, Ira: 124, 216-217.

Gay, Zeba: 124, 217.

Gay \& Silver Co.: 195, 197, 217; planer, 53.

Gearing and Millwork: Chapter VI.

Geier, Frederick A.: 272-273.

"Genealogies"':

Early English Tool Builders, Fig. 5 ;

New England Gun-makers, Fig. 27 ;

Robbins \& Lawrence Shop, Fig. 37 ;

Worcester Tool Builders, Fig. 45; Naugatuck Brass Industry, Fig. 50.

Giddings \& Lewis Manufacturing Co.: 276.

Gisholt Machine Works: 276 .

Gleason Works: 183.

Globe Rolling Mill: 251.

Goddard, Benjamin: 225.

Gorham, Jabez: 127.

Gorham Manufacturing Co.: founded, 127.

Gould \& Eberhardt: 259.

Grant, John .J.: 214.

Gray, G. A., Co.: 273.

"'Great Eastern," The: 32.

"'Great Western," The: 32.

Great Western Railway: steamers, 93.

Greene, Nathaniel: cannon factory of, 118.

Greene, Mrs. Nathaniel: friend to Eli Whitney, 147; connection with cotton-gin, 148149.

Greene, Timothy: 119, 121.

Greenwood, Miles: 267.

Gridles, George O.: automatic lathes, 194, 200.

Grilley, Heury: founder of brass industry, 232 .
Grinder :

developed in America, 5;

Brown \& Sharpe's, 213-214;

dise, $275 \cdot 276$.

Hakerressel, Reinholdt: 183;

Acme automatic, 265.

Hamilton, Alexander: entertains Brunel, 8, 27.

Hamilton, Ohio: tool builders in, 273 .

Hampson, John: with Maudslay, 98.

Hanks, Alpheus and Truman: foundry, 165.

Harper's Ferry Arsenaì: 140, 143, 163 ; established, 136 ;

interchangeable equipment, 137 ; rifle, 160 .

Harrington \& Richardson: 226.

Hartford, Conn.: 127; manufactories of, 164, 165, 170; gun makers of, 16t, 166.

Hartford Machine Screw Co.: 170 , $174,176$.

Hartness, James: 194, 197-198, 266; designer of machine tools, 198; flat-turret lathe, 198 ;

Lo-swing lathe, 200.

Haskell, Co., The William H.: 124.

Iawkins, John Isaac: 69 ;

on early gear tooth practice, 65 . 68,70 .

Hayden, Hiram TV.: 234, 236.

Hendey Machine Co.: tool-room lathe, 182.

Henn, E. C.:

Acme allomatic, 265.

Herman, William: 271.

Hick, B., \& Son: 75.

High Street Furnace: 125.

Hildreth, S. E. : 222.

Hobbs, Alfred C.:

picks Bramah's lock, 16. 
Holmes, Hodgin :

cotton gin, 152, 154, 156, 157.

Holmes, Israel : 232, 233, 234, 236.

Holmes, Joseph : pioneer iron worker, 117.

Holmes \& Hotchkiss: 233.

Holmes, Booth \& Haydens: 234, 237.

Holtz, Frederick :

milling machine, 272.

Holtzapffel, Charles: 74, 99; on Roberts, 60-61;

plane surfaces, 100.

Hovey, P.:

partner of Pitcher, 124.

Howe, Elias:

sewing machine, 144.

Howe, Frederick W.: 195, 196, 209, 217 ;

milling machines, 138, 196, 208, 209 ;

profiling machine, 143, 191 ;

turret-head screw machine, 195-

196, 207;

turret lathe, 197, 199.

Howe, Hezekiah: 119.

Humphries:

suggests invention of large hammer, 93.

Hydraulic press:

invented by Bramah, 18, 34.

\section{Industrial conditions:}

new elements in 18th century, 1.

Ingersoll Milling Machine Co.: 274.

Institution of Civil Engineers:

founding of, 90 .

Interchangeable manufacture:

rise of, Chapter $\mathrm{XI}$;

developed in America, 5, 129 ;

defined, 128;

abroad, 138, 140 ;

in France, 129-131;

in Hartford, 164 ;

tools for, 142-143. clock, watch and sewing machine industries, 144;

Bodmer, 76 ;

Colt, 137, 168;

Enfield, 138, 141;

Simeon North, 131, 133, 135-136, 137, 162;

Robbins \& Lawrence, 191 ;

Eli Whitney, 131-133, 136.

International Machine Tool Co.: 275.

Involute gears: $63,61,67,68,207$. Iron bridge, the first: 15 .

Iron boats :

Wilkinson builds the first, 14;

Symington, 14, 82;

Brunel, 32 ;

Onions \& Sous, 14;

Jervons, 14 ;

at Horsley Works, 14;

"Great Eastern", and "Great

Western,', 32;

Fairbairn, 73-74.

Jefferson, Thomas: on interchangeable system in France, 129-131;

on Whitney, 135.

Jenks, Alfred:

textile machinery, 123, 246-247.

Jenks, Alvin:

cotton machinery, 124-125.

Jenks, Barton H.: 247.

Jenks, Eleazer :

spinning machinery, 123 .

Jenks, Joseph: 115-116, 125.

Jenks, Joseph, Jr.:

founder of Pawtucket, 118.

Jenks, Joseph, 3d: governor of Rhode Island Colony, 118.

Jenks, Capt. Stephen:

guns, 117 ;

nuts and screws, 124;

Jenks \& Sons, 125. 
Jennings gun :

origin of, $292-294$.

Jerome, Chauncey :

brass clocks, 144, 171-172, 233.

Jervons :

iron boat, 14.

Jewelry industry in Providence: 126-127.

Johnson, Charles: 237.

Johnson, Iver: 226.

Johnson, Judge : decision, Whitney vs. Fort, 155157.

Jones \& Lamson Machine Co.: 191, 193, 194, 197 ;

flat-turret lathe, 198-199;

Fay automatic lathe, 200.

Kaestner :

gearing, 64.

Kearney \& Trecker: 276.

Kempsmith, Frank: 264-265, 271.

Kempsmith Manufacturing Co.: 271, 276.

Kendall, N., \& Co.: 186, 189.

Key-seater: 61.

Lamson, Goodnow \& Yale: 192, 193.

Lamson Machine Co.: 198.

Landis Tool Co.: 259-260.

Lane \& Bodley: 267.

Lapointe, J. N.:

broaching machine, 183.

Lathes:

pole, 3,41 ;

engine, 4 ;

in 18 th century, 3,4 ;

automatic, 5, 176;

French rose engine, 6;

screw-cutting, 19, 35, 40, 119 .

120 ;

toolroom, 182;

Lo-swing, 200;

Bramah and Maudslay, 17;

Ramsden, 38;
Bentham, 38;

Maudslay, 40-42, 46;

Wilkinson, 119-120;

Blanchard, 140, 142-143;

Spencer's turret lathe, 176 ;

Fay automatic, 200;

Sellers, 250.

Lathe, Morse \& Co.: 222.

Lawrence, Richard S.: 188-189, 195;

profiling machine, 143 ;

master armorer, Sharps Works, 170, 194;

lubricated bullet, 194 ;

miller, 191, 194;

split palles, 194 ;

turret lathe, 197;

autobiography, 281-291.

Lawrence, Mass.: 127.

Lawrence Machine Shop: 219.

Lead screw : $35,36,38,39,40,41$, 43.

Le Blane:

interchangeable gun manufacture in France, 130.

Le Blond, R. K.: 271.

Lee-Metford rifle: 105 .

Leland, Henry M.: 214;

on J. R. Brown, 215.

Leonards: 116.

Libbey, C. L.: turret lathes, 275 .

Limit gauges : dereloped in America, 5.

Lincoln, Levi: 165, 171.

Lincoln Co., The: 165.

Lincoln, Charles L., \& Co.: 165.

Lincoln, George S., \& Co.: 137, 165.

Lincoln miller: 137, 165-166, 208.

Linear dividing engines: 206.

Lingren, W. F., \& Co.: 274.

Locomotives:

early inventions, 56;

Sharp, Roberts \& Co., 61.62;

Nasmyth, 93.

Lodge, William E.: 268.271. 
Lodge \& Davis: policy of, $270-271$.

Lodge \& Shipley Machine Tool Co.: 270.

Lowell, Mass.: 127; machine shops of, 218.

Lowell Machine Shop: 217, 218, 253.

Lucas Machine Tool Co.: 265.

McFarlan, Thomas: 268.

Macauley, Lord: on Eli Whitney, 161.

Machine tools: effect of modern, 1 ; erudity in 18th century, 3, 4; developments of, 4, 5, 63, 107 ;

Fairbairn on, 10;

Bramah and Mandslay, 34;

Whitworth, 99 ;

Greek or Gothic style, 63;

developed by cotton industry, 120 . Machine Tool Works: 255.

Machinist Tool Co.: 222.

Madison, Wis.: 276.

Manchester, N. H.: 123, 127; founding of, 217.

Manchester Locomotive Works: 217. Manchester pitch: 70 note 7,80 .

Manville, E. J.: 237.

Map of tool building industry: Fig. 56.

Marshall, Elijah D.: 254.

Marvel, C. M., \& Co.: 219.

Mason, William: 170, 173-174.

Massachusetts Arms Co.: 162.

Maudslay, Henry: 7, 8, Chapter IV; estimates of, $9,43,44,45,48,49$, 88 ;

taps and dies, 10, 42, 88;

Portsmouth block machinery, 8, 29, 35;

serew thread practice, 10, 40, 42, 88, 101;

cup-leather packing, 18, 34; the slide-rest, $6,35,36,38,40$, $43,49,143$;

screw-cutting lathe, $35,40,41$, $42,50,120$;

engine improvements, 43 ;

work on plane surfaces, 44, 45, $99,100$.

Maudslay \& Field: 8, 19, 35, 58, 98; influence on English tool builders, 46 ;

Moon's description of shop, 4648.

Maynard Rifle Co.: 161.

Mechanies Machine Co.: 274.

Merrick, S. V.:

introduces steam hammer into United States, 96, 257.

Merrimac Valley: textile works, 124, 127; shops of, 216-219.

Michigan Twist Drill \& Machine Co.: 266.

Midvale Steel Co.: 250.

Miles, Frederick B.: steam hammer, 255.

Mill, Anton: 272.

Miller, Patrick: 82.

Miller, Phineas: partner of Eli Whitney, 148.149, 153, 154.

Miller \& Whitney: 149, 152.

Miller, universal : origin of, 5, 138 note 16, 208-209.

Milling cutter, formed: 206-207, 208.

Milling machine:

Whitney, 142;

first in Hartford, 170, 194;

Lawrence, 191 ;

Lincoln, 137, 165-166, 208.

Millwork: Chapter VI;

Nasmyth on, 71 .

Milwaukee, Wis.:

tool builders in, 276-277.

Milwaukee Machine Tool Co.: 277.

Moen, Philip L.: 225. 
Montanus, Philip. 271.

Moody, Paul: expert in cotton machinery, 218.

Moore \& Colby: 252.

Morris, I. P., \& Co.: 257, 258.

Mueller, Oscar: 271.

Murdock : 55;

D-slide valves, 51 .

Murray, Matthew: 7, 54.57, 107; planer, 50, 51, 55, 57 ;

D-slide valve, 55 ;

steam heating, 56 ;

locomotires, 56 ;

influence on flax industry, 56.

Nashua Manufacturing Co.: 124.

Nasmyth, Alexander: 81, 82, 83 .

Nasmyth, James: $\bar{\tau}, 8$, Chapter VIII;

with Maudslay, 46, 48, 87, 88;

millwork, 71,88 ;

steam road earriage, 86 ;

milling machine, 89;

shaper, 92 ;

method of invention, 92;

steam hammer and other inceu.

tions, 93-96;

study of the moon, 97 ;

on interchangeable system of manufacture, 140-141.

Nasmyth \& Gaskell: 92 .

National Acme Manufacturing Co.: multi-spindle automatic lathe, 183 , 265.

Naugatuck Valley: Chapter XVIII; brass industry in, 231-238; pin machinery, 233.

New Britain, Conn.: hardware manufacture in, 171.

Nerrell, Stanford:

Franklin Machine Co.: 125.

New England industries:

early derelopment of, 109-110; cotton, 114;

iron, 116, 11i, 118.
New England Screw Co.: 126.

Newton \& Cox: 266.

Newton Machine Tool Works: 266.

New York: early steamboat trade, 127.

Niles, James and Jonathan: 251.

Niles \& Co.: 26i, 273.

Niles-Bement-Pond Co.: 179, 222, 255, 259, 273.

Niles Tool Works: 267, 273.

Norris, Henry M.: 272.

North Chelmsford Machine \& Supply Co.: 124.

North, Henry: 165.

North, Selah: filing jig, 142.

North, Simeon: 161-163; gun contracts, 131, 133, 134, 135, 137, 162, 163;

interchangeable system, 133-134, 136, 142, 145, 162.

Norton, Charles H.: precision grind. ing, 214, 224, 225.

Norton, F. B.: 224, 225.

Norton Company, The: 224, 225.

Norton Emery Wheel Co.: 224.

Norton Grinding Co.: 224, 225.

Norwalk Iron Works Co.: 184.

Oesterlien Mrachine Co.: 268.

Ohio Machine Tool Co.: 269.

Orr, Hugh: early mechanic, 116-117.

Orr, Robert: master armorer at Springfield, 117.

Otting \& Lauder: 268.

Owen, William: 271.

Palmer, Courtland C.: 190.

Palmer, Jean Laurent: screw caliper, 212, 213.

Palmer \& Capron: 127.

Parallel motion: 3 note 6 .

Parkhurst, E. G.: 182.

Parks, Edward H.: automatic gear cutters, 214. 
Pawtucket, R. I.:

manufacturing center, 118, 127 .

Dr. Dwight on, 121;

manufactures of, 118.125.

Peck: lifter for drop hammer, 143.

Pedrick \& Ayer: planer, 53.

Phelps \& Bickford: 220.

Phœnix Iron Works: 165.

Philadelphia, Pa.: tool builders in, Chapter XIX;

early textile machinery, 246.

Pin machinery: 233.

Pitcher, Larned:

Amoskeag Manufacturing Co.:

123 ;

Pitcher \& Brown, 124.

Pitkin, Henry and James F.: American lever watches, 164.

Pitkin, Col. Joseph: pioneer irou worker, 164.

Planer:

in 18 th century, 4 ;

developed in England, 4;

Bramah, 18;

Clement, 19, 52;

inventors of the, Chapter V;

early French, 50;

Roberts, 51;

Murray, 57;

Bodmer, 75, 76;

Sellers, 248.

Plane surfaces, scraping of:

Maudslay, 44, 45; Whitworth, 44, 98-101.

Plume \& Atwood: 234.

Plumier: French writer, 50.

Pond Machine Tool Co.: 222, 259.

Pope Manufacturing Co.: 170.

Portsmouth block machinery: influence on general manufacturing, 5 ;

work of Bentham and Brunel, 8 , $9,22,26,27,28$;

Maudslay's contribution to, 29, 35 ; description of, $29,30,31$;

Roberts, 60;

Maudslay and Bentham, 89;

approaches interchangeable sys-

tem, 131.

Potter \& Johnson: 183.

Pratt, Francis A.: 137, 170, 177 ;

Lincoln miller, 165, 191.

Pratt \& Whitney: 137, 178-183;

Interchangeable system, 179;

gun machinery and manufacture.

179-180, 182;

screw threads, 180-182;

tool-room lathe, 182;

thread-milling, 183;

workmen, 183;

turret screw machines, 207.

Precision gear cutter: 206.

Prentice, A. F.: 224.

Prentiss, F. F.: 266.

Priority in invention: 5 .

Pritchard, Benjamin : 216.

Profiling machine: inventors of, 143.

Providence, R. I.:

early cannon manufacture, 117 ;

trading center, 118;

textile industry, 123;

manufactures in, 118-126; jewelry

industry of, 126-127.

Providence Forge \& Nut Co.: 125.

Providence Tool Co.: 125;

turet serew machine built for, 207 ;

universal miller built for, 209 .

Providence \& Worcester Canal: 219 220.

Punching machine, Mandslay's: 43.

Putnam, John : 227-228.

Putnam, Salmon W.: 227-228.

Putnam Machine Co. Works: 200, 227-228.

Ramsden, Jesse: lathe, 38.

Randolph \& Clowes: 236 .

Reed, F. E.: 224. 
Reed \& Prentice Co.: 222.

Remington Arms Co.: 161.

Remington, E., \& Sons: 175.

Rennie, George: 54; planer, 50, 51 .

Rennie, Sir John: 54.

Rennie, John: millwright, 54.

Rhode Island Tool Co.: 125.

Richards, Charles B.: 173.

Richards, John: on Bodmer, 79.

Robbins \& Lawrence: Chapter XV; interchangeable system, 138;

turret lathe, 143, 197 ;

miller, 165, 191;

government contracts, 190 ;

Enfield rifle and gun machinery, 191-192;

cause of failure, 192 ;

successive owners of plant, 192194, 200.

Robbins, Kendall \& Lawrence: 189. 190.

Roberts, Richard: 7, 9, 59-60, 62, 107 ;

with Maudslay, 46, 60;

planer, 50, 51, 60;

locomotives, 61-62;

Sharp, Roberts \& Co.: 61, 62.

Robinson, Anthony: screw thread, 39.

Rockford, Ill.: tool builders in, 274 275.

Rockford Drilling Machine Co.: 274.

Rockford Iron Works: 274.

Rockford Lathe \& Tool Co.: 274.

Rockford Machine Tool Co.: 274.

Rockford Milling Machine Co.: 274.

Roemer: epicyclic curve, 63.

Rogers, William A.:

Rogers-Bond comparator, 1S0-182.

Root, Elisha K.: 168-169, 170.

influence on die forging, 137;

profiling machine, 143;

drop bammer, 143, 169;

Colt Armory, 169; machinery invented by, 169 ;

horizontal turret principle, 197.

Roper Repeating Arms Co.: 175.

St. Joseph Iron Co.: 253.

Savage Fire Arms Co.: 161.

Saxton: gear teeth, 66-67.

Schneider, M., and Nasmyth's steam hammer: 95-96.

Scituate, R. I.: Hope Furnace, 117.

Scorill Manufacturing Co.: 232.

Screw machines, multi-spindle automatic: 265.

Serew-thread practice:

Maudslay and Clement, 10, 19, 42, 58-59, 88 ;

Whitworth standardizes, 10, 101; early methods of screw cutting, 38-40;

Pratt \& Whitney, 180-182;

history of Sellers' or U. S. Standard, 249.

Sellers, Dr. Coleman : 251-252.

design of railway tools, 251; serew thread, U. S. Standard, 249.

Sellers, William: 247-251, 255;

inventions, 247-248;

planer, 248;

system of screw threads, 248-249;

bridge building machinery, 250:

great lathe, Washington Navy Yard, 250.

Sellers, William, \& Co.: 251, 252.

Sentinel Gas Appliance Co.: 160.

Shapers: developed in England, 4;

Brunel 's, 27 ;

Nasmyth's “Steel Arm," 92.

Sharp, Roberts \& Co.: 61, 62.

Sharpe, Lucian: 202;

American wire gauge, 205.

Sharps, Christian: breech loading rifle, 170, 192.

Sharps Rifle Works: 192, 194, 195.

Shaw, A. J.: 214.

Shepard, Lathe \& Co.: 222. 
Shipley, Murray: 270.

Slater, Samuel: 114, 119, 121;

Arkwright cotton machinery, 120, 121 ;

textile industry, 122;

Amoskeag Co., 216-217.

Slide-rest :

in 18th century, 4 ;

inventors of, 6 ;

early forms of, 6,36 ;

Bramah and Maudslay, 17;

Maudslay, 35, 36, 38, 40, 43, 49.

Sloan, Thomas J.: screw machine, 126.

Slocomb, J. T.: 214.

Slotter: 61 .

Smeaton, John: 2, 3;

boring machine, 2, 13;

cast iron gears, 64 .

Smith, George: 214.

Smith \& Mills: 270.

Smith \& Phelps : 234.

Smith \& Silk: 271.

Smith \& Wesson: 138.

Snyder, J. E., \& Son : 22.

Southwark Foundry \& Machine Co.: 173, 256-257.

Spencer, Christopher M.: 170, 175 177 ;

turret lathe, 143, 176;

board drop, 143;

silk-winding machine, 175 ;

repeating rifle, 175 .

Spencer Arms Co.: 177.

Spring: planer, 50, 53.

Springfield, Mass.: 230.

Springfield Armory: 103, 136, 138, 143, 163;

Blanchard's lathes, 142-143.

Springfeld Machine Tool Co.: 271.

Standard Tool Co.: 266.

Stannard, Monroe: with Pratt \& Whitney, 178.

Steam boats: early, 82 ;

Wilkinson's, 119.
Steam engine, Watt's: new element in industry, 1 ; problems in building, 1-3;

first built at Soho, 12 ;

Maudslay's improvements, 43 .

Steam hammer: 4;

Nasmyth's invention of, 93-96.

Steam heating apparatus: Murray, 56.

Steinle Turret Machine Co.: 277.

Stephenson, George: 6, 32, 56, 150.

Steptoe, John: 267-268.

Steptoe Co., The John: shapers and milling machines, 268.

Stone, Henry D.: 192, 193, 196; turret lathe, 143, 197.

Swasey, Ambrose: 183, 262, 263 ; dividing engine, 264.

Syme, Johnie: Nasmyth on, 84.

Symington, William: iron boat, 14, 82.

Taps and dies: developed in Eng. land, 4 ;

Maudslay's, 10, 42;

Clement's, 59.

Taylor, Frederick W.: high-speed tool steels, 250, 277.

Taylor \& Fenn Co.: 165.

Terry, Eli : clocks, 144, 171, 172.

Textile industries: Arkwright and Strutt, 53;

influence of Whitney's cotton gin, 114;

in New England, 114, 120, 123, 127 ;

Slater's influence on, 122.

Textile machinery:

Robert's spinning mule, etc., 61 ;

Bodmer, 77 ;

in New England, 114, 120-121;

Wilkinson, 122;

Alfred Jenks, 123.

Thomas, Seth: clocks, 144. 
Thomaston, Conn.: clock manufacture, 171.

Thurber, Isaac: Franklin Machine Co., 125.

Thurston, Horace: 214.

Tool builders: general estimate of early, $10 \bar{i}$; in Central New England, Chapter XVII;

Western, Chapter XX.

Tool building centers: 12 7 ; map of, Fig. 56.

Torry, Archie: Nasmyth's foreman, 91.

Towne, Henry R. : 257, 258.

Towne, John Henry: 256.257, 25\&: screw thread, U. S. Standard, 249.

Trareling crane, first: $\mathbf{7 7}, 80$.

Trerithick: steam road engine, 56 .

Turret lathes: 140 ;

early producers of, 143 ;

Spencer, 176 ;

Ноwе and Lawrence, 197 ;

Hartness' flat-turret, 198;

Warner \& Swasey, 26:2.

Turret serew machine, improvements on: 207.

Union Steel Serew Torks: 195, உ6.5, 266 .

Universal Radial Drill Co.: 273.

Wadsworth, Capt. Decius: on Whitney's interchangeable system, 134-135.

Waldo, Daniel: Hope Furnace, 137.

Wallace, William: 237.

Wallace \& Sons: 234.

Waltham Watch Works, see American Watch Co.

Warner, Worcester R.: 183, 262, 263.

Warner \& Swasey Co.: 261.265; building of astronomical instruments, 263-264.
Washburn, Ichabod: American Steel

\& Wire Co., 225, 226.

Washburn \& Moen Co.: 225.

Waterbury Brass Co.: 234, 237.

Waterbury Button Co.: 234.

Waterbury Clock \& Wateh Co.: 234. Waters, Asa : 226.

Waston, William: Nasmyth on, 84 . Watt, James: 3, 6, 82, 83, 150, 161; invention of steam engine, 1, 2, 145 ;

parallel motion, 3 note 6 ;

dependence on Tilkinson's boring machine, 3 ;

opposed by Bramah, 18 .

Teed Serring Machine Co.: 170 , $174,175$.

Weeden, W. N.: 237.

Wheeler, William A.: 221.

Wheeler \& Wilson: 192.

Whipple, Cullen: 126.

Whitcomb, Carter, Co.: 222.

Whiteomb-Blaisdell Machine Tool Co. : 222.

Thite, Zebulon: J. S. White \& Co., 122.

White Sewing Machine Co.: 193, 266.

Whitman-Barnes Co.: 266.

Whitney, Amos: 137, 170, 177, 219.

Whitney, Baxter D.: 177, 230.

Whitney, Eli: 6, 146-147, 161, 177; interchangeable s5stem, 76, 132133, 134-135, 136, 145, 146, I58159 ;

cotton gin, 114, 131, 145, 148-158; U. S. contract of 1798, 131-132, 158, 159 ;

Whitneyville plant, 132, 162, 158, 160 ;

method of manufacture, 158-159;

milling machine, 142 ;

Miller \& Whitney, 149. 


\section{INDEX}

Whitney, Eli, Jr.: contract for "Harper's Ferry"' rifle, 160; steel-barreled muskets, 160, 162.

Whitney Arms Co.: 160-161; first Colt revolvers made by, 167 .

Whitworth, Joseph: 7, 8, 9, 93; Chapter IX;

screw-thread practice, $10,59,101$, 102 note 4;

manufacture of plane surfaces, 44 , 45, 98-101;

with Maudslay, 46, 98;

shaper and improvements in machine tools, 99;

improved methods of measurement, 101 ;

ordnance and armor, 104-105;

on American automatic machinery, 102-104;

William Armstrong, 105.

Wilcox \& Gibbs Sewing Machines: 208, 210, 213.

Wilkinson, Abraham: 119.

Wilkinson, Daniel: 119, 122.

Wilkinson, David: 123, 124, 125; patent on slide-rest, 6 ;

steamboat, 119 ;

slide lathe, 119-120;

textile machinery, 122;

nail manufacture, 122.

Wilkinson, Isaac: 119, 125.

Wilkinson, John: 2, 8, 11, 15;

boring machine, $3,10,11,12,13$, 60 ;

first iron boat, 14;

first iron bridge, 15 ;

relations with Boulton \& Watt, $12,13$.
Wilkinson, Ozeal: 118-119, 121, 122.

Wilkinson, William: 119, 121.

Willimantic Linen Co.: 175, 178.

Willis, Robert: 69 note 5 ;

gear teeth, 63, 64, 69-70.

Wilmot, S. R.: micrometer, 212.

Winchendon, Mass.: woodworking machinery, 230.

Winchester Repeating Arms Co.: $160,174$.

Windsor, Vt.: 127, 186.

Windsor Machine Co.: Gridley automatic lathes, 194, 200.

Windsor Manufacturing Co.: 193.

Woleott, Oliver: 132.

Wolcottville Brass Co.: 233-234.

Wood, Light \& Co.: 222.

Woodruff \& Beach: 165.

Woodward \& Powell Planer Co.: 224.

Woodworking machinery: Bramah, 18, 19, 24;

Bentham, 24, 25;

Brunel, 31;

in Massachusetts, 229.

Worcester, Mass.: 127 ;

tool builders in, 219.226; early textile shops of, 220 ;

gun makers in, 226.

Worm-geared tilting pouring-ladle, Nasmyth's : 91-92.

Worsley, S. L. : automatic serew machine, 208.

Wright, Sylvester : 200, 228.

Yale \& Towne Manufacturing Co.: 258. 



\section{DUE DATE}

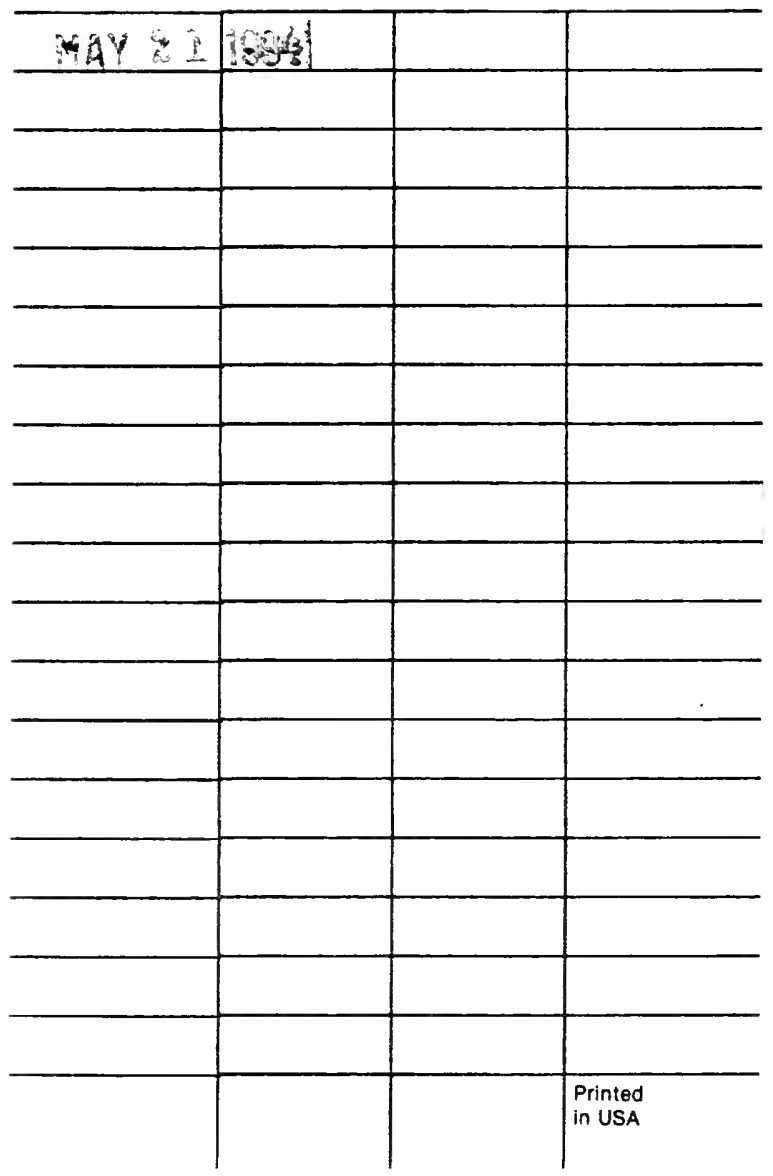

Waltham, mass. MAR. 1964 

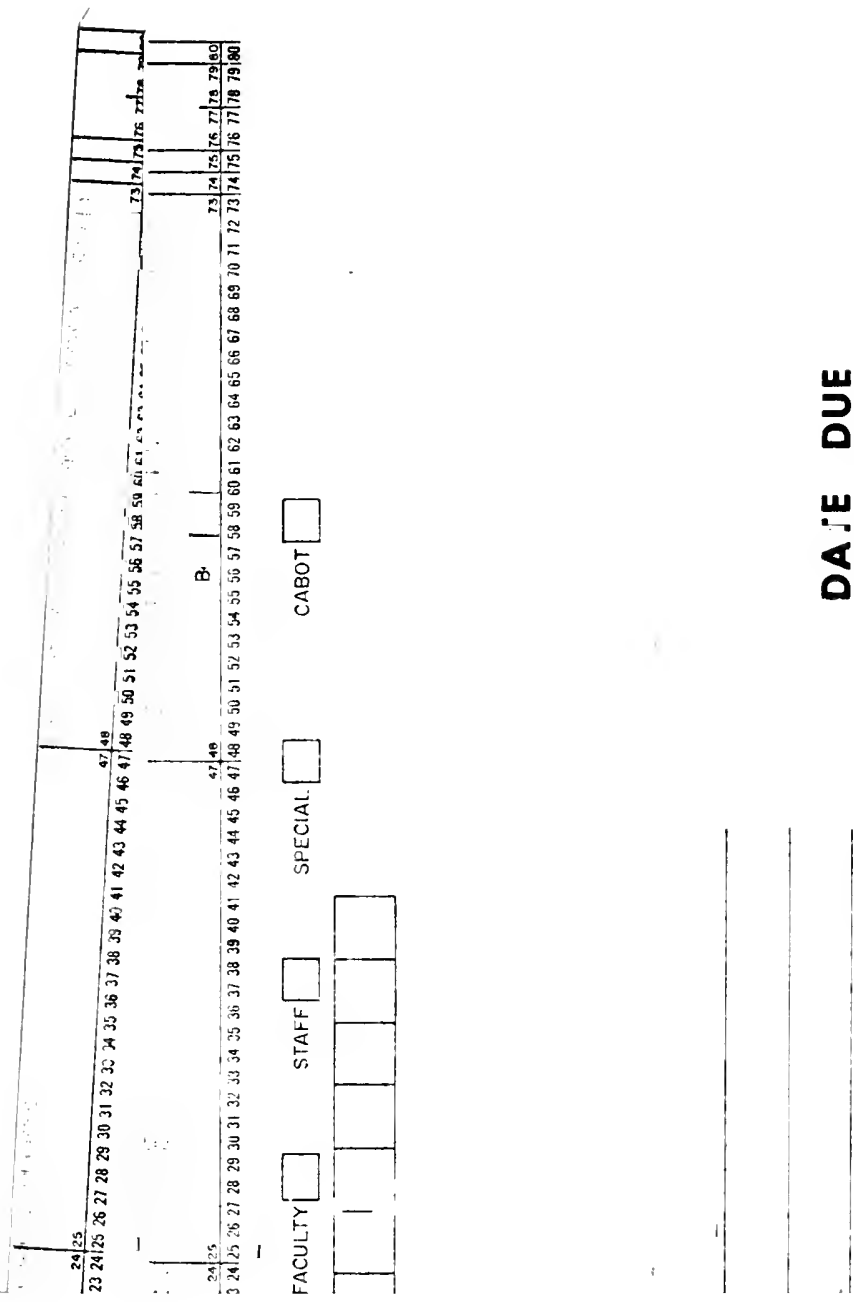

$\frac{\square}{5}$

1

1

$\underbrace{\square}_{\substack{\frac{1}{0} \\ \frac{1}{0} \\ \frac{1}{\omega}}}$

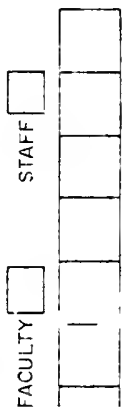

$\mid \begin{aligned} & 0 \\ & 0 \\ & 0 \\ & 0 \\ & \frac{2}{N}\end{aligned}$

T J1185

R6

1926

Roe, Josesh Wictinain, $1871-$

English and American tool builders, by Joseph wickham Roe. New York, London, McGraw-Hill, 1926.

xv, 315 o. illus., 24 cm. 


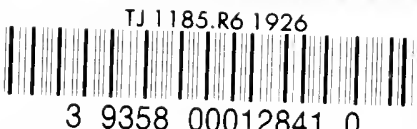

